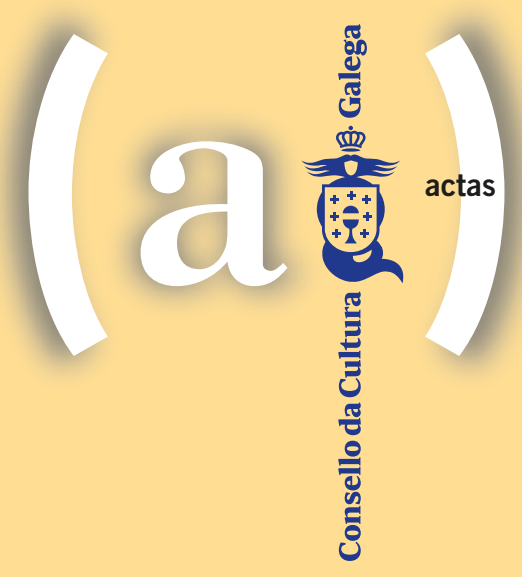

CARLOS NÁRDIZ ORTIZ COORDINADOR

\title{
A POSTA EN VALOR DO PATRIMONIO CULTURAL DOS RÍOS: GALICIA E OUTROS EXEMPLOS
}





\section{A POSTA EN VALOR DO PATRIMONIO CULTURAL DOS RÍOS: GALICIA E OUTROS EXEMPLOS}




\section{Edita}

(C) CONSELLO DA CULTURA GALEGA, 2020

Pazo de Raxoi $\cdot 2^{0}$ andar - Praza do Obradoiro

15705 - Santiago de Compostela

T 981957202 · F 981957205

corre0@consellodacultura.gal

www.consellodacultura.gal

\section{Imaxe da cuberta}

Ponte Maceira sobre o río Tambre

Foto de Carlos Nárdiz

Maquetación

Grafisant, S.L.

Depósito legal: C 10-2021

ISBN 978-84-17802-27-1

DOI: 10.17075/pvpcr.2021 
CARLOS NÁRDIZ ORTIZ

COORDINADOR

\section{A POSTA EN VALOR DO PATRIMONIO CULTURAL DOS RÍOS: GALICIA E OUTROS EXEMPLOS}

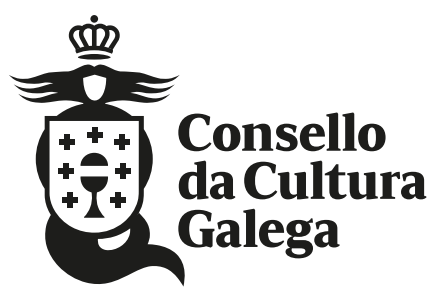


Presentacións 


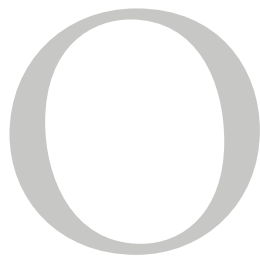

$s$ ríos forman parte do patrimonio natural de Galicia, sen eles non se recońecería esta terra, a pesar das transformacións que tiveron, especialmente no século xx, coa construción de presas e encoros ou coa propia canalización en áreas urbanas e periurbanas. Asociado aos ríos existe un patrimonio cultural de muíños, batáns, ferrarías, lavadoiros, pesqueiras, presas e represas, canles laterais, pontellas, pontes históricas, embarcadoiros para o paso das barcas e, nas súas marxes, fábricas para o aproveitamento dos recursos da auga, fortificacións para a defensa dos pasos naturais, como parte dun patrimonio cultural non sempre recoñecido.

A lectura ecolóxica do territorio a partir dos espazos naturais e a súa conexión por corredores fluviais e infraestruturas verdes introduciu unha nova dimensión ao patrimonio cultural dos ríos, onde experiencias en España se unen a outros exemplos a nivel internacional dos ríos americanos e europeos. Trasladar estas experiencias desde a escala local e rexional, tomando como referencia os ríos en Galicia, parece necesario para a protección e rehabilitación deste patrimonio cultural. A propia Administración galega — como vimos no Seminario Obras Públicas e Patrimonio Cultural realizado en 2014- dispón dun inventario do patrimonio cultural dos ríos (máis por consideracións hidráulicas que patrimoniais), que non é suficientemente coñecido e do que o Consello da Cultura Galega se fai eco nesta publicación, ao tratarse dun patrimonio ameazado.

\section{Carlos Nárdiz Ortiz}

Coordinador das Xornadas

Membro da Sección de Patrimonio e Bens Culturais (CCG) 



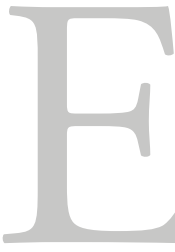

ntre as diferentes actividades que se desenvolven no Consello da Cultura Galega, organizadas pola Sección de Patrimonio e Bens Culturais, encóntranse distintas xornadas que, ao longo dos últimos anos, serven de espazo de divulgación, discusión e reflexión de diferentes temáticas ao redor do noso patrimonio cultural desde un concepto holístico que o entenden como identidade, pero tamén como herdanza, tanto polo recibido do pasado coma polo legado cara ao futuro. A súa comprensión e conservación son claves para a nosa construción cultural como pobo galego. Neste sentido, a realización deste tipo de actividades encamíńase tanto a ter unha constante actualización do que en Galicia se está facendo en materia de patrimonio, prestando atención aos debates teóricoprácticos que rexen a praxe diaria da xestión do patrimonio, coma á discusión crítica derredor de temáticas patrimoniais que son de plena actualidade e á consecuente reflexión que na propia sección tentamos recoller e incorporar á nosa práctica dentro do Consello da Cultura Galega, co fin de atender ás demandas que existen na nosa comunidade neste campo.

No ano 2014, desenvolveuse no CCG un seminario titulado «Obras públicas e o patrimonio cultural» no que tivo lugar o relatorio «As obras hidráulicas en Galicia e o patrimonio cultural», da man de Francisco Alonso e Ignacio Ardá Freire. Nesta intervención, púxose de manifesto o importante patrimonio cultural que existe en Galicia, «o país dos mil ríos» (Ripalda, 2010), ao redor dunha riquísima rede hidráulica que artella o territorio e, con el, a localización das poboacións, a explotación dos recursos hídricos, a propia economía e o seu uso como fronteira de diferentes unidades territoriais, a paisaxe e, como consecuencia de todo o mencionado, a xeración dun inxente patrimonio que vai desde os muínos e as presas até as pontes e fortalezas. A exposición amosaba, por unha banda, un traballo de inventariado xa feito (neste caso por parte de Augas de Galicia e da Confederación Hidrográfica do Miño-Sil), pero ao mesmo tempo descoñecido para moitos 
dos xestores patrimoniais que traballan neste ámbito, e, por outra, o precario estado de conservación de moitos destes elementos patrimoniais e da paisaxe que axudaron a construír, por mor de diferentes factores, entre eles o despoboamento dos espazos rurais e a mudanza dos sistemas de explotación do medio e das economías tradicionais en Galicia. Esta perda de uso levou a un abandono deste patrimonio, logo á ruína e finalmente ao esquecemento, á perda da memoria de todo o construído e, daquela, tamén dos saberes e oficios que están detrás desas construcións. Naquel momento, recollemos a idea de facer unha xornada monográfica dedicada a este tema que acabou materializándose nos días 6 e 7 de novembro de 2018 e cuxas intervencións se publican agora en forma de texto.

No deseño destas xornadas tratouse de ter en conta, dunha parte, a heteroxeneidade deste patrimonio, tanto desde o punto de vista tipolóxico coma funcional ou cronolóxico, incorporando unha serie de relatorios que mostrasen diferentes realidades patrimoniais ao longo do territorio galego. Trouxéronse, ademais, outros exemplos do territorio peninsular e internacional (como o caso do río Tyne, na área metropolitana de Newcastle) que tiñan como obxectivo mostrar, contrastar e posteriormente discutir as diferentes estratexias adoptadas noutros casos tanto para a documentación deste tipo de patrimonio coma para a súa recuperación e posta en valor. $\mathrm{O}$ obxectivo era sermos capaces de pechar as xornadas cunha mesa de reflexión sobre a xestión que se está facendo en Galicia do patrimonio cultural dos ríos, identificando as ferramentas de xestión que si están funcionado e as posibles eivas, e desenvolvendo propostas que recollan aqueles aspectos que poidan contribuír a mellorar esta xestión. A frutífera discusión que tivo lugar durante estas xornadas, accesible grazas aos diferentes audiovisuais que están á disposición pública na mediateca do Consello da Cultura Galega, e a demanda por parte do alto número de asistentes de desenvolvermos unha publicación sobre os temas tratados leváronnos a facer un esforzo neste sentido, o cal ve agora a luz nestes textos.

\section{Rebeca Blanco-Rotea}

Coordinadora da Sección de Patrimonio e Bens Culturais (CCG) 



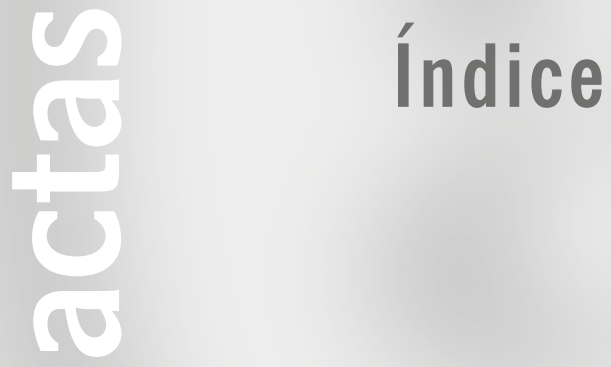




\section{I PARTE. O PATRIMONIO CULTURAL E A PAISAXE DOS RÍOS}

17 El paisaje cultural de los ríos Carlos Nárdiz Ortiz

33 El paisaje y el patrimonio cultural de las riberas del Tajo en Extremadura María del Mar Lozano Bartolozzi

55 El patrimonio cultural de los ríos en las Directrices de Ordenación del Territorio de Valladolid y Segovia

Juan Luis de las Rivas Sanz

71 Estrategias de recuperación del patrimonio industrial del río Tyne en el área metropolitana de Newcastle (Reino Unido). Aproximaciones conjuntas al patrimonio cultural y natural Rosa Teira

89 II PARTE. A POSTA EN VALOR DO PATRIMONIO CULTURAL DOS RÍOS EN GALICIA

91 Inventario e estudo de infraestruturas tradicionais de carácter hidráulico-industrial de Galicia

Roberto Arias Sánchez, Olalla Mosquera Barreiro, Laura

M. Garrido Fernández e Jorge Núñez Ares

113 O patrimonio vencellado aos ríos e mananciais de Galicia Xoán Nóvoa Rodríguez

135 Un río que nace frade e morre bispo ou nace bispo e morre frade. Apuntamentos sobre o patrimonio cultural hidráulico galego

Francisco Alonso Toucido

147 A xestión do patrimonio cultural dos ríos de Galicia. Protección e conservación

Teresa Nieto

163 As fortificacións modernas do Miño. Reflexións sobre diferentes estratexias para a súa posta en valor Rebeca Blanco-Rotea 

I PARTE.

O PATRIMONIO CULTURAL

E A PAISAXE DOS Ríos 

EL PAISAJE CULTURAL

DE LOS RIOS

Carlos Nárdiz Ortiz

Dr. ingeniero de Caminos, Canales y Puertos

DOI: 10.17075/pvpcr.2021.001 

La dimensión cultural del paisaje está recogida en el Convenio Europeo del Paisaje, que la define como «cualquier parte del territorio tal y como lo percibe la población, cuyo carácter sea el resultado de la acción y la interacción de factores naturales y/o humanos", es decir, como una realidad integrada de naturaleza y cultura. La noción de paisaje cultural ha ido creciendo en el tiempo a partir de este convenio y tenía antecedentes en la propia Convención sobre la Protección del Patrimonio Mundial, Cultura y Natural de las Naciones Unidas, de 1972, que definía los lugares como obras del ser humano u otros conjuntos del ser humano y la naturaleza ${ }^{1}$.

Las formas tradicionales de los asentamientos humanos, de utilización de la tierra y el mar, representativas de una cultura (o de varias culturas) o de la intervención del ser humano sobre el medio, son uno de los criterios que establece la UNESCO para declarar un bien Patrimonio de la Humanidad (véase la Guía para la elaboración de proyectos de inscripción en la lista del patrimonio mundial, 2. ${ }^{\mathrm{a}}$ ed., 2011). A las categorías de monumento, jardín histórico, conjunto histórico, sitio histórico o zona arqueológica, que recogía por ejemplo la Ley del Patrimonio Histórico Español, de 1985, para la declaración de Bien de Interés Cultural (BIC), se ha ido uniendo, con las legislaciones autonómicas (como la última de Galicia de 2016), la categoría de paisaje cultural. El propio Consejo de Europa elaboró, en el año 2000, un Convenio sobre el Paisaje Cultural, resultado de la acción de factores naturales y culturales, como categoría que debería dirigir las políticas de protección del paisaje.

En España, el Instituto del Patrimonio Cultural ha elaborado un Plan Nacional de Paisajes Culturales cuya escala territorial implica la integración de actividades agrícolas, ganaderas, forestales, industriales, comerciales, e incluso sociales y religiosas, como paisajes definidos, creados y diseñados intencionadamente por el ser humano y que han ido modificándose con el paso del tiempo, pero en los que en algunos casos todavía es posible identificar su autenticidad e integridad para convertirse en Bienes de Interés Cultural (lo que implica una protección y una gestión) e incluso en Patrimonio de la Humanidad².

1 Véase una reflexión sobre los paisajes culturales de Aguiló, Miguel / Ramón de la Mata (dirs.) (2005): Paisajes culturales, Colegio de Ingenieros de Caminos, Canales y Puertos.

2 Cruz Pérez, Linarejo (coord.) (2015): 100 paisajes culturales en España, Comisión de Seguimiento del Plan Nacional de Paisaje Cultural, Ministerio de Educación, Cultura y Deporte. 
La noción de paisaje cultural tiene, en las intervenciones realizadas en los ríos, al menos en las etapas preindustriales (pero que hoy podemos extender a la etapa industrial en el siglo XIX, e incluso al siglo XX), una de sus manifestaciones. Las actividades agrícolas, industriales y urbanas relacionadas con el aprovechamiento del agua han determinado la construcción de presas, canales de derivación, fábricas hidráulicas, puentes, muelles para la navegación o el cruce del río, lavaderos y rampas cuyas ruinas, en muchos casos, forman parte de un patrimonio cultural material, que se une al inmaterial (relacionado con usos y costumbres hoy en gran parte desaparecidos), en el que se reconoce también el paisaje de los ríos. Las relaciones, por otra parte, de los asentamientos desde la Prehistoria (como el santuario prehistórico del arte rupestre del valle del Tajo) o los asentamientos históricos desde los castros a los núcleos y ciudades que se establecieron en los bordes de los ríos, y que han conservado sus relaciones históricas con las márgenes, muestran la existencia de un patrimonio cultural (por formar parte de la memoria histórica de las relaciones con los ríos) que caracteriza también el paisaje de los ríos.

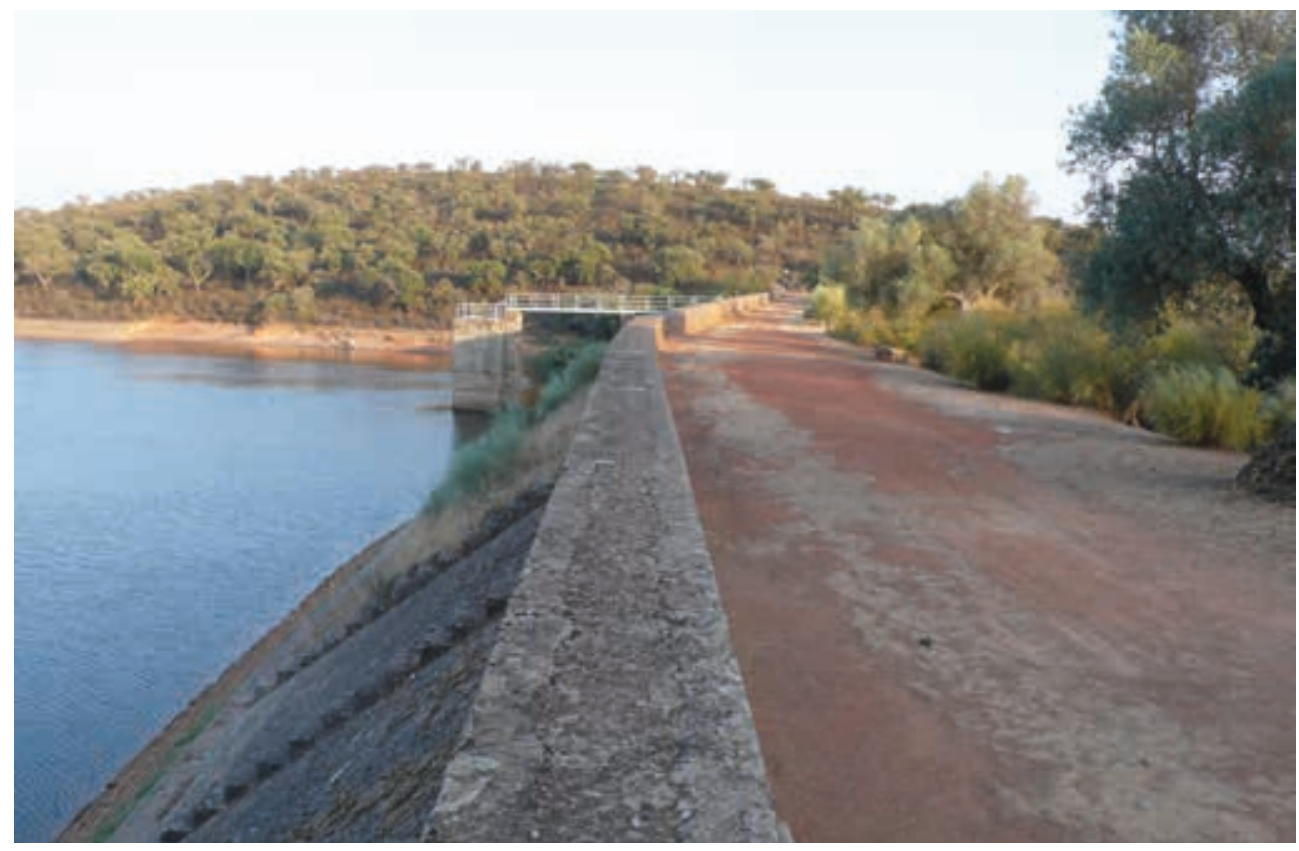

1. Presa de Cornalvo, en Mérida. Foto C. N. 
Comenzaremos por los azudes, represas y presas para embalsar el agua para el abastecimiento y el riego, o para desviarla para los canales de riego, de navegación, o para las fábricas hidráulicas. Los romanos, que conocían muy bien la fuerza de las aguas (que sufrirán directamente en la construcción de los puentes), solamente se atrevían a construir presas en los ríos secundarios, afluentes de los principales. Algunas presas, como las de Proserpina y Cornalvo para el abastecimiento de Mérida (y también para el riego), todavía se conservan en buen estado de funcionamiento, constituyendo referencias del paisaje en torno a las ciudades que han acondicionado las márgenes de los ríos y embalses. Con otras, como las de Alcantarilla y Consuegra, solo podemos relacionarnos a través de las ruinas ${ }^{3}$.

El Medievo se caracterizó por la construcción de numerosos azudes para el riego de la España seca, como los azudes del Turia, próximos a Valencia; los del río Segura, próximos a Murcia, con pequeños embalses de derivación de las aguas de los ríos (rebasables en coronación) que se extenderían en los siglos siguientes a los ríos pirenaicos y cantábricos; como los proyectados a finales del siglo XVI por Pedro Bernardo Villarreal de Bérriz, en el País Vasco, al servicio de molinos y herrerías. Es en esta época (finales del XVI y comienzos del XVII) cuando en España se construyeron presas, como la de Tibi o Elche (la primera en ruinas y la segunda en funcionamiento) con planta curva, que llegaron a ser las más altas del mundo.

Durante el siglo XVIII, las presas para el riego, como la de Puentes, construida a finales de este siglo, con sus $50 \mathrm{~m}$ de alto (la más alta del mundo en aquel entonces) y arruinada a comienzos del siglo posterior por sus problemas de cimentación, se complementaron con las que derivaban el agua para los canales de navegación, como la de Pignateli, en el Bocal, para el canal imperial de Aragón (todavía en funcionamiento, junto a la Casa de Compuertas), en donde se encuentran las ruinas de la presa de El Gasco, para el canal de Guadarrama, que partía desde el norte de Madrid al puerto de Sevilla y que formó parte del sueño ilustrado relacionado con el agua que se produjo en este siglo.

3 Para información sobre las presas históricas españolas hasta el siglo XIX, véase Smith, Norman A. F. (1970): The Heritage of Spanish Dams, Colegio de Ingenieros de Caminos, Canales y Puertos (edición de 1992); y Fernández Ordóñez, José A. (dir.) (1984): Catálogo de noventa presas y azudes españoles anteriores a 1900, CEHOPU. 


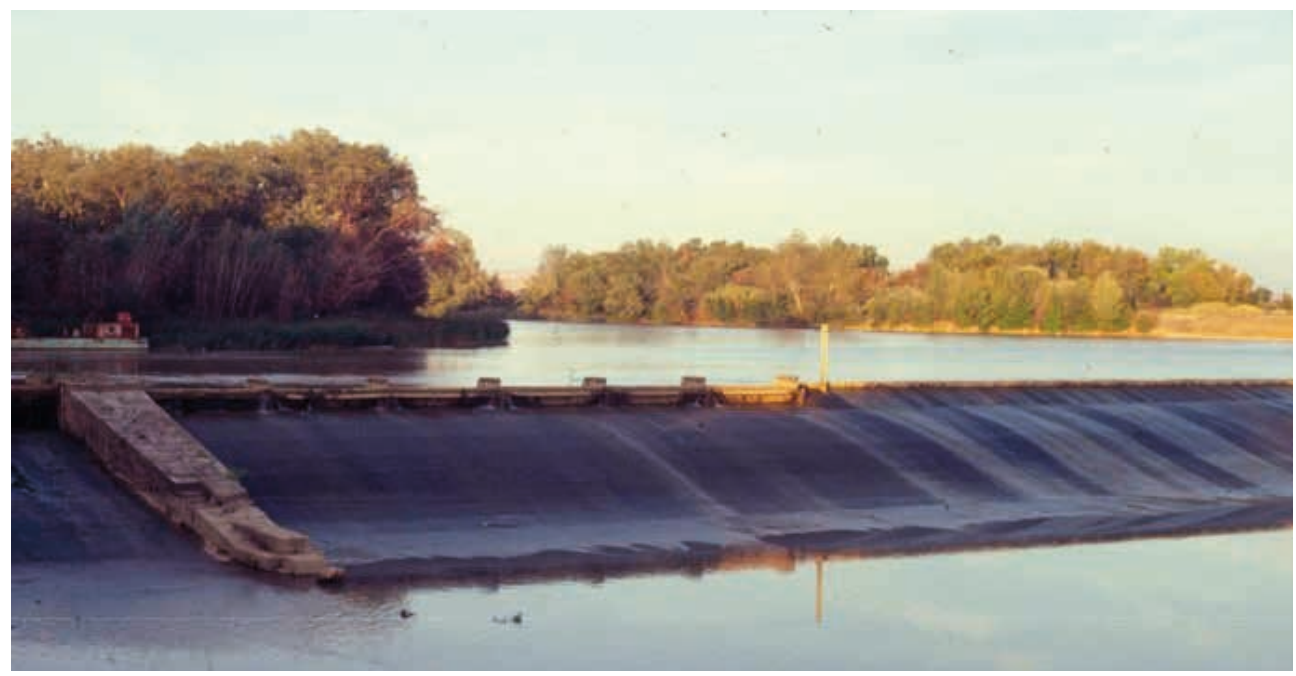

2. Presa de Pignateli, en el Bocal. Foto C. N.

En el siglo posterior, a las presas de la España seca para el riego (a las que también hay que añadir otras tierras como Extremadura), se unirán las presas para el abastecimiento de agua, empezando por la presa del Pontón de la Oliva, a mediados del siglo XIX, para el canal de Isabel II, que se arruinó poco después por problemas de filtración y fue sustituida, a finales del siglo XIX, por la presa del Villar, destinada al abastecimiento de Madrid.

No hay duda de que estos azudes y presas forman parte del patrimonio cultural de los ríos, aunque su valoración desde el punto de vista patrimonial y paisajístico no se producirá hasta épocas recientes, en el caso de España, hasta la década de 1980.

Los canales de derivación desde los azudes o represas van asociados a las fábricas hidráulicas, que a su vez disponían de canales de desagüe para reintegrar el agua al curso fluvial. Aunque originariamente se trataba de canales de madera, los que se conservan son de piedra, con sección rectangular, construidos con sillería o mampostería. El volumen del agua que entraba en el canal era regulado mediante las tomas, con compuertas de madera o metálicas. Los canales de mayor longitud disponían además de aliviaderos para regular el agua circulante. Al final del canal se solía disponer de una cámara de descarga para dirigir el agua, con mayor presión hacia los rodetes en el caso de los molinos. 
La transformación de la energía del agua en trabajo mecánico mediante ruedas y engranajes al servicio de molinos, ferrerías, batanes y serrerías, etc. formaba parte de técnicas que venían desde la Antigüedad y que se generalizaron en el mundo medieval, con legislaciones específicas como el Fuero Juzgo (siglo VII). Por su parte, los árabes las aplicaron en las aceñas y norias que construyeron en los ríos más caudalosos y las convirtieron en la base de su civilización. Los conocimientos hidráulicos y mecánicos fueron sistematizados supuestamente por Juanelo Turriano en Veintiún libros de los ingenios y las máquinas. El propio Leonardo da Vinci había investigado a finales del siglo XV sobre el rendimiento de las máquinas hidráulicas. Hoy, estos ingenios y máquinas forman parte de lo que Caro Baroja llamaba la tecnología popular, asimilándola a la tecnología previa a la Revolución Industrial ${ }^{4}$.

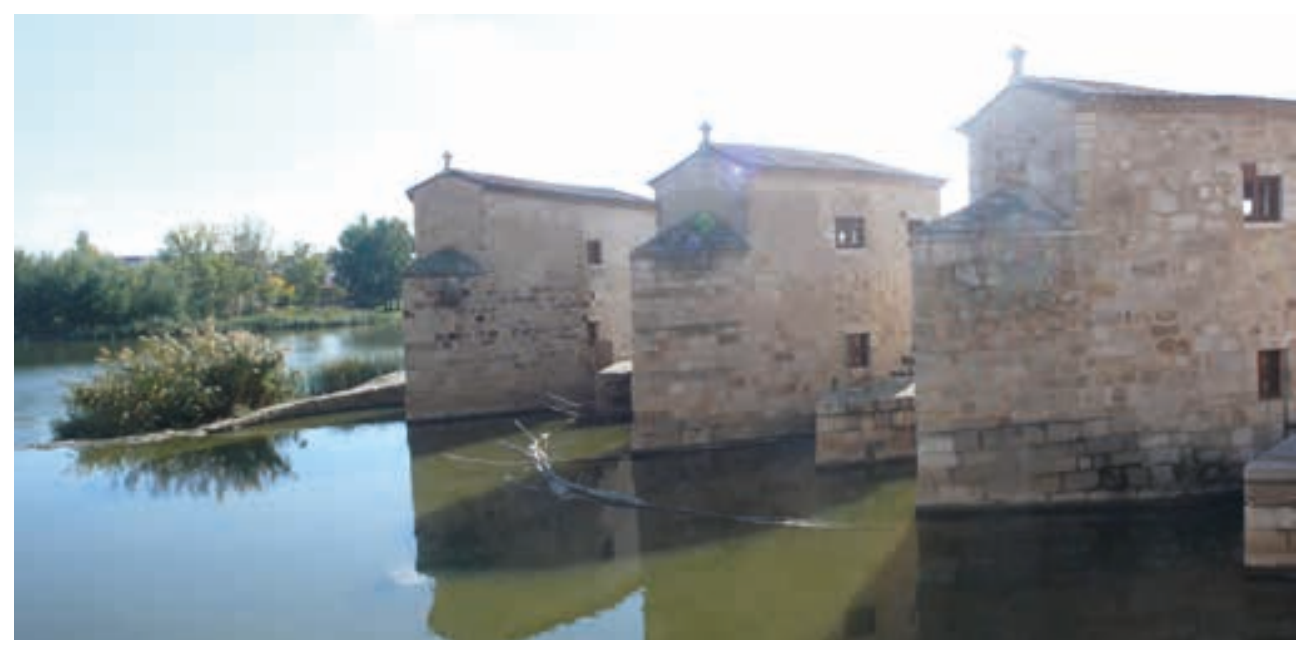

3. Aceñas, en Zamora. Foto C. N.

4 Los estudios de Leonardo da Vinci sobre el agua se encuentran en los Códices de la Biblioteca Nacional de Madrid, en cinco volúmenes. Sus estudios sobre el agua han sido reunidos recientemente por Juan Barja en Libro del agua (Akal, 2017). Los libros de Juanelo Turriano se encuentran en la Biblioteca Nacional de Madrid y fueron reeditados en el Colegio de Ingenieros de Caminos, Canales y Puertos en 1983, atribuyéndoselos a Pseudo Juanelo Turriano por las dudas existentes sobre la autoría. El libro de Julio Caro Baroja Tecnología popular española fue publicado por Editora Nacional (Madrid) en 1983. Para un estudio amplio de Fábricas hidráulicas españolas, véase: González Tascón, Ignacio (1987), MOPU, CEHOPU; Ruíz Bedía, María Luisa (dir.) (2009): Infraestructuras y aprovechamientos hidráulicos en Cantabria, CEHOPU, y Fundación Caja Murcia (2005): La cultura del agua en la cuenca del Segura, Murcia. 
Lo que nos interesa destacar es la forma en que estas fábricas hidráulicas han jalonado el curso de los ríos, tanto principales como secundarios, y el hecho de que hoy podamos relacionarnos con ellas a través de las ruinas, en la mayor parte de los casos, o de las rehabilitaciones que también se han llevado a cabo de molinos, bateas y ferrerías, como parte de proyectos de recuperación de itinerarios en las márgenes de los ríos secundarios o de parques e itinerarios en los ríos principales para la recuperación de las relaciones de las ciudades en sus ríos, que comentaremos en un apartado posterior. Cuando miramos desde los puentes o desde los paseos las márgenes de los ríos principales, como en el caso del Duero en Tordesillas o Zamora, nos encontramos con las aceñas harineras, cuya construcción implicaba también la construcción de una presa y un canal en el río para garantizar el caudal del agua. Lo mismo ocurre en Salamanca o Valladolid: los molinos harineros, de menor dimensión que las aceñas, se extendían por todos los ríos secundarios de la península. El aprovechamiento de las aguas a través de la sucesión de molinos lo encontramos en numerosos arroyos en pendiente ${ }^{5}$.

Los riegos de Levante, extendidos a la España mediterránea, están relacionados con las norias para elevar las aguas, como la de Alcantarilla o La Nora (en la provincia de Murcia), para el riego. La elevación del agua de los ríos a las ciudades para el abastecimiento, como en los dibujos de Leonardo da Vinci, con la rueda hidráulica acoplada en los tornillos de Arquímedes o el artificio que diseñó Turriano en el siglo XVI para elevar el agua a Toledo, supuso uno de los grandes fracasos de esta tecnología hasta que en el siglo XIX se resolvió el problema con la máquina de vapor. Antes de la generalización de esta máquina, la tecnología tradicional fue sirviendo a las fábricas que aprovechaban la energía hidráulica, como en las fábricas harineras en el siglo XVIII, que cada vez tenían mayores dimensiones, como los Molinos del Segura en Murcia, o en torno a las esclusas de los canales de navegación, y en las siderurgias como las de La Cavada y Liérganes (Cantabria), o la de Sargadelos, en Cervo (Galicia), que supusieron un salto de escala respecto a las ferrerías anteriores y que también podemos asociar al paisaje cultural de los ríos, aunque en este caso se trataba de ríos secundarios que

5 Véase el capítulo VII de la obra citada de González Tascón, Ignacio (1987). Véase también Llanos Martínez, M. / M. a Martínez Martina (1993): Orígenes y experiencias de los molinos hidráulicos en la ciudad y huerta de Murcia, Ayuntamiento de Murcia. 
desembocaban en los principales o en el mar. Asociados a los ríos están también los ingenios para fabricar papel, con molinos papeleros situados en los ríos ya desde el Medievo, como por ejemplo el caso del Guadalquivir, que nos muestra los grabados del siglo XIX de David Roberts y cuya técnica se extenderá hasta el siglo XIX, o al servicio de la industria algodonera, como en Béjar.

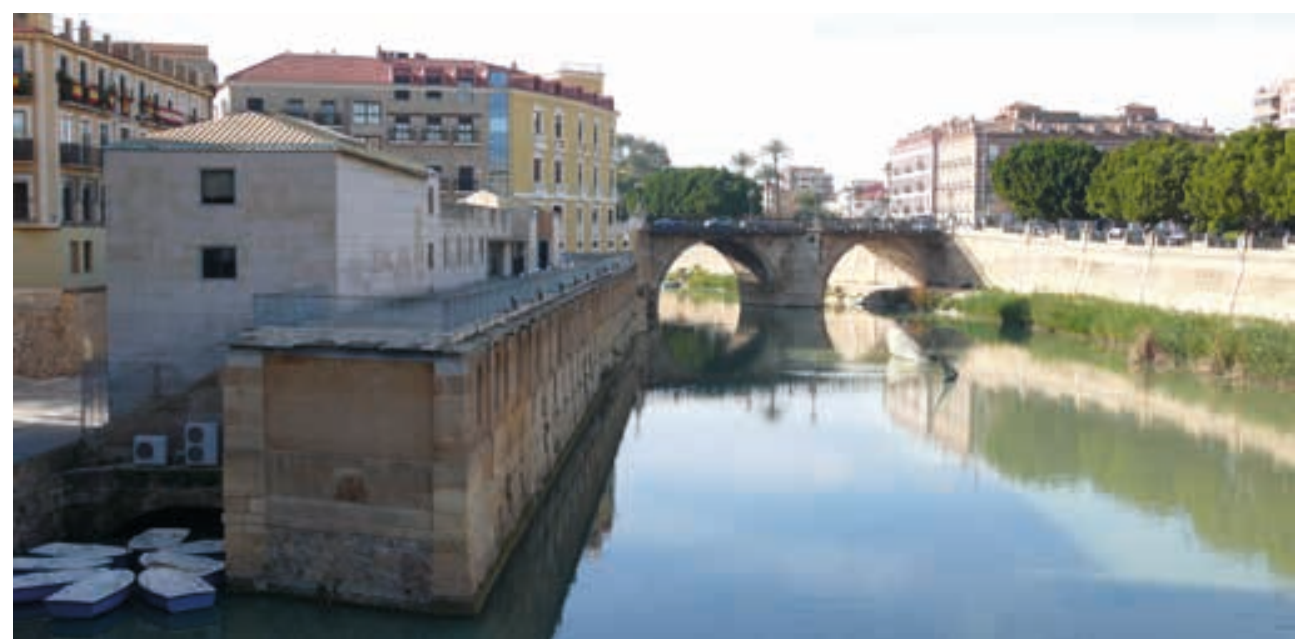

4. Los Molinos del Segura, en Murcia. Foto C. N.

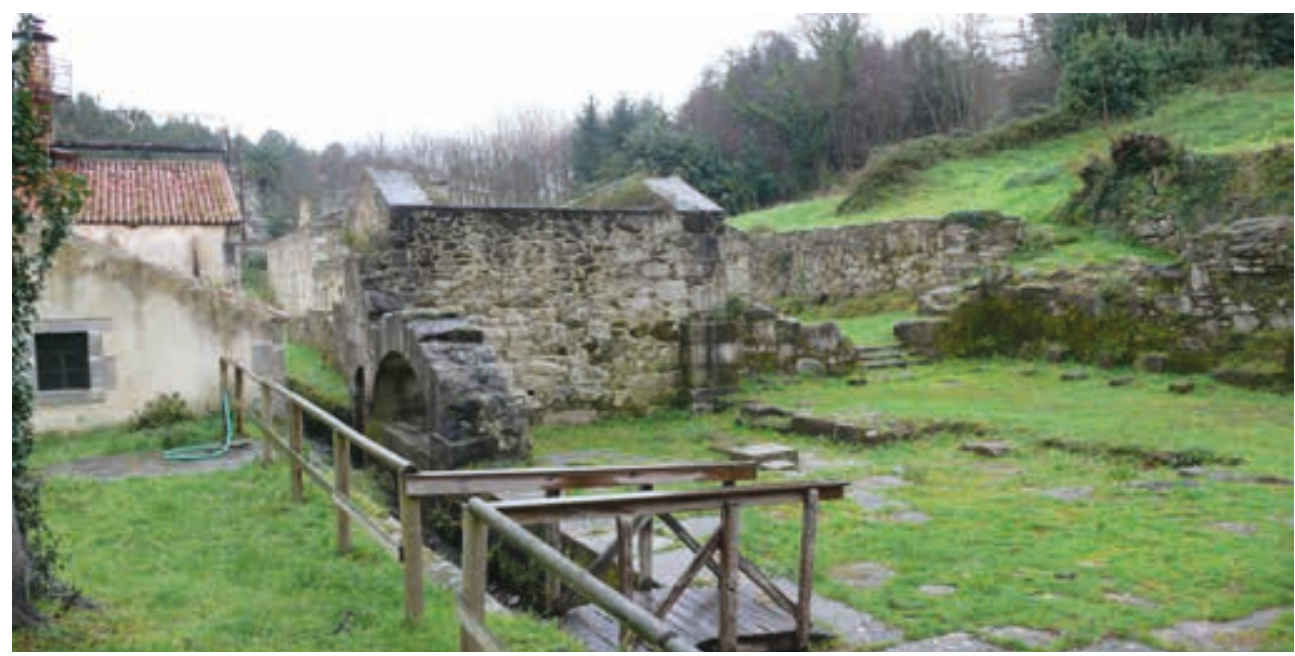

5. Sargadelos, en Cervo (Galicia). Foto C. N. 
Uno de los elementos fundamentales del paisaje cultural de los ríos son los puentes históricos que están en el origen de las ciudades, como muchos de los puentes de piedra que todavía se conservan o aquellos que daban continuidad a caminos históricos sobre los ríos. El valor patrimonial y paisajístico de estos puentes se ratificó a partir de la década de 1970, con inventarios y catálogos en los que el puente histórico, relacionado con un paisaje urbano o no, aparece convertido en referencia del lugar, el cual no sería reconocido sin su presencia. Se trata de puentes en ruinas y puentes restaurados que no solamente permiten el cruce de los ríos de una manera distinta a los puentes actuales, sino que, a través de su acceso por caminos y carreteras, nos permiten relacionarnos con paisajes en los que el elemento de referencia es el propio puente; puentes de piedra, de madera y metálicos (previos a los primeros puentes de hormigón del siglo xx) que marcan el paisaje de los ríos. Al recorrer sus márgenes, nos relacionamos con sus elementos constructivos, sus pilas, sus tableros y sus estribos, con tipologías relacionadas con las vigas y los arcos. Los puentes de menores dimensiones de los ríos pequeños que intentan saltar el río de una vez mediante arcos se traducen en sucesiones de arcadas y de vigas en los ríos mayores. Cabe prestar especial atención a los puentes pequeños, construidos con pequeñas losas de piedra (como as pontellas, en Galicia), con vanos adintelados, que daban continuidad a caminos históricos y rurales antes de que fuesen sustituidos por puentes modernos. Su asociación a caminos históricos y al acceso a las fábricas hidráulicas, como los molinos, hacen que formen parte también del patrimonio cultural asociado a los ríos, cuya integración, además, se produce por ser rebasados por las aguas ${ }^{6}$.

6 Un primer inventario de puentes se acometió bajo la dirección de José A. Fernández Ordóñez en la Cátedra de Historia y Estética de la Escuela de Ingenieros de Caminos, Canales y Puertos, en Madrid, entre 1978 y 1980, con el título «Inventario de puentes españoles de interés histórico artístico anteriores a 1936», y que recibió entonces la crítica de aquellos que consideraban los puentes solo como obras útiles, con la excepción de algunos puentes romanos o medievales. Extendidos a toda una comunidad autónoma, pueden considerarse como primeros catálogos el publicado por Fernández Ordóñez, José (dir.) / Tomás Abad / Pilar Chías (1988): Catálogo de puentes anteriores a 1936, León, Madrid, Biblioteca CEMOPU (a partir de la información del inventario anterior), y el que publicamos en 1989: Alvarado, Segundo / Manuel Durán / Carlos Nárdiz: Puentes históricos de Galicia, [A Coruña / Santiago de Compostela], Colegio Oficial de Ingenieros de Caminos, Canales y Puertos / Dirección Xeral do Patrimonio Histórico e Documental. 


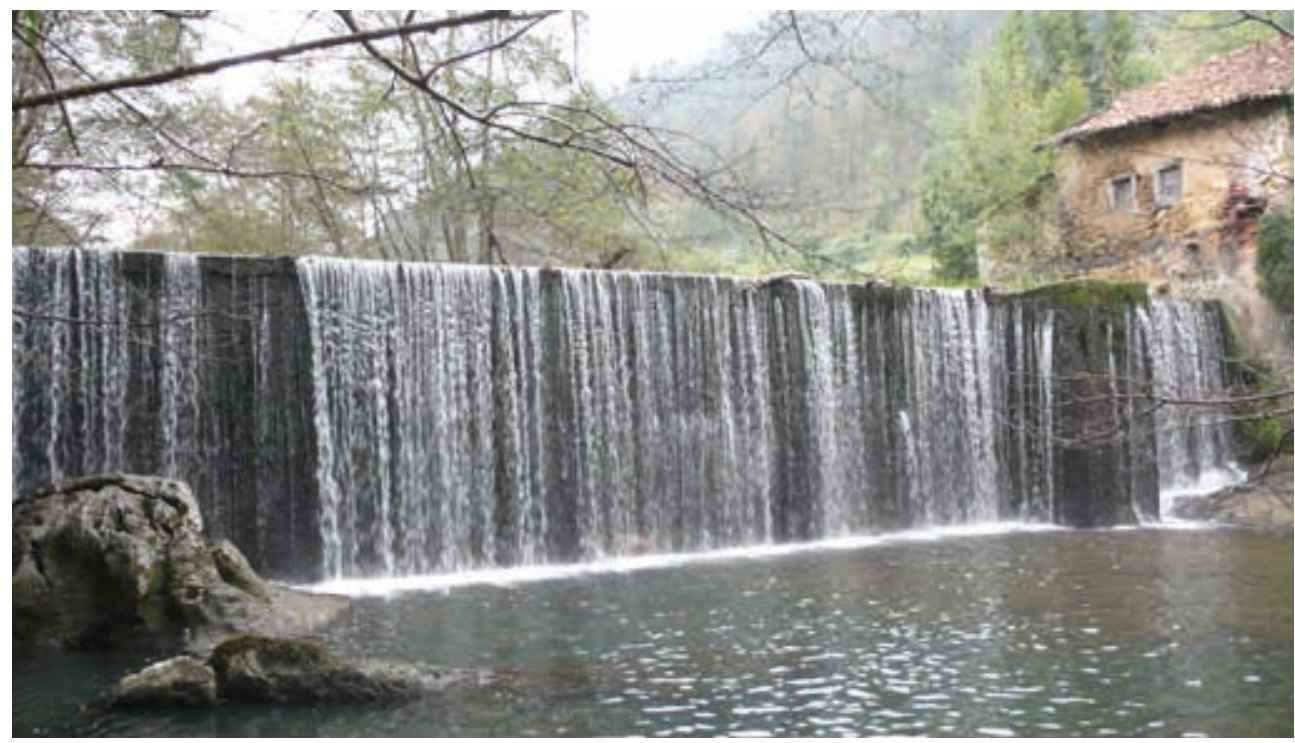

6. Presa, en el Tea. Foto C. N.

La construcción de embalses, a partir de la década de 1930, para la explotación integral de los ríos determinó que algunos de estos puentes quedaran bajo las aguas del embalse y aparezcan hoy solo visitables en aguas bajas. En otros casos, como los de Alcántara o Alconétar, el valor del puente romano determinó la construcción de la presa aguas arriba, en el caso de Alcántara, o el traslado del propio puente de Alconétar, que, al quedar fuera de los caminos o vías que le daban acceso, necesita proyectos de ordenación del entorno que vayan más allá de la protección del puente ${ }^{7}$.

A diferencia de los puentes, la presencia de muelles y rampas para el cruce en barca de los ríos es más difícil de identificar, por haber sido sustituidos por puentes. Las rampas se utilizaron como alternativa a los puentes en puertos fluviales en aquellos momentos en los que el puente estaba en ruinas en las ciudades. Resultan más fáciles de identificar en el caso de las rías o en la desembocadura de los ríos, lugares en los que los puentes se han construido más tardíamente en sustitución del paso de barcas (hasta al menos mediados del siglo xx) o en los que

\footnotetext{
Véase, por ejemplo, Plasencia Lozano, Pedro (2012): «Alconétar, paisaje cultural de la ingeniería. Una propuesta de ordenación territorial», en M. ${ }^{a}$ del Mar Lozano Bartolozzi / Vicente Méndez Hernán (coords.), Paisaje modelados para el agua: entre el arte y la ingeniería, Cáceres, Editora Regional de Extremadura, 187-205.
} 
todavía se utilizan hoy en día para facilitar el acceso de las embarcaciones de pesca o deportivas. Sin embargo, la memoria de estos pasos todavía está presente, como en los numerosos puertos fluviales que hubo por ejemplo en el Miño, al igual que también ocurre con los muelles y rampas en sus desembocaduras.

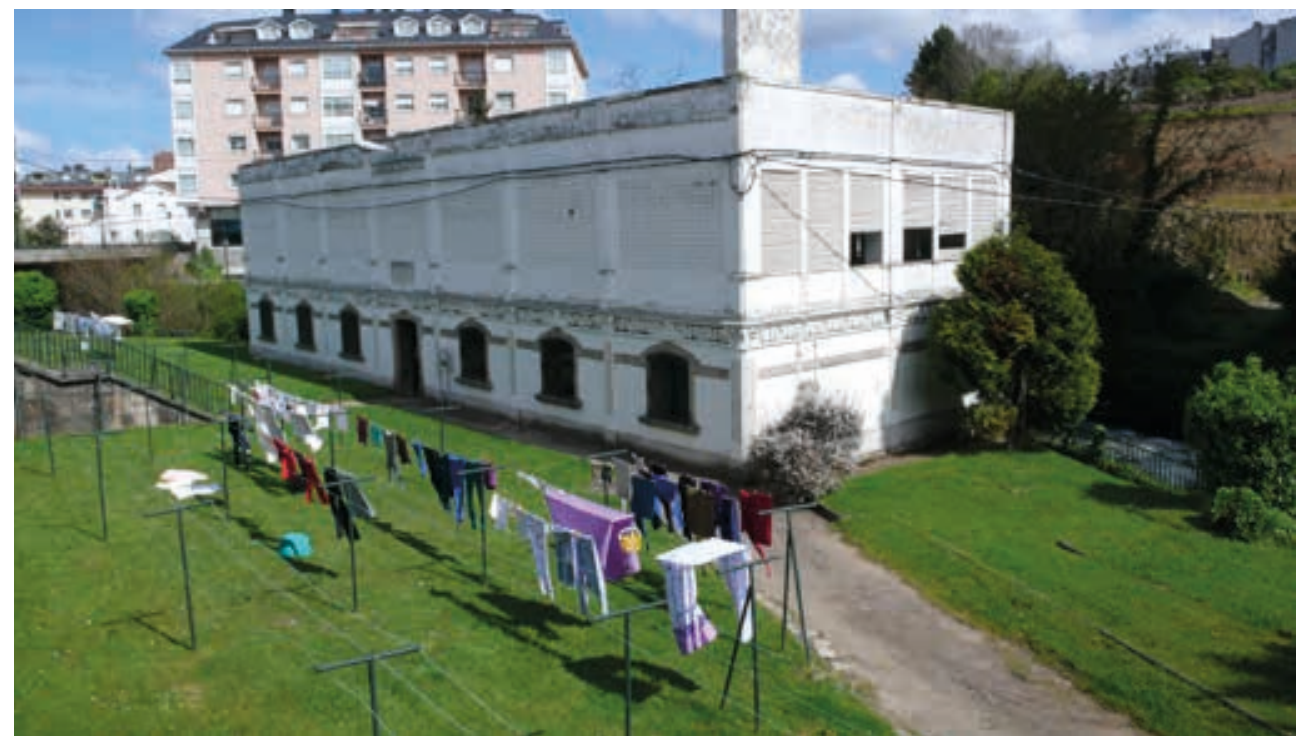

7. Lavadero, en Betanzos. Foto C. N.

Los ríos conservan, además, la huella de la presencia de lavaderos construidos con losas de piedra, como en Ponte Maceira en el Tambre, o a través de edificios específicos, como en Betanzos. Todos los ríos y sus márgenes (incluido el propio Manzanares, en Madrid) fueron objeto de este tipo de actividades, al igual que estuvieron en algún momento destinados al baño; unos usos que fueron desapareciendo a partir de los años sesenta debido al establecimiento de las industrias en sus márgenes y a la contaminación extrema de sus aguas.

La rehabilitación de centros históricos, como en el caso de Allariz, ha afectado a la rehabilitación de las fábricas (por ejemplo, de curtidos) de sus márgenes. Las industrias también buscaron en las márgenes de los ríos (como en Cataluña, por ejemplo, en el Llobregat) soporte para sus actividades, estableciendo en las márgenes fábricas y poblados que hoy forman parte del paisaje cultural del río, a pesar de su carácter obsoleto. 


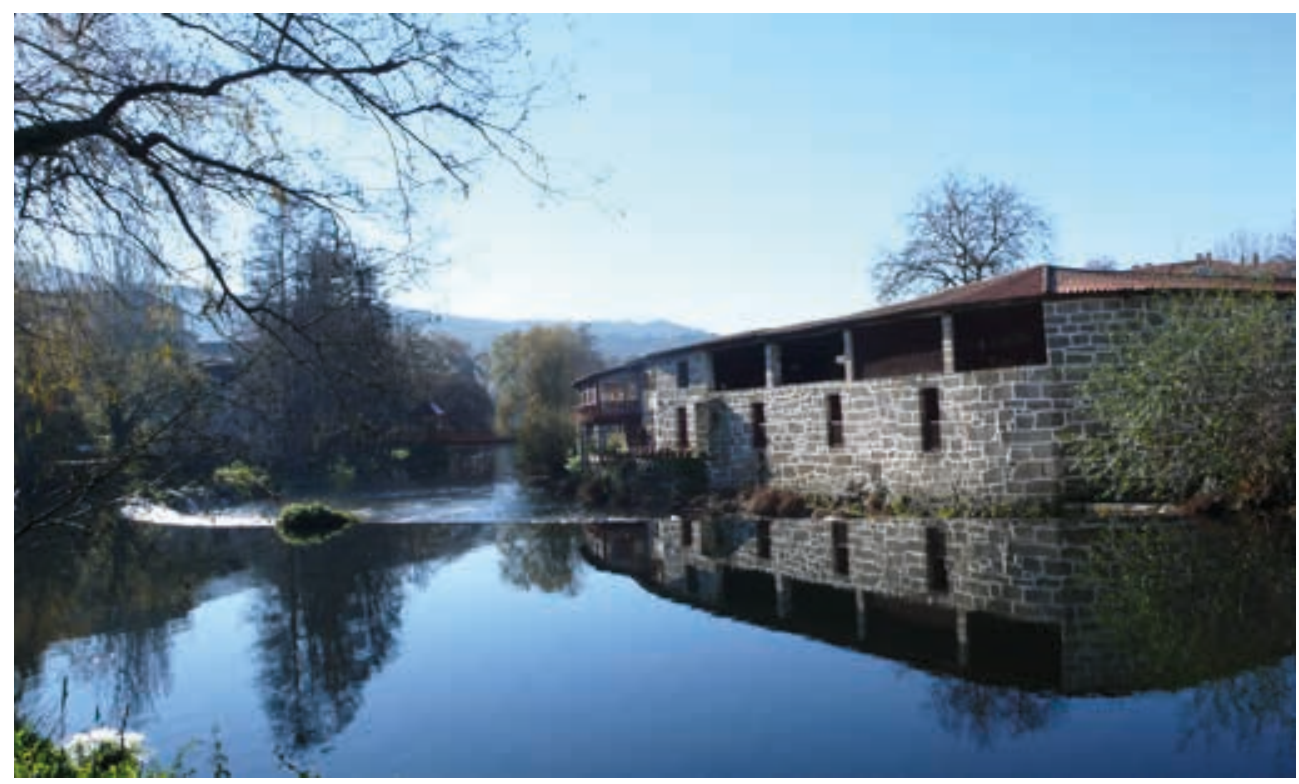

8. Fábrica de curtidos, en Allariz. Foto C. N.

El corredor del Llobregat (con más de $170 \mathrm{~km}$ desde los Prepirineos hasta las llanuras y un tramo intermedio en las tierras de El Bages hasta Manresa, en donde recibe al Cardener) aparece cruzado por una serie de puentes históricos y en sus márgenes se asentaron colonias textiles (fábricas y poblados) derivadas de la industrialización (especialmente entre Navas y Gironella), como Cal Vidal y Viladomiu. El río se vuelve a abrir en Martorell, donde pierde su valor ecológico debido a las industrias y vías de comunicación que ocupan todas sus márgenes excepto en aquellas bañadas por las llanuras de inundación, en donde se realizó una propuesta de creación de un parque agrario hasta la desembocadura en el delta (tramo en el que se desvía el río para la ampliación del aeropuerto del Prat $)^{8}$.

8 Las propuestas para la recuperación de este río y del patrimonio cultural asociado fueron objeto de distintas publicaciones, promocionadas por la Universidad Politécnica de Cataluña (a través del Departamento de Urbanismo y Ordenación del Territorio), con trabajos coordinados y dirigidos por Joaquín Sabaté, como Patrimonio y proyecto territorial. Colonias, Sèquia de Manresa y Delta del Llobregat, Diputación de Barcelona, 2004, o Dinamizando los ejes fluviales del Bages: el Baix Cardener y el Llobregat, Universitat Politècnica de Catalunya, 2015. 


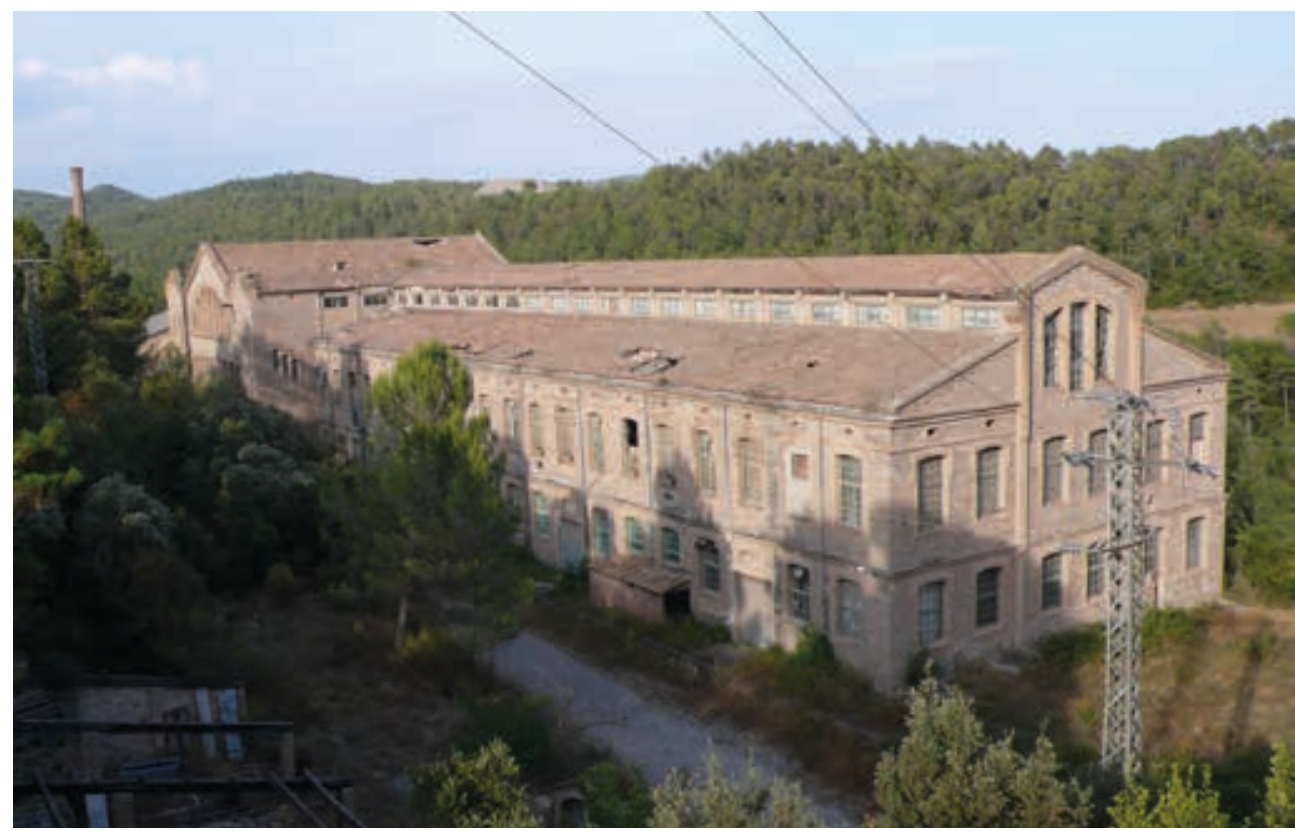

9. Fábrica de Cal Vidal, en el Llobregat. Foto C. N.

Los ríos (y sus valles asociados) que no han sido afectados por la industrialización pueden buscar alternativas en el fomento del turismo asociado al recorrido del patrimonio industrial y cultural, con miradores e itinerarios, como por ejemplo en el valle del Nansa (en Cantabria) o en la Ribeira Sacra (en Galicia), que nos ponen en contacto con las potencialidades de los valles recorridos por los ríos, que han soportado formas ancestrales agrícolas de explotación de sus laderas y llanuras inundables. Podemos disfrutar de experiencias de este tipo en lugares como, por ejemplo, el Alto Douro Vinhateiro (en Portugal), convertido en Patrimonio mundial de la UNESCO en diciembre del 2001 (por las formas de explotación y construcción de los vinos de la región) y que ofrece recorridos turísticos en las zonas navegables del Duero (solo posible por la construcción de presas) entre Oporto y Pocinho?.

9 Véase, por ejemplo, Nárdiz Ortiz, Carlos (2016): «La Ribera Sacra. Entre el arte, la naturaleza y la ingeniería», Revista de Obras Públicas, 3576, 29-40, y Nárdiz Ortiz, Carlos (2017): «Patrimonio cultural. Corredores fluviales e infraestructuras verdes», Revista de Obras Públicas, 3591, 72-83. 


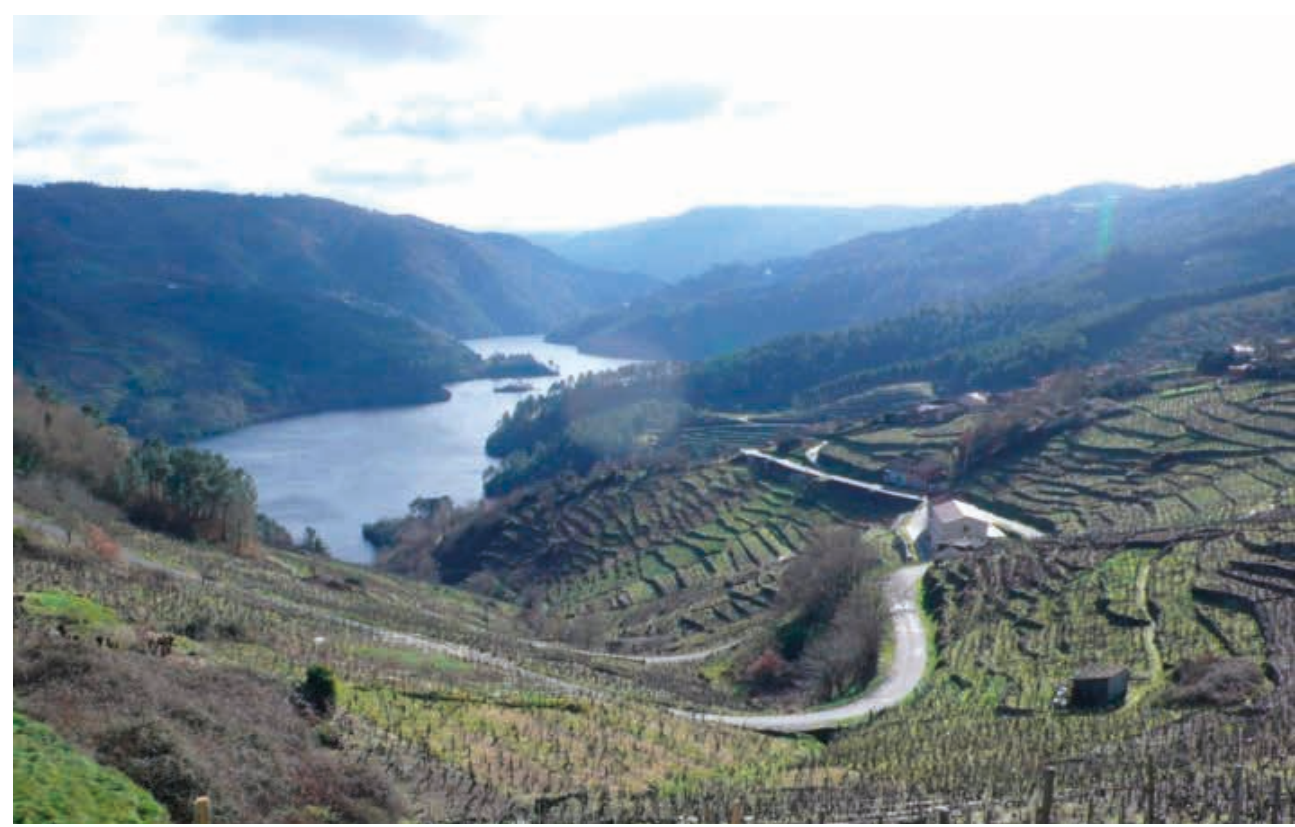

10. Socalcos, en la Ribeira Sacra, en el Miño. Foto C. N.

En los tramos en los que los ríos atraviesan tierras llanas donde sus aguas se convierten en el principal recurso de la agricultura, el paisaje del río es también el de los pueblos del entorno, crecidos alrededor de las explotaciones agrícolas del suelo potenciadas por el riego, en algunos casos con nuevos poblados de colonización. Este fue el caso de los poblados crecidos en torno al valle del Tiétar o en las Vegas Altas y Bajas del Guadiana (en Extremadura), a partir de la década de 1940, cuyas maneras de edificación, de ordenación y de equipamientos pueden considerarse que hoy forman parte del patrimonio cultural ligado a los valles de los ríos ${ }^{10}$.

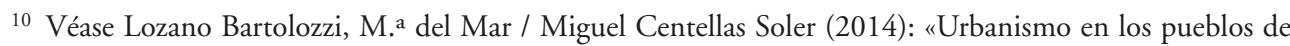
colonización del valle del Tiétar», en M. ${ }^{a}$ del Mar Lozano Bartolozzi / Vicente Méndez Hernán (coords. y eds.) (2014), Patrimonio cultural vinculado con el agua. Paisaje, urbanismo, arte, ingeniería y turismo, Cáceres, Editora Regional de Extremadura, 143-170. Véase también Abujeta Martín, Esther (2017): «Análisis y diagnóstico. Paisaje, urbanismo y patrimonio en los pueblos de colonización de las Vegas Altas del Guadarrama (Badajoz)», en M. ${ }^{a}$ del Mar Lozano Bartolozzi / Vicente Méndez Hernán (coords. y eds.), Paisajes culturales del agua, Cáceres, Editora Regional de Extremadura, 191-206. 
Asociados a estos poblados están las infraestructuras hidráulicas (canales, acequias, acueductos), las redes de caminos e incluso las intervenciones en repoblaciones forestales, aparte de las viviendas, calles y equipamientos de los propios núcleos y las grandes extensiones a su alrededor de superficies de regadío que, al igual que otros territorios transformados históricamente, constituyen hoy paisajes culturales dignos de ser protegidos. Y ello en general afecta a los terrenos agrícolas formados en los valles de los ríos, principales y secundarios ${ }^{11}$.

11 Véase Nárdiz, Carlos (2017): «Patrimonio Cultural. Corredores fluviales e infraestructuras verdes», Revista de Obras Públicas, 3591, 72-83. 
EL PAISAJE Y EL PATRIMONIO CULTURAL DE LAS RIBERAS DEL TAJO EN EXTREMADURA

María del Mar Lozano Bartolozzi

Universidad de Extremadura

DOI: 10.17075/pvpcr.2021.002 



\section{INTRODUCCIÓN}

Las cuencas de los ríos son espacio y fuente de recursos que han dado lugar a un gran número de elementos patrimoniales testigos de nuestra civilización e identidad. Como consecuencia, han configurado determinados paisajes culturales ${ }^{1}$.

En este escenario, una parte de las investigaciones que desarrolla el grupo de investigación que yo coordino en la Universidad de Extremadura ${ }^{2}$ versa sobre el paisaje y el patrimonio de las riberas de los ríos Tajo y Guadiana. Para ello, ha sido importante haber obtenido tres proyectos de investigación en convocatorias competitivas nacionales ${ }^{3}$ que tienen como espacio de laboratorio los citados ríos y sus cuencas fluviales en la región extremeña. Así mismo, hemos mantenido el compromiso de transferencia de resultados con la celebración de seminarios científicos internacionales, cursos y ciclos de conferencias a los que hemos invitado a investigadores que tienen relación conceptual o metodológica con nosotros para intercambiar experiencias. Hemos publicado artículos y libros, algunos colectivos, y hemos presentado ponencias, en congresos nacionales e internacionales, de historia del arte, ingeniería, arquitectura, desarrollo rural y tutela del patrimonio. Se añade la relación con otros grupos de investigación y sus proyectos ${ }^{4}$.

1 Quiero agradecer al doctor Carlos Nárdiz y al Consello da Cultura Galega la invitación a participar en estas jornadas sobre la puesta en valor del patrimonio cultural de los ríos en Galicia.

2 Las personas que hemos colaborado en los proyectos nacionales somos: Esther Abujeta Martín, Marina Bargón García, Moisés Bazán de Huerta, Javier Cano Ramos, Miguel Centellas Soler, Josefa Cortés, María del Carmen Diez González, Alberto Flores Galán, Nuria María Franco Polo, María del Mar Lozano Bartolozzi, José Maldonado Escribano, Vicente Méndez Hernán y Pedro Plasencia-Lozano.

3 El primero se denomina «Entre Toledo y Portugal: miradas y reflexiones contemporáneas en torno a un paisaje modelado por el Tajo» (HAR2010-21835); el segundo, «La patrimonialización de un territorio: conformación de paisajes culturales entre el Tajo y el Guadiana en Extremadura» (HAR2013-41961-P), y actualmente está en curso el tercero, bajo el título: «Paisajes culturales en la Extremadura meridional: una visión desde el patrimonio» (HAR2017-87225-P). Nuestros comentarios derivan de las aportaciones y reflexiones de estos proyectos.

4 Como el de la Universidad de Santiago de Compostela: «Arte y monasterios. La aplicación del patrimonio artístico a la sostenibilidad de la Ribeira Sacra (Montederramo y Ribas De Sil)»; el de la Universidad de Oviedo: «Espacios portuarios y villas costeras: modelos de estrategias urbanísticas y patrimoniales de regeneración y transformación del litoral asturiano», o el de la Universidad de Granada: «El Patrimonio agrario. La construcción cultural del territorio a través de la actividad agraria», centrado en la Vega del Genil. Así mismo, colaboramos con la doctora Maria Martone, arquitecta de la Università della Sapienza di Roma, y con profesoras de la Universidad de Coimbra y de la Universidad de Oporto, expertas en temas del patrimonio histórico-artístico de sus territorios. 
Estudiamos este patrimonio tanto a escala territorial como en aproximaciones interdisciplinares a distintos aspectos ${ }^{5}$. Además, el concepto de paisajes culturales es la base de estos proyectos y ha dado paso a la publicación en cuatro volúmenes de un catálogo de paisajes culturales de Extremadura que sigue las directrices del Plan Nacional de Paisajes Culturales ${ }^{6}$, reflejado en la publicación 100 paisajes culturales en España. En esta publicación (Cruz, 2015) se han clasificado los paisajes como: paisajes agrícolas, ganaderos y forestales; paisajes industriales, infraestructuras y actividades comerciales; paisajes urbanos, históricos y defensivos, y, por último, paisajes simbólicos.

Nosotros hemos seguido otros hilos conductores con respecto a la clasificación de paisajes, como vamos a exponer en este artículo; pero, antes, debemos situarnos en nuestro contexto del río Tajo, en su curso medio bajo.

\section{EL PATRIMONIO DEL RÍO TAJO A SU PASO POR EXTREMADURA}

El río Tajo a su paso por Extremadura ha proporcionado recursos a los primeros pobladores y a todas las etapas históricas que han desarrollado determinadas ocupaciones en un paisaje de carácter mediterráneo donde el agua ha sido razón de la fundación de pueblos y ciudades, así como de las dotaciones en un territorio organizado con distintos trazados de caminos. No vamos a ahondar en el importante patrimonio natural con su fauna y flora, sino en el patrimonio histórico-artístico de este corredor fluvial, a sabiendas de que no debemos perder de vista la relación entre arte y naturaleza para entender correctamente este paisaje cultural, es decir, este paisaje humanizado.

5 Unas aproximaciones que intentamos que sean interdisciplinares en la medida de nuestras posibilidades, al ser un equipo integrado en su mayoría por historiadores del arte y gestores culturales, además de por un ingeniero de caminos y un arquitecto.

6 Coordinados por Javier Cano, director del Centro de Conservación y Restauración de Bienes Culturales de la Junta de Extremadura, y Nuria Franco, técnica de Arte de dicho centro. Javier Cano es también miembro de la Comisión de Seguimiento del Plan Nacional de Paisaje Cultural y fue representante científico, tanto de la Junta de Extremadura como del Gobierno de España, en el programa Interreg Europe, del Proyecto SHARE, entre 2017 y 2020, con el que se pretende promover el desarrollo sostenible del patrimonio cultural en áreas urbanas y rurales recalificadas de Europa. 
Los testimonios de interacción con el territorio nos llevan a la Prehistoria, concretamente al Paleolítico y a la Edad de Bronce. Este es el resultado lógico de todos los procesos de organización y ordenación del territorio que se han desarrollado secularmente y nos han dejado pinturas y grabados rupestres, además del potente megalitismo que se manifiesta en los abundantes dólmenes, como los 43 catalogados en Valencia de Alcántara y en otras zonas ribereñas del Tajo. La etapa romana consolidó la llamada Vía de la Plata o Iter ab Emerita Caesaraugustam, y otros caminos transversales que ordenaron y transformaron el territorio del oeste peninsular, aprovechando rutas anteriores de tartessos y vetones. El proyecto Alba Plata sirvió para la recuperación y revalorización de esta ruta por medio de fondos europeos y autonómicos que posibilitaron la construcción de puentes excepcionales, como el de Alcántara y el de Alconétar, además de la recuperación de restos de calzadas, mansiones y poblaciones, como Cáparra (figura 1) o Augustóbriga, hoy inundada por las aguas del embalse de Valdecañas (aunque sí se salvaron los restos de su templo romano).

Relevante fue la presencia islámica, que formó enclaves fronterizos en la orilla izquierda del Tajo, con poblaciones en las que destacan sus alcazabas y castillos, así como la actividad y fundaciones de las órdenes militares, dada su contribución a la reconquista, la repoblación y la construcción de interesantes edificios. Se añaden las ciudades, reconquistadas o fundadas ex novo, de señorío o de realengo, para igualmente reforzar la defensa y repoblación, tras la recuperación del territorio, con sus distintas funciones, siempre ligadas en gran parte al agua. Se suman el establecimiento de órdenes religiosas, inmersas en el paisaje, y la creación del Honrado Concejo de la Mesta en el siglo XIII, vigente hasta el siglo XIX, que organizó rutas de trashumancia

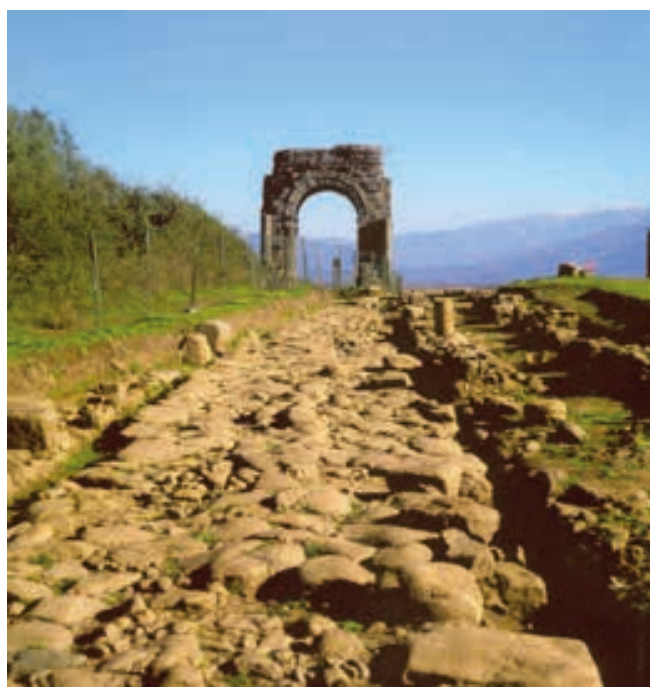

Figura 1. Yacimiento arqueológico de Cáparra por las vías pecuarias del territorio. 
El Tajo fue también testigo de la cultura humanista, como en el jardín de los duques de Alba, en el palacio de Abadía, junto al río Ambroz, donde se desarrolló la academia literaria El arca de Albano, glosada por Garcilaso de la Vega y Lope de Vega, entre otros escritores. Se trata de un jardín casi desaparecido, pendiente de una prospección arqueológica, la restauración de algunos elementos que existen y una conservación sostenible.

Avanzando en el tiempo se refuerzan las defensas en las poblaciones de frontera ante los conflictos bélicos de Portugal y de los franceses. Durante la Ilustración, se mejoran las obras públicas y los caminos, y se funda alguna población, como Villareal de San Carlos, para reforzar la vigilancia de los caminos ante el bandolerismo (figura 2).

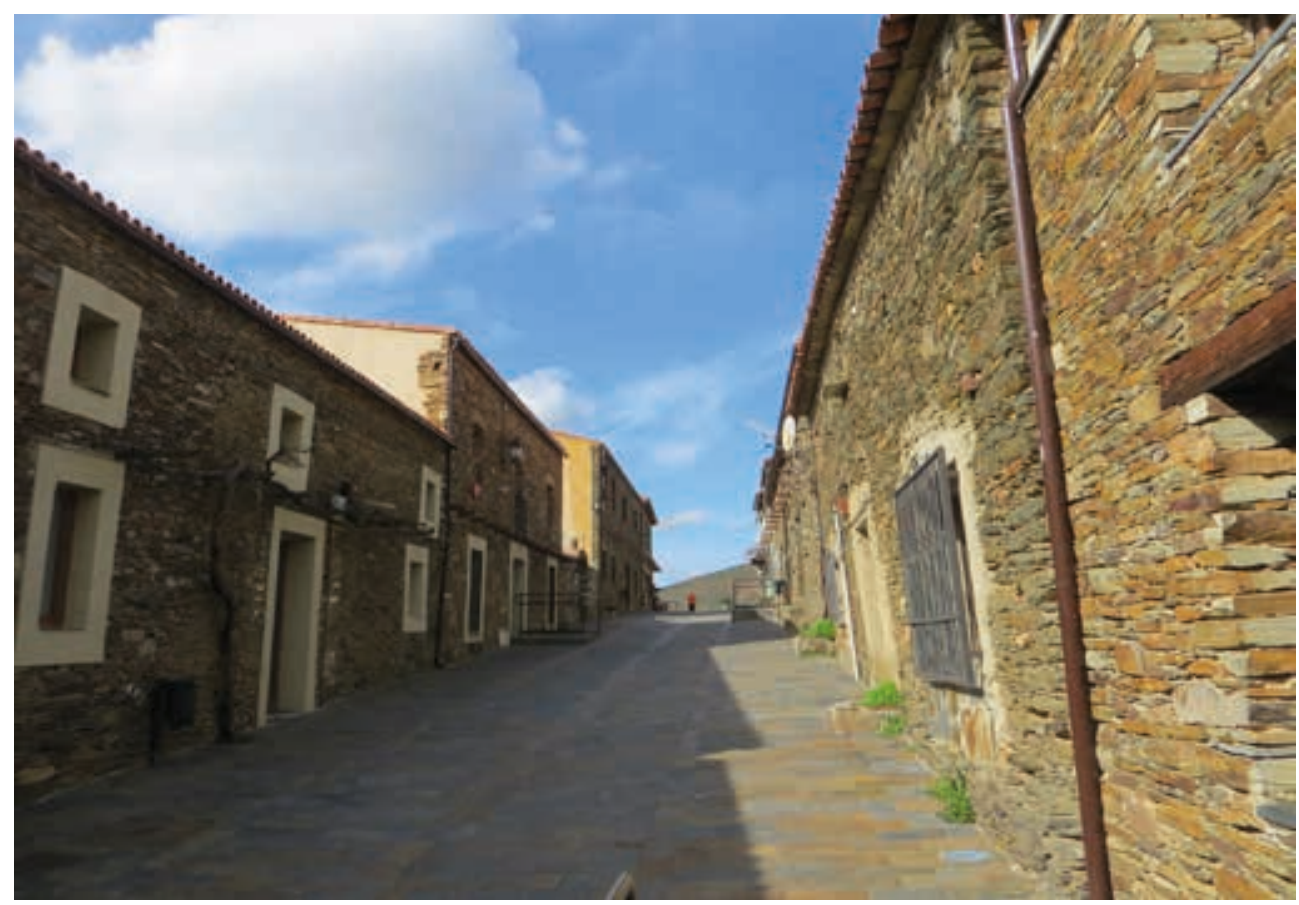

Figura 2. Villarreal de San Carlos, fundación de Carlos III, 1781

La Revolución industrial, con sus fábricas y minas, y la llegada del ferrocarril crearon sus corredores norte-sur, este-oeste, y dejaron huellas interesantes, algunas de las cuales se han perdido o están pendientes de rehabilitación. 
Durante el franquismo, se hicieron grandes obras hidráulicas y pueblos de colonización para frenar la emigración y mejorar la explotación del campo, caracterizando nuevos paisajes. Por su parte, la etapa contemporánea ha dado lugar a intervenciones en la naturaleza de obras públicas, como las del ferrocarril de alta velocidad, ahora en curso, y también a la creación de parques nacionales y reservas de la biosfera, como distintas ZEPAS (zonas de protección de aves). Igualmente, se han construido elementos para el ocio en los embalses, con arquitecturas que miran al agua, o para la creatividad y el diálogo entre el arte y la naturaleza, como el internacional Museo Vostell Malpartida. Además, se han transformado algunos edificios históricos para uso turístico, tales como las hospederías en antiguos conventos y otras edificaciones (Abujeta, 2016).

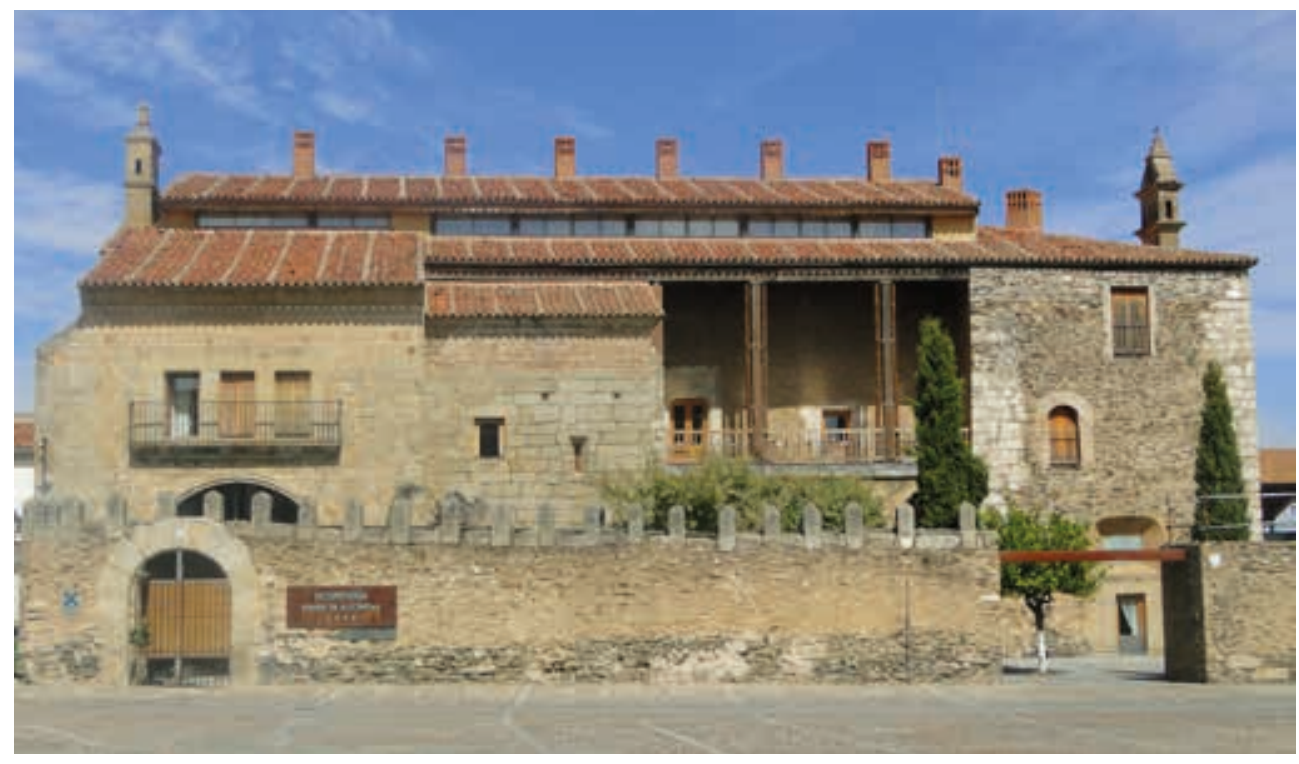

Figura 3. Hospedería Puente de Alconétar, en la plaza Mayor de Garrovillas (antiguo palacio de los Alba de Aliste, siglo Xv. Arquitectos encargados de la rehabilitación: Jorge López y Santiago Martínez Corrales, 1997)

A todo ello se suma el patrimonio subacuático de todas las cronologías tras la construcción de embalses. En resumen, estamos hablando de un patrimonio que va desde la Prehistoria hasta el mundo contemporáneo: desde las estructuras megalíticas, a puentes y viaductos, además de poblados, estructuras industriales y ferroviarias. 


\section{ANÁLISIS METODOLÓGICO Y CRÍTICO DEL PATRIMONIO}

En 1992, la Convención del Patrimonio de la Humanidad reconoció que los paisajes culturales representan «obras combinadas de la naturaleza y el ser humano", por lo que, de acuerdo con el Convenio Europeo del Paisaje celebrado en Florencia en el año 2000, planteamos acometer la identificación y la cualificación de determinados paisajes culturales con la selección de algunos de sus bienes patrimoniales mediante el análisis de sus características y la consideración de sus valores históricos y artísticos particulares. No obstante, no abordamos los paisajes como en el mencionado programa del Ministerio, sino con otros parámetros adaptados a nuestras propias inquietudes y miradas, como si se tratara de unidades culturales que lógicamente también pudieran superponerse.

Entendemos como paisaje cultural la percepción de la acción antrópica del ser humano en la naturaleza y en un espacio territorial y temporal concreto, lo que ha dado lugar a un patrimonio histórico-artístico y cultural con señas de identidad. Por tanto, un patrimonio de sitios históricos, bienes muebles e inmuebles, materiales e inmateriales, tangibles e intangibles, no entendidos de forma aislada, sino con interacciones territoriales, medioambientales, urbanísticas, sociológicas, etc. Un patrimonio del que también forman parte su representación en la cartografía, las obras de arte, la fotografía, el cine y las artes de acción como las performances, la música y la literatura. Un patrimonio que intentamos catalogar e inventariar en su propio territorio, con una metodología interdisciplinar y transversal para colaborar en las medidas de gestión, conservación y tutela gracias a la aportación de conocimiento y con recursos que sirvan para fomentar las políticas de explotación agraria sostenible, el turismo cultural, la restauración y rehabilitación de algunos de estos bienes o de los pueblos adaptando la imagen del pasado a las necesidades y nuevas oportunidades del presente; ofreciendo una visión del paisaje desde un punto de vista dinámico.

Lo hacemos en un arco temporal, entre la Edad Moderna y el siglo XXI inclusive, con leves alusiones a épocas anteriores, pues, por ejemplo, la arqueología, la Prehistoria y la historia antigua están siendo estudiadas de manera específica por investigadores de la Universidad de Extremadura y del Instituto de Arqueología de Mérida.

Así mismo, hemos establecido unas líneas de trabajo concretadas en el estudio de determinados objetivos que hemos identificado bajo el denominador común de la relación del patrimonio cultural y el paisaje con el agua, gracias a los cuales 
hemos aportado novedades a partir de la consulta de archivos públicos y privados, de la labor de campo y de la catalogación de numerosos elementos de este patrimonio, con ánimo de establecer líneas de investigación futuras.

Hemos agrupado los objetivos en cinco conjuntos para analizar la relación de determinados bienes histórico-artísticos y culturales sin aislarlos del ecosistema físico e histórico, que los liga al territorio y que lo vertebran, tal como se muestra por ejemplo en planos históricos, así como a un pasado cultural, a un medio ambiente y a una acción antrópica que se manifiesta en el arte, la ingeniería, la arquitectura, la geografía, la antropología, etc. Por eso, hablamos de patrimonialización del territorio.

El primero es el «Paisaje de la ingeniería», donde analizamos el patrimonio en relación directa con el cauce del río, la evolución de las infraestructuras y sus distintas tipologías: caminos históricos, puentes, carreteras, presas históricas y contemporáneas, molinos, aceñas; así como la labor desarrollada por los mecenas a lo largo de la etapa final de la Baja Edad Media, la Edad Moderna y la Edad Contemporánea. Mecenas como los concejos, la nobleza, los obispos. Un ejemplo es el conjunto de molinos y presas existentes en el arroyo del Morisco, en el término municipal de Garrovillas de Alconétar, muestra del aprovechamiento hidráulico de un río, o los puentes históricos de la cuenca del Tajo, como el de Jaraicejo o del Cardenal (que pasa parte del tiempo cubierto por las aguas del embalse de Alcántara, figura 4), el de Alcántara y el de Segura.

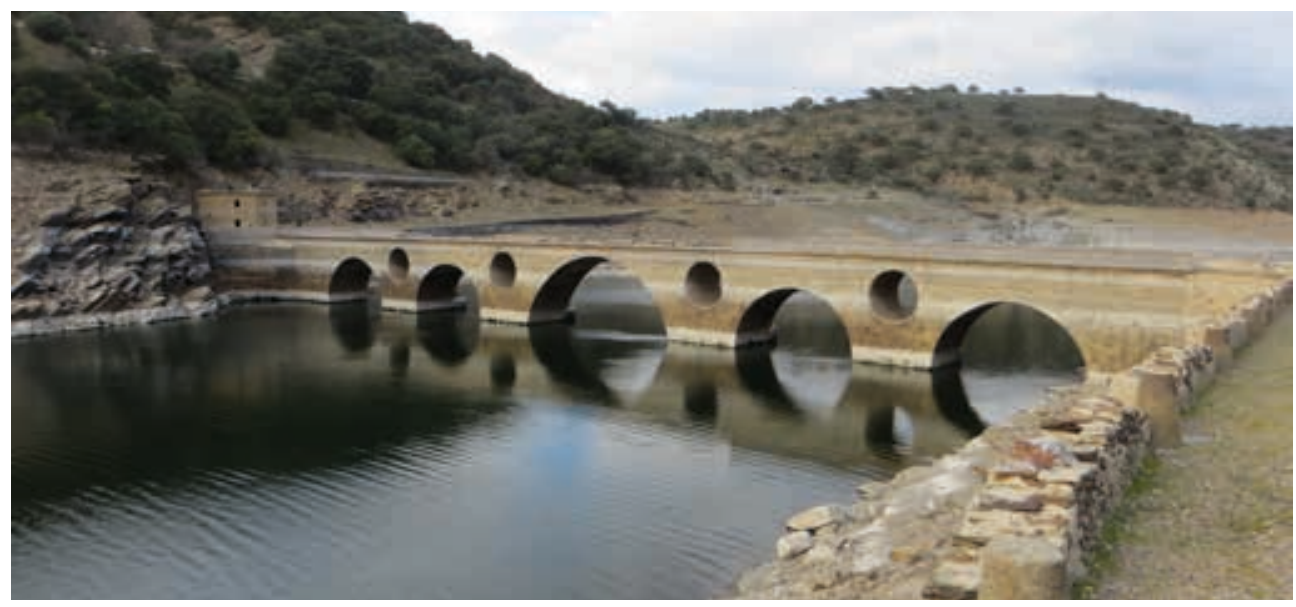

Figura 4. Puente del Cardenal sobre el río Tajo, en el parque de Monfragüe (siglos XV-XIX) (fotografía de M.a del Mar Lozano Bartolozzi) 
Algunos casos se han analizado tomando como referencia el reconocimiento que hizo el ingeniero y arquitecto militar Luis de Carducci, en 1641, y que compiló, en 1829, el militar Francisco Javier de Cabanes. Ambos trabajos, que presentan varios planos y están enmarcados en el estudio de la navegabilidad del río hasta Lisboa, han servido a Vicente Méndez para analizar los puentes desde la entrada del Tajo en Extremadura hasta el enclave de Alcántara y el conocido puente romano (figura 5), o el puente para el ferrocarril en el vado de Alconétar, de ocho vigas de celosías metálicas, construido por la compañía Eiffel en 1880 y que lamentablemente fue desmantelado. Hasta ahora no se conocía el proyecto original, pero ha sido documentado por el ingeniero Pedro Plasencia en un estudio donde se pone en evidencia que, para el propio Eiffel, se trataba de una de sus mejores obras (Plasencia, 2018).

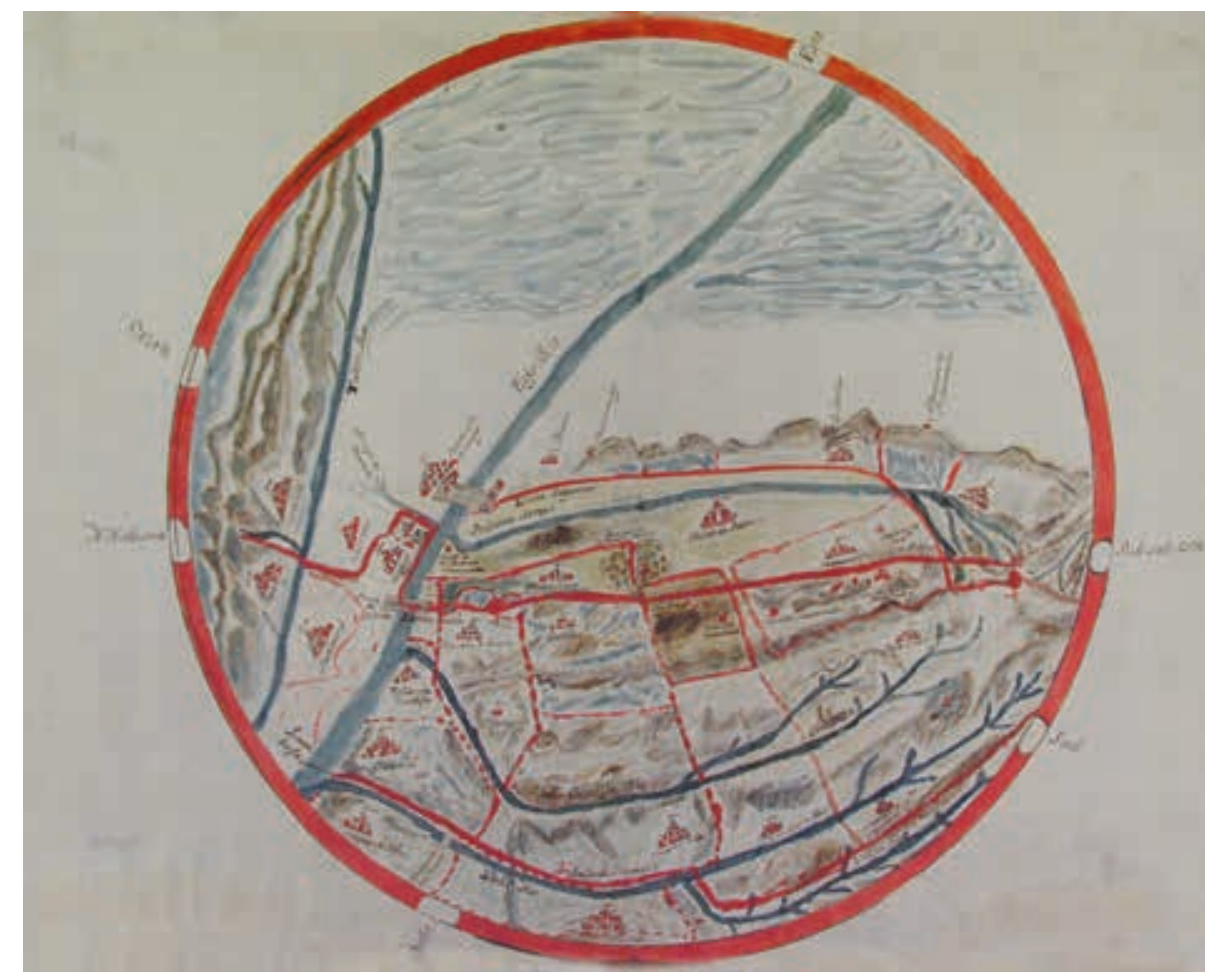

Figura 5. Mapa topográfico de las Villuercas, 1791-1820, tinta de colores. AHPCC, Real Audiencia, leg. 572, n. ${ }^{\circ} 34$ 
En el estudio de los caminos, destaca el que se restructura en el siglo XVIII desde el puente de Almaraz a Trujillo, analizado también por Vicente Méndez, que conocemos gracias a la cartografía histórica y sus anotaciones adjuntas. Previamente existían comentarios acerca del mal estado de dicho camino, por ejemplo, los del ministro Campomanes en su manuscrito relativo a su viaje a Extremadura. La obra fue proyectada por el ingeniero andaluz Dionisio Sánchez Aguilera, en 1764. En este proyecto también se propone la rehabilitación del puente que fue construido a mediados del siglo XV a instancias del obispo de Plasencia don Juan de Carvajal y fue reparado durante el reinado de Felipe IV entre 1635 y 1639.

Otro ejemplo de nuestros análisis son los poblados ferroviarios, varios de los cuales se sitúan en torno a la cuenca del Tajo, como el de Palazuelo-Empalme (hoy estación de Monfragüe), donde se producía el entronque entre las líneas férreas Madrid-Cáceres-Portugal y Plasencia Empalme-Astorga, a partir de 1896. El poblado fue realizado en las tres primeras décadas del siglo XX para habitación de los empleados de Renfe, con pabellones de viviendas de tres alturas de tipología uniforme definida por la Compañía de Explotación de los Ferrocarriles del Oeste de España. Se dotó de capilla-escuela, economato y consultorio médico. El poblado cambió el paisaje de dehesa de encinas y alcornoques con sus vías ferroviarias, sus túneles y sus construcciones, que pertenecen ya al patrimonio industrial (figura 6). La falta de necesidad de personal y el escaso servicio de este punto de entronque con la desaparición de la vía de Astorga han hecho que haya caído en desuso, se esté arruinando y se requieran alternativas para su recuperación, al no haberse llevado a cabo todavía un plan director que ya está redactado.

El segundo conjunto de estudio es los «Paisajes urbanos en el medio rural». En este apartado, estamos analizando los pueblos de colonización. Durante el franquismo, se constituyeron cerca de 300 pueblos en España a través de los planes de regadío del Insti-

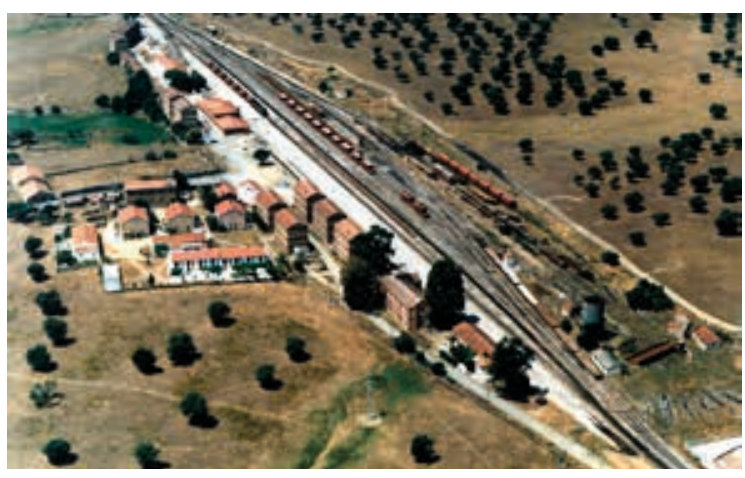

Figura 6. Poblado ferroviario de Monfragüe. Fotografía aérea (Centro de Conservación y Restauración de Bienes Culturales, Junta de Extremadura) 
tuto Nacional de Colonización, y en Extremadura se construyeron, entre 1951 y 1971, 64 de diferentes dimensiones y número de colonos: 38 en la cuenca del Guadiana (Plan Badajoz) y 26 en la cuenca del Tajo (Plan Cáceres), más algunas casas diseminadas. Nuestro equipo ha estudiado tanto los de la cuenca del Tajo en los valles del Alagón y del Tiétar, y en torno al río Valdesalor, como los de la cuenca del Guadiana.

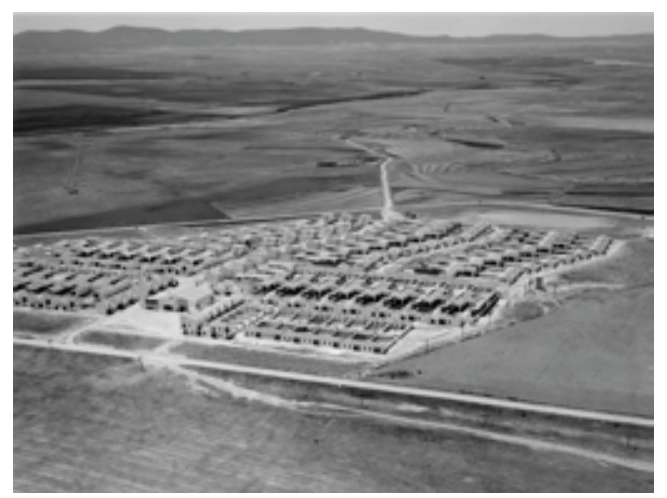

Figura 7. Valdesalor (Manuel Jiménez Varea, 1960). (C) Paisajes Españoles (1965)

Todos han supuesto una obra patrimonial de arquitectura, urbanismo y ordenación del territorio, transformado por la conformación de nuevos paisajes de regadíos, es decir, por la labor de antropización en el medio a tenor de la redistribución de la propiedad de las tierras, a excepción de Rincón de Ballesteros, que es un pueblo de secano. El estudio atiende a aspectos urbanísticos, arquitectónicos (recordemos algunos de los arquitectos que trabajaron en Extremadura: José Luis Fernández del Amo, Alejandro de la Sota, José Borobio, Carlos Sobrini, Rafael Leoz, Carlos Arniches, J. Antonio Corrales...), pero también al mobiliario urbano y, en particular, a sus iglesias debido al importante patrimonio de arte litúrgico contemporáneo que contienen, como han estudiado Miguel Centellas, Moisés Bazán y Esther Abujeta.

También hemos analizado los poblados de las presas y embalses, construidos ex novo para la producción de energía eléctrica, el abastecimiento y el riego. Algunos fueron poblados temporales levantados para los obreros que participaban en la construcción; otros eran poblados permanentes para los técnicos que debían mantener estas obras públicas. En su mayor parte, unos y otros han desaparecido o se encuentran transformados o en malas condiciones de conservación. Sin embargo, también en estas construcciones urbanísticas hechas en la naturaleza los arquitectos e ingenieros pudieron cumplir el reto de diseñar poblados ex novo, aunando estética y funcionalidad, y contribuyeron de forma significativa a introducir en Extremadura la arquitectura contemporánea y la relación con el paisaje. 
Se trata de poblados de interesante trazado y con singulares diseños arquitectónicos como los de Gabriel y Galán, obra de los ingenieros Manuel Caso Menac y Juan Bonilla (figura 8); el de Valdecañas, del arquitecto Fernando Urrutia Usuola; el de Torrejón, comenzado por él mismo, pero realizado por su colaborador Miguel de Oriol e Ybarra, que continuó las obras de la empresa hidroeléctrica tras el fallecimiento de Urrutia; más los tres poblados de Alcántara, de Oriol e Ybarra. En ellos se produjo el tratamiento de tipologías arquitectónicas según fueran casas destinadas a ingenieros, peritos, obreros, y se hizo en cada uno un centro cívico a veces con la tradicional plaza, capilla, escuela (o capilla/escuela), dispensario médico, cine/teatro, etc. La finalidad fue proporcionar una vida de calidad a personas desplazadas de sus hogares, con su familia o sin ella.

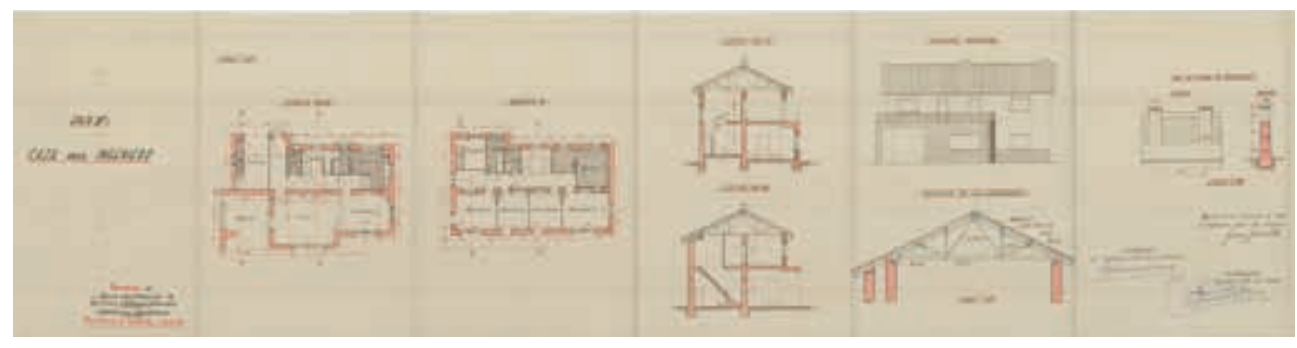

Figura 8. Proyecto Casa Administración, poblado de Gabriel y Galán, ingeniero Juan Bonilla, 1935, AGA. Sig. $24 / 14992$

El tercer conjunto analizado se denomina «El paisaje y las explotaciones agropecuarias», es decir, la arquitectura rural dispersa, analizada principalmente en trabajos de José Maldonado. Engloba las explotaciones agropecuarias, con sus linderos, la arquitectura civil de cortijos y casas de campo, y sus arquitecturas vernáculas, que van desde edificaciones y dependencias más rústicas a casas señoriales con jardines de recreo. Se han estudiado los propietarios históricos y el estado de transformación y conservación en las últimas décadas. Un paradigma es el conjunto de granjas y cortijos que fueron fruto de la política agropecuaria del monasterio de Guadalupe, en zonas entre los cauces del Tajo y el Guadiana, donde obtenían productos como aceite y vino al tiempo que servían de residencia de monjes e invitados. Después, fueron desamortizadas y adquiridas por particulares. Ejemplo de ello son las granjas de Mirabel y Valdefuentes (en la cuenca del Guadiana), la Casa de la Burguilla, el Caserío de Malillo o el Caserío de la Matilla de los Almendros (figura 9). 
Lamentablemente, algunas de las mejores actuaciones en el campo fueron luego mutiladas, como la casa de Antonio Garay o las Claverías, realizada por el arquitecto Manuel M. ${ }^{a}$ Smith e Ibarra en el término de Membrío, que se dejó con una sola planta, ya que las plantas superiores se eliminaron a fin de disminuir la imposición hacendística.

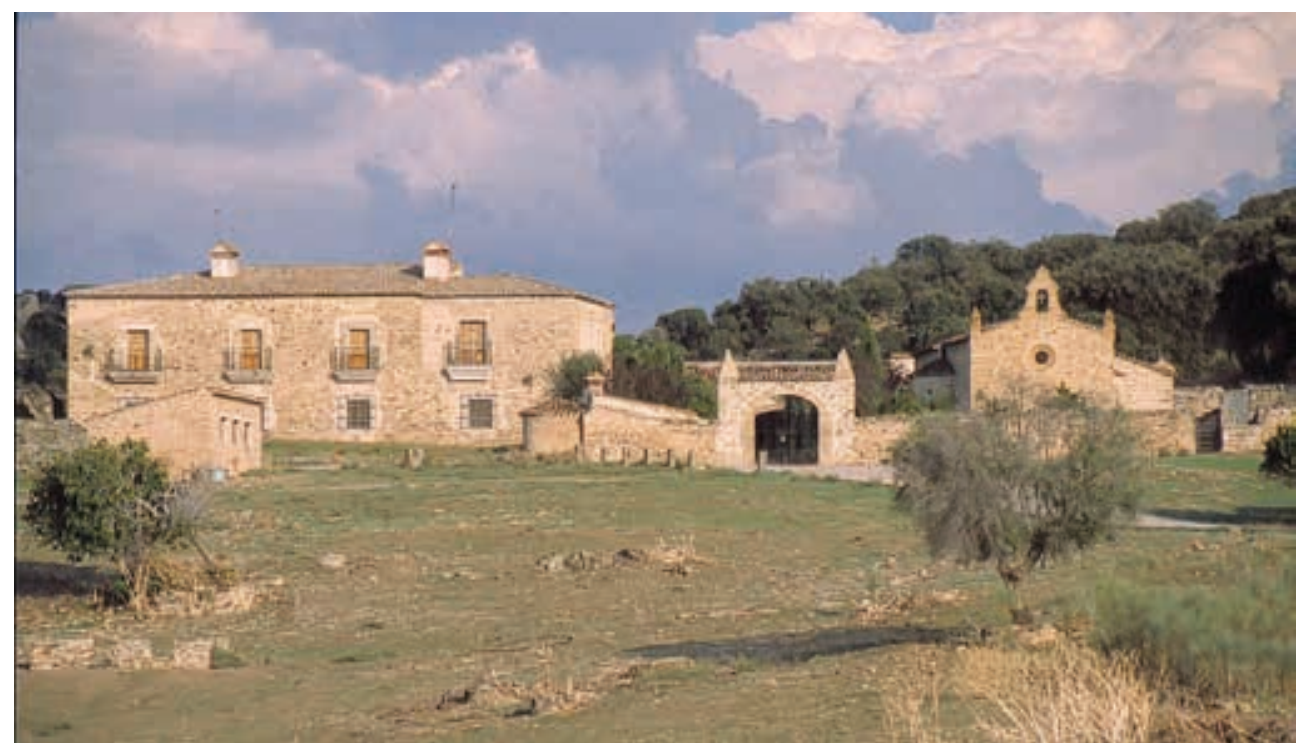

Figura 9. Caserío de Matilla de los Almendros, en Trujillo (fotografía cortesía de José Maldonado)

Muy singular fue un proyecto no realizado del vivero de Caparrosa, ideado por el ingeniero Diego Bordick en 1725, que consistió en un intento de replantación forestal para reparar las fortificaciones de la frontera luso-extremeña, muy dañadas por las repetidas guerras de los siglos XVII y XVIII. Se conservan los planos del lugar, el jardín y una edificación, que seguían modelos cortesanos de la época de Luis XIV. Este interesante trabajo ha sido publicado por la doctora Carmen Diez González.

En otro apartado, que hemos denominado «El paisaje de las creencias», se analizan paisajes transformados por la construcción de determinados inmuebles y la intervención en sus entornos de naturaleza, como fundaciones religiosas de las órdenes militares y monásticas, además de la construcción de ermitas con su implicación de la fe popular, abundantes en la cuenca del río Tajo. De algunas, por desgracia, solamente quedan ruinas. Un ejemplo de ello son los conventos 
franciscanos, con su elección de un determinado paisaje para conseguir un aislamiento que favoreciera las experiencias ascéticas y místicas de los frailes, que lograban así sus pequeños y particulares paraísos con la construcción, también, de eremitorios para la vida contemplativa. Estos han sido analizados por la citada doctora Carmen Diez, que ha documentado su arquitectura, huertas y jardines, y los ha relacionado con los recursos hídricos, y asimismo ha estudiado las fuentes, aljibes y canalizaciones, como el ejemplo de San Francisco de Belvís de Monroy (figura 10), donde se hizo un estudio topográfico de la zona, pues, además de convento, construyeron ermitas y equipamientos hidráulicos.

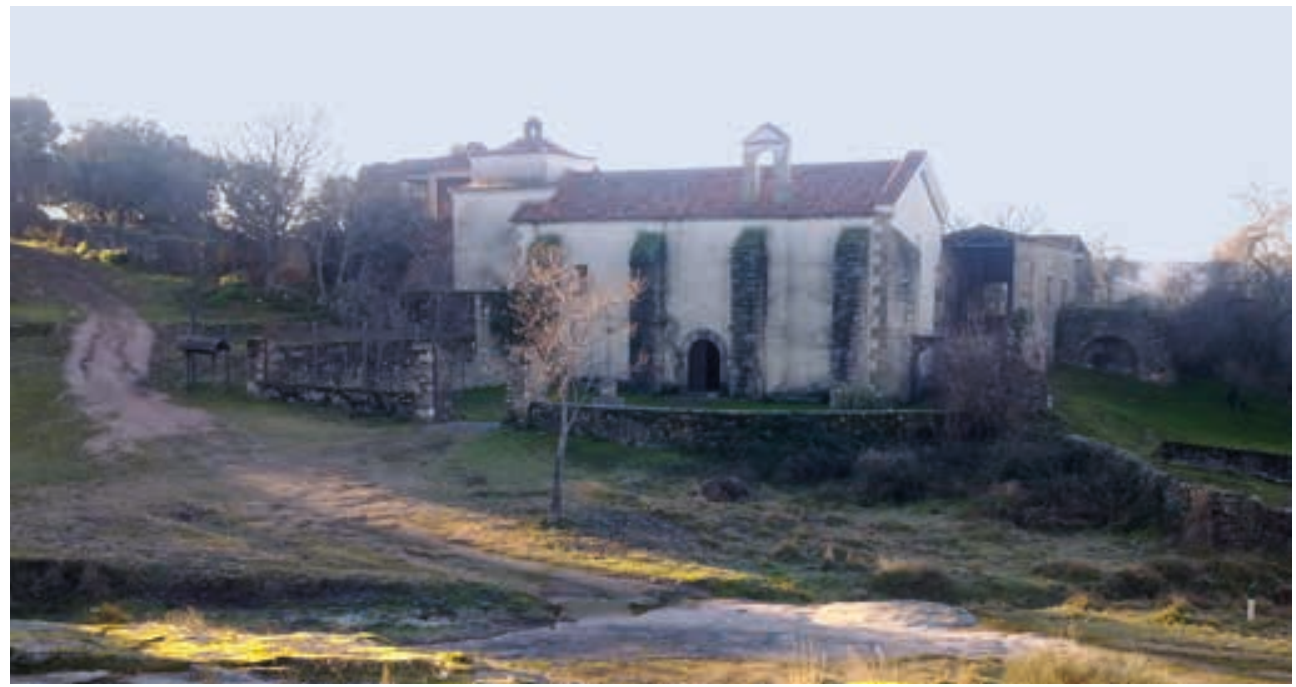

Figura 10. San Francisco de Belvís de Monroy (fotografía de M. a del Mar Lozano Bartolozzi)

En la misma línea, podemos citar el convento de San Pedro de los Majarretes, cercano a Valencia de Alcántara, fundado en el siglo XV y donde profesó San Pedro de Alcántara que, según comenta en sus estudios M. ${ }^{a}$ del Carmen Diez, es descrito así por un cronista:

Aunque su fundación es bien áspera, es muy diversible, por la variedad de plantas y silvestres arbustos, entre cuyas hojas y ramas se oyen en concertados gorjeos los cantos sonoros de las aves. Corren por el sitio límpidos arroyos, y liquidados cristales [...]. A trescientos pasos del convento nacen dos fuentes que alternando dulces correspondencias, la una corre en 
verano; y la otra concede sus aguas el invierno; una revierte con superabundancia desde la primavera al otoño; y la otra corresponde desde el otoño a la primavera. Llámanse estas fuentes de Malpica, cuya novedad por rara puede numerarla la naturaleza por uno de los partos de sus singulares maravillas. (Alcalá, 86-87)

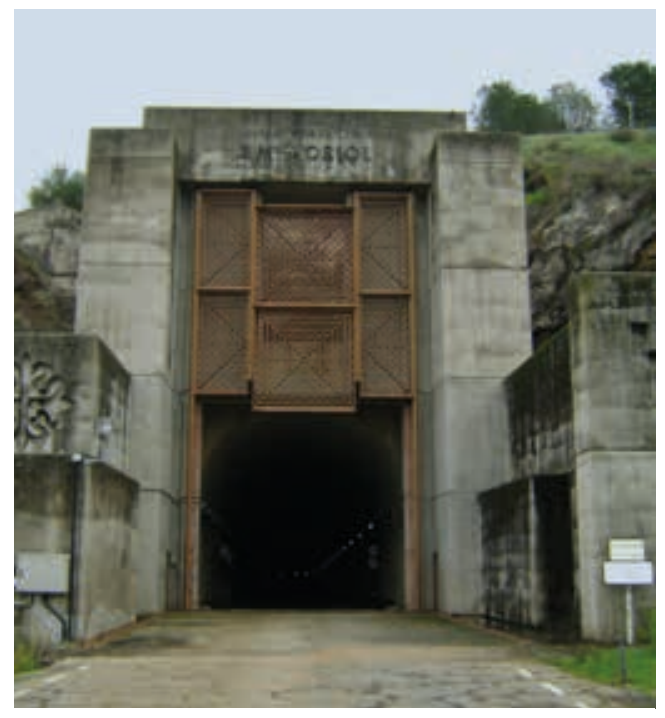

Figura 11. Puerta de la Central de Alcántara. Antonio Martínez Santonja, 1972 (fotografía cortesía del Archivo Iberdrola)

Para añadir uno más, citaremos el de San Martín de Trevejo, en la sierra de Gata, al abrigo de la sierra, entre viñedos, olivares, castaños y agua para su huerta y otros usos.

El quinto y último objetivo es: «Arte contemporáneo, naturaleza y sociedad». Dentro de él, hemos estudiado, principalmente Javier Cano y yo misma, las relaciones de algunos artistas contemporáneos con el agua y el paisaje en torno a las cuencas de los ríos. Además, se han analizado obras permanentes e instalaciones efímeras, como las esculturas de la central hidroeléctrica de Alcántara, del ingeniero y artista Antonio Martínez Santonja (figura 11), y de la presa de Valdecañas, de Venancio Blanco y Francisco López Hernández, o la importancia del río en la creación de nuevos imaginarios y referencias para una determinada iconografía en artistas pintores y grafistas. Desde autores como Sorolla, que pintó en Plasencia el río Jerte para el mural de la Hispanic Society de Nueva York dedicado a Extremadura; a las obras de artistas contemporáneos elaboradas en relación con el agua y la zona geográfica analizada, como la carpeta de serigrafías dedicada al monasterio de Yuste de Eduardo Naranjo, Mon Montoya y Javier Fernández de Molina. Por otro lado, José Manuel Ciria, un artista internacional, fue autor del proyecto pictórico: "Monfragüe: emblemas abstractos sobre el paisaje», por encargo del Museo Extremeño e Iberoamericano de Arte Contemporáneo de Badajoz (MEIAC); mientras que el artista caminante Fulton, inglés representante del land art que se vincula 
estéticamente con el paisaje cultural pero sin intervenciones en él, realizó en 2008 una caminata por Extremadura por encargo de la Fundación Ortega Muñoz, que desarrolla proyectos de arte y naturaleza en nuestra región, y plasmó dicha caminata en una serie de fotografías y en un libro de artista. A menudo sus citas se relacionan con la Vía de la Plata, el río Tajo, el Guadiana y las vivencias de pisar la tierra en un peregrinaje que a veces coincide con el de los pastores y rebaños.

Con respecto a la relación que ha establecido el ser humano con la naturaleza a través de la creación artística, la fundación de un museo por parte del artista alemán Wolf Vostell, en el año 1976, ha sido clave en nuestro territorio. Wolf utilizó unas antiguas instalaciones de unos molinos y un lavadero de lanas relacionado con la Mesta que están situados junto a una gran charca o laguna, en el paraje de los Barruecos, en Malpartida de Cáceres (Cáceres). El resultado es un ejemplo excepcional de arte y naturaleza. Un museo de arte fluxus, happening y ambientes; de los nuevos comportamientos artísticos de los siglos XX y XXI. En la colección están presentes artistas nacionales e internacionales, y con frecuencia se realizan exposiciones, performances e instalaciones, muchas de las cuales relacionan el arte con el agua y el paisaje. Un ejemplo fue la exposición Yoko Ono Tajo, de la artista japonesa fluxus afincada en Nueva York (figura 12).

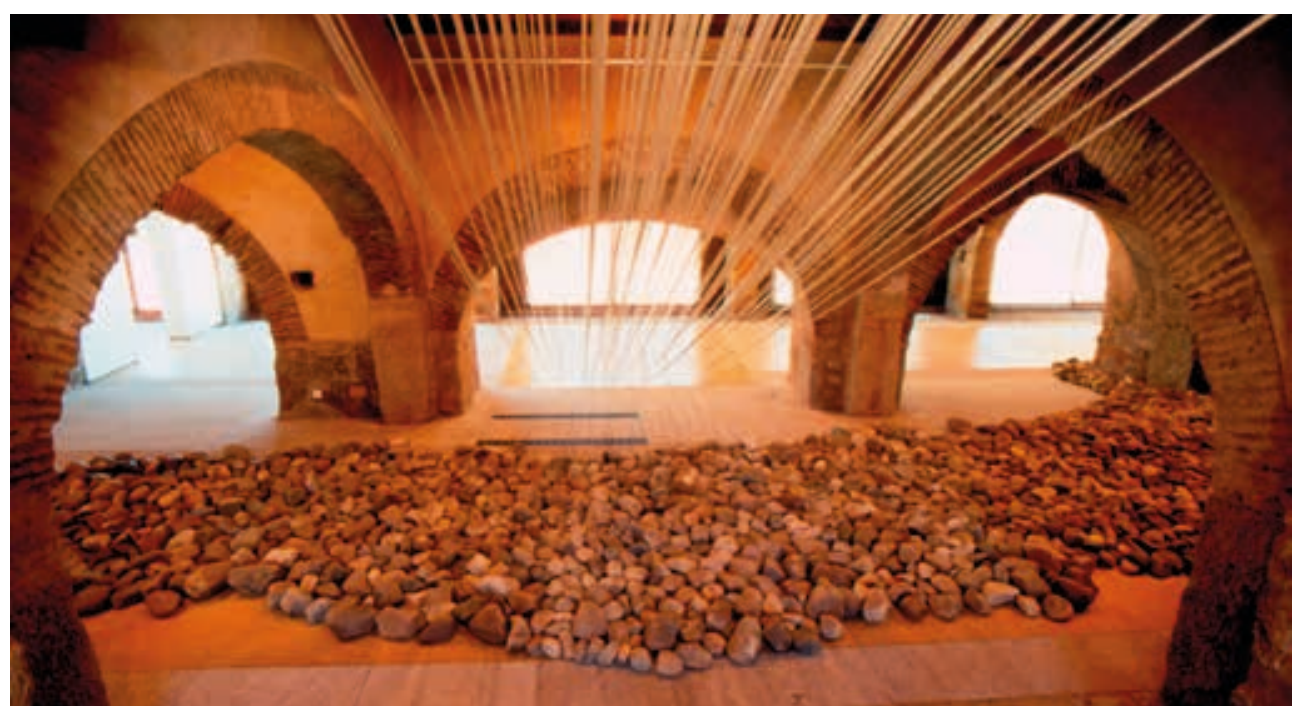

Figura 12. Riverbed ('Lecho del río'). Exposición Yoko Ono Tajo. Museo Vostell Malpartida, 2000 (fotografía cortesía del Archivo Happening Vostell Malpartida) 
Al respecto de la misma, el crítico de arte Jon Hendricks (Hendricks, 2000: 14) afirmó:

El título elegido para esta exposición, YOKO ONO TAJO, asocia a la artista con la fuerza vital de este río y su papel histórico como benefactor de todos aquellos pueblos a los que baña. El título es también una alusión a todos los ríos, a la constancia, al flujo y al cambio, al fluxus de nuestras vidas — renovación, alimento, fluir desde las fuentes hasta el mar, uniéndonos con frecuencia a otros en nuestros.

Sobre distintos aspectos del Museo Vostell Malpartida hemos investigado a lo largo de los proyectos Josefa Cortés y yo misma. Se añade la elaboración de la Tesis Doctoral de Marina Bargón García, que ha sido Becaria FPI del tercer proyecto, titulada: Del mundo mineral al mundo animal. Wolf Vostell y la utilización de la naturaleza en obras de arte intermedia, presentada en diciembre de 2019.

Como conclusión, consideramos que estos análisis del patrimonio de las riberas del Tajo pueden aportar: el conocimiento y el inventario de unos bienes observados en su contexto territorial, histórico y medioambiental, es decir, dentro de los paisajes culturales que han configurado y no de forma aislada; un conocimiento acompañado de un breve diagnóstico sobre el estado de conservación y su actual situación de sostenibilidad. El análisis de tales paisajes es una buena herramienta para su planificación y gestión, para tomar medidas integradoras de carácter territorial y estrategias de mejora en el futuro. Ponemos estos conocimientos a disposición de las administraciones responsables que financian estos proyectos para que lo tengan siempre en cuenta, pues lamentablemente muchos de los trabajos de investigación no son considerados por los propios poderes públicos que los promueven.

Debemos decir que se está avanzando en la valoración de bienes que hasta hace poco tiempo no eran considerados como tal. Un ejemplo de ello es la declaración de Bien de Interés Cultural en el año 2017, tras la investigación realizada por el doctor arquitecto de la Universidad de Extremadura José Carlos Salcedo, del sistema de abastecimiento hidráulico del monasterio de Guadalupe, con elementos como el arca del agua, situada a $6 \mathrm{~km}$ de la población, que fue construida en el año 1350 y conserva su uso.

En segundo lugar, se han hecho algunas propuestas ambiciosas de conservación y gestión, con reflexiones teóricas y técnicas, como la propuesta de ordena- 
ción territorial del vado de Alconétar, en el entorno del embalse de Alcántara, que ha sido realizada por el investigador Pedro Plasencia y que es un modelo de musealización y desarrollo sostenible de esta zona y su patrimonio. En ella se propone la puesta en valor de los elementos construidos de distintas civilizaciones (dólmenes, puentes, presas, molinos, ermitas cercanas, un castillo, viaductos contemporáneos, etc.), con lugares de paisajes preferentes, pero también la regeneración del paisaje, con la densificación mayor del arbolado, las plantaciones de viñedos para su explotación y la construcción de ecoaldeas para uso turístico. Se añaden dotaciones para el deporte, un centro de interpretación del patrimonio sumergido, vías de tránsito para bicicletas, actuaciones de land art, etc. De esta manera, se busca conservar los bienes, pero también tutelarlos, con la implicación de los usuarios, en una sostenibilidad ambiental y local (figura 13). Su finalidad es, según el proponente: la protección del patrimonio, un uso eficaz y sostenible del suelo, la conservación de la identidad para los habitantes, la protección del medio ambiente y la puesta en valor de un paisaje cultural asociado al «construir».

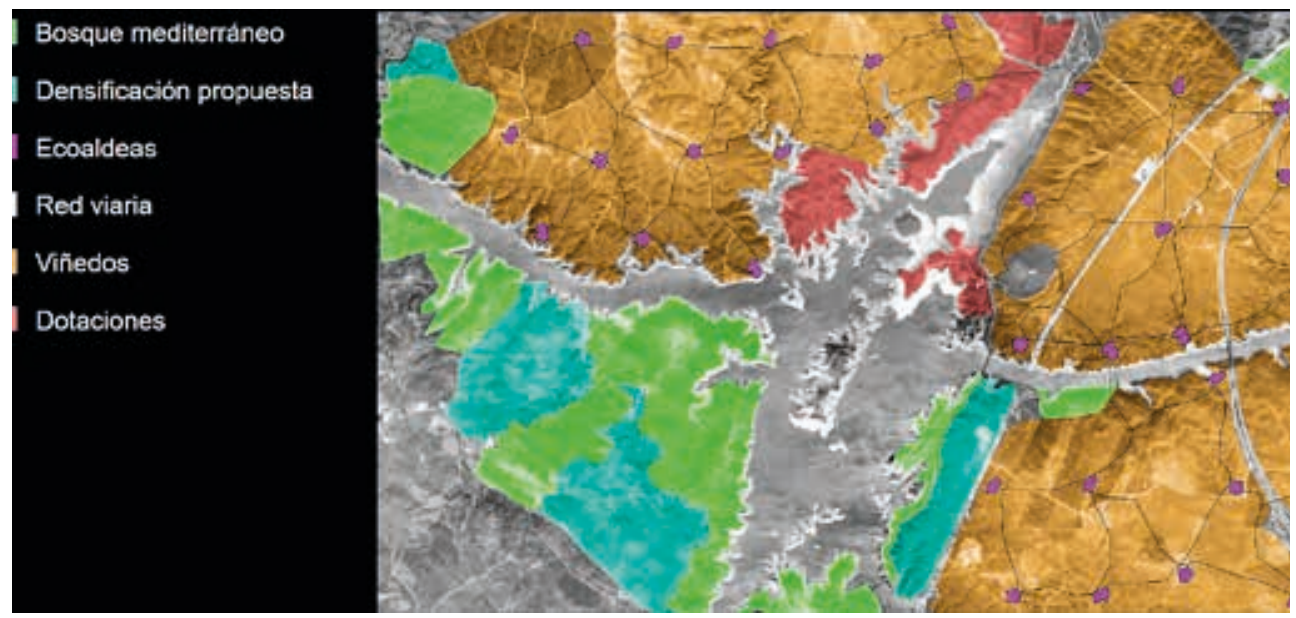

Figura 13. Propuesta de ordenación territorial del vado de Alconétar (Pedro Plasencia)

Además, se ha propuesto el diseño de una ruta turístico-cultural por los pueblos de colonización del valle del río Alagón, nunca planteada hasta ahora, que implica transferencias concretas de aplicación para revitalizar la zona. La concienciación de los alcaldes de los pueblos y sus vecinos para conservar dicha arqui- 
tectura y sus trazados, sin impedir las mejoras necesarias acordes con la sociedad actual, es otra labor que nos ha preocupado desde el principio.

No olvidamos tampoco que la Administración tiene en marcha programas de desarrollo de algunas de estas zonas, como el de cooperación transfronteriza con la marca Tajo Internacional I y II, para la promoción de productos turísticos como la navegación del río Tajo y sus afluentes, tanto por Extremadura como por Portugal, o el del Geoparque Villuercas-Ibores-Jara, creado en 2009, que forma parte de la Red Europea de Geoparques y ha sido reconocido por la Unesco como geoparque mundial con la green card o tarjeta verde que otorga la organización en el año 2015. En este parque se celebran muchas actividades educativas, científicas, turísticas, gastronómicas, artísticas y culturales. Entre otras, se promueve la feria de ornitología de Monfragüe, las visitas a sus abrigos de pinturas esquemáticas, etc.

Debemos decir además que la Administración autonómica se ha implicado actualmente en la catalogación y concienciación social de los pueblos de colonización, con acciones como el congreso del Docomomo Ibérico, celebrado en el mes de mayo de 2018 en Badajoz en colaboración con el Colegio de Arquitectos y que tuvo como tema prioritario los citados pueblos, y con su catalogación, adjudicada mediante concurso, con una documentación exhaustiva que ha sido ya finalizada, donde también han participado investigadores del grupo. A ello se añaden acciones de concienciación en los propios pueblos con la colaboración de algunos ayuntamientos, pues es necesario que cualquier medida pase por un proceso pedagógico destinado a los protagonistas, es decir, a los habitantes que se sientan implicados. Estas y otras acciones conforman una parte sustancial de las DOTEX (Directrices de Ordenación Territorial de Extremadura).

Para terminar, nuestra experiencia nos hace afirmar que, en cualquier actuación de conservación de un paisaje cultural que afecte a poblaciones y territorios, se debe utilizar el análisis histórico cultural con nuevas miradas a la luz de las cartas y reuniones internacionales como primera herramienta de gestión, pero además deben estar implicadas las autoridades políticas, alcaldes, empresarios, más los grupos de acción local y los propios vecinos de los municipios o propietarios de los terrenos rústicos. 


\section{REFERENCIAS BIBLIOGRÁFICAS}

Abujeta Martín, Esther (2016): Intervención en el patrimonio arquitectónico extremeño: la red de hospederías, tesis doctoral, Universidad de Extremadura.

AlCalÁ, Marcos de (1736-1738): Chronica de la Santa Provincia de San Joseph, de N. P. S. Francisco, Madrid, Manuel Fernández, vol. 1, 131-132.

Andrés Ordax, Salvador (dir.) et al. (2007): Monumentos artísticos de Extremadura, Badajoz, Editora Regional de Extremadura, Dirección General de Bibliotecas, Museos y Patrimonio Cultural, Junta de Extremadura.

BARgón GARCía, Marina (2020): Del mundo mineral al mundo animal. Wolf Vostell y la utilización de la naturaleza en obras de arte intermedia, Tesis doctoral, Universidad de Extremadura.

Bazán de Huerta, Moisés / Vicente Méndez Hernán (coords. y eds.) (2019): Paisajes culturales en la Extremadura meridional. Una visión desde el patrimonio, Cáceres, Universidad de Extremadura.

Cano Ramos, José Javier (dir.) et al. (2016): Paisajes culturales de Extremadura I, Badajoz, Dirección General de Bibliotecas, Museos y Patrimonio Cultural, Junta de Extremadura.

Cano Ramos, José Javier / Nuria M. Franco Polo (coords. y eds.) (2017): Paisajes culturales de Extremadura II, Badajoz, Dirección General de Bibliotecas, Museos y Patrimonio Cultural, Junta de Extremadura.

Cano Ramos, José Javier / Nuria M. Franco Polo (coords. y eds.) (2019): Paisajes culturales de Extremadura III, Badajoz, Dirección General de Bibliotecas, Museos y Patrimonio Cultural, Junta de Extremadura.

Cerrillo Martín de Cáceres, Enrique / Ana Montalvo Frías (2008): La Vía de la Plata. Una calzada y mil caminos, Madrid, Sociedad Estatal de Conmemoraciones Culturales.

Collado Giraldo, Hipólito / José Julio García Arranz, (coords.) (2005-2017): Corpus de arte rupestre en Extremadura, vols. I, II, III, IV, Mérida, Editora Regional de Extremadura.

Cruz Pérez, Linarejos (coord.) (2015): 100 paisajes culturales en España, Madrid, Ministerio de Educación, Cultura y Deporte.

Diez González, María del Carmen (2018): «Plantaciones de árboles madereros con usos militares en Extremadura: el sesmo de Caparrosa en Valencia de Alcántara (Cáceres), un proyecto de Diego de Bordick», Liño: Revista Anual de Historia del Arte, 24, 59-72.

Hendricks, J. (2000): «Yoko Ono Ebro/Tajo», en Yoko Ono / P. J. Rico / J. Hendricks, Yoko Ono Tajo, [Mérida], Consejería de Cultura de la Junta de Extremadura / Consorcio Museo Vostell Malpartida.

Lozano Bartolozzi, M. ${ }^{a}$ del Mar / Javier Cano Ramos (2012): «Construcciones que miran al agua. Espejos patrimoniales en un paisaje intervenido por el Tajo», e-rph, Revista Electrónica de Patrimonio Histórico, 10, Universidad de Granada, 1-9.

Lozano Bartolozzi, María del Mar / Vicente Méndez Hernán (coords. y eds.) (2012): Paisajes modelados por el agua: entre el arte y la ingeniería, Cáceres, Editora Regional de Extremadura.

Lozano Bartolozzi, María del Mar / Vicente Méndez Hernán (coords. y eds.) (2014): Patrimonio cultural vinculado con el agua. Paisaje, urbanismo, arte, ingeniería y turismo, Cáceres, Editora Regional de Extremadura.

Lozano Bartolozzi, María del Mar / Vicente Méndez Hernán (coords. y eds.) (2017): Paisajes culturales del agua, Cáceres, Universidad de Extremadura.

Lozano Bartolozzi, María del Mar / Vicente Méndez Hernán (coords. y eds.) (2018): Paisajes culturales entre el Tajo y el Guadiana, Cáceres, Universidad de Extremadura.

Plasencia-Lozano, Pedro (2018): «El puente sobre el Tajo de Eiffel en España», Informes de la construcción, vol. 70, n.o 551 (julio-septiembre de 2018). 



\section{EL PATRIMONIO CULTURAL DE LOS RIOS EN LAS DIRECTRICES DE ORDENACIÓN DEL TERRITORIO DE VALLADOLID Y SEGOVIA}

Juan Luis de las Rivas Sanz

Arquitecto, profesor de Urbanismo

Escuela de Arquitectura de la

Universidad de Valladolid

DOI: 10.17075/pvpcr.2021.003 



\section{SOBRE LA PUESTA EN VALOR DEL PATRIMONIO CULTURAL DE LOS RÍOS}

La invitación del Consello da Cultura Galega para participar en las jornadas «A posta en valor do patrimonio cultural dos ríos: Galicia e outros exemplos», gracias al profesor Carlos Nárdiz, me ofrece la oportunidad de ordenar de manera sencilla algunas ideas. Comparto con Carlos una misma visión territorial del urbanismo. La dimensión espacial de los fenómenos urbanos no tiene explicación si se aborda exclusivamente desde el artefacto ciudad. No me refiero exclusivamente a contextualizar, a explicar la geografía concreta en la que lo urbano «tiene lugar»: la morfología de la ciudad, su arquitectura en sentido amplio, es incomprensible sin su territorio, tanto físico como histórico. Llevo ya tiempo tratando de defender la idea de que el único enfoque para reconocer la estructura de la ciudad contemporánea es paisajístico. En un contexto de metropolización del territorio, tras largos años de urbanización sistemática, hoy parece inviable que la ciudad pueda ser reconocida desde su forma y, por ello, se cuestionan las herramientas convencionales de planificación. Lo apuntaba ya a finales del pasado siglo F. Choay (1994) ${ }^{1}$ : "la ciudad se confunde en lo urbano»; y lo apuntaron nuevas categorías interpretativas en contextos diferentes, pero con elementos comunes, como metápolis, edge city, urban fringe, ciudad difusa..., categorías explicativas que, sin embargo, no ofrecían una salida concreta a la planificación, no la dotaban de una narrativa capaz de describir con coherencia el puzle urbano, sus lógicas configuradoras.

No se puede «ordenar» lo que no se sabe interpretar correctamente. Es necesario modificar la perspectiva con la que abordamos lo urbano, redescubriendo su dimensión regional, reenfocando el estudio de la morfología urbana desde su estructura geográfica, reaprendiendo a jugar con las escalas para interpretar el complejo puzle espacial de la ciudad contemporánea. Para ello, es imprescindible un enfoque paisajístico que permita construir una narrativa diferente sobre la forma urbana, a la vez cultural y técnica. No se trata de un problema instrumental ni de una cuestión tecnológica, de SIG o de big data. Se trata de «re-conocer» la dimensión espacial del entorno construido en su intensa interacción con el

1 Françoise Choay es pionera en mostrar la ciudad contemporánea como una realidad sin forma reconocible y lo urbano como un conjunto de fenómenos contiguos difícilmente explicables (Choay, 1994). 
espacio no construido para recomponer con coherencia una interpretación del mosaico urbano. El soporte físico de la vida urbana, tanto su estructura básica como las formas que caracterizan cada modo de urbanización, necesita una explicación que se apoye, de nuevo, en la geografía y en la historia. Decir paisaje significa reivindicar, más allá del análisis funcional, del estudio de localización de actividades, de centralidades y flujos, la explicación cultural de lo urbano (De las Rivas, 1996, 2001, 2006, 2013)².

En todo ello, la cuestión de los cursos de agua adquiere una relevancia capital, más intensa si cabe en las ciudades de interior, alejadas de la costa, aunque también en las costeras. En mi primer trabajo relevante, las Directrices de Ordenación Territorial de Valladolid y Entorno ${ }^{3}$, el relieve y los cursos de agua nos ofrecieron una oportunidad para comprender un espacio metropolitano en formación confuso, con más de $900 \mathrm{~km}^{2}$ y 23 municipios alrededor de la capital castellana. Es algo que, personalmente, había descubierto en una estancia en la Arizona State University, leyendo allí a Ian McHarg, a R. T. Forman y a F. Steiner ${ }^{4}$, pero también lo aprendí entonces en la explicación de la geografía del «solar vallisoletano», de Jesús G. ${ }^{a}$ Fernández, y más tarde confirmé estas perspectivas desde su articulación cultural con Vittoria Calzolari y su lectura paisajística de las ciudades mediterráneas (De las Rivas, 2012).

Como se verifica en las figuras 1 a y $1 \mathrm{~b}$, el conjunto diverso de los cursos de agua (ríos, arroyos y canales) establece el sustrato físico del espacio habitado y define los espacios naturales y agrarios más valiosos, verdadero esqueleto del territorio. Un espacio de encrucijada que hace accesible la visión coherente del sistema urbano, imposible si la narración comienza en lo urbanizado. El pai-

2 Lo intenté por primera vez, gracias a Javier Maderuelo, en «La naturaleza en la ciudad-región: paisaje, artificio y lugar» (De las Rivas, 1996), un tema que he ido retomando una y otra vez, evolucionando hacia un concepto integrador del paisaje.

3 He tenido la oportunidad de colaborar en experiencias pioneras de planificación regional en Castilla y León dirigiendo diversos trabajos en el Instituto Universitario de Urbanística. El primero de ellos, las Directrices de Ordenación Territorial de Valladolid y Entorno (aprobadas en 2001), recibió en 2002 el 4. ${ }^{\circ}$ Gran Premio Europeo de Planificación Regional y Urbana, concedido por el Consejo Europeo de Urbanistas (European Council of Town Planners, ECTP) (De las Rivas, 2010).

4 Allí, Fritz Steiner, muy próximo a Ian McHarg, e Ignacio San Martín, pionero de la lectura ecológica del diseño urbano, me habían introducido en una cultura paisajística nueva para mí. Luego hicimos un esfuerzo para traducir y editar en castellano «Design with nature» (De las Rivas, San Martín y Steiner, 2000). 
saje, su esqueleto de agua, es el primer paso para dar cuenta del poblamiento, desde los núcleos históricos a lo urbano contemporáneo, y de la estructura de comunicaciones (carreteras y ferrocarriles, pero también la morfología urbana más menuda) que no puede renunciar a su lógica adaptativa, al relieve y a los cursos fluviales.

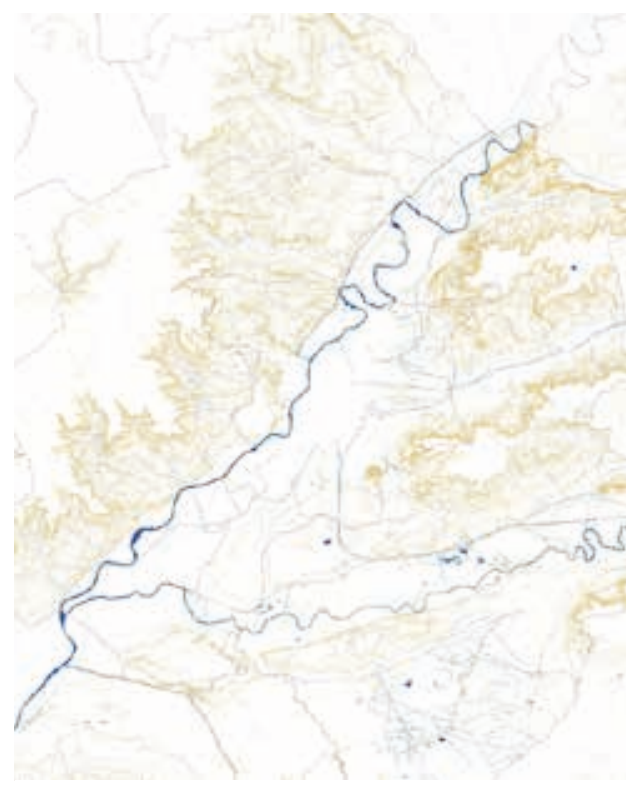

Figura 1a. Los cursos de agua en el enclave de Valladolid. Fuente: IUULab, 2006

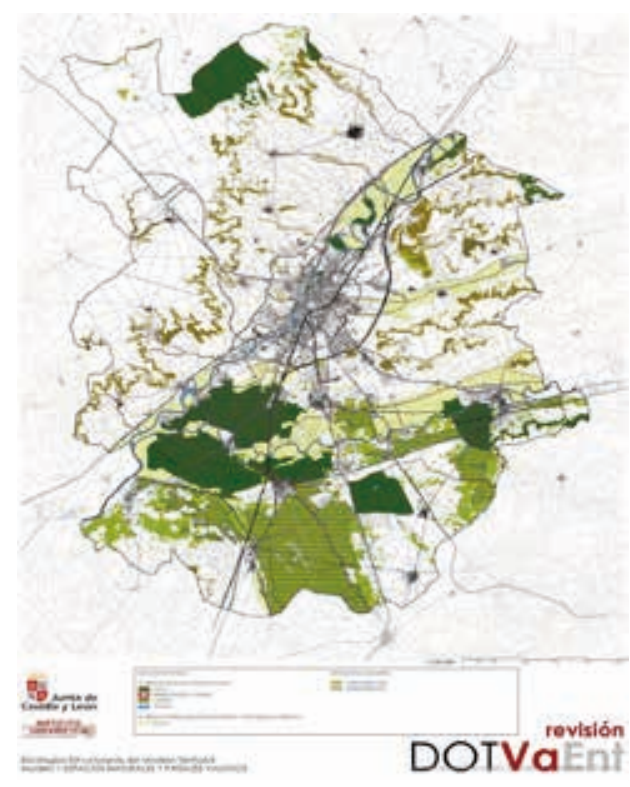

Figura 1b. Sistema de espacios de singular valor ecológico. Fuente: IUULab, DOTVAENT, 2006

\section{VALLADOLID, TIERRA DE AGUAS}

Si lo que nos interesa es la dimensión cultural o patrimonial de los ríos, cabría pensar que en Valladolid lo más relevante es el Canal de Castilla, una joya de la ingeniería hidráulica de la Ilustración, o los viejos puentes sobre el Pisuerga y el Duero, o los vestigios que todavía quedan de aceñas, pesqueras y tenerías. Sin embargo, el principal valor cultural de los ríos es el propio paisaje, un paisaje antrópico tanto en las riberas como en los pinares o en los espacios agrarios, que da forma también a lo urbano. Valladolid es una tierra de aguas. Es la ciudad del Pisuerga, pero antes del Esgueva y del Duero, ya que en el área urbana desemboca 
el propio Pisuerga, pero también el Adaja y el Cega. Y es una ciudad de canales: el Canal de Castilla y el canal del Duero; este último, con un amplio sistema de acequias, define el paisaje del este de la ciudad, penetrando en ella. Sin embargo, es peor un paisaje escondido, en gran medida minusvalorado, pero dotado de un extraordinario potencial no solo porque, gracias a los cursos de agua, la ciudad y su entorno son espacios fértiles, espacios verdes, sino porque provee a la ciudad de un soporte natural y cultural creador de calidad urbana.

La explicación etimológica de Valladolid, por diversos caminos, converge en la presencia del agua, ya sea como valle de aguas o como lugar de lagunas. La toponimia siempre nos asiste, porque el secreto de la ciudad situada en el corazón de la meseta norte reside en la diversidad y complejidad de su estructura hidrográfica, sobre un sustrato geológico sencillo y en un paisaje austero, donde la abundancia de agua corrige los efectos de un clima seco. La encrucijada de cursos fluviales horada su soporte geológico plano y hace posible una fisiografía variada y una vegetación muy antropizada en la que predominan riberas, campiñas agrarias y pinares.

Los grandes temas de la ecología de los espacios abiertos, urbanos y periurbanos, orientan las Directrices y estructuran nuestros trabajos del Avance del Plan General de Valladolid en 2012-13: primero los sistemas de parques, los corredores verdes y la agricultura periurbana; después, con una reflexión más compleja de los corredores ecológicos, el potencial de la infraestructura verde y la perspectiva que introducen los servicios de los ecosistemas en el conjunto de los espacios abiertos. No obstante, más allá de uno u otro enfoque, la directriz espacial permanece en la capacidad estructurante de los cursos de agua: el valle del Pisuerga, la espina dorsal norte-sur de Valladolid, en el norte penetra a la par que el Canal de Castilla; al sur se encuentra el valle del Duero, que recibe en Simancas al Pisuerga, pero que en la ciudad se articula hacia el este con el canal del Duero, combinado con el Esgueva, que define un corredor este-oeste. Pisuerga, Esgueva y Duero orientan las tres grandes cuñas verdes que arman el paisaje del área urbana.

Hablamos de componentes del paisaje que ofrecen en Valladolid posibilidades apenas desplegadas. De hecho, las mentalidades locales y regionales no parecen preparadas todavía para habilitar con ello estrategias innovadoras; así lo demuestra la permanente falta de perspectiva tanto sobre los cursos de agua como conjunto, como sobre los paisajes agrarios periurbanos (figuras $2 \mathrm{a}$ y 2b). Las Directrices peligraron a finales del pasado siglo, antes de ser aprobadas, por la dificultad 
que implicaba proteger los paisajes agrarios. No se entendía el valor ecológico del mosaico de vacíos y llenos en las franjas de borde de los espacios urbanizados, que ya entonces se defendían en otros contextos (en los que recibían el nombre de urban fringe belts) y que considerábamos un recurso ecológico, además de una necesidad para una ciudad sometida a las tensiones del «todo es urbanizable». De hecho, y aun cuando el Pisuerga y el Esgueva se reconocen con claridad en el modelo urbano vigente, el Canal de Castilla y el canal del Duero permanecen casi escondidos, y el énfasis en la riqueza y potencialidad de las vegas, reactivando usos agrarios en bordes y vacíos urbanos, parece una quimera.

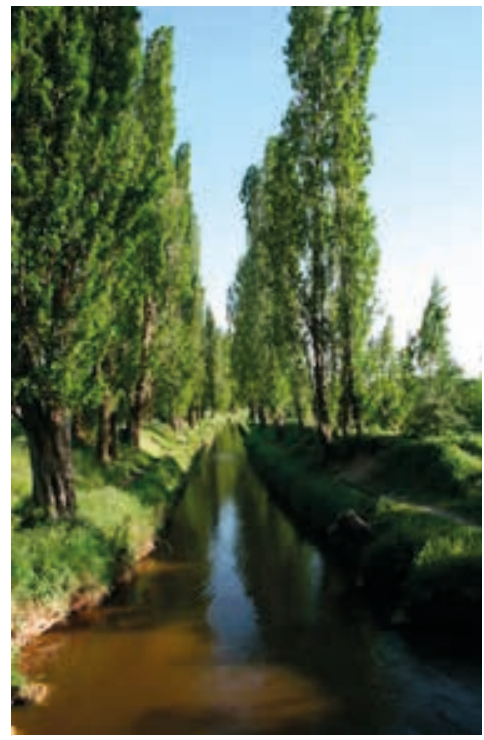

Figura 2a. Acequia del canal del Duero en los alrededores de Valladolid

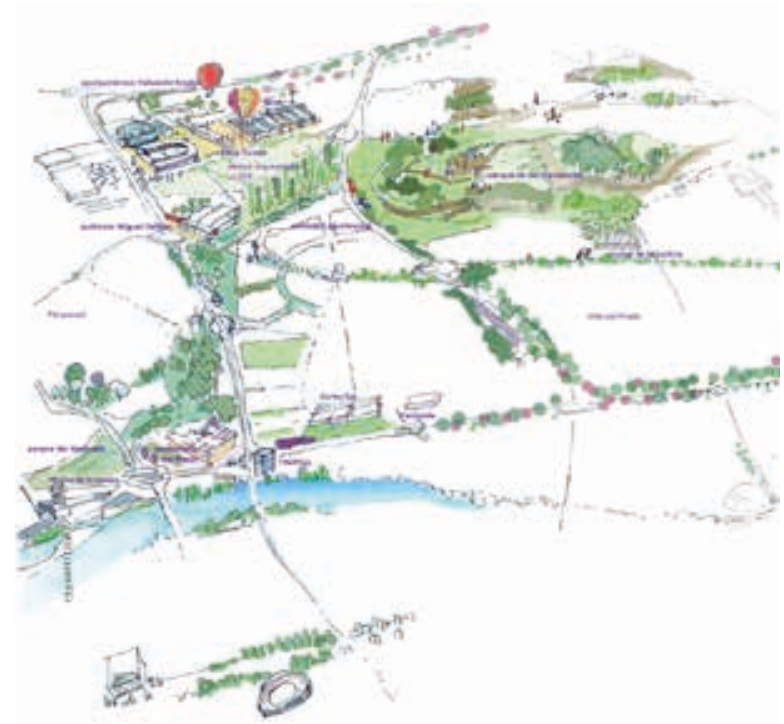

Figura 2b. Sistema de parques, continuidad de espacios libres con vegetación. Fuente: IUULab, Avance PGOU Valladolid, 2016

El trabajo en Valladolid nos ha convencido, sin embargo, de la capacidad que tiene una aproximación integrada a la naturaleza, al paisaje de la ciudad-región, para abordar el patrimonio local desde una perspectiva sistémica, necesaria si aspiramos a una defensa más coherente de los paisajes culturales locales y de su soporte natural (Hough, 1998; Forman, 2010). En Valladolid, los cursos de agua son el hilo conductor imprescindible. 


\section{EL VALLE DEL ERESMA EN SEGOVIA, MÁS ALLÁ DEL PAISAJE URBANO HISTÓRICO}

Naturaleza y cultura materializan en Segovia un paisaje cultural excepcional en el que, de nuevo, los cursos de agua son un hilo conductor imprescindible. El paisaje de Segovia surge y se despliega en el cruce de dos ríos, el Eresma y el Clamores, tanto sobre el promontorio del recinto amurallado, cuyo eje es el canal madre que surge del acueducto (el tercer río), como sobre los valles y vegas.

Me centro en el valle de Eresma a lo largo de la ciudad de Segovia, un espacio muy particular al estar poblado por una diversidad compleja de asentamientos de origen y valor histórico: poblaciones agrarias, como San Lorenzo, o ganaderas, como San Marcos, y vestigios de batanes a lo largo del río, ligadas a un pasado industrial de molienda del cereal y trabajos en paños; instalaciones singulares como la Casa de la Moneda, y una rica serie de monasterios, conventos y eremitorios extramuros, desde San Vicente a El Parral y La Fuencisla. Todo ello a lo largo del valle, tras el encuentro del arroyo Cigüeñuela con el Eresma, y al pie del lienzo norte de la muralla, entre el acueducto y el alcázar, en medio de huertas, paseos arbolados y jardines. El río es el alma de un sistema complejo de espacios que solo desde la lógica del valle puede ser integrada y comprendida como un todo.

La historia de la planificación urbana en Segovia, en particular en el Eresma, permite dar cuenta de una tradición de valoración y respeto de su paisaje. Ya de forma muy pionera, poco después de que el conjunto de la "ciudad antigua» fuese declarado monumento, en 1941, mediante un documento asociado de protección de vistas, el conjunto de huertas y arboledas que circunda la ciudad amurallada, a lo largo del Eresma y el Clamores, es protegido en 1947 como Paraje Pintoresco. Segovia cuenta así con una herramienta que hace posible que las riberas y valles interiores se conserven. De hecho, podemos encontrar algunos espacios dotados de una extraordinaria estabilidad más allá del paso del tiempo, como se comprueba si comparamos la vista del valle del Eresma que hace Alfred Guesdon en 1854, desde La Fuencisla y hacia el alcázar, y sobre Veracruz y el convento de San Juan de la Cruz, con la vista actual (De las Rivas, 2009). Esta cultura de salvaguardia se mantiene en el tiempo. Así, cuando a finales del pasado siglo tuvimos la oportunidad de elaborar el Plan 
Especial de Protección del Valle del Eresma, San Lorenzo y San Marcos, fue posible pensar en el valle como un conjunto completo articulado por el Eresma, gracias al Plan General que años antes habían elaborado para la ciudad Javier de Mesones y Adriana Dal Cin, quienes definieron un conjunto de ámbitos históricos complejos y coherentes de planificación espacial protectora. Aunque no desarrollaron dichos planes, y de esta forma dejaron pendiente de ordenar la mayor parte de la ciudad, la más compleja, tomaron algunas precauciones entonces extraordinarias, como clasificar las huertas del Eresma como «suelos no urbanizables protegidos», en el corazón de la ciudad consolidada. Ello era sin duda un esfuerzo de continuidad con aquel realizado con la declaración de Paisaje Pintoresco, pero no era evidente, habida cuenta de la tendencia de aquel entonces de calificar amplios espacios abiertos como parques e incorporarlos como sistemas generales, sin liberarlos de la tensión urbanizadora. Por tanto, el Plan Especial contaba con una ventaja que hacía más fácil proteger e impulsar la conservación del complejo de espacios abiertos del valle, muy vinculados a sus edificios y lugares históricos (De las Rivas, Tremiño y Vázquez, 1998).

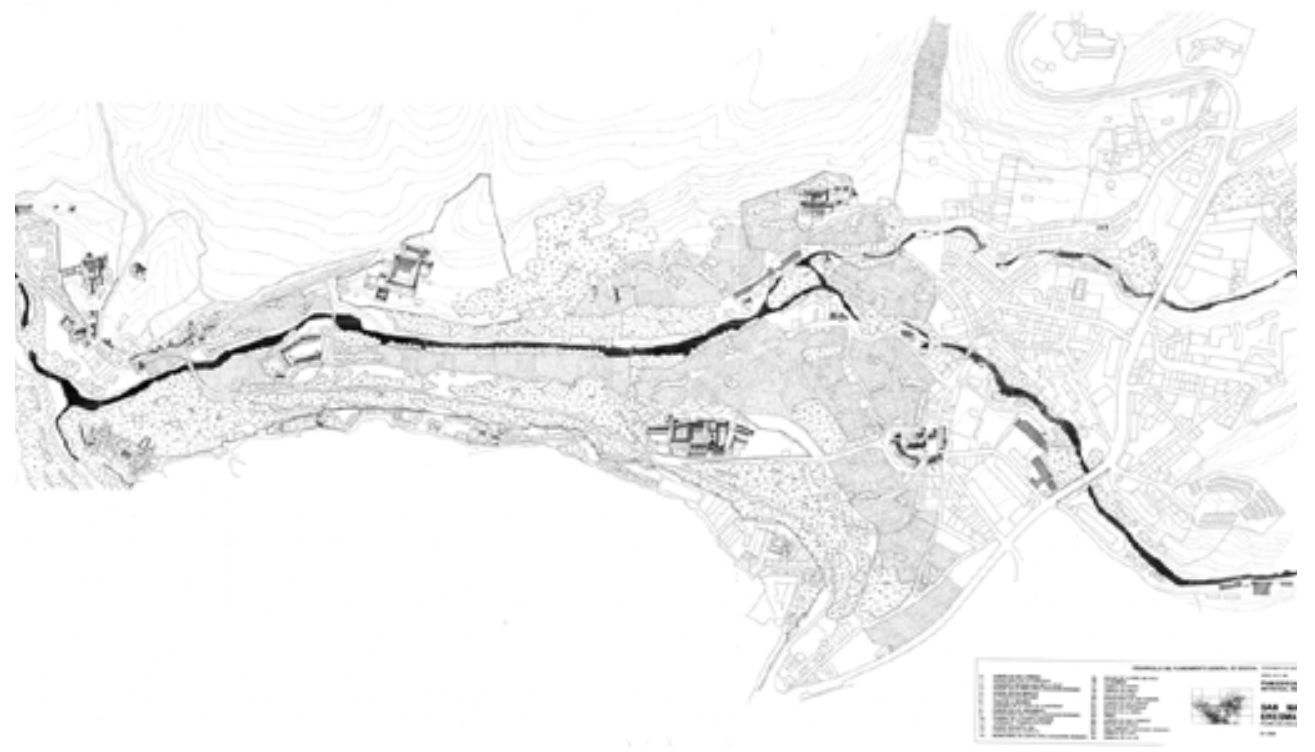

Figura 3a. Plan Especial del río Eresma a su paso por Segovia. Bienes y paisajes protegidos 
Más adelante, tuvimos una nueva oportunidad para contribuir a la conservación del tramo urbano del valle del Eresma desde una escala y desde un instrumento diferente: las Directrices de Ordenación Territorial de Segovia y Entorno (DOTSE) ${ }^{5}$. Para garantizar la conservación de un conjunto complejo como es la vega del Eresma a su paso por Segovia, entre las laderas de la muralla y un desarticulado conjunto de espacios construidos y vacíos de alto valor histórico y paisajístico, es necesario combinar instrumentos y fortalecer la lógica de protección y puesta en valor con acciones coordinadas que destaquen la condición de conjunto, mejor dicho, de sistema. Y es el río el que hace todo ello posible. El valle del Eresma necesita un plan especial de protección específico, dado que pertenece a la sustancia de la ciudad histórica. Sin embargo, desde la escala de la ciudad-región, las Directrices pueden colaborar articulando la comprensión y/o protección del valle en un contexto más amplio. Las DOTSE incorporaron una estructura de protección que procuraba combinar una lectura ecológica con la perspectiva cultural, muy arraigada en Segovia. Inventariar y proteger los espacios más valiosos es solo el primer paso y las DOTSE incorporaron dos herramientas que completaban esta tarea. Por un lado, mediante el recurso a unidades del paisaje, se introducían unos criterios de gestión homogéneos en el municipio de Segovia y en los de su entorno. A la vez, se detectaron procesos naturales activos. Se hizo énfasis en aquellos de mayor riesgo (inundaciones, deslizamientos, suelos expansivos...), pero también en otros, como es el caso de la erosión en arroyos y laderas, que podrían inducir acciones directas de mejora del paisaje. En definitiva, con la declaración de paisaje pintoresco y las DOTSE se dota a Segovia de herramientas para garantizar la salvaguardia de uno de sus sistemas paisajísticos más valiosos: el Eresma y su entorno.

Insisto en que la estabilidad de determinados paisajes históricos no es casual, sino que es resultado de una valoración continuada a lo largo del tiempo que libera a dichos espacios de la tensión urbanizadora. Sin duda influye en ello la inercia de las grandes propiedades institucionales, que en el valle del Eresma

5 Las Directrices de Ordenación Territorial de Segovia y Entorno (aprobadas en 2005) son seleccionadas para la exposición de la Biennal of Towns \& Town Planners in Europe, organizada por la Asociación Europea de Urbanistas, en Barcelona, en abril de 2003 (De las Rivas Sanz, Juan Luis y equipo (2016): Directrices de ordenación de ámbito subregional de Segovia y entorno, Valladolid, Junta de Castilla y León, Consejería de Fomento). 
son muy relevantes, pero también la cultura local, más ejemplar en algunos lugares que en otros muy próximos. El barrio de San Lorenzo sufre una tensión especulativa generada desde la vía Roma, perpendicular al Eresma y uno de los principales accesos de la ciudad. Allí ha sido imprescindible contar con un sistema de protección más o menos concreto, desde el plan Mesones a los planes especiales. Sin embargo, en el barrio de San Marcos, aguas abajo, la calidad de la conservación es tanto resultado de cierta atonía, propia de un pequeño barrio periférico, como de la proximidad y presencia de monumentos muy relevantes, combinados con una inercia de prados, huertas, jardines, romerales... impulsados por una ciudadanía que valora la naturaleza del enclave, sin llegar a privatizar todas sus potencialidades.

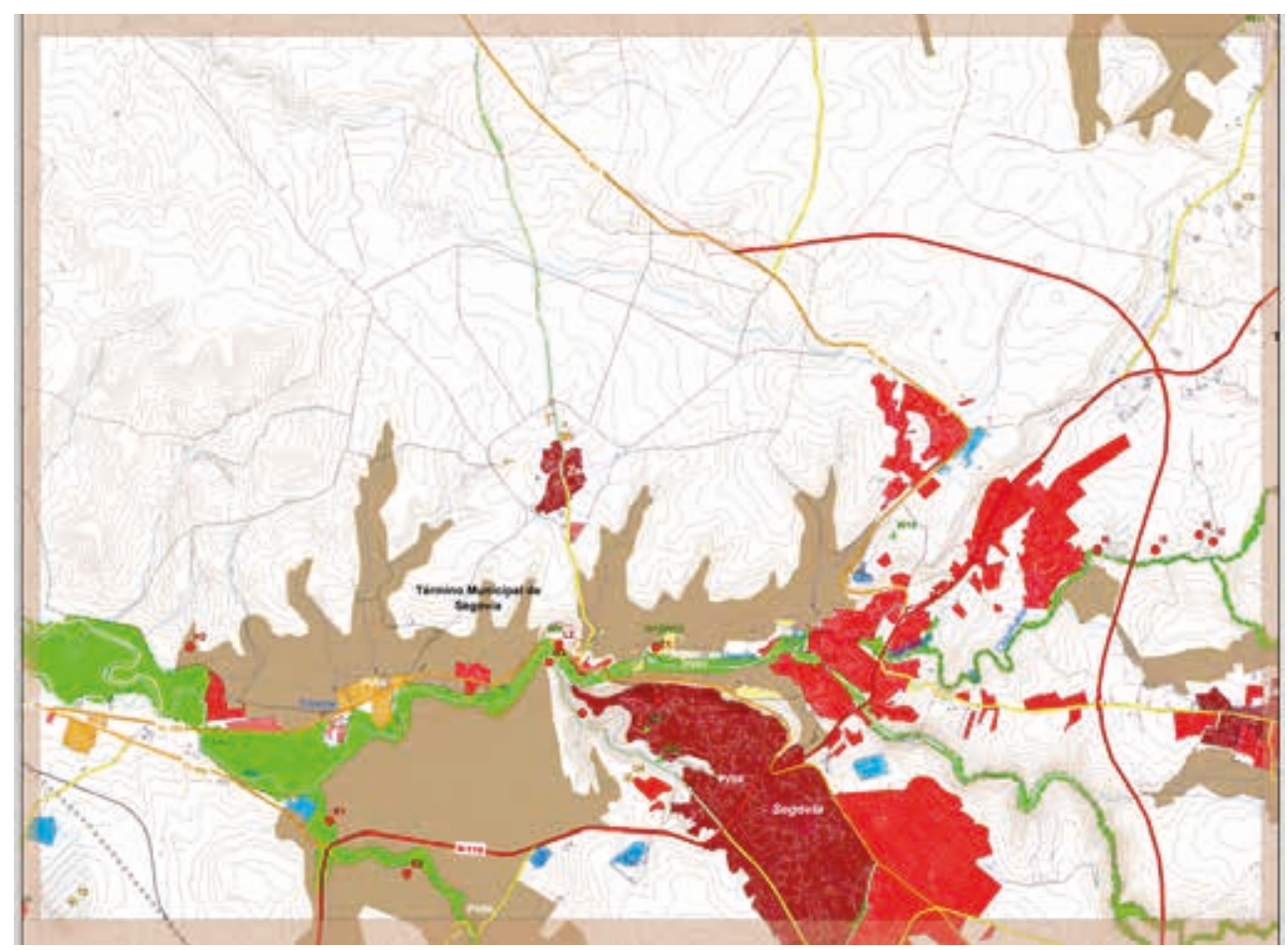

Figura 3b. El Eresma a su paso por Segovia en las DOTSE. Plano de espacios protegidos 


\section{VOLVIENDO A LA SECCIÓN DEL VALLE: CIUDAD-CAMPO, LA CIUDAD EN SU REGIÓN, LA CIUDAD SIN SU TERRITORIO}

Anne Whiston Spirn, avanzando desde su crítica a unas ciudades convertidas en jardines de granito (1984), pone juntas dos de las imágenes más relevantes de la cultura de la planificación urbana y regional en relación con los ríos: las secciones del valle de Patrick Geddes y de Ian McHarg, dos pioneros de la planificación ecológica (Whiston Spirn, 2000) (figuras 4a y 4b). La necesidad de comprender antes de planificar, antes de evaluar cualquier alternativa urbanística, se materializa en la idea de que un área urbana no puede ser interpretada sin su entorno regional y que, en dicha interpretación, es clave el sistema fluvial en que cada ciudad se asienta. McHarg distinguía con claridad en Proyectar con la naturaleza que ello no daba todavía forma a un plan, pero era lo que había que hacer antes de trazar un plan. El esfuerzo de integrar conocimientos de Geddes o el impulso que da McHarg a la evaluación de alternativas, con su metodología de análisis de idoneidad, daban cuenta de intentos concretos por establecer un vínculo entre el análisis y el plan, entre conocimiento y acción.

La relevancia para la planificación de los ríos y en general de todas las estructuras del agua, cursos, riberas, lagunas, etc. es evidente y, sin embargo, necesita seguir siendo reivindicada. Lo he tratado de mostrar con algunos ejemplos de planificación urbana que encuentran su fundamento en el reconocimiento de la forma del territorio, pero nuestro territorio, nuestro paisaje es y va a ser siempre un paisaje histórico, un paisaje cultural, en el que los ríos no solo son condicionantes de su fisiografía, sino oportunidades y recursos tanto naturales como patrimoniales. Los paisajes fluviales son sistemas de sistemas, son espacios funcionales con un régimen de regulación preciso que, administrados por las autoridades de cuenca, trascienden el objeto específico que las propias autoridades gobiernan. Pertenecen a la sustancia del territorio, le dan forma, permiten explicar los usos históricos y sus vestigios, y guardan en sus orillas y entornos una extraordinaria variedad de situaciones patrimoniales, desde una simple pesquera a las ruinas de un molino. Además, son el armazón potencial, la estructura de un sistema territorial más sostenible. Ahora que el nuevo paradigma urbano, la nueva agenda, está determinada por principios de habitabilidad, equidad y salud como evolución concreta de las ideas generales que la propia lógica de la sostenibilidad ha 
impuesto, los ríos son, si cabe, más prioritarios, y ello exige un esfuerzo cultural. La planificación espacial no puede trabajar sola, necesita ser urgida por la sociedad, necesita la exigencia de una sociedad capaz de reconocer la calidad.
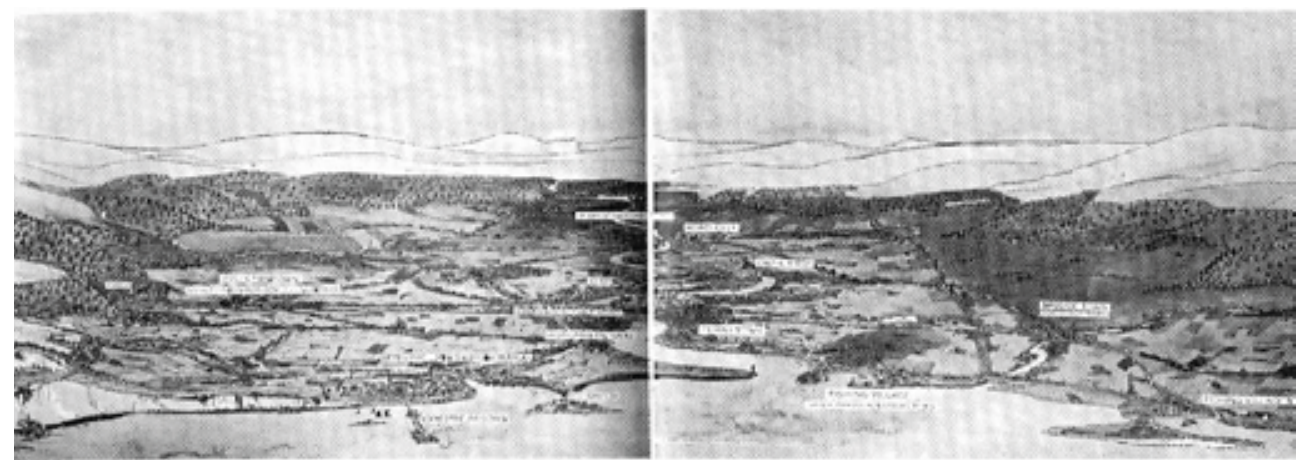

Figura 4a. La sección del valle, Patrick Geddes, 1911. Recogido por Anne Whiston Spirn

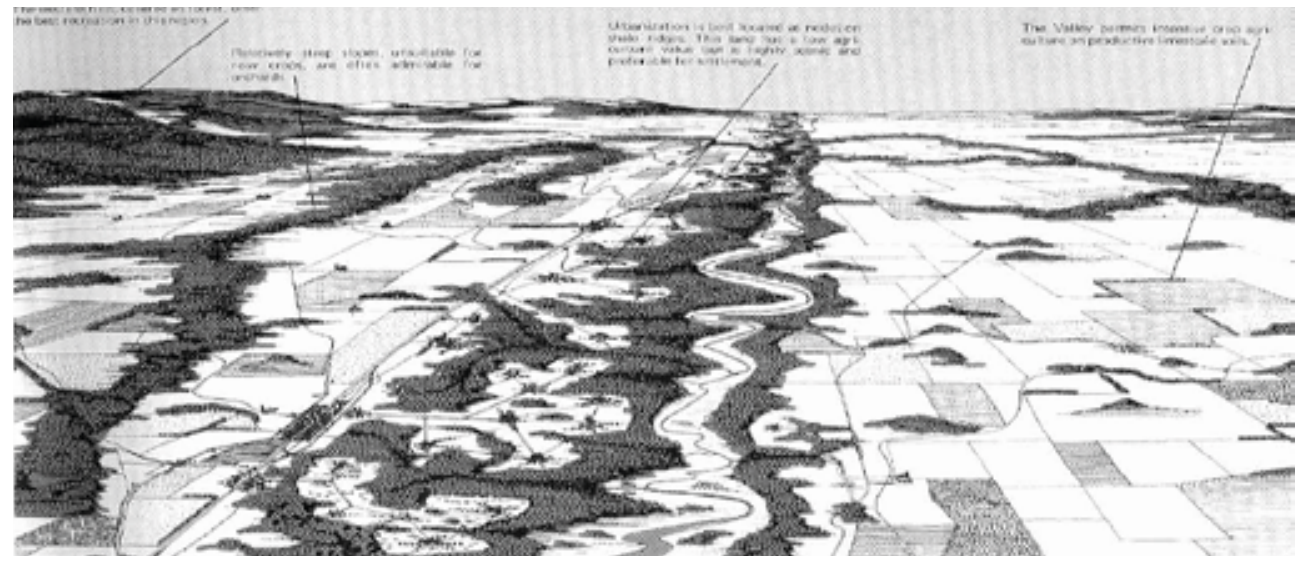

Figura 4b. Región fisiográfica del gran valle del Potomac, Ian McHarg, 1965-66. Recogido por Anne Whiston Spirn

Hoy, los ríos urbanos se incorporan a la perspectiva de la infraestructura verde, de los servicios de los ecosistemas, de la reconsideración global de los espacios periurbanos, incluida una agricultura diferente. Comenzamos a hablar de soluciones basadas en la naturaleza y de la gestión del metabolismo urbano, tanto físico como social. Sin embargo, para que todo ello sea efectivo más allá del len- 
guaje y de las tendencias de la técnica, para que influya de verdad en la práctica cotidiana, es imprescindible un cambio cultural, un cambio de las mentalidades y expectativas que dirigen lo urbano. La geografía y la historia han de estar en la raíz de este cambio. Parafraseando a Geddes, para planificar comprender... Cada río tiene su propia forma, cada ribera nos propone un paisaje construido lentamente, un ecosistema preciso, a veces maltratado. Es necesario acercarse a cada caso y aprender, desde un conocimiento consciente de que no existen soluciones universales. 


\section{REFERENCIAS BIBLIOGRÁFICAS}

CHOAY, Françoise (1994): «Le règne de l'urbain et la mort de la ville», en La Ville. Art et Architecture en Europe 1870-1993 (catálogo), París, Centre Georges Pompidou.

Forman, Richard T. T. (2014): Urban Ecology: Science of Cities, Boston, Cambridge University Press.

Hough, Michael (1998): Naturaleza y ciudad: planificación urbana y procesos ecológicos, Barcelona, Gustavo Gili.

RIVAS, Juan Luis de las (1996), "La naturaleza en la ciudad-región: paisaje, artificio y lugar», en Javier Maderuelo (ed.), El paisaje. arte y naturaleza, Huesca, Diputación Provincial.

RIVAS, Juan Luis de las (2001): «En los paisajes de la ciudad-región», OP, ingeniería y territorio, 54, 74-83.

RIVAS, Juan Luis de las (2006): «El paisaje como regla: el perfil ecológico de la planificación espacial», en M.a Castrillo / J. González-Aragón (coords.), Planificación territorial y urbana, Valladolid / México, Universidad de Valladolid / Universidad Autónoma Metropolitana, 11-36.

RIVAS, Juan Luis de las (2009): «Ciudad sobre ciudad. Interferencias entre pasado y presente en Europa», en Ciudad sobre ciudad, Valladolid, Fundación del Patrimonio Histórico de Castilla y León.

RIVAS, Juan Luis de las (2010): «La ordenación de los procesos metropolitanos. Las Directrices de Ordenación del Territorio de Valladolid y Entorno», en L. Galiana / J. Vinuesa (coords.), Teoría y práctica para una ordenación racional del territorio, Madrid, Editorial Síntesis, 301-319.

RIVAS, Juan Luis de las (2012): «Vittoria Calzolari, docente, urbanista e paesaggista impegnata», en Alfonso Álvarez Mora (ed.), Paesistica. Paisaje Vittoria Calzolari, Valladolid, IUU, Universidad de Valladolid, 35-52.

RIVAS, Juan Luis de las (2013): «Hacia la ciudad paisaje. Regeneración de la forma urbana desde la naturaleza», Urban NS, 5, 79-93.

Rivas, Juan Luis de las / Cristina Tremiño / Gregorio Vázquez (1998): «Paisaje, historia y ciudad. La conservación del valle del Eresma a su paso por la ciudad de Segovia», Ciudades, 4, 251-269.

RIVAS, Juan Luis de las / Ignacio SAN MARTín / Frederick STEINER (2000): «Introducción a la edición española», en Ian McHarg, Proyectar con la naturaleza, Barcelona, Gustavo Gili.

Whiston Spirn, Anne (1984): The Granite Garden, Urban Nature and Human Design, Nueva York, Basic Books.

Whiston Spirn, Anne (2000): «Ian McHarg, Landscape Architecture, and Environmentalism: Ideas and Methods in Context», en Michel Conan (ed.), Environmentalism in Landscape Architecture, Washington, Dumbarton Oaks Research Library and Collection. 

ESTRATEGIAS, DE RECUPERACIÓN DEL PATRIMONIO INDUSTRIAL DEL RIO TYNE EN EL ÁREA METROPOLITANA DE NEWCASTLE (REINO UNIDO). APROXIMACIONES CONJUNTAS AL PATRIMONIO CULTURAL Y NATURAL

Rosa Teira

Arquitecta

Inspectora de edificios e áreas históricas

da rexión NE. Historic England

DOI: $10.17075 /$ pvpcr.2021.004 



\section{EL ÁREA DE ESTUDIO: TYNESIDE Y SU REGIÓN}

El río Tyne es uno de los ríos más importantes de la región nordeste de Inglaterra. Esta región, que cuenta con algo más de dos millones y medio de habitantes, está formada por los condados de Northumberland y Durham, y las áreas metropolitanas de Cleveland, en torno al río Tees, y Tyne and Wear, en torno a los ríos homónimos (figura 1). Esta última supera ligeramente el millón de habitantes y se constituye como una gran conurbación que incluye cuatro autoridades locales $^{1}$ a lo largo de los $20 \mathrm{~km}$ que forman el tramo final del río Tyne.

El motor de desarrollo histórico de la región ha girado tradicionalmente en torno a la explotación de sus abundantes reservas de carbón. Esta acti-

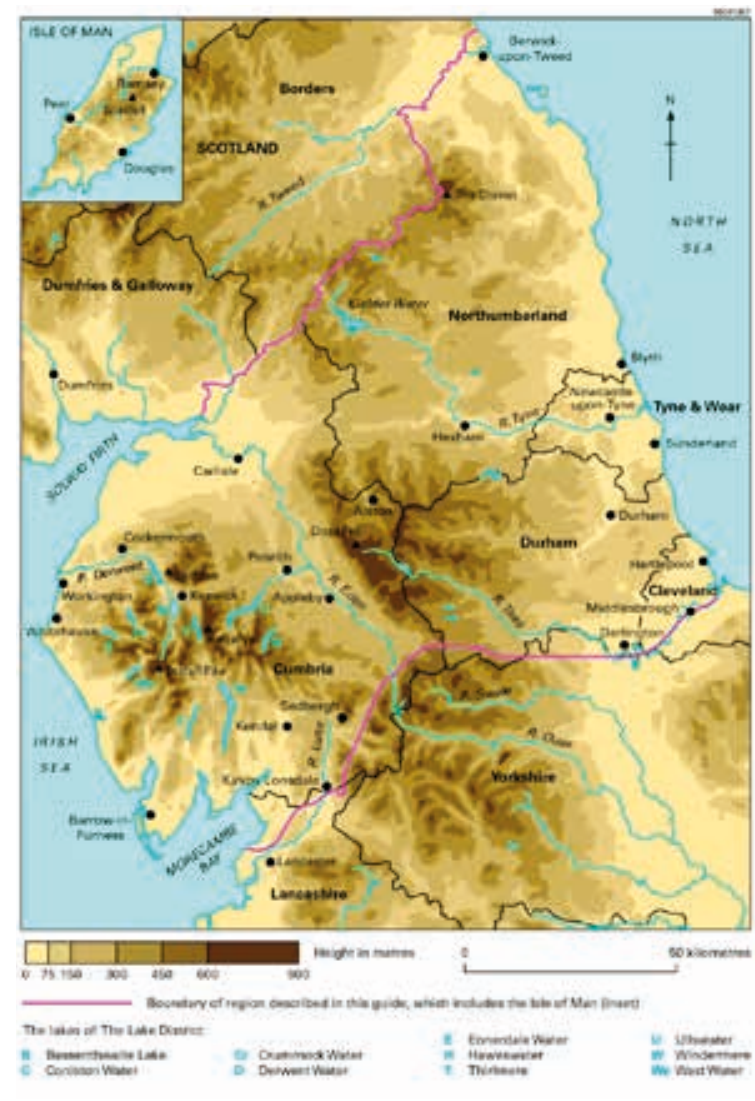

Figura 1. El río Tyne y los límites de los condados de Northumberland, Durham y las áreas metropolitanas de Tyne $\&$ Wear y Cleveland vidad, que en el siglo XVII ya tenía relevancia a escala nacional $^{2}$, experimentará una profunda expansión a lo largo de los siglos posteriores y se mantendrá hasta las primeras décadas del siglo $\mathrm{xx}$, dejando un profundo

1 Estas son Newcastle (capital de la región), Gateshead, North Tyneside y South Tyneside.

2 Londres es el principal destino del carbón que se extrae en la región y comercializa a través de Newcastle, pero la ciudad también posee importantes relaciones comerciales con los Países Bajos y los países bálticos. 
impacto en el conjunto de su territorio. La incipiente red de raíles de madera y tracción animal creada para conectar los pozos con las zonas de descarga a lo largo del río se transformará en los siglos posteriores en una densa red de ferrocarril ampliada para incorporar el transporte de pasajeros (figura 2). En paralelo al desarrollo de la industria del carbón, se desarrollan otras industrias, como la de producción de vidrio, metalurgia o cerámica. En el siglo XIX, la introducción de la máquina de vapor y el desarrollo de tecnología capaz de dragar el río posibilitaron el acceso de barcos de mayor calado río arriba, ampliando la intensidad de la actividad industrial de manera exponencial.

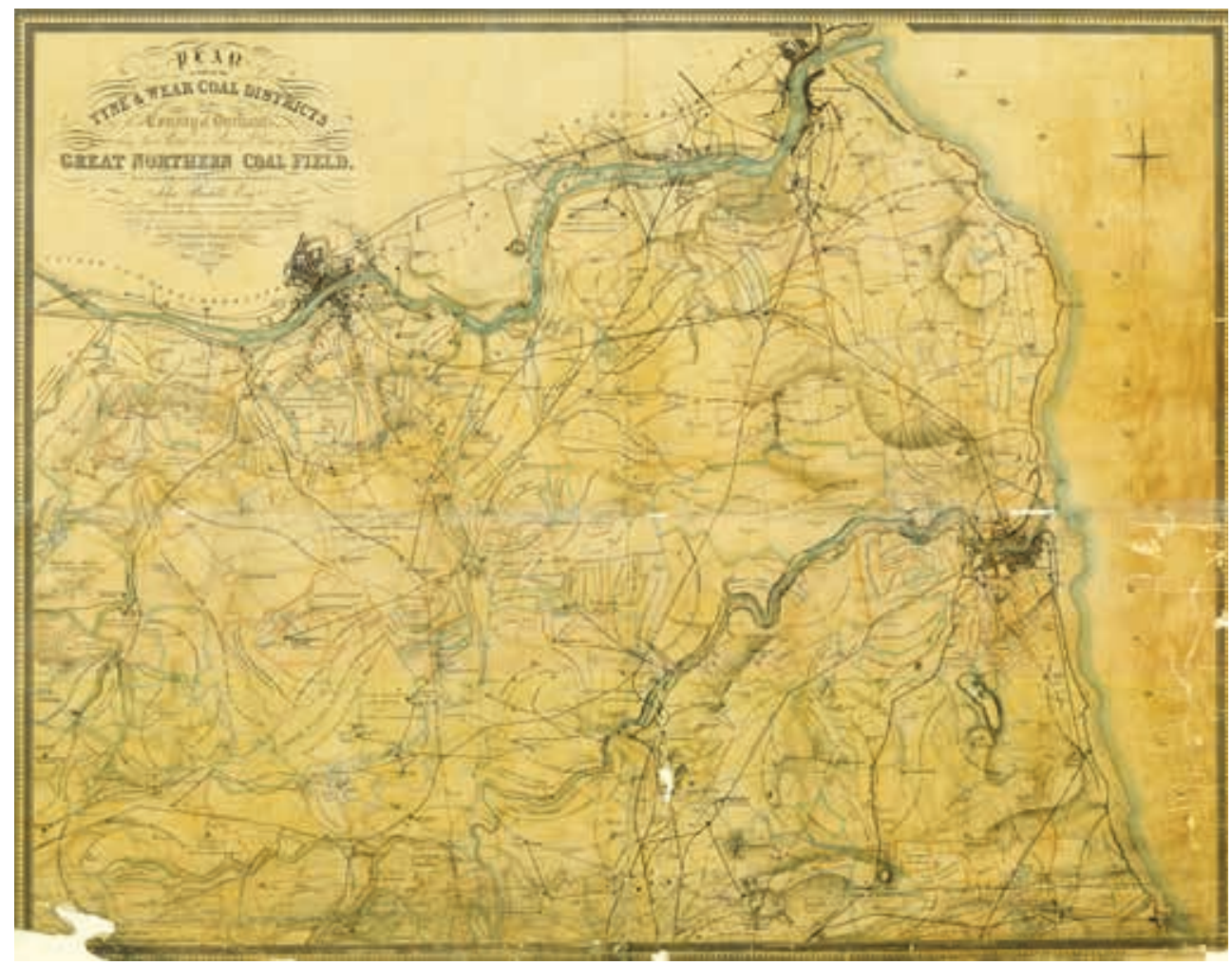

Figura 2. Plano de 1843 que muestra la red de ferrocarril que conecta pozos con muelles de descarga en los ríos Tyne y Wear

El río Tyne (y, de manera semejante, el Wear y el Tees) se convierte en un auténtico canal de infraestructura, de importancia estratégica nacional por la 
industria que acoge y que incluye transporte de carbón ${ }^{3}$, astilleros, ingeniería hidráulica o armamento, por citar los más importantes (figuras 3, 4).

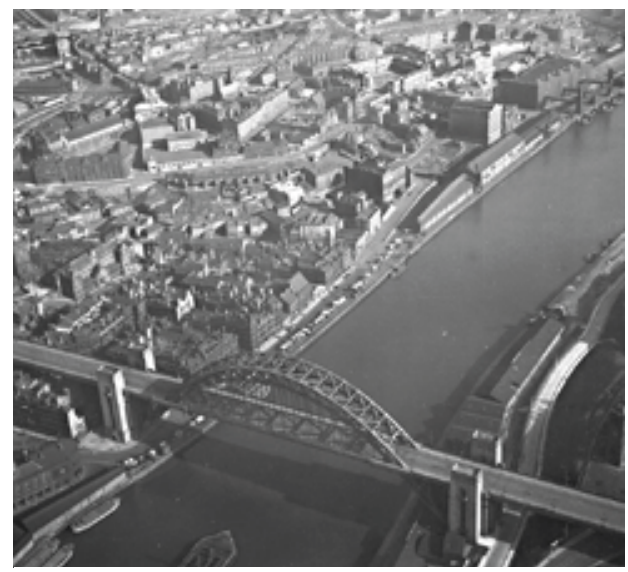

Figura 3. Vista aérea de Newcastle y el puente Tyne en 1950. Aerial view of the Quayside, Newcastle upon Tyne, March 1950 (TWAM ref. DT.TUR/2/4402), Tyne \& Wear Archives \& Museum

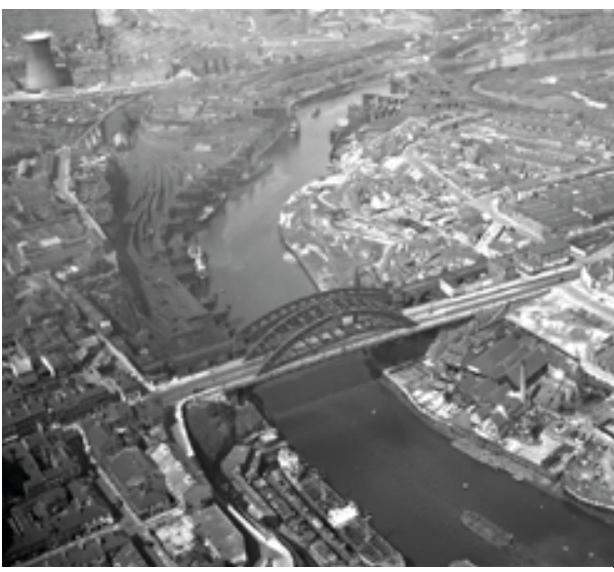

Figura 4. Vista aérea de Sunderland, río Wear, 1949. Aerial view of Wearmouth Bridge, Sunderland and surrounding area, May 1949 (TWAM ref. DT.TUR/2/2927F), Tyne \& Wear Archives \& Museums

El problema de la contaminación está ligado a la industrialización y artificialización del borde fluvial. A la contaminación que deriva de la industria hay que añadir los vertidos de la ciudad (que en 1855 dispone de más de 270 colectores que descargan directamente al Tyne), que empeoran con la conexión de los servicios domésticos a la red general de saneamiento 4 . Uno de los impactos más visibles es la extinción de especies otrora abundantes, como el salmón, lo que propiciará la creación de las primeras instituciones de protección (el Tyne Salmon Conservancy se constituye en 1866), precursoras de los River Trust contemporáneos.

Esta intensa actividad industrial entra en declive después de la Primera Guerra Mundial debido al aumento de la competición a escala global y provoca el cierre

3 Hasta 1960, el carbón era la principal fuente de energía del país.

4 La historia medioambiental del río Tyne y la relación que las distintas sociedades tenían con él es abordada por la historiadora Leona Skelton (Skelton, 2017). 
de numerosas minas y astilleros en las décadas de 1950 y 1960. Dicha tendencia, acelerada por las políticas de mercado libre y desmantelamiento industrial de finales de 1970, convertirá a esta región urbana en una de las más deprimidas del país, al perder su mayor motor de desarrollo económico y verse enfrentada a la cara menos amable del proceso industrializador: los altos niveles de contaminación y desconexión del río del entorno de la ciudad.

La construcción del colector interceptor del río Tyne y la renaturalización del borde fluvial iniciados en la década de 1970 serán acciones fundamentales en la reversión del proceso de deterioro urbano y mejora del borde fluvial que favorecerán las primeras estrategias de regeneración urbana iniciadas a finales de la década de 1980.

Estas estrategias de regeneración urbana ${ }^{5}$ se apoyan en la inserción de dotaciones culturales e institucionales, además de en la mejora de la accesibilidad al río y la revalorización de elementos patrimoniales clave. En 1990, la elección de Gateshead como enclave de uno de los National Garden Festivals ${ }^{6}$ hará posible la descontaminación de amplias zonas industriales que se transformarán posteriormente en tejido residencial. En los muelles del este de Newcastle (el llamado East Quayside), la inserción del edificio de juzgados y el acceso público al muelle servirán como ejes de desarrollo de toda el área. En la década posterior, estas iniciativas se extenderán a la orilla opuesta. La conversión del antiguo depósito de harina ('Baltic Mills') en museo de arte contemporáneo junto con la inserción de nuevas piezas culturales como el auditorio SAGE, proyectado por el arquitecto Norman Foster, y la mejora de la conexión entre ambas márgenes del río con la construcción del puente del Milenio ${ }^{7}$ acondicionarán importantes áreas de la ciudad para el uso y disfrute del público (figura 5).

5 El paisaje urbano del río Tyne, su evolución histórica, los cambios en las instituciones de gobierno y planeamiento y la gestión del proceso de cambio han sido estudiados por Loes Veldpaus, Philippa Carter y John Pendelbury, de la Universidad de Newcastle, en el marco de un proyecto europeo de investigación.

6 Los National Garden Festivals fueron una iniciativa de regeneración cultural de áreas abandonadas en zonas industriales del país que tuvo lugar durante las décadas de 1980 y 1090 de la mano del gobierno conservador. De frecuencia bianual, se inspiraban en los Bundesgartenschau alemanes. Se celebraron cinco en total: Liverpool, en 1984; Stoke on Trent, en 1986; Glasgow, en 1988; Gateshead, en 1990, y Ebbw Vale, en 1992, con distintos resultados.

7 Esta pasarela peatonal se inspira en el espíritu de innovación tecnológica de los puentes históricos que conectan Newcastle y Gateshead: el puente Tyne, el puente High Level o el puente Swing. 


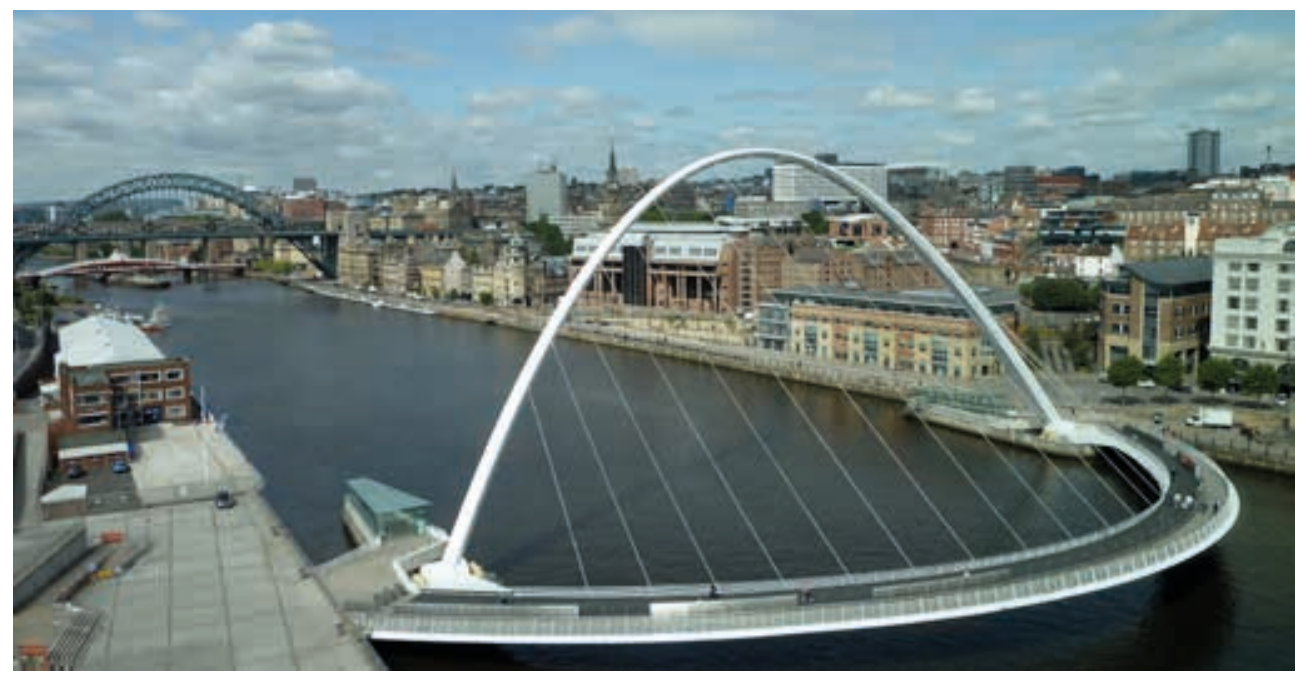

Figura 5. El puente del Milenio visto junto a los otros puentes históricos de Newcastle

\section{EL PATRIMONIO CULTURAL EN LA GESTIÓN DE LOS ESPACIOS NATURALES Y DEL TERRITORIO}

La protección del patrimonio cultural forma parte de la protección, puesta en valor y gestión de los espacios protegidos de orden natural y del territorio en general. En la región, esto se aprecia en los planes de gestión de sus espacios naturales protegidos; en lo relativo al paisaje y al territorio, en la visión establecida en las denominadas National Character Areas, y desde el punto de vista metropolitano, a través de los estudios de infraestructura verde.

\section{Espacios naturales protegidos}

La región cuenta con un gran número de espacios naturales protegidos de distinto orden. A escala nacional, dispone de varios parques nacionales y áreas de belleza natural destacada $\left(\mathrm{AONB}\right.$, por sus siglas en inglés) ${ }^{8}$. Estas últimas incluyen tres áreas de costa patrimonial, así como áreas de especial protección (a escala europea) con lugares RAMSAR y SSSI (figura 6).

8 AONB o Areas of Outstanding Natural Beauty. Parques nacionales: Northumberland NP, Yorkshire Dales NP y North Yorkshire Moors NP. AONB: Northumberland Coast y North Pennines AONB. 


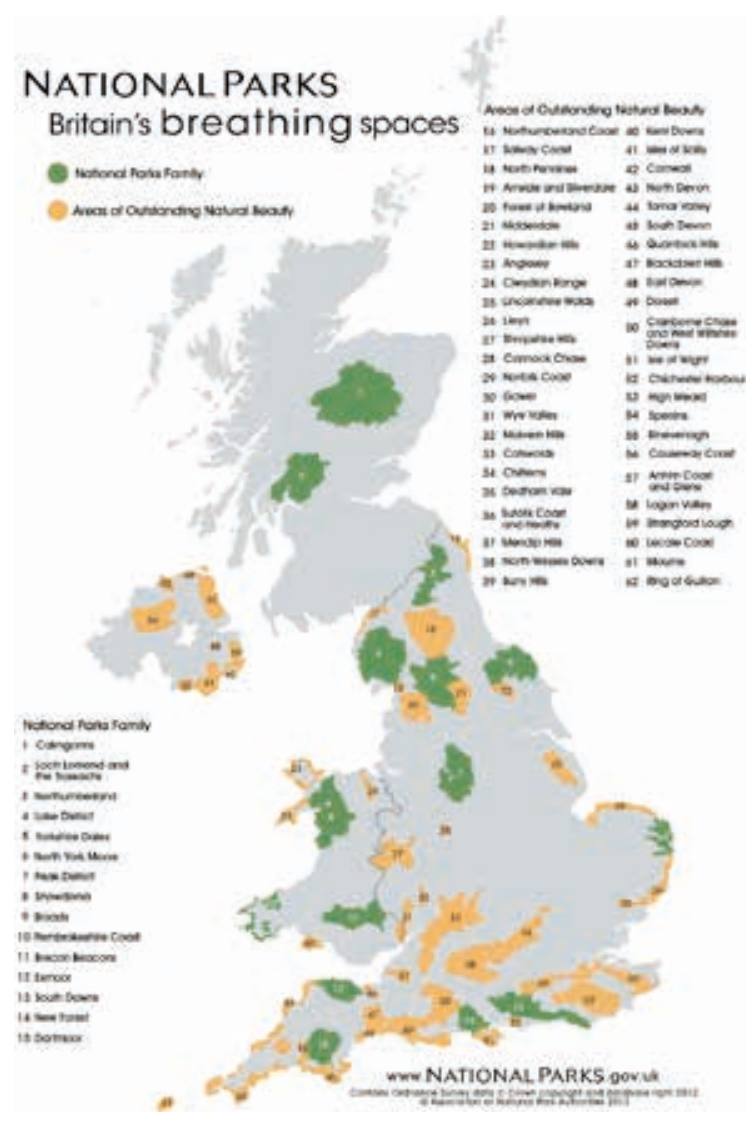

Figura 6. Parques nacionales y áreas naturales de belleza destacada
Los principales objetivos de los planes de protección y gestión de estos parques nacionales y AONB son: "conservar y realzar su belleza natural, fauna y patrimonio cultural, y promover oportunidades para su apreciación y disfrute por parte del público» ${ }^{9}$. Promocionar su accesibilidad es, por tanto, un objetivo fundamental $y$, en ese sentido, el patrimonio cultural desempeña un papel clave, no solo como elemento configurador del paisaje existente, sino también desde el punto de vista de su potencial como elemento de atracción de visitantes ${ }^{10}$. La recuperación patrimonial se impulsa no solo a través de programas específicos de actuación, sino por medio de ayudas más genéricas con los Countryside Stewardship Schemes ${ }^{11}$.

9 DEFRA (2016): National Parks: 8-point plan for England (2016 to 2020).

10 Un ejemplo de esta actitud se aprecia en la web del AONB de los North Pennines. Sus programas de acción cubren tanto intervenciones en elementos naturales como patrimoniales.

11 Los Countryside Stewardship Schemes o programas de custodia del territorio están dirigidos a agricultores y propietarios de espacios forestales y buscan la puesta en práctica de mejoras medioambientales que incluyen también el mantenimiento de elementos patrimoniales y la mejora de su accesibilidad, tanto física como virtual, a través de la interpretación. Para más información, véase este enlace: www.gov.uk/ government/publications/historic-buildings-restoration-grant-countryside-stewardship. 


\section{National Character Areas}

A escala nacional, es importante mencionar las denominadas National Character Areas $^{12}$, que organizan el territorio en una serie de áreas atendiendo a criterios paisajísticos. Su objetivo es «servir de referencia para el establecimiento de iniciativas de conservación desde un punto de vista paisajístico, promover convenios entre distintas entidades e informar de decisiones sobre la capacidad de cambio y gestión del territorio» ${ }^{13}$. Se basan en el Libro Blanco del Medio Ambiente, Biodiversity 2020 y la Convención Europea del Paisaje.

Son documentos muy sintéticos que, apoyándose en estudios sectoriales más detallados, establecen las características distintivas de cada área, la evolución y tendencias de su paisaje, y las oportunidades y servicios que pueden ofrecer desde el punto de vista medioambiental, así como la dimensión de sus beneficiarios (local, regional, nacional o internacional). Este análisis lleva a la formulación de unas Declaraciones de Oportunidad Medioambiental, específicas para cada área. En cuanto a las oportunidades y servicios medioambientales, se considera el grado de relevancia de cada área como proveedora de servicios (alimentos, agua), reguladora de servicios (clima, erosión, calidad del suelo, calidad y flujo del agua, inundación y erosión costera) y provisión de servicios culturales (esencia del lugar, sentido histórico ${ }^{14}$, ocio, biodiversidad y geodiversidad), y se incluyen las relaciones e interdependencias con otras unidades de paisaje (figura 7).

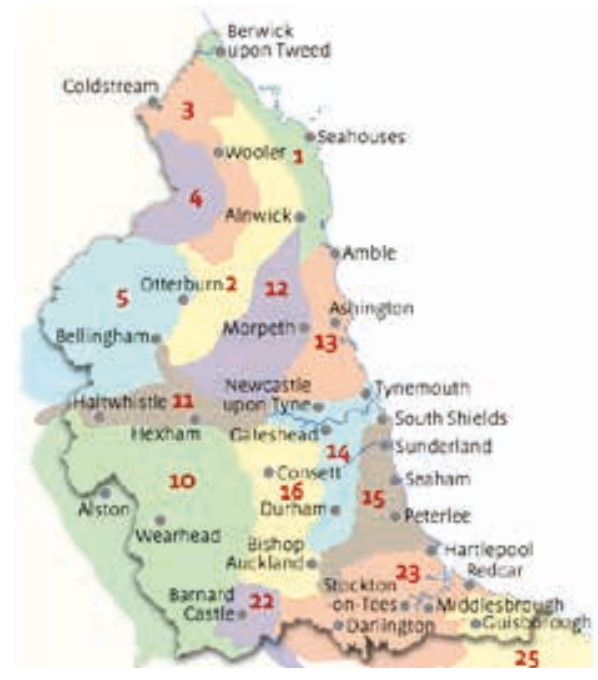

Figura 7. National Character Areas en la región nordeste de Inglaterra

${ }^{12}$ Equivalente a nuestras unidades de paisaje. Su creación se remonta a la década de 1980. En 2012, se finaliza su tercera revisión, donde se reconocen un total de 159 áreas y se introduce por primera vez una visión de ecosistemas y provisión de servicios medioambientales.

13 Natural England (2019): National Character Areas.

14 Por ejemplo, nuestra área de estudio está incluida dentro de las «Tierras bajas del Tyne y el Wear». La esencia del lugar se corresponde con el legado de la minería y su influencia en el paisaje, mientras que el 
En definitiva, son documentos de carácter estratégico que trascienden los límites administrativos de las autoridades locales y deberían permitir el establecimiento de estrategias conjuntas en las que el patrimonio sea un elemento fundamental del paisaje.

\section{Green belt}

A escala de área metropolitana, la región del Tyne and Wear dispone de un cinturón verde o green belt (figura 8). Su designación se remonta a la década de 1960. Creados con el propósito de prevenir el urban sprawl o crecimiento suburbano, los green belts se localizaron fundamentalmente en torno a las grandes conurbaciones del país ${ }^{15}$.

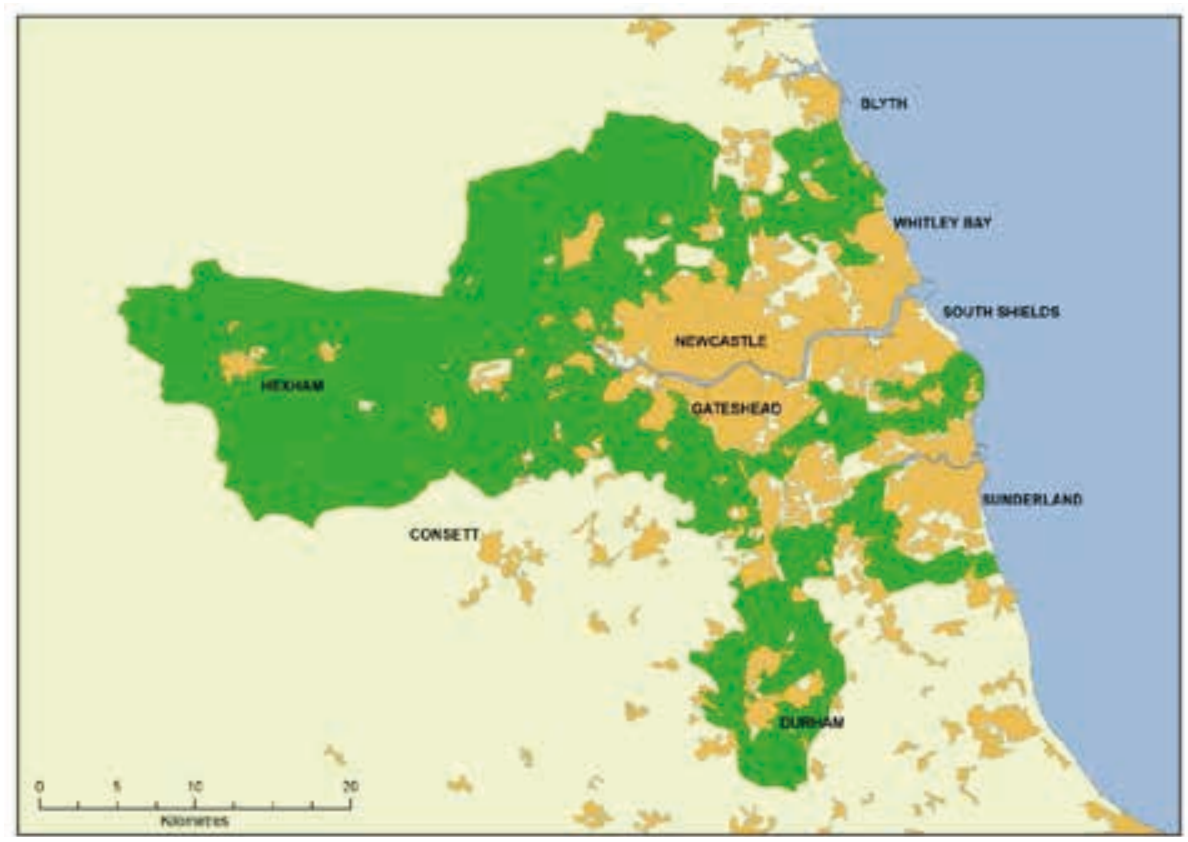

Figura 8. Tyne y Wear Green Belt

sentido histórico tiene que ver con las influencias que los distintos períodos históricos han dejado en el área: el muro de Adriano, el castillo y la catedral de Durham (Patrimonio de la Humanidad), etc.

15 Actualmente existen 14 green belts a escala nacional que cubren un 12,4\% del territorio. 
Las directrices de planeamiento a escala nacional ${ }^{16}$ establecen como prioridades la protección de los green belts; la lucha contra el cambio climático, las inundaciones y la erosión costera; la conservación y protección del medio ambiente, y la conservación y protección del entorno histórico ${ }^{17}$. Así mismo, establecen que su característica principal es su carácter abierto y sus funciones principales son las siguientes: «1) controlar el crecimiento de los suburbios, 2) prevenir la fusión de ciudades vecinas, 3) proteger el "rural" de una urbanización inapropiada, 4) preservar el entorno y el carácter de las ciudades históricas, y 5) ayudar a la regeneración urbana a través de la promoción del reciclaje de zonas abandonadas» ${ }^{18}$.

Una vez designados, corresponde a las autoridades locales tratar de mejorar el uso de los green belts incrementando su accesibilidad, proporcionando oportunidades para el ocio y las actividades deportivas al aire libre con la retención y mejora de paisajes, y la biodiversidad, además de la mejora de zonas dañadas y abandonadas.

A escala local, esto se materializa a través de los estudios de infraestructura verde. En el caso del río Tyne, su importancia como corredor estratégico, espacio de ocio y corredor de fauna se refleja en la elaboración de un informe específico para el río ${ }^{19}$ destinado a entender su potencial, debilidades, fortalezas, oportunidades y amenazas. El informe reconoce la importancia histórica del río, razón de la existencia de los asentamientos de Newcastle y Gateshead; la artificialización del río a raíz del desarrollo industrial, y la necesidad de continuar renaturalizando el área. Así mismo, reconoce la importancia y potencial de las antiguas vías de transporte de carbón como corredores verdes y hábitats importantes para la fauna salvaje y la necesidad de mejorar la accesibilidad y compatibilidad/convivencia de los usos humano y animal.

Se considera también la contribución económica que el río aporta a la ciudad, ya que «posibilita la creación de espacios de gran calidad que garantizan que los espacios urbanos puedan competir en un ámbito global» ${ }^{20}$. Desde el punto de vista paisajístico, establece la compatibilidad entre paisaje natural, paisaje urbano

\footnotetext{
${ }^{16}$ Los llamados National Planning Policy Framework (NPPF), su última revisión es de julio 2018.

${ }_{17}$ NPPF (2018), section 3, Plan-making, strategic policies (p. 9).

18 NPPF (2018), section 13 (p. 40).

${ }^{19}$ El informe es elaborado de manera conjunta entre las autoridades de Newcastle y Gateshead. Lamentablemente, no incluye a las autoridades vecinas río abajo (North y South Tyneside).

${ }^{20}$ Newcastle CC / Gateshead CC (2011): Green Infrastructure Study-River Tyne Report, p. 61.
} 
y patrimonio cultural en cuanto que la infraestructura verde "puede ayudar a realzar el paisaje natural y urbano y los elementos culturales del río, al tiempo que los elementos patrimoniales pueden servir de incentivo para los usuarios de la infraestructura verde» ${ }^{21}$.

\section{INTERVENCIONES CONJUNTAS EN EL PATRIMONIO NATURAL Y CULTURAL}

Los siguientes ejemplos presentan una aproximación conjunta a la protección del patrimonio cultural y natural. De distinta escala y énfasis, los dos primeros se centran en la recuperación de elementos del patrimonio industrial y el último consiste en la recuperación paisajística de una residencia y parque asociado. Las dos primeras propuestas han sido posibles gracias a la financiación del National Lottery Heritage Fund ${ }^{22}$ (NLHF) y poseen un fuerte componente social; la última representa un ejemplo de iniciativa privada.

\section{Muelles de descarga de Dunston (Dunston Staithes)}

Considerada la estructura de madera de mayores dimensiones de este tipo en Europa, con 526 metros de longitud, es la única que permanece en pie de entre las más de una treintena que existían en el río Tyne. La estructura fue construida en 1893 por la Compañía de Ferrocarriles del Nordeste para cargar carbón en los barcos y pasó a estar obsoleta a finales de 1970. En progresivo estado de deterioro, sufrió importantes incendios en 2003 y 2010, y actualmente forma parte de la lista de patrimonio en riesgo.

Está situada en un área de importante interés ecológico. La interrupción del dragado del río en el área posibilitó la regeneración de las marismas y el área destaca

${ }^{21}$ Newcastle CC / Gateshead CC (2011): Green Infrastructure Study - River Tyne Report, p. 72.

22 El National Lottery Heritage Fund (NLHF) es un fondo que gestiona un porcentaje de los ingresos recaudados a través de la lotería nacional y que se destina al apoyo de iniciativas que tienen como eje central la puesta en valor del patrimonio cultural, pero que además cuentan con un fuerte componente social (educación, voluntariado, interpretación). La viabilidad económica y la autosuficiencia a largo plazo son elementos fundamentales a la hora de recibir esta financiación, que actualmente representa una de las fuentes de financiación económica más importantes en Reino Unido. 
no solo por la fauna que acoge, sino por su flora, de altísimo interés ecológico ${ }^{23}$. En 1996, dio comienzo un largo proceso de recuperación y la estructura pasó a manos del Tyne and Wear Preservation Trust ${ }^{24}$. Se organizan campañas de visibilización y concienciación sobre la importancia del monumento que incluyen intervenciones artísticas, proyectos con la universidad, actividades escolares, etc. Con el apoyo de distintos grupos locales, en 2014 se consiguió asegurar fondos para iniciar la recuperación en fases del monumento, convertirlo en observatorio de aves e incorporar la interpretación sobre la importancia ecológica e histórica del lugar. El proceso duró cuatro años y supuso una inversión de más de 750000 libras por parte de varias entidades. En la actualidad, la estructura es gestionada a través de un grupo local (Friends of Staithes), que se encarga de abrirla al público ${ }^{25}$ (figura 9).

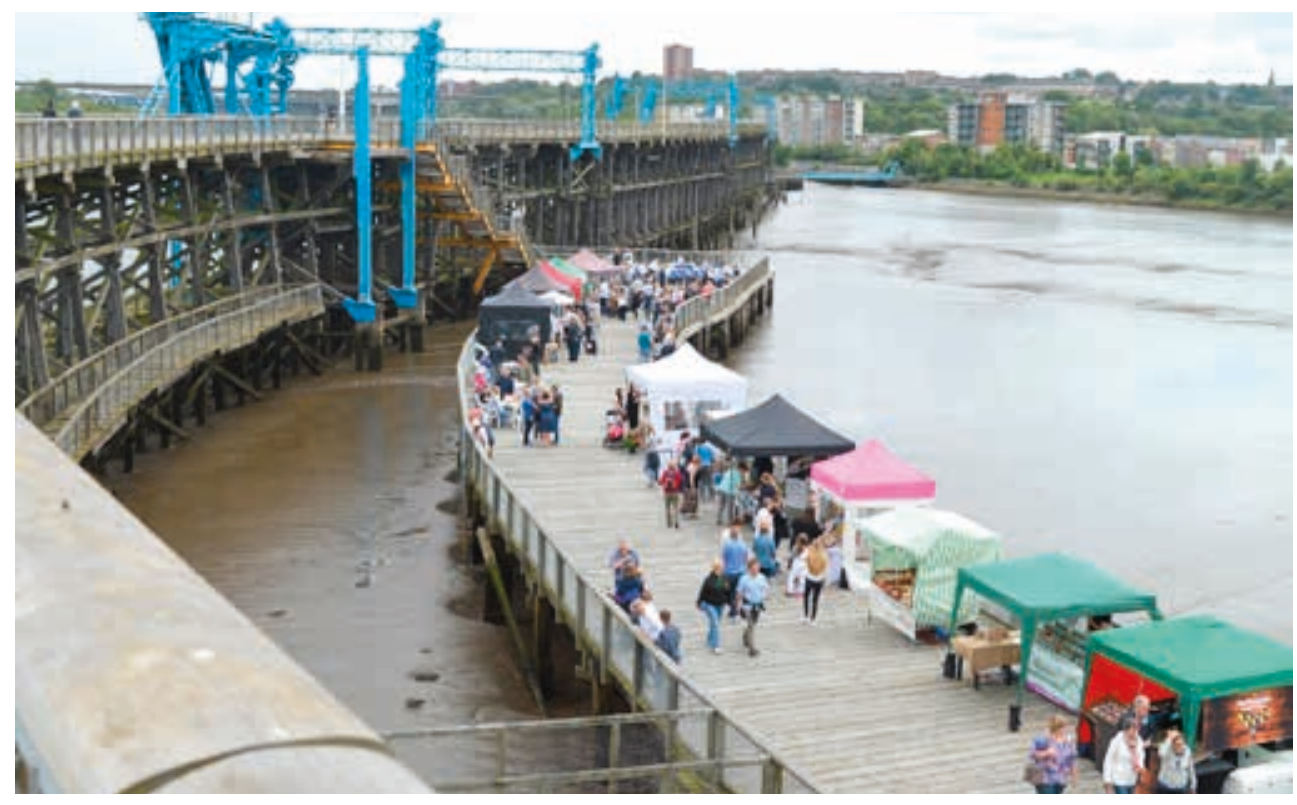

Figura 9. Dunston Staithes

23 Paradójicamente, debido a la alta concentración de minerales resultado de la actividad industrial.

24 Tyne and Wear Preservation Trust es una organización sin ánimo de lucro cuyo objetivo es «rescatar» edificios patrimonialmente importantes de su estado de abandono gracias al apoyo de asociaciones locales interesadas y encontrar un uso compatible para el edificio.

25 Es posible encontrar más información sobre las actividades y proyectos realizados en el siguiente sitio web: www.dunstonstaithes.org.uk. 


\section{Valle del río Allen (Allen Valleys Landscape Partnership)}

El proyecto se desarrolla en el valle del río Allen, un tributario del Tyne en su margen inferior, y se encuentra dentro del Área Natural de Belleza Destacada de los North Pennines, que desde 2015 pertenece además a la categoría de Geoparque de la UNESCO.

En el ámbito patrimonial, la región es importante por la explotación del plomo, que se remonta a las épocas romana y medieval, pero que adquiere máxima intensidad durante los siglos XVIII y XIX. De esta actividad quedan en el paisaje importantes ejemplos de arqueología industrial, como canalizaciones de varios kilómetros de longitud y chimeneas y construcciones relacionadas con los procesos de almacenaje, procesado y fundición del metal. Las rutas de transporte desde estas fundiciones hasta los embarques en puerto en el Tyne están ampliamente documentadas y algunas han sido recuperadas como rutas de senderismo ${ }^{26}$.

En cuanto a la naturaleza y el paisaje, es una zona de montañas suaves y ríos encajados, con vegetación baja (brezales mayoritariamente) que, en el siglo XIX, se popularizó para la cría y caza deportivas de aves entre las clases más acomodadas. Las turberas, características de este paisaje, tienen gran importancia a escala medioambiental no solo como importantes captadoras de dióxido de carbono o soporte de importante biodiversidad, sino también como registro arqueológico que se remonta a la edad del hielo.

El proyecto consiste en la recuperación e interpretación de un número de estructuras relacionadas con el patrimonio industrial de la región y forma parte de un proyecto más amplio ${ }^{27}$ que se organiza en torno a cuatro áreas: conservación y recuperación del patrimonio (natural y cultural) y aprovechamiento de recursos naturales (producción de energía limpia a partir de microhidráulicas); recuperación de tradiciones locales (música, tradición oral); mejora de la accesibilidad (basada en opciones sostenibles, rutas ciclables y vehículos eléctricos), y capacitación profesional (recuperación de técnicas tradicionales locales como construcción de muros de junta seca, rejuntado con mortero de cal, enlosados de pizarra, etc.).

\footnotetext{
26 https://explorenorthpennines.org.uk/node/533

${ }_{27}$ Más información en su página web: http://www.northpennines.org.uk/our-work/allenvalleyslps/allenvalleys-landscape-partnership/
} 
En 2014, recibe una subvención del $\mathrm{NLHF}^{28}$ de casi dos millones de libras para desarrollar el proyecto en cuatro años (figura 10).

\section{Blagdon Hall}

El proyecto persigue la recuperación paisajística de una residencia y su parque asociado. Ambos están incluidos en la lista de patrimonio cultural

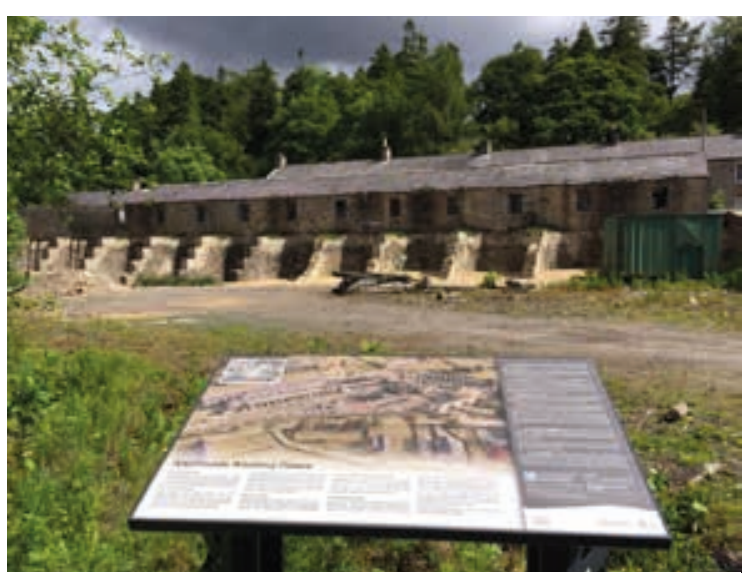

Figura 10. Allenheads. Estructuras recuperadas e interpretación nacional. La residencia, una mansión de tipo palladiano construida en $1730^{29}$, cuenta con el más alto grado de protección (grado I), mientras que el parque, modelo del paisajismo del siglo XVIII con intervenciones de Edwin Lutyens y Gertrude Jekyll en el siglo XX, ostenta un grado II ${ }^{30}$.

Considerablemente alterado por la actividad minera desarrollada en el área, el proyecto de recuperación paisajística busca integrar los movimientos de tierra resultado de la explotación a cielo abierto dentro del paisaje del parque, introduciendo un mirador como nuevo elemento formal en el parque. Su configuración final pretende respetar las vistas principales existentes. La reintroducción de arbolado esparcido busca recuperar el carácter tradicional de la secuencia de aproximación a la residencia, donde los grupos de árboles dejan entrever algunos elementos del parque, pero sin mostrarlo en su totalidad (figura 11).

${ }^{28}$ National Lottery Heritage Fund.

29 Con posteriores intervenciones de James Paine, 1752; James Wyatt, 1778-1791; John Dobson, 1820, y restaurada en 1948 por Robert Lutyens.

30 Existen tres grados de protección del patrimonio cultural en Inglaterra: grado I, para aquellos edificios considerados de interés excepcional y que representan el 2,5\% de los edificios en la lista de patrimonio nacional; grado II*, para edificios considerados de particular importancia y que representan el 5,8 \% del total y, finalmente, grado II o de interés especial, que constituyen el $91,7 \%$ restante. 


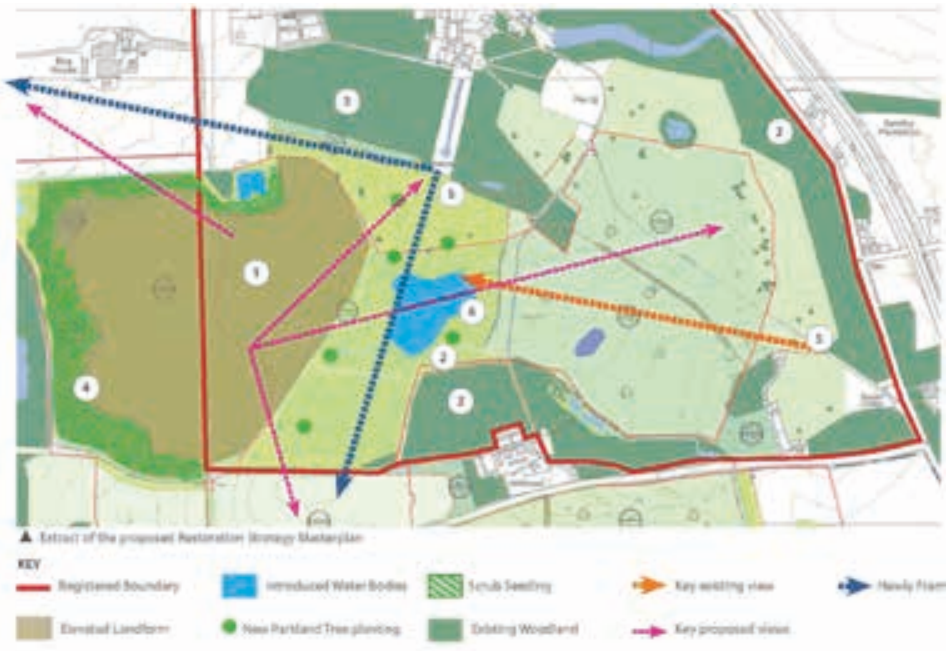

Figura 11. Blagdon Estate, Northumberland. Vistas existentes y creación de nuevas relaciones visuales

Desde el punto de vista ecológico, el proyecto considera la introducción de nuevos cuerpos de agua que tienen como función facilitar la conectividad ecológica a escala de paisaje, pero respetando los valores patrimoniales del parque (figura 12).

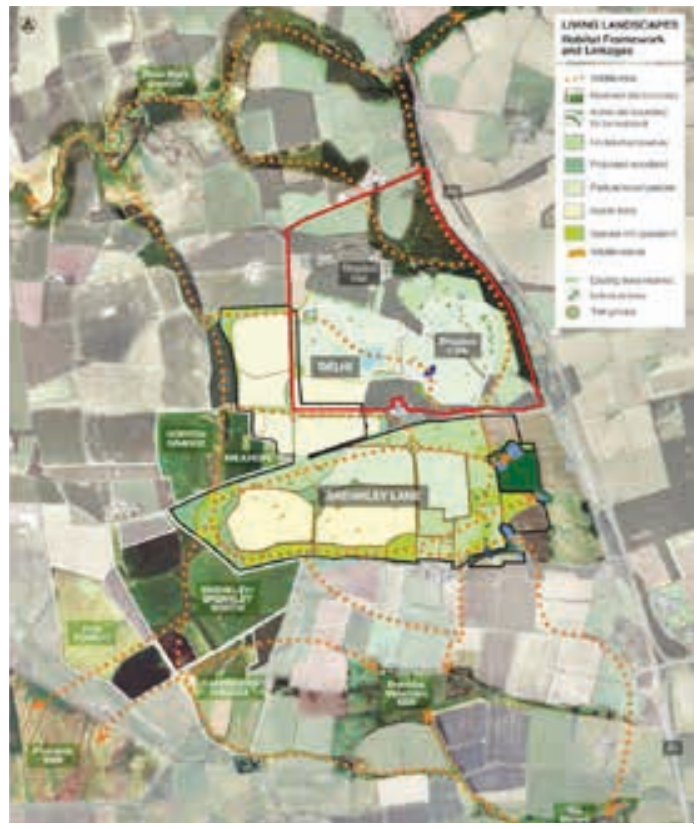

Figura 12. Blagdon Estate, Northumberland. Continuidad de los corredores ecológicos entre el paisaje a restaurar y el área circundante 


\section{REFERENCIAS BIBLIOGRÁFICAS}

DeFra / Environment Agency / Natural England (2016): National Parks: 8-point plan for England (2016 to 2020) (https://www.gov.uk/government/publications/national-parks-8-point-plan-forengland-2016-to-2020).

Ministry of Housing, Communities \& Local Government (2018): National Planning Policy Framework (https://assets.publishing.service.gov.uk/government/uploads/system/uploads/attachment_data/ file/779764/NPPF_Feb_2019_web.pdf).

Natural England (2010): Green Belts: a greener future - main report (NE196) (http://publications. naturalengland.org.uk/publication/38005).

Natural England (2013): NCA Profile: 14 Tyne and Wear Lowlands (NE483), (http://publications. naturalengland.org.uk/publication/4683608954503168?category=587130).

Newcastle City Council / Gateshead Council (2011): Green Infrastructure Study - River Tyne Report, Newcastle-Gateshead (https://www.gateshead.gov.uk/media/1862/162-SD-NewcastleGateshead-GreenInfrastructure-Study-River-Tyne-Report/pdf/162.-SD-NewcastleGateshead-Green-Infrastructure-StudyRiver-Tyne-Report.pdf).

Skelton, Leona (2017): «Stories of Life, Work and Nature Before and After the Clean-up of North East England's River Tyne, 1940-2015", en Katie Holmes / Heather Goodall (eds.), Telling Environmental Histories. Intersections of Memory, Narrative and Environment, London, Palgrave Macmillan, 153-178.

Veldpaus, Loes / Philippa Carter / John Pendlebury (2018): Country report England: Newcastle upon Tyne, Gateshead, North Tyneside, South Tyneside Urban Landscape: The Tyne Landscape as a case study, England, JPI PICH project, Newcastle University, Newcastle upon Tyne (https://planningandheritage.wordpress. com/pich-2/cases/). 

II PARTE.

A POSTA EN VALOR DO PATRIMONIO CULTURAL DOS RIOS EN GALICIA 



\section{INVENTARIO E ESTUDO DE INFRAESTRUTURAS TRADICIONAIS DE CARÁCTER HIDRÁULICO-INDUSTRIAL EN GALICIA}

Roberto Arias Sánchez

Olalla Mosquera Barreiro

Augas de Galicia. Consellería de Infraestruturas

e Mobilidade. Xunta de Galicia

Laura M. Garrido Fernández

ICEACSA Consultores, S. L. U.

Jorge Núñez Ares

AIN Active S. L.

DOI: 10.17075/pvpcr.2021.005 



\section{INTRODUCIÓN}

As infraestruturas hidráulicas de carácter industrial existentes ao longo de todos os ríos de Galicia conforman un patrimonio de indubidable valor nos aspectos etnográfico e histórico-cultural. Cómpre salientar a súa importancia tanto desde o punto de vista cuantitativo, polo número de instalacións existentes, como cualitativo, con base en aspectos ben arquitectónicos, ben históricos ou relacionados coa enxeñaría hidráulica.

Neste marco, pretendeuse desenvolver un traballo que permitise a identificación, inventario, caracterización e posterior definición de actuacións para a posta en valor e enriquecemento do patrimonio que conforman estas instalacións e, paralelamente, dos ríos e, en xeral, a contorna na que se enmarcan, dando cumprimento, por tanto, ao obxectivo sinalado de conservar e mellorar o patrimonio natural fluvial.

$\mathrm{Na}$ área xeográfica galega, as construcións tradicionais para o aproveitamento dos recursos hídricos ou as instalacións daquelas industrias dependentes da forza dos cursos de auga constitúen os mellores exemplos para entender a continuidade entre arquitectura e territorio que caracteriza a paisaxe agraria preindustrial de Galicia.

A continuación, indícanse os traballos realizados para o inventariado e estudo das infraestruturas hidráulicas.

\section{INVENTARIO DE INFRAESTRUTURAS HIDRÁULICAS TRADICIONAIS}

\subsection{Inventario a partir de fontes documentais}

Realizouse un baleirado documental de diversas fontes de información para a elaboración dun inventario inicial.

\subsubsection{Recursos bibliográficos}

Unha vez consultada toda a bibliografía existente relacionada coas infraestruturas hidráulicas tradicionais de carácter industrial, incluíronse no estudo obras de referencia pola súa importancia na caracterización e análise de enxeños hidráulicos. 


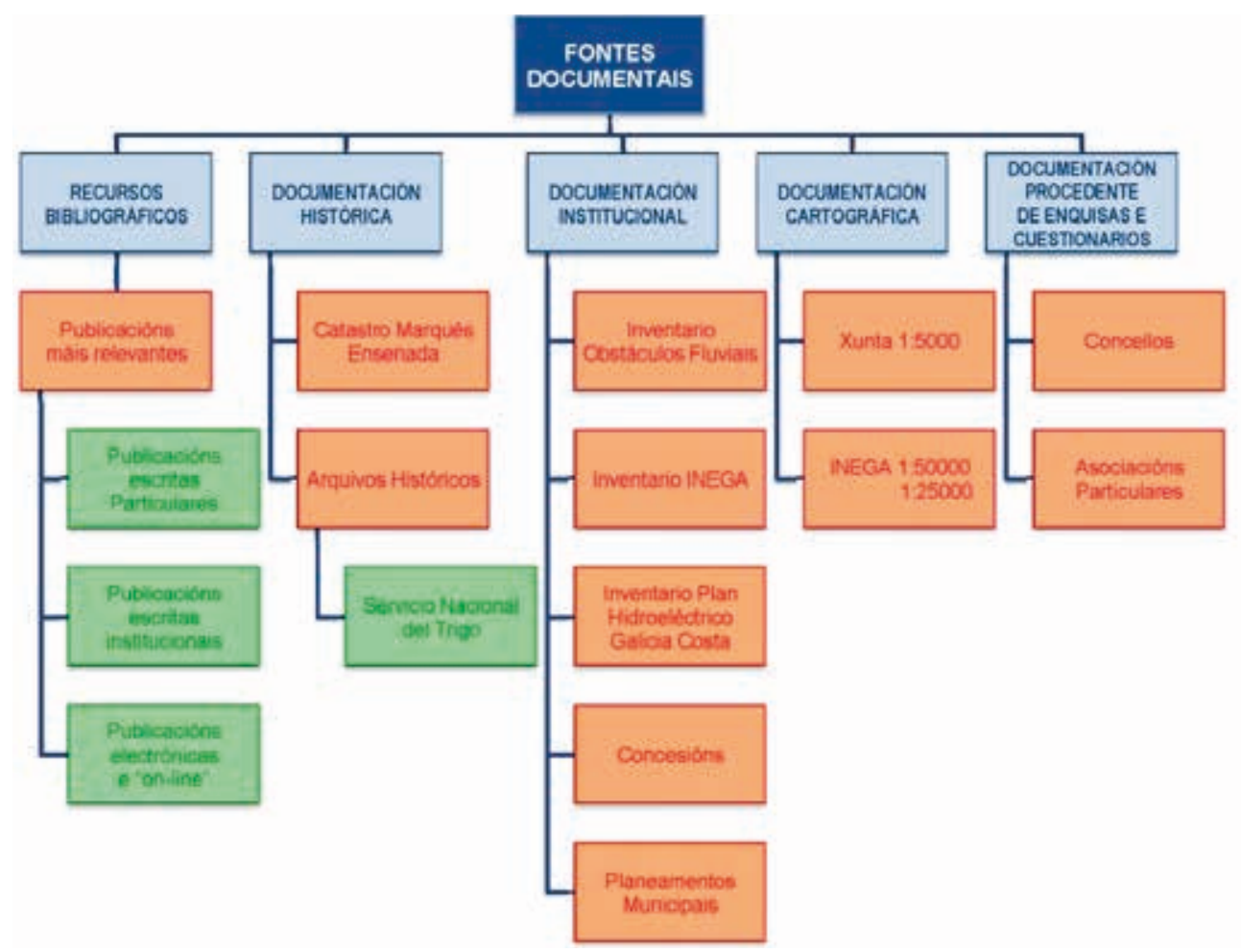

Figura 1. Esquema das fontes documentais consultadas

\subsubsection{Documentación histórica}

2.1.2.1. Catastro del Marqués de la Ensenada (s. XVIII)

Respuestas Generales del Catastro del Marqués de la Ensenada constitúe a máis antiga e exhaustiva enquisa dispoñible sobre as poboacións da coroa de Castela a mediados do século XVIII. Consta de 40 preguntas, pero para o presente traballo a que interesa é a número 17 , onde se pedía información sobre os «molinos harineros, o de papel, batanes u otros artefactos en el término». O catastro estrutúrase por provincias e localidades, o que en Galicia corresponde ás parroquias.

O proceso de baleirado do Catastro de Ensenada constou das seguintes fases:

— Primeira fase: recompilación da información. 
- Segunda fase: lectura de toda a documentación existente e posterior elaboración dunha ficha resumo cos datos máis relevantes (localización, tipo de artefacto, tipo de produción...).

- Terceira e última fase: inicio da identificación e adxudicación das parroquias presentes no catastro aos seus concellos actuais.

\begin{tabular}{|l|c|}
\hline \multicolumn{1}{|c|}{ TIPOLOXÍA } & N.* DE ELEMENTOS \\
\hline N. ${ }^{\circ}$ MUÍNÓS & 15263 \\
\hline N.o ACEAS & 16 \\
\hline N.o BATÁNS & 173 \\
\hline N.o PESQUEIRAS & 188 \\
\hline No. MAZOS/FERRARÍAS & 12 \\
\hline N.o SALINAS & 3 \\
\hline
\end{tabular}

Táboa 1. Tipos de enxeños hidráulicos no Catastro de Ensenada

Segundo os resultados obtidos, o Catastro del Marqués de la Ensenada contabiliza para Galicia un total de 15655 infraestruturas hidráulicas.

\subsubsection{Arquivos históricos. Servicio Nacional del Trigo (s. xx)}

A información atopada nos arquivos históricos céntrase nos expedientes do antigo Servicio Nacional del Trigo do Servicio Nacional de Productos Agrarios (SENPA). Todos estes expedientes do SENPA están depositados nos arquivos provinciais dependentes da Xunta de Galicia.

Desde a década de 1940, é obrigatorio solicitar a inscrición dos muínos no SENPA para poder seguir moendo, motivo polo cal se converten na fonte histórica máis importante do século Xx. Para optar á inscrición do muíño, cada propietario tiña que cubrir unha solicitude dirixida ao xefe provincial do SENPA, quen a analizaba e decidía se a autorizaba ou non. Para realizar o baleirado desta fonte histórica, utilizáronse estas solicitudes e as fichas de apertura de expediente de cada muíño.

Segundo os resultados obtidos, o Servicio Nacional del Trigo contabiliza para Galicia un total de 4031 elementos. 


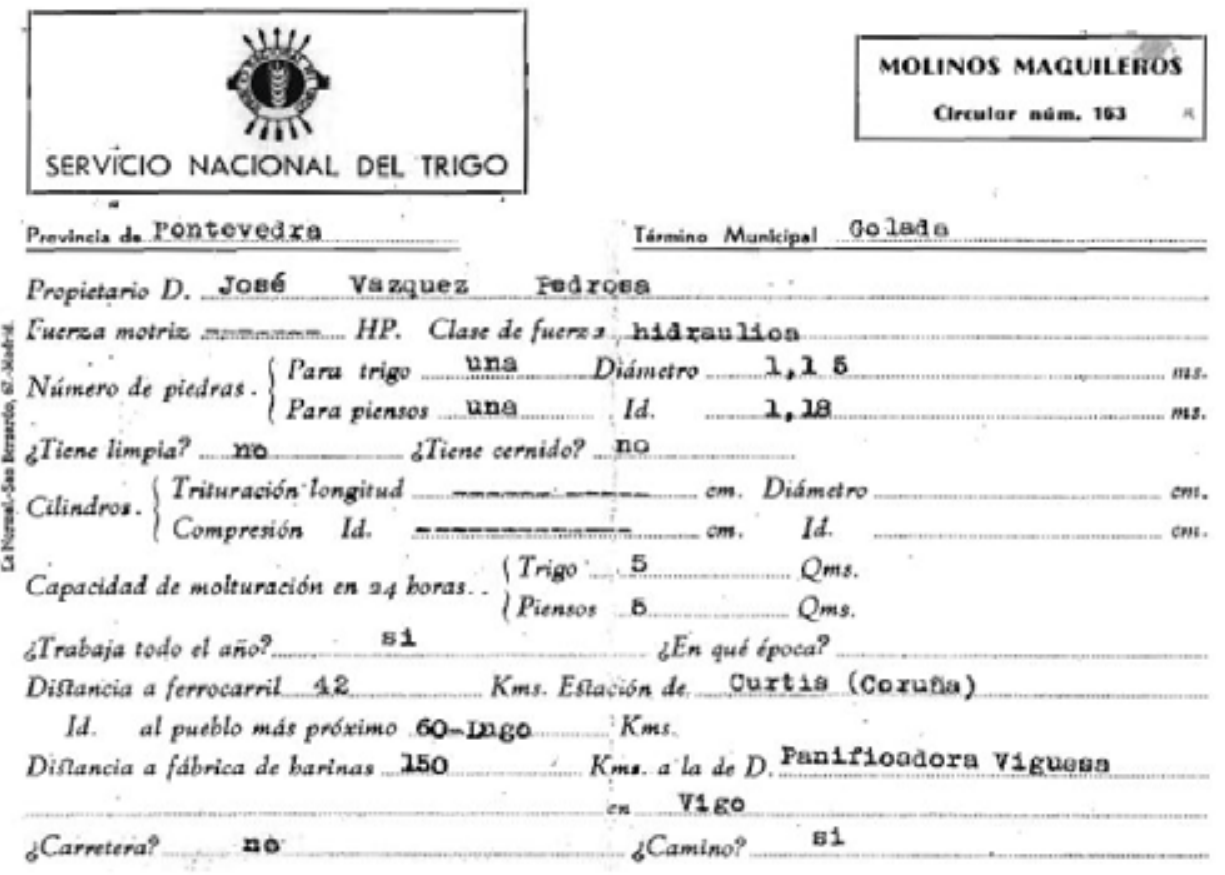

Figura 2. Ficha de exemplo do Servicio Nacional del Trigo dun muíño no concello de Agolada (Pontevedra)

\begin{tabular}{|l|c|}
\hline \multicolumn{1}{|c|}{ PROVINCIA } & N.o DE ELEMENTOS \\
\hline A CORUNA & 1267 \\
\hline LUGO & 1697 \\
\hline OURENSE & 802 \\
\hline PONTEVEDRA & 265 \\
\hline GALICIA & $\mathbf{4 0 3 1}$ \\
\hline
\end{tabular}

Táboa 2. Distribución de elementos por provincia

\subsubsection{Documentación institucional}

2.1.3.1. Inventario de Obstáculos de Especies Fluviais

O Inventario de Obstáculos de Especies Fluviais (presas e azudes) ten como obxectivo determinar que obstáculos poden limitar o remonte do río de migradores. 
Este inventario foi elaborado pola Consellería de Medio Ambiente da Xunta de Galicia.
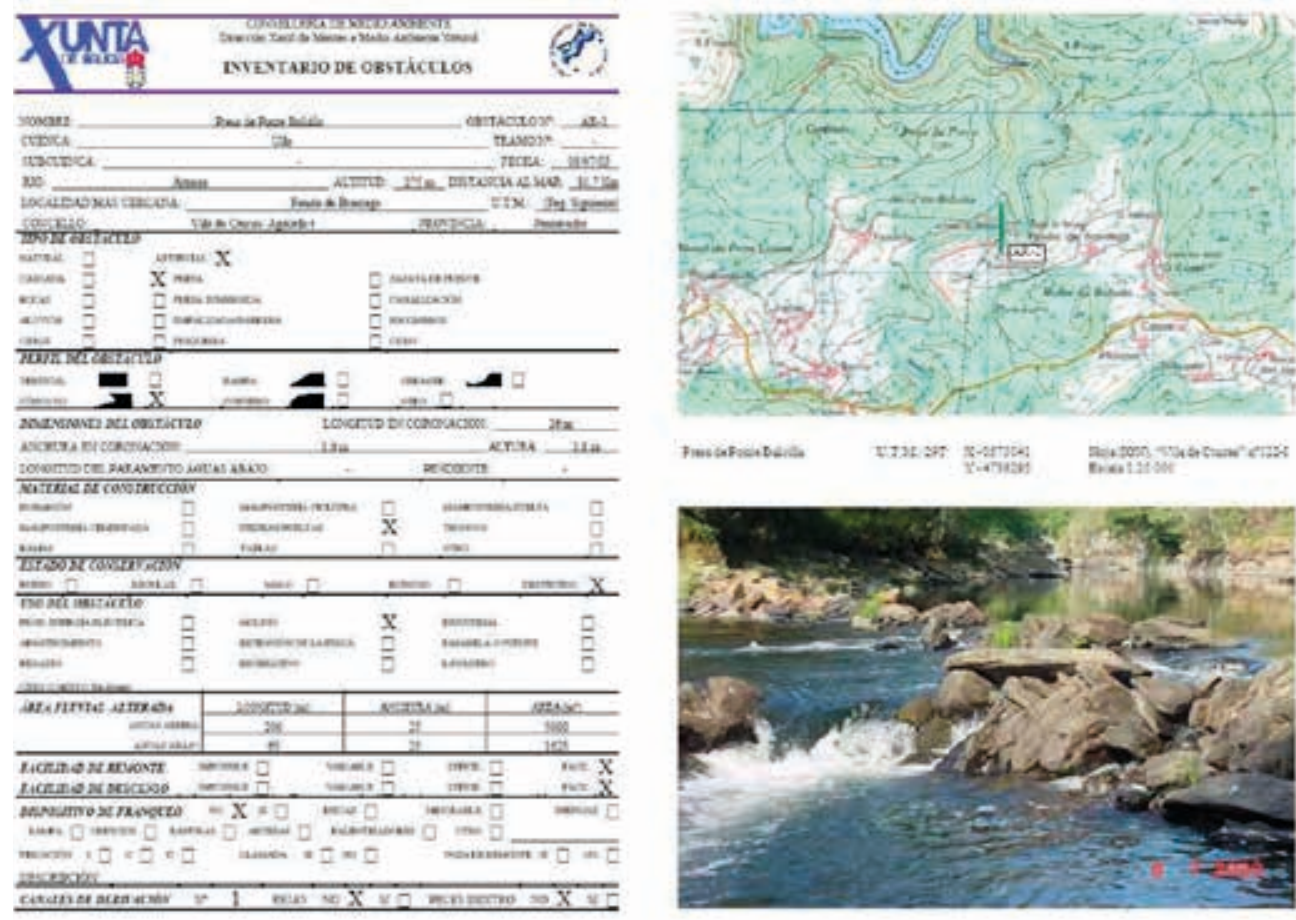

Figura 3. Modelo de ficha e localización dun obstáculo fluvial

\subsubsection{Inventario INEGA}

O Instituto Enerxético de Galicia (INEGA) dispón do Atlas Enerxético de Galicia, ideado como un sistema de información xeográfica das distintas instalacións enerxéticas existentes en Galicia. Esta fonte documental solápase en certa medida co inventario de obstáculos nos datos de presas e azudes; no entanto, a diferenza da fonte anterior, aquí só están recollidos elementos vinculados coa produción de enerxía. 


\begin{tabular}{|l|c|c|c|c|c|}
\hline \multicolumn{1}{|c|}{ PROVINCIA } & $\begin{array}{c}\text { HIDROELÉCTRICAS } \\
\text { MÁIS DE 10 MW }\end{array}$ & $\begin{array}{c}\text { HIDROELÉCTRICAS } \\
\text { MENOS DE 10 MW }\end{array}$ & $\begin{array}{c}\text { CÁMARAS } \\
\text { DE CARGA }\end{array}$ & ENCOROS & $\begin{array}{c}\text { PRESAS/ } \\
\text { AZUDES }\end{array}$ \\
\hline A CORUNA & 7 & 33 & 23 & 21 & 32 \\
\hline LUGO & 6 & 26 & 20 & 12 & 26 \\
\hline OURENSE & 22 & 26 & 24 & 34 & 41 \\
\hline PONTEVEDRA & 4 & 28 & 23 & 10 & 27 \\
\hline GALICIA & $\mathbf{3 9}$ & $\mathbf{1 1 3}$ & $\mathbf{9 0}$ & 77 & $\mathbf{1 2 6}$ \\
\hline
\end{tabular}

Táboa 3. Resumo dos elementos inventariados polo INEGA

\subsubsection{Inventario do Plan Hidroeléctrico Galicia Costa}

Neste plan están recollidas numerosas centrais hidroeléctricas e a información coincide coa do inventario realizado polo INEGA, anteriormente comentado.

\subsubsection{Concesións}

Durante as tarefas de documentación, consultáronse os libros de concesións hidráulicas de Augas de Galicia, que constan de dous volumes de máis de 200 páxinas cada un, con inscricións que van desde finais do século XIX até a década de 1970, ordenados por río e bacía.

O proceso de baleirado tivo dúas etapas:

1. Fotografado dos libros.

2. Baleirado da información.

\begin{tabular}{|l|c|}
\hline \multicolumn{1}{|c|}{ TIPOLOXÍA } & N.o DE ELEMENTOS \\
\hline MUÍNOOS & 509 \\
\hline BATÁNS & 1 \\
\hline FORZA MOTRIZ & 86 \\
\hline SERRAS/SERRADOIROS & 22 \\
\hline CENTRAL ELÉCTRICA & 223 \\
\hline MALLA/CRIBA & 8 \\
\hline PISCIFACTORÍA & 7 \\
\hline OUTROS & 5 \\
\hline
\end{tabular}

Táboa 4. Número de elementos segundo a súa tipoloxía 
Segundo os resultados obtidos, os libros de concesións de Augas de Galicia contabilizan un total de 861 elementos.

\subsubsection{Plans municipais}

A consulta dos plans municipais dos concellos ou, na súa ausencia, das normas subsidiarias provinciais vixentes debería ser unha das fontes máis importantes de catalogación de elementos patrimoniais dada a súa importancia legal en canto á protección do patrimonio local.
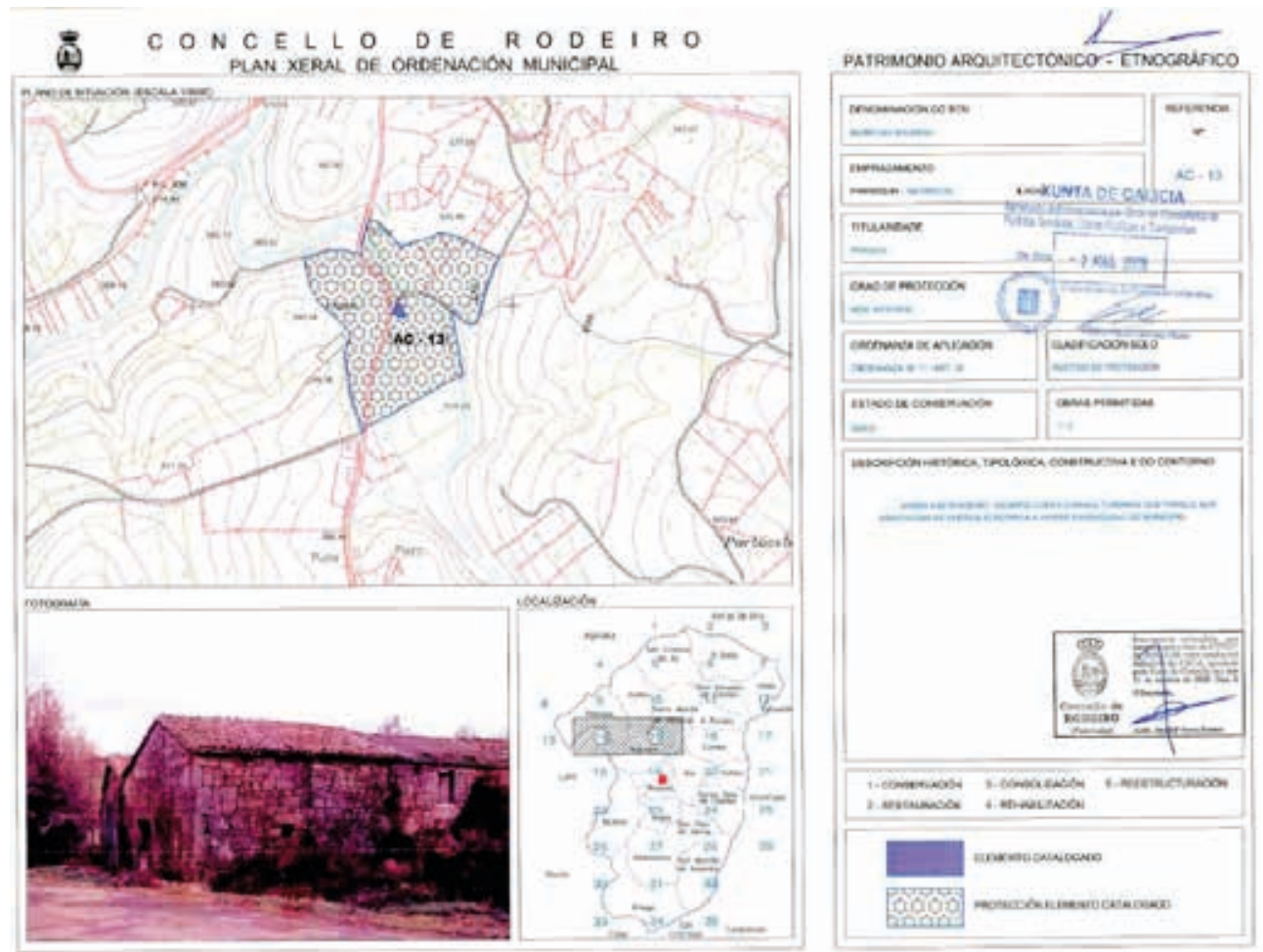

Figura 4. Modelo de ficha-catálogo do plan de Rodeiro (Pontevedra)

Segundo os datos obtidos dos plans vixentes, o número total de elementos recollidos sería de 1525 infraestruturas, distribuídas da seguinte forma: 


\begin{tabular}{|l|c|}
\hline \multicolumn{1}{|c|}{ TIPOLOXÍA } & N. ${ }^{\circ}$ DE ELEMENTOS \\
\hline MUÍNOSOS & 1313 \\
\hline BATÁNS & 4 \\
\hline PRESAS/AZUDES & 1 \\
\hline PESQUEIRAS & 176 \\
\hline SERRADOIROS & 2 \\
\hline MINICENTRAIS & 6 \\
\hline CURTIDOIROS & 14 \\
\hline MAZO/MACHUCO/MOA & 5 \\
\hline FÁBRICA DE PAPEL & 2 \\
\hline CANLE/ACUEDUTO & 2 \\
\hline
\end{tabular}

Táboa 5. Número de elementos segundo a súa tipoloxía

\subsubsection{Documentación cartográfica}

A información cartográfica utilizada para a realización deste estudo foi a dispoñible para todo o territorio galego.

\subsubsection{Cartografía 1:5000 (Xunta de Galicia)}

A elaboración dos planos baseouse no deseño dun Geographic Information System (GIS), no que se definiron os criterios para localizar todos os elementos que puidesen formar parte do patrimonio hidráulico.

O deseño do GIS tivo as seguintes fases:

1. a fase. Depuración cartográfica. Referente ás edificacións, cursos fluviais e rede viaria.

2. ${ }^{a}$ fase. Aplicación das pautas de localización das posibles edificacións que puidesen ser elementos de orixe hidráulica-industrial.

3. ${ }^{\mathrm{a}}$ fase. Codificación dos elementos resultantes.

Obtívose así un plano inicial cuns criterios de localización homoxéneos para toda Galicia.

Segundo os resultados obtidos, a cartografía 1:5000 da Xunta de Galicia contabiliza un total de 15911 elementos. 
INVENTARIO E ESTUDO DE INFRAESTRUTURAS TRADICIONAIS DE CARÁCTER HIDRÁULICO-INDUSTRIAL EN GALICIA

\begin{tabular}{|l|c|}
\hline \multicolumn{1}{|c|}{ PROVINCIA } & N.o DE ELEMENTOS \\
\hline A CORUNAA & 3055 \\
\hline LUGO & 4613 \\
\hline OURENSE & 3784 \\
\hline PONTEVEDRA & 4459 \\
\hline GALICIA & $\mathbf{1 5 9 1 1}$ \\
\hline
\end{tabular}

Táboa 6. Distribución de elementos por provincias

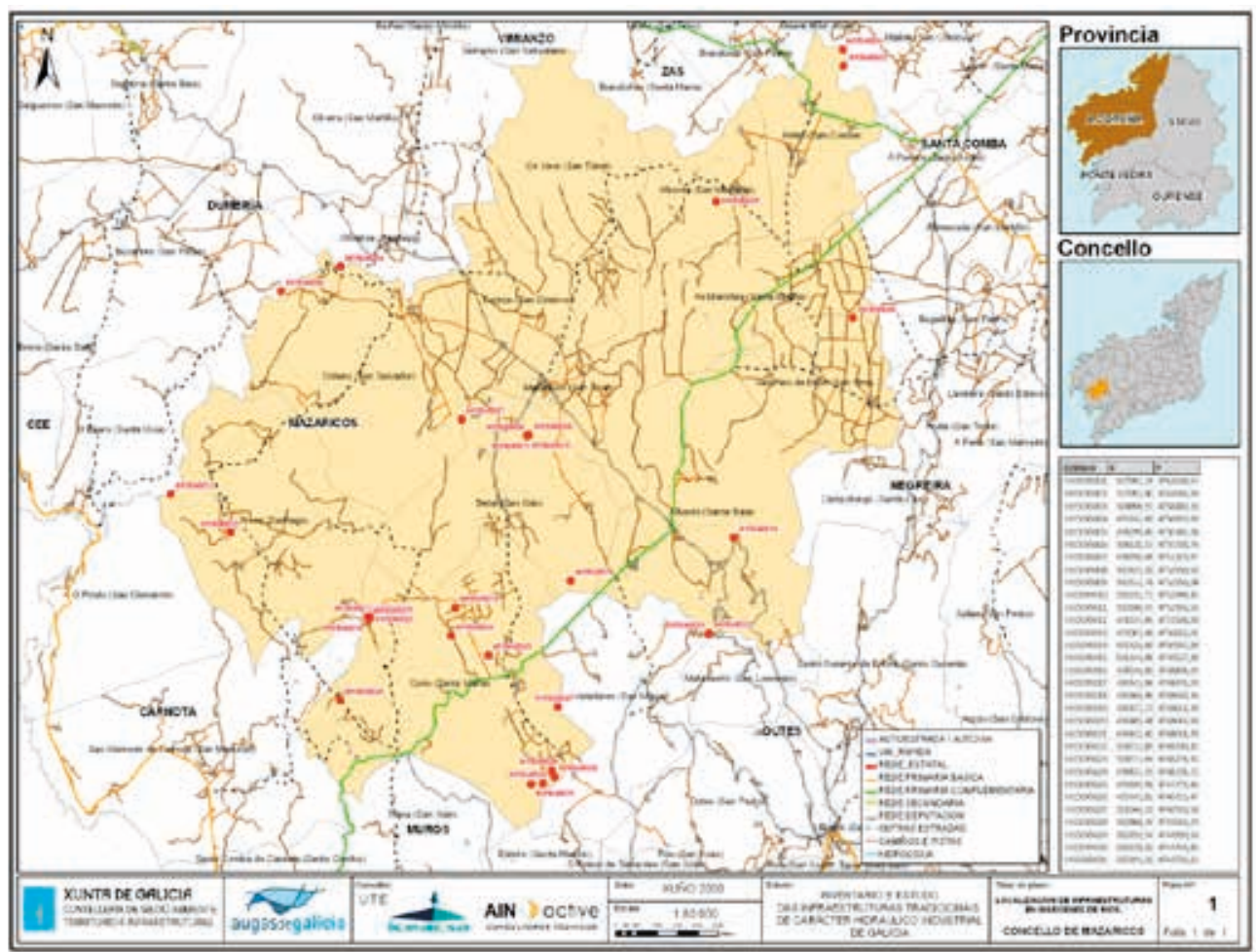

Figura 5. Exemplo de plano base utilizado durante os traballos de recompilación de información

\subsubsection{Cartografía 1:50 000 e 1:25 000 (IGN)}

O mapa topográfico nacional (MTN) a escala 1:25 000 e 1:50 000 do Instituto Xeográfico Nacional (IGN) en formato vectorial e raster é unha das fontes carto- 
gráficas dispoñibles máis importante que existen en España. Nel están representados numerosos muíños hidráulicos. Para realizar o inventario inicial, utilizouse soamente a cartografía a escala 1:25 000, pero tratáronse as dúas fontes por igual para comparar os resultados obtidos.

\begin{tabular}{|l|c|c|}
\hline \multicolumn{1}{|c|}{ PROVINCIA } & $\begin{array}{c}\text { N. } \text { DE ELEMENTOS } \\
\text { DO MTN 25 000 }\end{array}$ & $\begin{array}{c}\text { N.o DE ELEMENTOS } \\
\text { DO MTN 50 000 }\end{array}$ \\
\hline A CORUNA & 2464 & 2348 \\
\hline LUGO & 1096 & 1100 \\
\hline OURENSE & 321 & 337 \\
\hline PONTEVEDRA & 1311 & 1387 \\
\hline GALICIA & $\mathbf{5 1 9 2}$ & $\mathbf{5 1 7 2}$ \\
\hline
\end{tabular}

Táboa 7. Número de elementos segundo a fonte cartográfica

Segundo os resultados obtidos, tanto a cartografía 1:25 000 coma a 1:50 000 do IGN contabilizan un total de 5172 elementos.

2.1.5. Documentación procedente de enquisas e cuestionarios (concellos, organismos privados e particulares)

Para comezar as tarefas de sondaxe de información, confeccionouse un modelo de enquisa que foi enviado aos concellos e outras institucións. $\mathrm{Na}$ enquisa preguntábanse as características xerais do patrimonio hidráulico-industrial existente no seu ámbito territorial.

Con toda a información obtida por medio de enquisas ou pescudas elaborouse unha táboa de 1718 elementos de carácter hidráulico-industrial correspondentes a 53 concellos.

\subsubsection{Elaboración do catálogo previo}

Tras o baleirado documental, procedeuse á elaboración dun catalogo inicial no que se inclúe a información de todas as fontes documentais. A maiores inclúense, aproximadamente, uns 200 elementos recollidos en fontes documentais a través de Internet.

O catálogo estrutúrase da seguinte maneira: 
A. Unha primeira parte resumo, onde se computan todos os elementos obtidos nas diferentes fontes documentais, en cada concello. O número total de infraestruturas hidráulicas de rexistros de infraestruturas documentadas ascende a máis de 30000 .

B. Unha segunda parte daqueles que se recompilou maior información e que pasan a formar parte dun catálogo inicial. Este catálogo está formado por ao redor de 3100 infraestruturas, reflectidas en fichas semellantes á que se amosa a continuación.

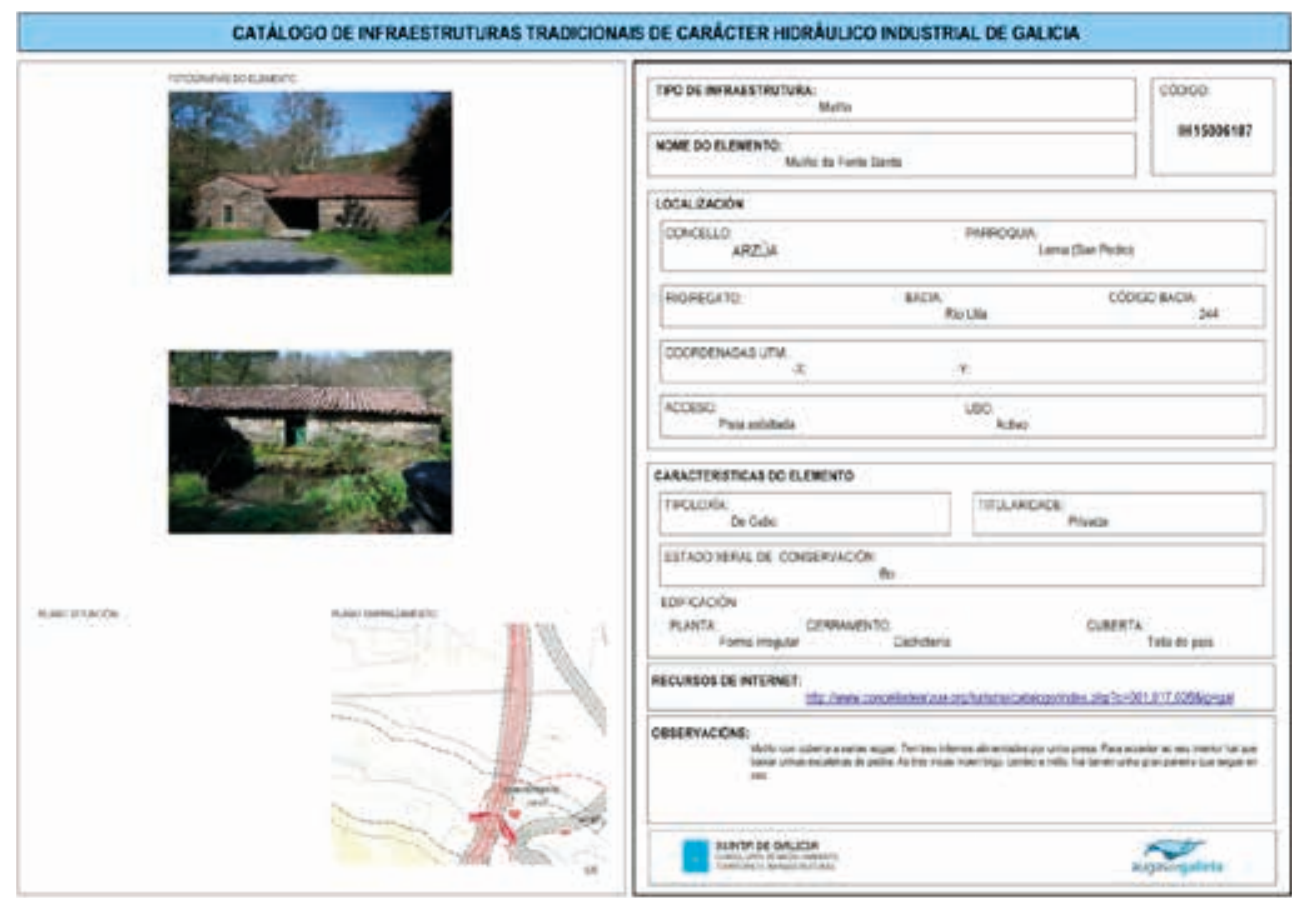

Figura 6. Ficha de exemplo do catálogo previo

\subsection{Inventario a partir de visitas de campo}

A partir das visitas de campo, complétase o inventario inicial extraído das fontes documentais.

A metodoloxía de traballo para a obtención da información destinada á elaboración do novo catálogo foi a seguinte:

- Contacto cos representantes municipais. 
- Localización das infraestruturas máis representativas mediante a información previa das fontes documentais e a existente no propio concello.

Durante a visita de campo, recompílase a seguinte información:

1. Coordenadas de situación

2. Plano de planta

3. Medidas interiores e exteriores

4. Reportaxe fotográfica

Así mesmo, realízase unha acta de visita na que se recollen os elementos visitados, os representantes que van como acompañantes durante esta e unha pequena descrición destes elementos.

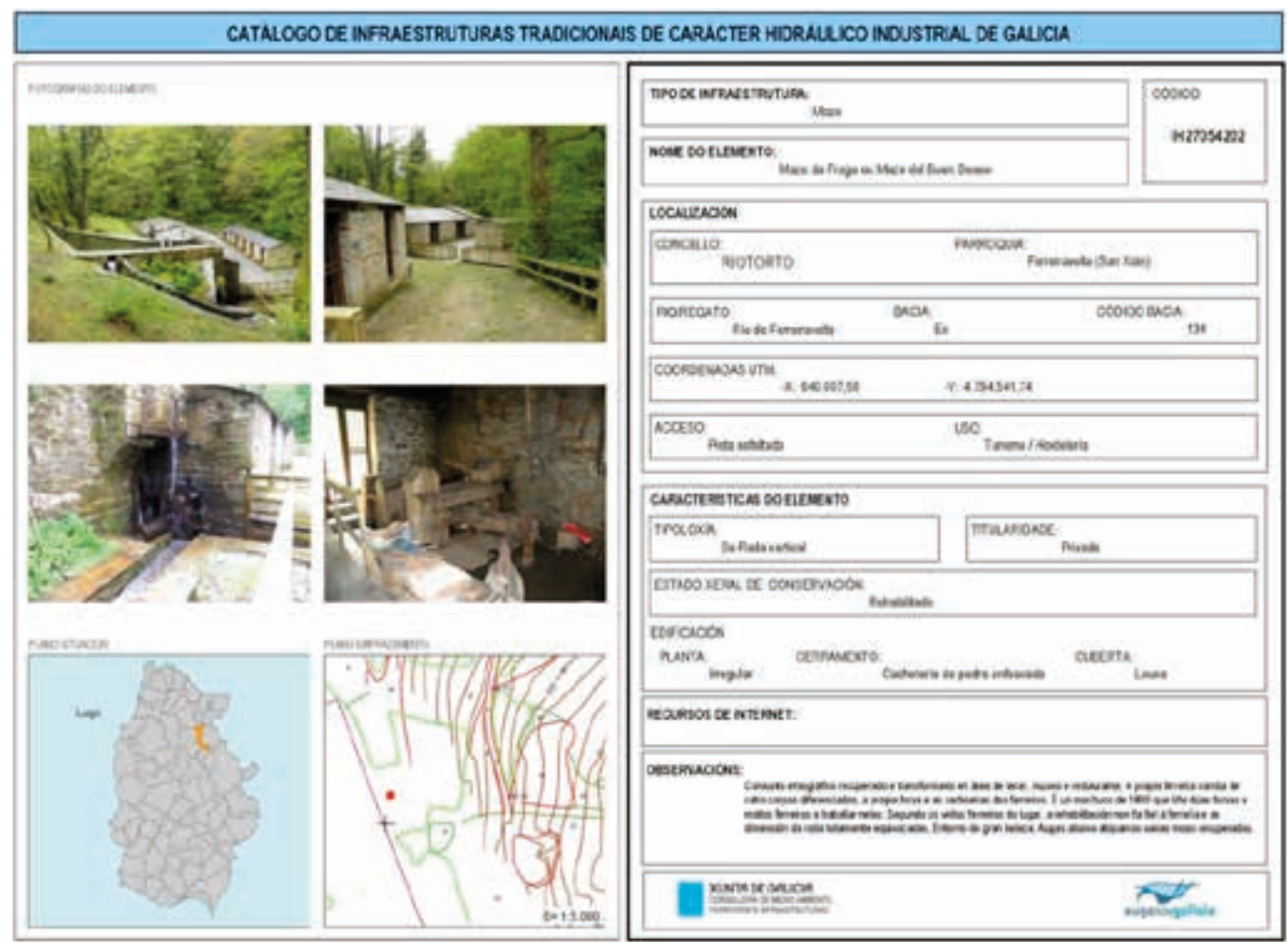

Figura 7. Ficha exemplo de ficha catálogo 


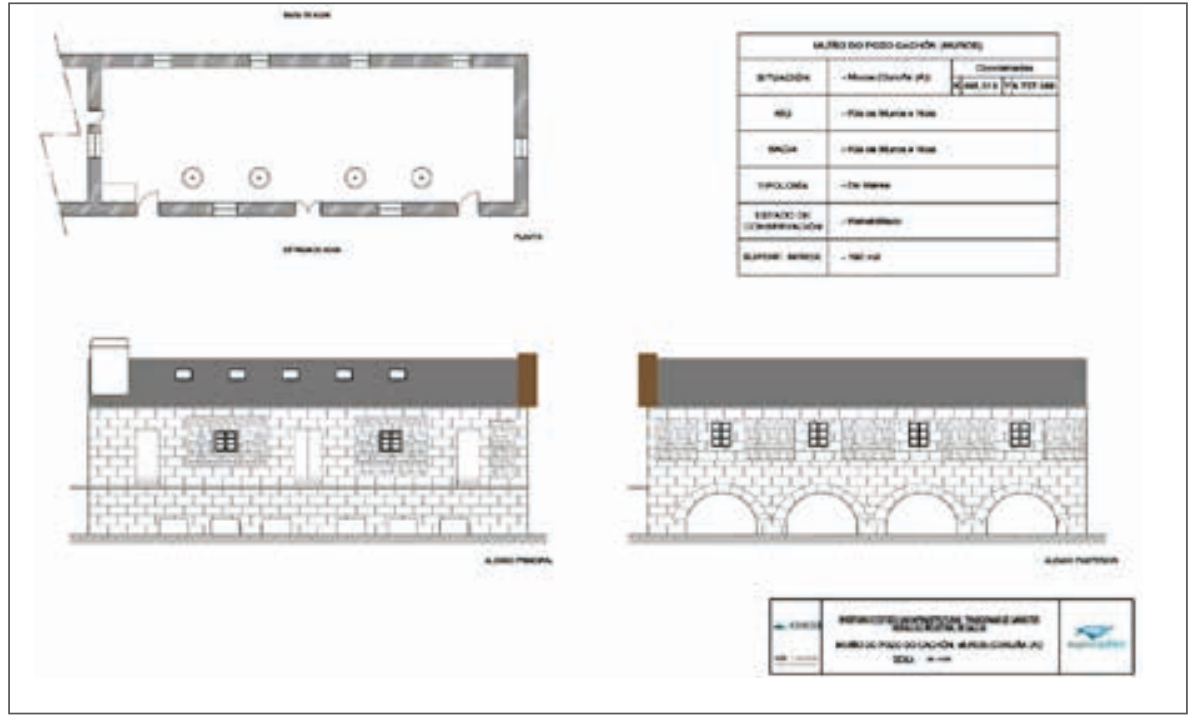

Figura 8. Exemplo de plano

Esta mesma ficha é exportada ao programa Google Earth, que permite acceder a través de imaxes satélite á localización dos distintos elementos.

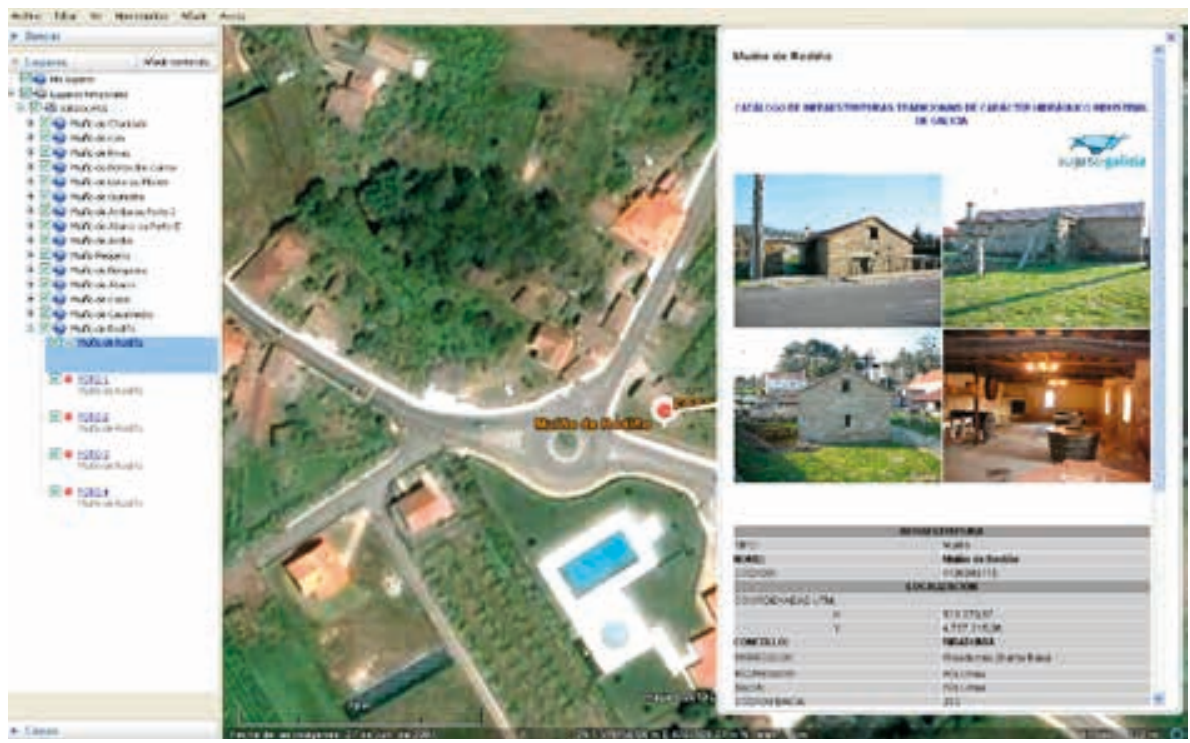

Figura 9. Exemplo de ficha de catálogo en formato Google Earth 
Neste novo inventario, recóllese un total de case 1100 elementos, entre os que se atopan muínos, batáns, mazos, fábricas de papel, fábricas de luz, serradoiros, azudes, presas e pesqueiras.

\begin{tabular}{|l|c|c|c|c|c|c|c|}
\hline \multicolumn{1}{|c|}{ Provincia } & $\begin{array}{c}\text { Muíńos } \\
\text { de río }\end{array}$ & $\begin{array}{c}\text { Muíños } \\
\text { de marea }\end{array}$ & Batáns & Serradoiros & Ferrarías & Pesqueiras & $\begin{array}{c}\text { Mazos/ } \\
\text { machucos }\end{array}$ \\
\hline A CORUNA & 319 & 3 & 3 & 1 & - & - & 2 \\
\hline LUGO & 172 & 1 & 1 & 6 & 3 & 2 & 7 \\
\hline OURENSE & 254 & - & - & 3 & 3 & - & 1 \\
\hline PONTEVEDRA & 215 & 4 & 1 & 5 & - & 3 & - \\
\hline TOTAL & $\mathbf{9 6 0}$ & $\mathbf{8}$ & $\mathbf{5}$ & $\mathbf{1 5}$ & $\mathbf{6}$ & $\mathbf{5}$ & $\mathbf{1 0}$ \\
\hline \multicolumn{1}{|c|}{ Provincia } & $\begin{array}{c}\text { Fábricas } \\
\text { de coiros }\end{array}$ & $\begin{array}{c}\text { Fábricas } \\
\text { de luz }\end{array}$ & $\begin{array}{c}\text { Fábricas } \\
\text { de papel }\end{array}$ & Azudes & $\begin{array}{c}\text { Minicen- } \\
\text { trais/CH }\end{array}$ & Acuedutos & Lavadoiros \\
\hline A CORUNA & 3 & 2 & 2 & 5 & 10 & 2 & 1 \\
\hline LUGO & - & 5 & - & 1 & 4 & - & - \\
\hline OURENSE & 7 & 3 & 2 & 7 & 10 & - & - \\
\hline PONTEVEDRA & - & 1 & - & 3 & 2 & - & - \\
\hline TOTAL & $\mathbf{1 0}$ & $\mathbf{1 1}$ & $\mathbf{4}$ & $\mathbf{1 6}$ & $\mathbf{2 6}$ & $\mathbf{2}$ & $\mathbf{1}$ \\
\hline
\end{tabular}

Táboa 8. Resumo por provincias e tipoloxías

\section{VALORACIÓN DE INFRAESTRUTURAS E SELECCIÓN DAS MÁIS REPRESENTATIVAS}

\subsection{Valoración de infraestruturas inventariadas}

Coa totalidade dos elementos visitados, procedeuse a unha valoración multifactorial baseada en índices numéricos que permitiu coñecer o valor estimado ou patrimonial de cada unha das infraestruturas.

Os aspectos que se tiveron en conta foron os seguintes:

- Singularidade

○ A. Elemento único.

- B. Máxima puntuación, tipoloxía escasamente representada en Galicia. Estes elementos veñen sendo os muíños de marea, os batáns e os machucos, os mazos e demais estruturas relacionadas co traballo do ferro.

○ C. Valor dependendo de se integran conxuntos que maximizan o aproveitamento da auga. 
- Valor arquitectónico

○ A. Edificación:

- Muros: cantaría, perpiaños, cachotaría de pedra etc.

- Cuberta: pedra (lousa, laxes), tella etc.

- Estrutura de madeira: cimbros, correas etc.

- Ocos: portas, ventás etc.

- B. Infraestrutura hidráulica:

- Canles, cubos etc.

A complexa e delicada configuración construtiva do conxunto de cada unha destas instalacións é consecuencia da continuidade entre a arquitectura da instalación hidráulica e a maquinaria que procesa o recurso. Na maioría dos casos, a infraestrutura e a mecánica compoñen unha unidade que comparte técnicas e materiais.

A técnica das solucións vai refinándose progresivamente desde as canles e os muros até as comportas, pas ou rodas, formando unha unidade. Se ben os seus elementos son perfectamente distinguibles, a técnica das súas solucións fainos interdependentes e, polo tanto, ten peso na valoración dos exemplos catalogados, a integridade dos sistemas construtivos tradicionais e o seu nivel de alteración.

Mediante a integración dos datos obtidos do GIS, cada infraestrutura ten unha valoración multifactorial.

\begin{tabular}{|l|c|c|}
\hline \multicolumn{1}{|c|}{ Singularidade } & Estado de conservación (muros, cubertas) & Accesibilidade \\
\hline 5. Elemento único & 5. Bo & 5. Bordo de estrada \\
\hline $\begin{array}{l}\text { 4. Elemento singular no } \\
\text { contorno galego }\end{array}$ & 4. Regular & 4. Pista asfaltada \\
\hline $\begin{array}{l}\text { 3. Elemento singular no } \\
\text { contorno da comarca }\end{array}$ & 3. Presenza de pequenas derrubas & 3. Pista de balastro \\
\hline 2. Elemento común & 2. Grandes danos estruturais & 2. Camiño carro \\
\hline 1. Elemento moi común & 1. Só quedan as cimentacións & 1. Senda de pescadores \\
\hline $\begin{array}{c}\text { Conservación de } \\
\text { elementos mecánicos }\end{array}$ & Presenza de documentación histórica & $\begin{array}{c}\text { Contorno paisaxístico e orixinais/ } \\
\text { funcionalidade medioambiental da } \\
\text { edificación }\end{array}$ \\
\hline 5. Restaurados & 3. Identificación precisa & 5. Parque natural \\
\hline 4. Bo estado & 2. Identificación dubidosa & 4. Zona LIC/Rede Natura 2000 \\
\hline 3. Estado regular & 1. Ausente & 3. Paisaxe tradicional \\
\hline $\begin{array}{l}\text { 2. Deteriorados ou } \\
\text { desaparecidos en parte }\end{array}$ & & 2. Área urbanizada \\
\hline 1. Inexistentes & & 1. Área degradada \\
\hline
\end{tabular}

Táboa 9. Valoración de infraestruturas inventariadas 


\subsection{Selección de infraestruturas de maior representatividade}

Segundo os resultados obtidos na valoración multifactorial, establecemos, de forma ordenada por puntuación, a identificación das infraestruturas de maior representatividade (ver táboa 10).
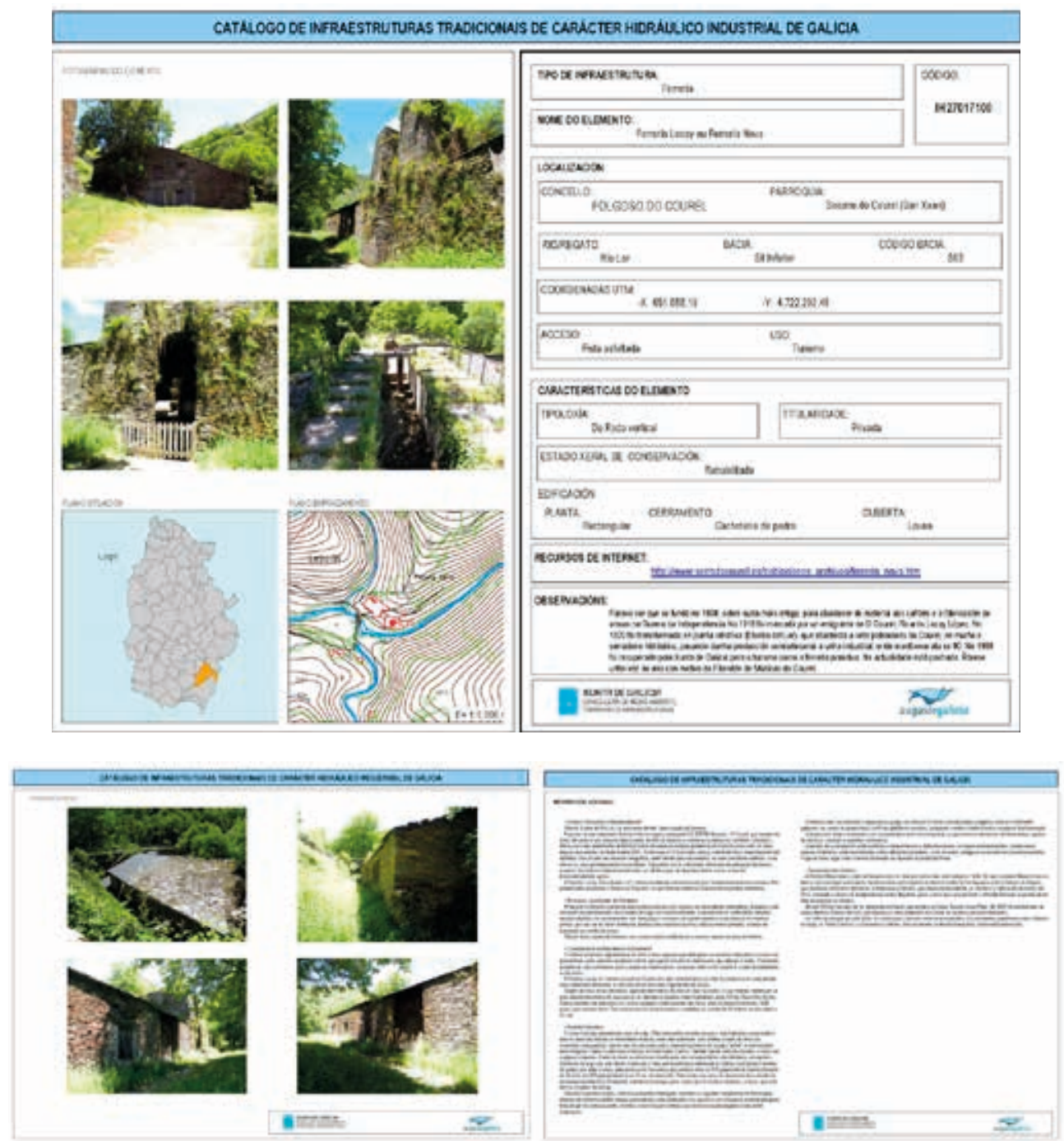

Figura 10. Exemplo de ficha do catálogo das infraestruturas máis representativas 
Esta representación consta dun total de 127 elementos e é unha mostra do patrimonio tradicional de carácter industrial presente nos ríos galegos.

\begin{tabular}{|l|c|c|c|c|c|c|c|}
\hline \multicolumn{1}{|c|}{ Provincia } & $\begin{array}{c}\text { Muínís } \\
\text { de río }\end{array}$ & $\begin{array}{c}\text { Muínos } \\
\text { de marea }\end{array}$ & Batáns & Serradoiros & Ferrarías & Pesqueiras & $\begin{array}{c}\text { Mazos/ } \\
\text { machucos }\end{array}$ \\
\hline A CORUNA & 19 & 3 & 2 & - & - & - & 1 \\
\hline LUGO & 29 & 1 & 1 & - & 2 & 1 & 5 \\
\hline OURENSE & 17 & - & - & - & 1 & - & 1 \\
\hline PONTEVEDRA & 16 & 4 & - & 1 & - & - & - \\
\hline TOTAL & $\mathbf{8 1}$ & $\mathbf{8}$ & $\mathbf{3}$ & $\mathbf{1}$ & $\mathbf{3}$ & $\mathbf{1}$ & $\mathbf{7}$ \\
\hline \multicolumn{1}{|c|}{ Provincia } & $\begin{array}{c}\text { Fábricas } \\
\text { de coiros }\end{array}$ & $\begin{array}{c}\text { Fábricas } \\
\text { de luz }\end{array}$ & $\begin{array}{c}\text { Fábricas } \\
\text { de papel }\end{array}$ & Azudes & $\begin{array}{c}\text { Minicen- } \\
\text { trais/CH }\end{array}$ & Acuedutos & Lavadoiros \\
\hline A CORUNA & 3 & 1 & 2 & 1 & 4 & 1 & 1 \\
\hline LUGO & - & - & - & - & 3 & - & - \\
\hline OURENSE & 3 & - & 2 & - & 1 & - & - \\
\hline PONTEVEDRA & - & 1 & - & - & - & - & - \\
\hline TOTAL & $\mathbf{6}$ & $\mathbf{2}$ & $\mathbf{4}$ & $\mathbf{1}$ & $\mathbf{8}$ & $\mathbf{1}$ & $\mathbf{1}$ \\
\hline
\end{tabular}

Táboa 10. Número de elementos seleccionados (127), fronte ao número total de elementos visitados (1100)

\section{POTENCIALIDADE DE POSTA EN VALOR}

Os 127 elementos de maior representatividade son sometidos a unha análise máis detallada co fin de avaliar as posibilidades e necesidades de actuación para a súa posta en valor.

Cada infraestrutura ten unhas necesidades e características específicas debido á presenza de valores elevados de calidade, singularidade e orixinalidade.

Segundo o estado de conservación da edificación, realizarase unha estimación dos investimentos que cómpre efectuar e da habilitación dos accesos.

Esta análise dos 127 elementos deu lugar a un novo catálogo que define con máis detalle o patrimonio etnográfico, cultural e arquitectónico asociado.

Para a posta en valor das distintas infraestruturas hidráulicas, diferenciaranse:

A. Infraestruturas hidráulicas de pequena dimensión. Sistematización da posta en valor. 
B. Infraestruturas hidráulicas singulares. Para rehabilitalas, será necesario realizar un estudo pormenorizado de cada infraestrutura e das súas posibilidades de uso.

C. Infraestruturas xa rehabilitadas.

Para a posta en valor das 127 infraestruturas, realizouse unha estimación económica na que se tiveron en conta os seguintes aspectos:

— Edificación: muros (limpeza/restauración), carpintaría, cuberta (limpeza/ restauración), estrutura (limpeza/restauración), chan (limpeza/restauración), instalacións (electricidade/abastecemento).

— Infraestrutura hidráulica: canle, cubo.

- Acceso e contorno.

- Difusión cultural.

\section{CONCLUSIÓN}

No presente documento, expóñense de forma resumida os traballos desenvolvidos para a realización dun «Inventario de Infraestruturas Tradicionais de Carácter Hidráulico Industrial en Galicia».

A partir de fontes documentais primeiro e de visitas a todos os concellos galegos despois (en coordinación con eles), foi posible identificar os elementos documentados e, mediante visitas de campo, aqueles que puidesen ser máis significativos en cada un deles.

Deste xeito, nunha primeira fase identificáronse case 30000 rexistros de elementos e elaborouse un catálogo inicial daqueles cuxa documentación era suficiente para incluíla nese catálogo. Nel recóllense preto de 3100 elementos.

Posteriormente, tras a visita de campo, elaborouse un catálogo que recompila os elementos máis significativos de cada concello de Galicia, recollendo neste caso preto de 1100 elementos.

Estes elementos foron estudados para finalmente obter unha relación daqueles que puidesen ter un maior interese. Desta análise resultan 127 elementos, dos cales se fixo un estudo máis detallado e para os que se valoraron cales son as accións necesarias para a súa posta en valor. 


\section{REFERENCIAS BIBLIOGRÁFICAS}

Bande Rodríguez, E. (1997): «El molino de Nuestra Señora de Beariz», en I Jornadas Nacionales sobre Molinología, Sada (A Coruña), Ediciós do Castro, 735-739. (Cadernos do Seminario de Sargadelos; 75).

BAS López, B. (1993): As construccións populares. Un tema de etnografía en Galicia, Sada (A Coruña), Ediciós do Castro. (Cadernos do Seminario de Sargadelos; 44).

BAS López, B. (1997): «Recursos y técnicas en los molinos de Galicia. Una síntesis de las tipologías», en I Jornadas Nacionales sobre Molinología, Sada (A Coruña), Ediciós do Castro, 725-734. (Cadernos do Seminario de Sargadelos; 75).

BAS López, B. (1981): «Consideracións xerais para o estudo dos muínos en Galicia», Cadernos de Estudos Galegos, tomo XXXII, CSIC-Padre Sarmiento, 96-97.

Bas López, B. (1990): «Las primeras menciones de molinos de mareas de Galicia», LLULL, 13, 43-56.

Bas López, B. (1991): Muiños de marés e de vento en Galicia, A Coruña, Fundación Pedro Barrié de la Maza.

Fernández Negral, J. (1997): «Historia y arquitectura de los molinos de un municipio costero: Cedeira (A Coruña)», en I Jornadas Nacionales sobre Molinología, Sada (A Coruña), Ediciós do Castro, 697-712. (Cadernos do Seminario de Sargadelos; 75).

Justino Fernández, J. (1991): Forxas hidráulicas, mazos ou machucos no norte galego, Sada (A Coruña), Ediciós do Castro. (Cadernos do Seminario de Sargadelos; 54).

Lema Suárez, X. M. a / R. Mouzo Lavandeira (2007): O conxunto etnográfico dos batáns e muiños do Mosquetín, na Terra de Soneira. Outros batáns, folóns ou pisóns de España e Portugal, Vimianzo, Seminario de Estudos Comarcais da Costa da Morte.

Llano Cabado, P. De (1980): O muiño de mar de A Seca, Santiago de Compostela, Colexio de Arquitectos de Galicia.

Lores Rosa, X. (1987): Os muiños, Vigo, A Nosa Terra.

López Otero, M. L. (2007): Catalogación do patrimonio etnográfico e natural na beira dos ríos de Boiro, Boiro, Cadernos Culturais, Concello de Boiro.

Pena Graña, A. (1997): «A muiñería industrial de Narón», en Primeras Jornadas Nacionales sobre Molinología, Sada (A Coruña), Ediciós do Castro, 713-723. (Cadernos do Seminario de Sargadelos; 75).

PIÑEIRO, Miguel (2008): Lampreas e pesqueiras, Vigo, Galaxia.

Soutelo VázQuez, R. / A. Varela Sabas (1997): «Los molinos del río Barbantiño», en I Jornadas Nacionales sobre Molinología, Sada (A Coruña), Ediciós do Castro, 683-696. (Cadernos do Seminario de Sargadelos; 75).

Ramiro Barros, J. (1997): Muiños nas terras de Pontevedra, Pontevedra, Deputación Provincial. 

O PATRIMONIO VENCELLADO AOS RÍOS E MANANCIAIS DE GALICIA

Xoán Nóvoa Rodríguez

Confederación Hidrográfica do Miño-Sil

DOI: 10.17075/pvpcr.2021.006 



\section{A XESTIÓN DOS RÍOS}

A auga é un elemento omnipresente en Galicia: non se pode entender a configuración da nosa xeografía nin o poboamento do territorio sen contar coa súa abondosa presenza. A auga, a través do mar e dos ríos, determina as paisaxes de Galicia ao afondar na orografía cando ten enerxía e depositar os sedimentos que transporta alí onde perde velocidade. Porén, hai zonas de Galicia sometidas a secas estacionais nas que tradicionalmente a supervivencia estaba intrinsecamente asociada á dispoñibilidade de auga para regar os cultivos.

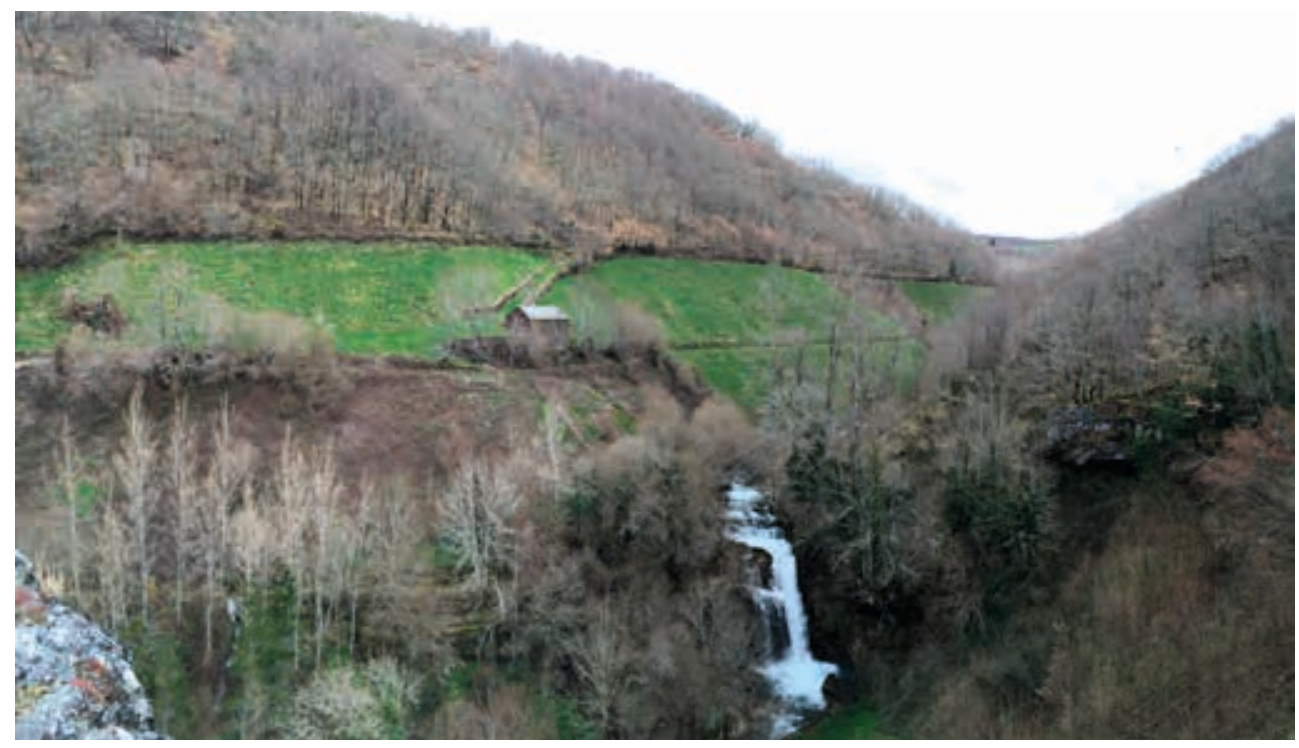

Fig. 1. Fervenza do Cachón dende o Marco do Medio Mundo. O río Lor precipítase entre prados de sega, elementos da agricultura tradicional da Serra do Courel

Pese a estar sometida durante moitos séculos á lexislación da Coroa de Castela (Partidas de Afonso X), ao longo da historia o costume desenvolveu en Galicia procedementos de seu para o mellor aproveitamento da auga e limar as posibles desavinzas entre a veciñanza, xerando técnicas e costumes que forman parte do noso patrimonio cultural.

No século XIX, coa creación dos Estados modernos, aprobáronse leis sectoriais de cara a ordenar e regular o uso deste recurso. Xa desde a Lei de augas de 1878, 
o espírito normativo ten unha forte influencia mediterránea e non sempre se adaptou axeitadamente ás necesidades de Galicia. Máis recentemente, o marco lexislativo da xestión das augas vén definido pola Lei de augas de 1985 (con modificacións parciais posteriores) e os seus regulamentos, e mais polos plans hidrolóxicos propios de cada bacía.

Algúns principios da política hidráulica que condicionan a súa aplicación son:

- A auga é un recurso natural escaso, indispensable para a vida e para o exercicio da maioría das actividades económicas; é insubstituíble e constitúe un recurso unitario, que se renova mediante o ciclo hidrolóxico.

- As augas son consideradas públicas.

- A base sobre a que se artella a administración da auga é o concepto de dominio público hidráulico, formado polas augas continentais tanto superficiais coma subterráneas renovables, os acuíferos, as augas procedentes de desalgar a auga do mar e os leitos de correntes naturais, lagos, lagoas e encoros superficiais.

- É primordial a protección do dominio público hidráulico e da súa contorna mediante o establecemento de zonas de protección e limitacións de uso.

- É prioritaria a protección das persoas e bens (entre eles, os do patrimonio) mediante limitacións a certos usos do solo para a zona de policía inundable.

Esta ordenación lexislativa colidiu coa tradición de Galicia e a convicción de que o dereito ao seu uso vén da tradición e do costume. Nesta tradición, o dereito deriva da posesión continuada do uso da auga, artellada derredor dos costumes e das asociacións de regadores que dispuñan de mecanismos internos para resolver os conflitos, preferentemente mediante acordos verbais que evitaban os longos e custosos preitos de augas da Real Audiencia de Galicia.

Por veces, os acordos quedaron escritos, como mostra un documento que chamou a atención do xuíz sevillano Nicolás Tenorio, que fora destinado a principios do século xx a Viana do Bolo. No seu libro La aldea gallega describe, pola súa singularidade, unha escritura de concordia de 1585 que se gardaba no arquivo notarial de Viana relativa ao aproveitamento dun regato entre veciños de San Martiño e de Penouta. 


\section{A BACÍA DO MIÑO-SIL E LIMIA}

A administración pública da auga baséase na unidade de xestión definida pola bacía hidrográfica. Esta vén sendo a superficie do terreo cuxa escorrega superficial flúe na súa totalidade a través de correntes, ríos e, eventualmente, lagos, cara ao mar por unha soa desembocadura, esteiro ou delta. Deste xeito, a xestión fluvial divídese en distintas unidades hidrográficas cuxa xestión corresponde aos organismos de bacía que son competencia das comunidades autónomas se son intracomunitarias e do Estado se abranguen territorios de máis dunha comunidade autónoma ou ben se se trata de ríos internacionais.

$\mathrm{Na}$ Administración do Estado, os organismos de bacía, denominados confederacións hidrográficas (C. H.), teñen unha longa tradición. Existen nove confederacións hidrográficas (Miño-Sil, Cantábrico, Douro, Texo, Guadiana, Guadalquivir, Segura, Xúcar e Ebro), sendo as últimas en se constituíren as correspondentes ao Miño-Sil e Cantábrico, creadas a partir da antiga C. H. do Norte en 2008.

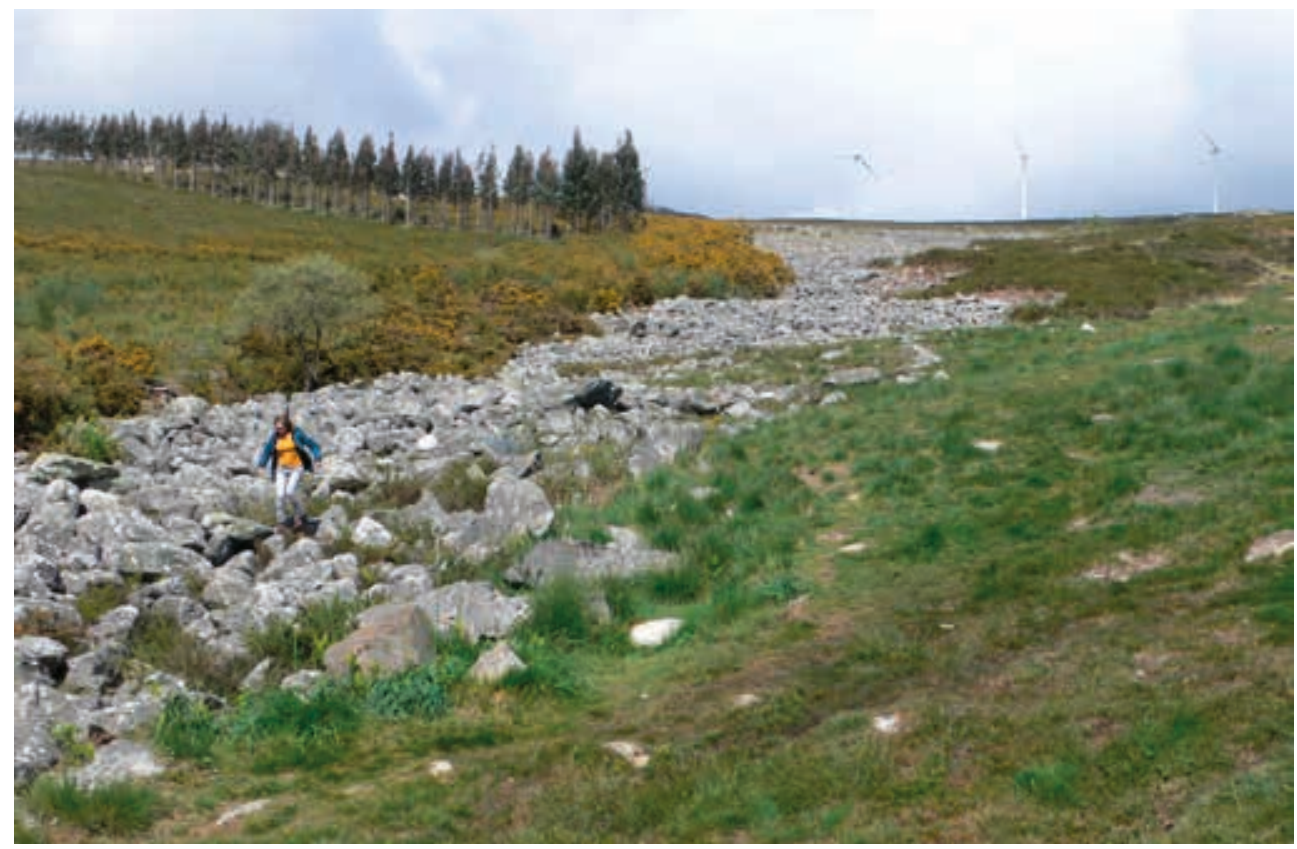

Fig. 2. O Pedregal de Irimia, unha das fontes do Miño. É un lugar máxico no que as augas flúen baixo os bloques de cuarcita, o que deu pé a abondosas lendas que «explican» a súa orixe 
A C. H. do Miño-Sil encárgase da administración hidráulica da parte española das bacías do río Miño e do río Limia, e abrangue unha superficie de 17619 km². O 77 \% do territorio está na Comunidade Autónoma de Galicia; o 22,9\%, na de Castela e León, e o 0,1 \%, no Principado de Asturias, onde nace un tributario do río Sil. É o organismo de bacía que xestiona a maior superficie de Galicia (48 \%), mais existen tamén outros tres organismos competentes en ríos galegos: Augas de Galicia (bacías interiores), C. H. do Cantábrico (bacías do Navia e o Eo) e C. H. do Douro (afluentes do Douro que nacen en Galicia).

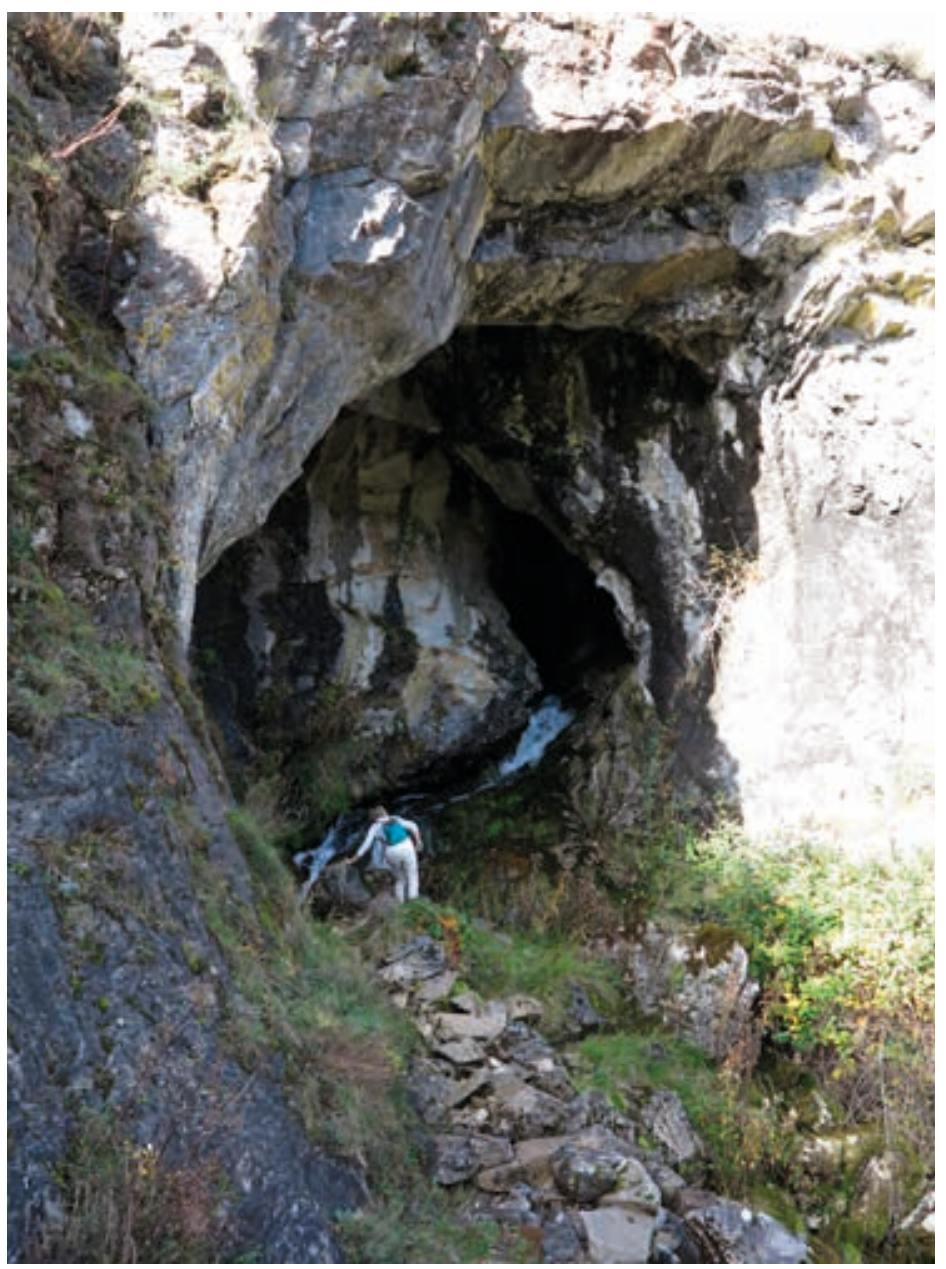

Fig. 3. Buraca das Choias, en Visuña, onde xorde unha impresionante fonte nas terras do Courel 
Trátase dun territorio no que as fontes dos ríos se localizan en montañas sobranceiras (macizo de Pena Trevinca, Os Ancares, O Courel, Macizo Central, Xistral, Suído, Xurés e oeste da Cordilleira Cantábrica) e que conta con lugares de altísimo valor natural, paisaxístico e etnográfico que cómpre protexer. Está caracterizado por unha gran dispersión de poboación (máis de 11000 núcleos) que historicamente mudou a contorna por mor da actividade agraria e o aproveitamento da auga, xerando unhas paisaxes moi singulares onde os ríos eran tratados a unha escala humana e os muíños e levadas estaban presentes desde as serras até a costa.

No século Xx, o desenvolvemento económico provocou importantes agresións do noso patrimonio natural fluvial e etnográfico, nomeadamente as obras de desecamento de zonas húmidas, a construción de presas e encoros, e a actividade mineira, actuacións que transformaron a nosa paisaxe a unha escala descoñecida.

O desecamento da lagoa de Antela comezou en 1958. Daquela era unha das zonas húmidas máis relevantes da península, pois contaba cunha superficie de 3600 ha onde se asentaba un ecosistema natural de importantísimo valor ecolóxico e unha cultura propia que non tivo tempo de se adaptar á modernidade e foi sepultada, xunto con importantes elementos patrimoniais, por unha concentración de maquinaria nunca vista en Galicia. No tempo estábase a iniciar a construción das grandes presas que crearon encoros nos que se asolagou o noso patrimonio natural e cultural, material e inmaterial, que leva décadas esmorecendo baixo as augas.

Hoxe en día, a intensa explotación hidroeléctrica dos ríos principais altéraos de xeito radical e o seu réxime natural é modificado pola presenza de innumerables presas que rompen a continuidade lonxitudinal dos leitos.

No presente artigo, centrarémonos especialmente nas características e singularidades do patrimonio cultural dos ríos e augas de Galicia nas bacías do Miño e do Limia, mais sen esquecermos o resto de Galicia alén do territorio administrativo da Confederación Hidrográfica do Miño-Sil. 


\section{A PROTECCIÓN DO PATRIMONIO CULTURAL DOS NOSOS RÍOS NA LEXISLACIÓN}

Desde sempre, a auga e os ríos desempeñaron un papel relevante nas economías tradicionais de Galicia. Os nosos ríos están inzados de construcións esparexidas e son soporte dos costumes e tradicións asentadas no imaxinario popular que configuran a identidade galega. No entanto, os ríos e a sociedade son elementos vivos onde as actividades que nun intre da historia son vitais se ven substituídas por outras ou mesmo esquecidas xunto con toda a súa cultura. Muíños, mazos, batáns, ferrarías, fábricas, pasais e poldrados son abandonados e os ríos e a natureza tenden a recuperar o seu espazo. Cómpre preguntármonos se estes elementos patrimoniais teñen algún tipo de protección que nos permita (ou obrigue) a súa conservación como elementos da cultura de outrora.

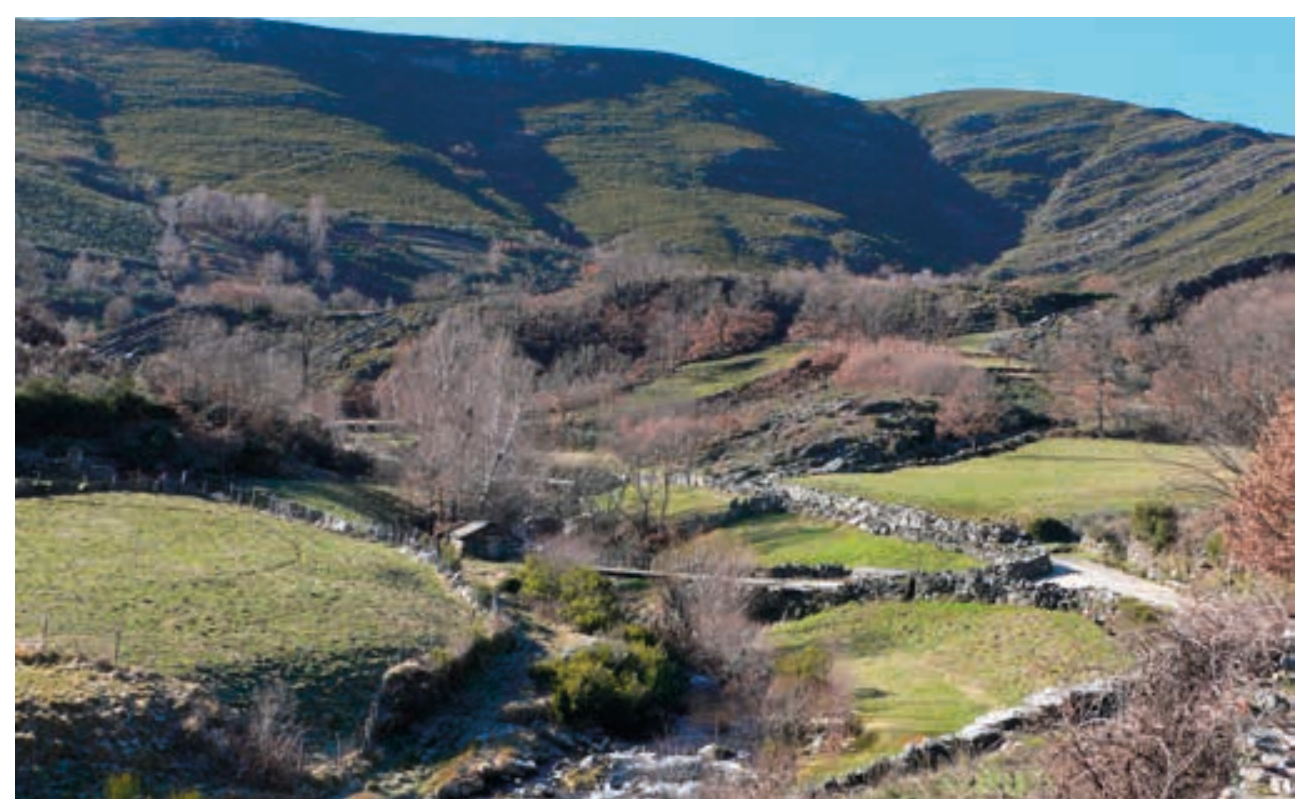

Fig. 4. Paisaxe humanizada do río Cerveira en Pradoalbar, no Macizo Central

En primeiro lugar, a Lei 5/2016, do 4 de maio, do patrimonio cultural de Galicia establece o marco xeral de protección do patrimonio, que define que está constituído por bens mobles, inmobles e o patrimonio cultural inmaterial 
que son de interese para a permanencia, recoñecemento e identidade cultural de Galicia. Existe a obriga de conservación, mantemento e custodia axeitada para evitar a destrución ou deterioración destes elementos patrimoniais que poden estar declarados de interese cultural ou catalogados.

No capítulo III, a lei recolle que o patrimonio etnolóxico está constituído por bens mobles, bens inmobles e patrimonio inmaterial, e este último suma as crenzas, expresións, coñecementos, actividades e técnicas transmitidas por tradición oral relevantes e testemuñais da cultura e formas de vida do pobo galego ao longo da historia.

Centrándonos no patrimonio etnolóxico hidráulico/fluvial, o artigo 91 indica que, entre outros, forman parte do patrimonio etnolóxico as construcións tradicionais vinculadas aos ríos e ao aproveitamento das augas como son os batáns, os muíńos de río, as ferrarías, as fontes e lavadoiros, as pontellas tradicionais e as pesqueiras ou gamoas.

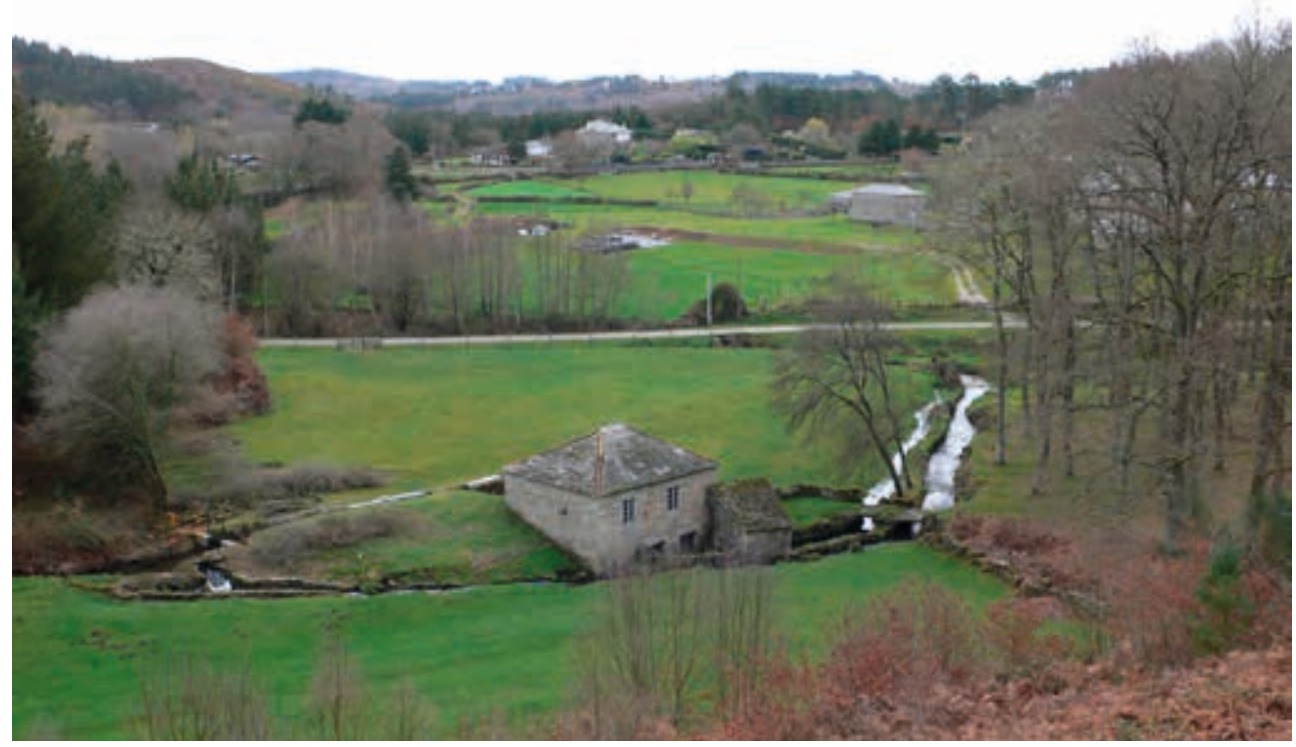

Fig. 5. Muíño de Riazón no Rego da Fonte en Ombreiro

Por outra banda, atopamos a Lei 5/2006, do 30 de xuño, para a protección, conservación e mellora dos ríos galegos. No seu artigo primeiro, declara prioridade de interese xeral da Comunidade Autónoma de Galicia a conservación do 
patrimonio natural fluvial, que inclúe a biodiversidade da flora e da fauna dos ríos galegos, así como o patrimonio etnográfico e histórico-cultural relacionado, declarándose asemade a obriga das administracións públicas galegas de garantir a súa protección, conservación e mellora.

Dentro da normativa de augas propia da C. H. do Miño-Sil, e en relación coa protección do patrimonio cultural, o vixente Plan Hidrolóxico de Bacía, aprobado en xaneiro de 2016, establece no seu artigo 48.9 que se permitirán, con carácter xeral, «as actuacións destinadas á conservación e restauración de construcións singulares do patrimonio histórico asociadas a usos tradicionais da auga, como muínos, mazos, ferrarías, entre outras construcións de gran valor etnográfico e testemuñas da tradición sempre que se manteña o seu uso tradicional e non permitindo, en ningún caso, un cambio de uso salvo o acondicionamento "museístico"».

\section{O PATRIMONIO HIDRÁULICO}

O patrimonio hidráulico está formado por un conxunto de elementos englobados en distintas categorías que teñen en común a auga con distintos aproveitamentos ou simboloxía. Componse do patrimonio cultural do que forman parte as montañas e vales fluviais, elementos definitorios da paisaxe por excelencia que xeran ao longo da historia unha cultura propia, de condicións extremas de vida. Outra categoría patrimonial aceptada tradicionalmente está constituída polo patrimonio arquitectónico e arqueolóxico, do que forman parte pontes, canles e restos arqueolóxicos, que dispoñen das figuras de protección máis antigas que se estableceron até o de agora.

Porén, imos prestar especial atención ao patrimonio etnográfico (etnolóxico, segundo a definición da Lei do patrimonio cultural de Galicia) e ao patrimonio inmaterial asociado aos nosos ríos e fontes, menos recoñecidos historicamente malia seren fundamentais para coñecer a nosa historia e tradición.

\subsection{O patrimonio etnolóxico}

Os elementos do patrimonio etnolóxico son testemuñas dun tempo pasado e manifestan un xeito de vivir e unha humanización da paisaxe que, co tempo, foron substituídos por outras actividades ou mesmo desapareceron de súpeto, sen 
nos decatarmos, como resultado da perda da súa razón de ser, do abandono, da emigración e do despoboamento.

Aínda así, existen moitas categorías con exemplos salientables que puideron chegar a nós. Imos dar un repaso aos máis característicos da nosa paisaxe, tan humanizada e rica en solucións imaxinativas ante as demandas de cada bisbarra.

\section{As fontes}

Froito da nosa climatoloxía xenerosa, en Galicia abundan os mananciais, o que posibilita atopar fontes en calquera lugar da nosa xeografía, moitas das cales contan cun grande arraigamento cultural na nosa comunidade.

As máis tradicionais adoitan estar en lugares céntricos das aldeas ou vilas e son espazos de encontro e reunión social como complemento da súa función básica para abastecer e dar de beber ao gando. Constan dunha canalización desde o manancial e dun paramento vertical do que sae un cano que deita a auga nunha pía.

As fontes reciben distintos nomes en función das propiedades que se lles supoñen (boa, fría, milagreira, santa) ou das súas características físicas (fontenla, fontiña, fontalón...).

De sempre, as fontes eran lugares de confluencia e reunión da comunidade. $\mathrm{O}$ valor simbólico que teñen para os galegos maniféstase nas frecuentes lendas transmitidas pola sabedoría popular por veces herdeiras de crenzas pagás que se funden na historia (Fig. 6).

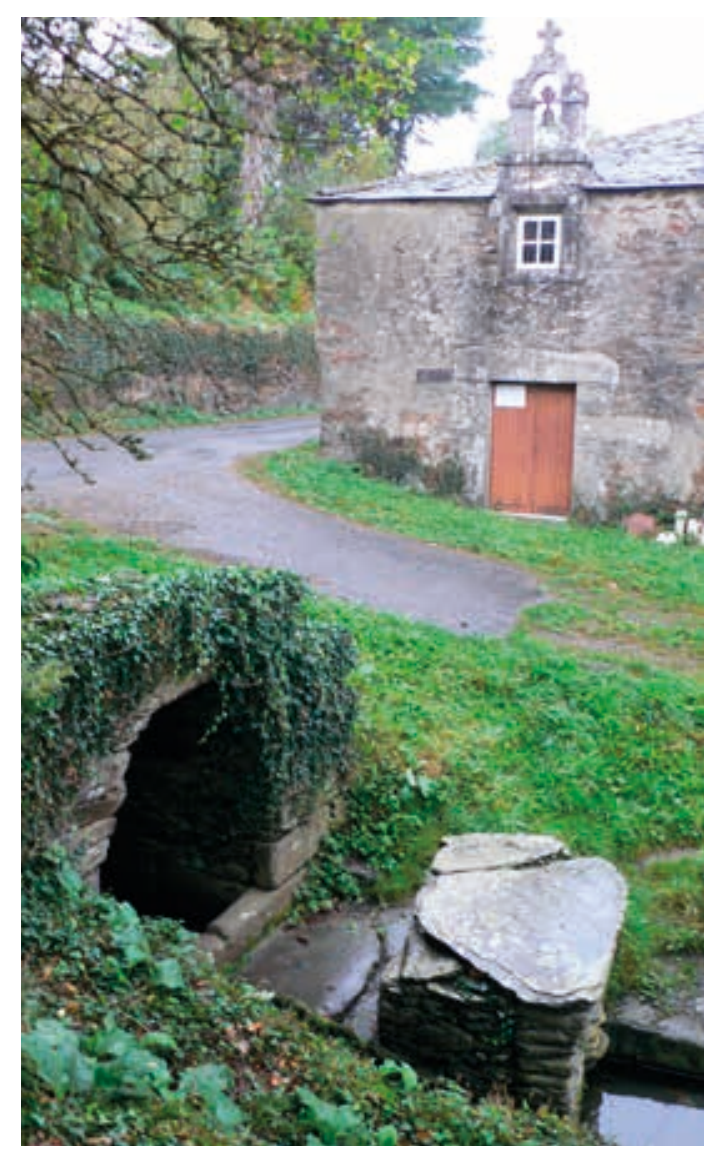

Fig. 6. Fonte de Couto de A, onde mora unha fada baixo a forma dunha troita 
Máis recentemente, no século XX, aparecen as fontes (e lavadoiros) promovidos polos emigrantes (en especial, de América) como intento por parte dos que partiron de mellorar as condicións de vida das comunidades de orixe. Temos exemplos espallados ao longo de toda Galicia acompañados, decotío, de lavadoiros públicos.

\section{As regas}

Foron unha importante fonte de conflitos no campo de Galicia, e a súa demanda e técnicas foron evolucionando en función da transformación que se deu no sistema agrícola entre o século XVIII e mediados do século XX. Neste período, ten lugar un incremento progresivo da superficie dedicada á rega de prados e cultivos forraxeiros como consecuencia da especialización gandeira do sistema de produción.

Aínda que existían sistemas de rego directo, as técnicas máis singulares danse nos sistemas de comunidades de regadores, agrupacións precisas para socializar os traballos e establecer normas de distribución. Hai variados sistemas de derivación, almacenaxe, repartición e control da auga de rego, sendo habitual que en cada parroquia existise unha regulación propia que repartía os traballos comunais, establecía quendas de rega e resolvía os conflitos.

Os distintos sistemas tradicionais de rega foron documentados xeograficamente por Abel Bouhier, grande estudoso do sistema agrario tradicional galego, na súa tese presentada en 1977, tras 17 anos de traballos. Ao seu parecer, o noso sistema agrario baseábase nun gran gasto de traballo humano regulado pola emigración temporal ou definitiva, e con aplicación de técnicas sinxelas, enxeñosas e coherentes, entre as que destacaban o sistema de regas singulares que describe en detalle nos seus traballos. Bouhier salienta, por imaxinativas, as técnicas de irrigación empregadas nas montañas orientais e do extremo sueste, unhas zonas con importantes secas estacionais que requirían da colectivización do traballo para conducir a auga. Nestas áreas son comúns levadas de máis de $10 \mathrm{~km}$ de lonxitude entre a toma e as zonas de rega, ocasionalmente con muínos intermedios e regulamentadísimos sistemas para tornar as augas nas zonas de consumo. (Fig. 7)

Entre as moitas tecnoloxías propias adaptadas ao territorio, existían unhas de gran singularidade: as «pozas de aire», frecuentes na Baixa Limia. Cando os caudais dispoñibles non chegaban ás zonas de rega, facíanse depósitos cun sistema de apertura/ peche baseado no nivel da auga na charca e o principio dos vasos comunicantes, de xeito que os dispositivos se abrían cando estaban cheos e pechábanse ao baleirarse. 


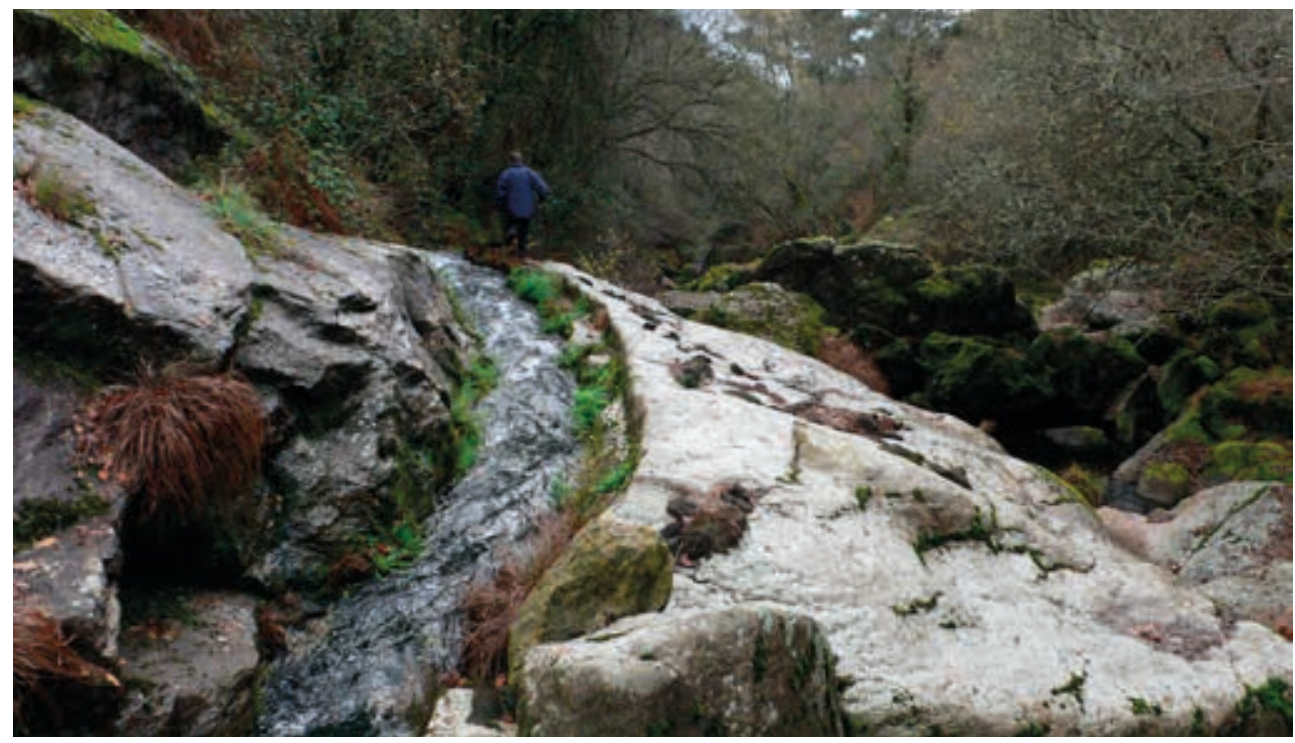

Fig. 7. Levada do Castro-Valeixe que conduce a auga dende o río Deva aos agros por unha canle de case 6 quilómetros de lonxitude e serve no seu percorrido a varios muínos

Pese á inadaptación frecuente dos nosos sistemas de produción agrícola ás necesidades de eficiencia produtiva, estes sistemas tradicionais de rega aínda teñen unha fonda tradición en comunidades nas que non se rompeu a transmisión dos coñecementos polo abandono do rural.

\section{Os muínos}

Os muíños foron un dos elementos máis característicos do mundo rural e dos máis definitorios da paisaxe fluvial galega. Aínda que o mecanismo fose coñecido desde a época romana, a tecnoloxía dos muínos hidráulicos difundiuse en Galicia a partir do século XI, posiblemente por influencia dos mosteiros.

Porén, o seu gran crecemento dáse a partir do século XVIII como consecuencia da xeneralización do cultivo do millo, de xeito que a finais do século, Lucas Labrada indicaba que había máis de 8000 muíños en Galicia.

Dispoñemos de abundantes publicacións que describen a súa tecnoloxía. A maquinaria precisa da forza da auga que fai xirar un eixe (vertical nos máis dos casos ou horizontal nas aceas e noras) que, pola súa vez, vira unha das moas, o que permite a moenda. 
Os muíños hidráulicos presentan unha gran variedade de tipoloxías en Galicia. Cando o caudal e o desnivel son escasos, cómpre crear un salto aproveitable e mesmo acumular auga para regular e incrementar o caudal. Para conseguilo, utilízase unha levada até un resalto natural ou artificial que permita un mellor aproveitamento. (Fig. 8)

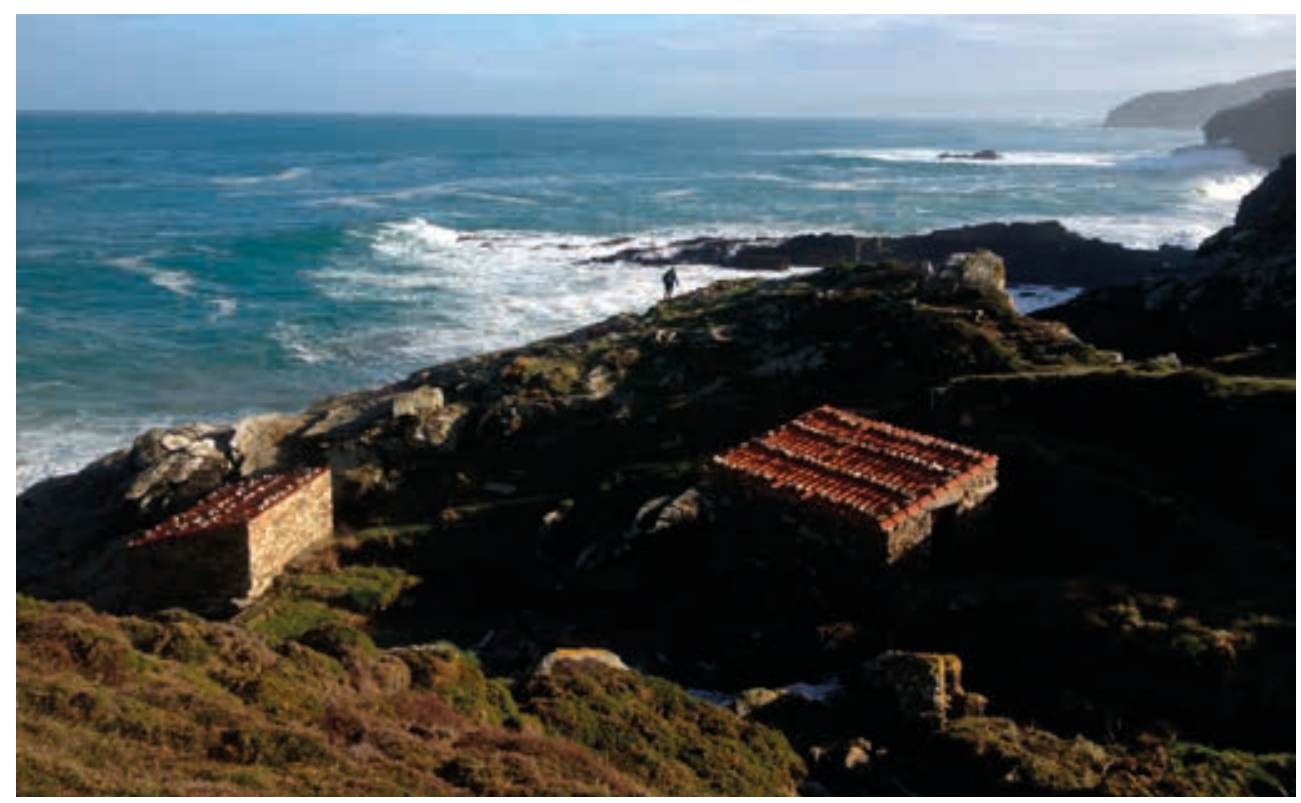

Fig. 8. Muíńos encadeados en Ardeleiro que aproveitan a auga da reducida bacía do Rego dos Muíños

Se a corrente é importante, o mecanismo acciónase con saltos menores, posibilitando un funcionamento continuo ao longo de todo o ano e multiplicando o número de moas. Nestes casos, faise necesaria a construción de presas e edificios sólidos que resistan as enchentes, o que motivou que, en determinadas zonas propicias coma a Terra Chá, constituísen auténticas industrias. (Fig. 9)

En canto á propiedade, existían muiños de herdeiros, en xeral de dimensións reducidas, construídos por unha o máis familias e con dereitos e obrigas colectivas de mantemento, e muiños de maquía, onde o servizo se facía a cambio dunha parte da moenda (maquía). Neste último caso, eran construcións de maior tamaño, en correntes con caudal abundante e con necesidade de achegar considerables recursos que excedían as posibilidades das economías de subsistencia. 


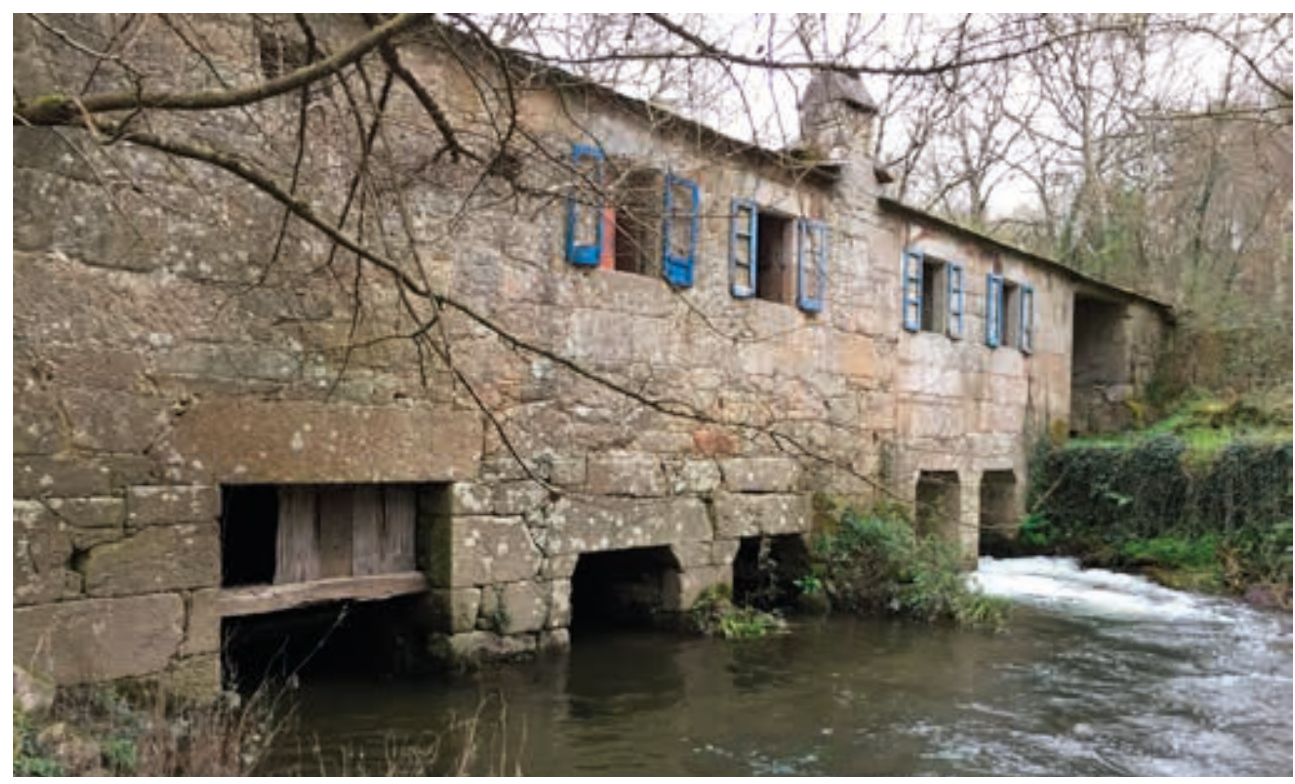

Fig. 9. Muíño de Paz en Moscán, impresionante edificio no caudaloso río Neira

Os muíños constituían un centro de reunión social no que a xente se entretiña mentres agardaba a quenda, o que deu pé ao desenvolvemento dunha cultura propia da que as muiñeiras son o mellor expoñente que puido chegar a nós.

A partir da década de 1950, produciuse un continuo abandono dos muínos hidráulicos ao seren substituídos por muíños eléctricos, «molineras», máis eficaces. A perda da súa importancia na economía rural levou consigo a desaparición do seu valor social. Aínda que as persoas galegas non sempre somos respectuosas coa tradición e o seu significado, na actualidade moitos dos muíños dispoñen de concesión de auga e, malia seren escasos, hainos con actividade «industrial».

\section{Os pasos, pasais, portos e pontellas dos camiños}

Os camiños tradicionais, os seus valados e as obras de paso tradicionais para salvar as correntes de auga deberían contar cunha protección especial en toda Galicia. Estas construcións, fundamentais para a actividade cotiá, crean unha rede que artella e humaniza o territorio facendo posible as distintas actividades económicas e sociais. Constitúen un catalogo de solucións que a enxeñaría e a tecnoloxía tradicionais aplican para salvar as dificultades das distintas xeografías, desde as 
serras ás chairas, empregando as litoloxías dispoñibles. A importancia da vía para a comunidade tamén condiciona a solución adoptada.

Destacaremos nesta lembranza as obras tradicionais sinxelas, excluíndo as pontes, cuxa execución require unha tecnoloxía evolucionada. As solucións van desde as máis simples, sen apenas construción, que se utilizan para ríos importantes (neste caso non é doado para a tecnoloxía tradicional atopar solucións) até outras máis evolucionadas que utilizan as pedras dispoñibles na contorna.

A solución máis sinxela é o vao ou porto, utilizado para pasar ríos con pouca fondura e que como única construción (mais non sempre presente) podería ter un lousado no leito. Os portos serían tamén a denominación das construcións auxiliares das barcas de paso, documentadas desde antigo e que se utilizaron en moitos ríos até ben entrado o século XX. Había barcas con arames que unían as beiras, pero o máis común eran as de barqueiro que cobraba o seu servizo e que, en función do tamaño, podían cruzar persoas e mesmo carros cos animais de tiro e mais a carga.

Se cadra o paso de obra máis sinxela é o pasal ou poldra (Fig. 10), empregado en ríos importantes con frecuentes enchentes por chuvias torrenciais e que ofrece unha resistencia reducida á corrente. Trátase de pezas de pedra, usualmente prismática, que se chantan directamente no leito a distancia de paso humano.

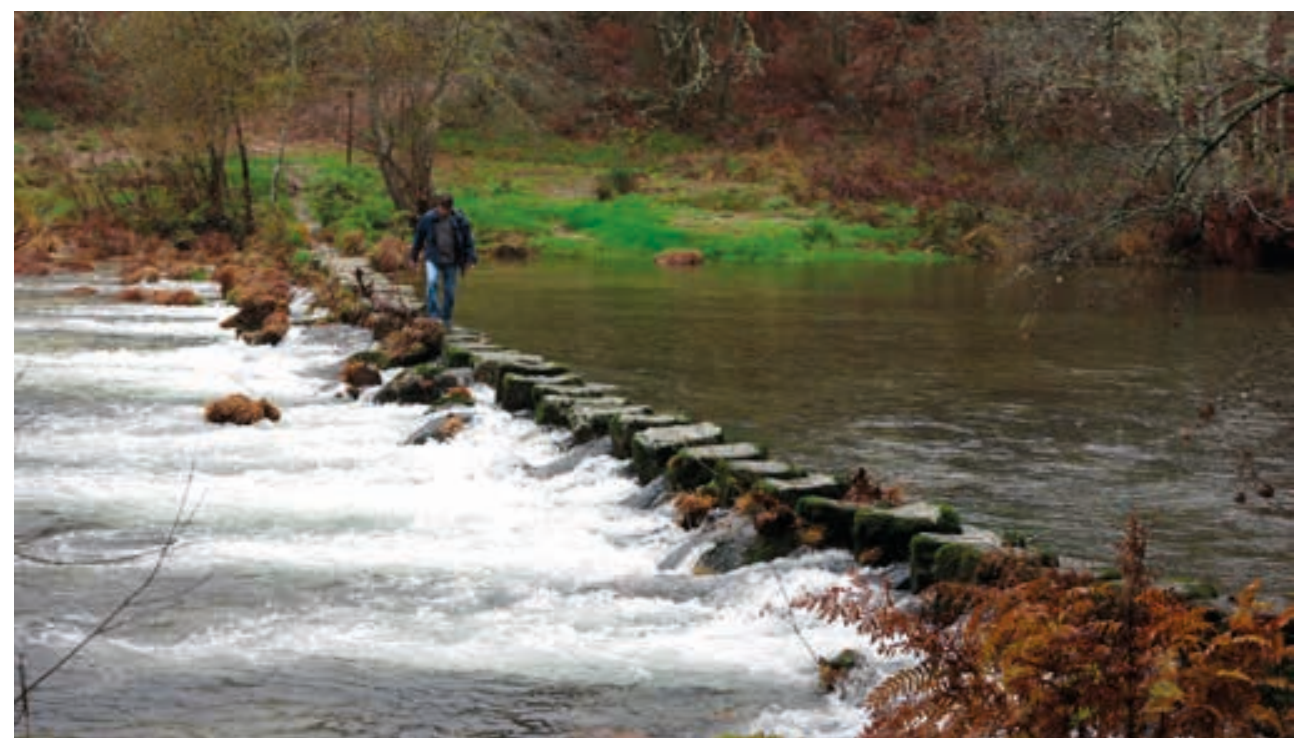

Fig. 10. Pasal do Muíno de Tatín no río Tea 
Finalmente, teriamos os elementos tradicionais que precisan a técnica máis evolucionada, as pontellas (Fig. 11), formadas pola cimentación, pías ou cepas e calzadas (se ben as máis sinxelas poden non ter pías), que admiten distintos materiais: gran, lousa, xisto e mesmo madeira. Son estruturas sinxelas, rústicas ou con acabado de cantaría, que poden ter varios tramos e con zona de paso de lousas de pedra, madeira ou unha combinación dos elementos dispoñibles. Desde as estruturas máis elementais formadas por troncos recubertos de terra ou laxes até linteis de pedra que forman falsos arcos, existen multitude de solucións para as pontellas ao longo dos ríos e corredoiras de Galicia.

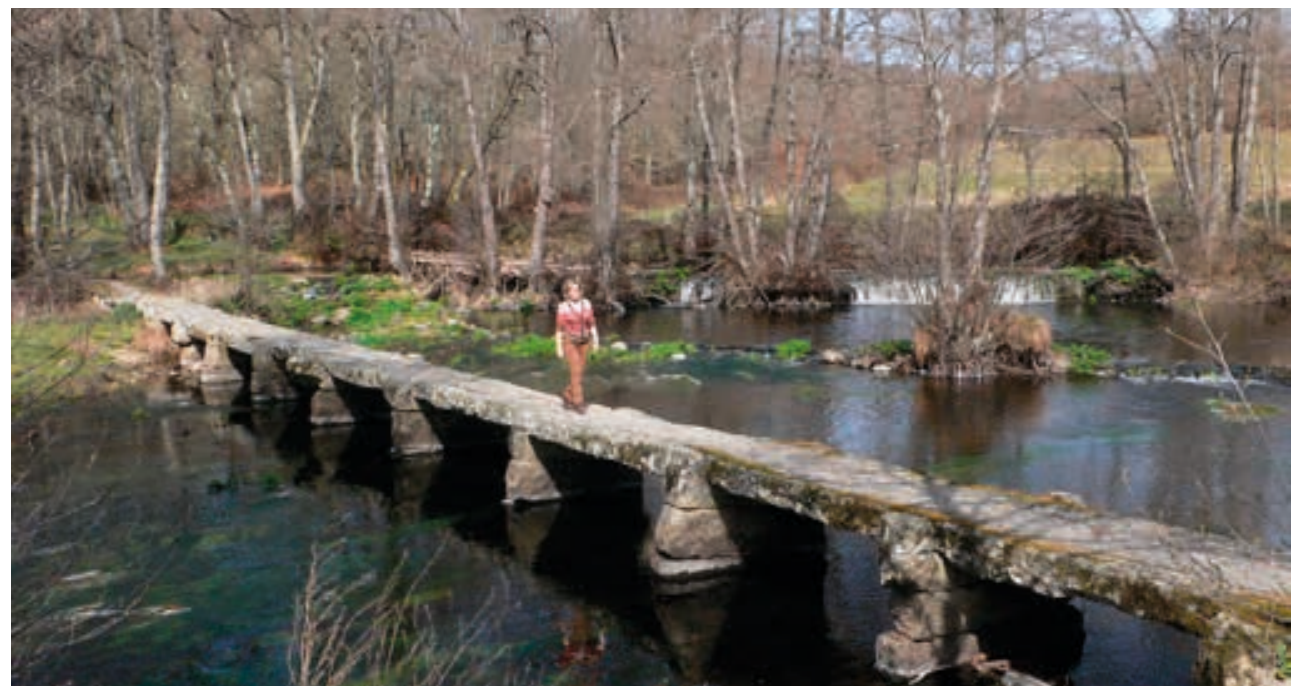

Fig. 11. Pontella sobre o río Arnoia en Xunqueira de Ambía

\section{As pesqueiras e os caneiros}

Ao ser a pesca fluvial un recurso complementario en toda Galicia, hai dúas técnicas de pesca que adquiriron unha especial relevancia pola transcendencia económica: os caneiros da Terra Chá e Portomarín (Miño e principais tributarios) e as pesqueiras do Baixo Miño.

Os caneiros eran estruturas de pedra que se chantaban no leito dos ríos e se utilizaban para a pesca da anguía desde setembro até que chegasen as primeiras enchentes do inverno (Fig. 12). Estaban formados por espigas converxentes de pedra, a pía (onde se asentaba unha caseta de pedra ou madeira) e as bocas (onde 
se colocaban os aparellos). Aparecen documentados no século XVIII no Catastro de Ensenada, pero pode que existisen antes. En relación coa súa propiedade, o máis habitual era que pertencesen a familias, se ben algunhas pesqueiras permaneceron aforadas até a abolición dos foros en 1932.

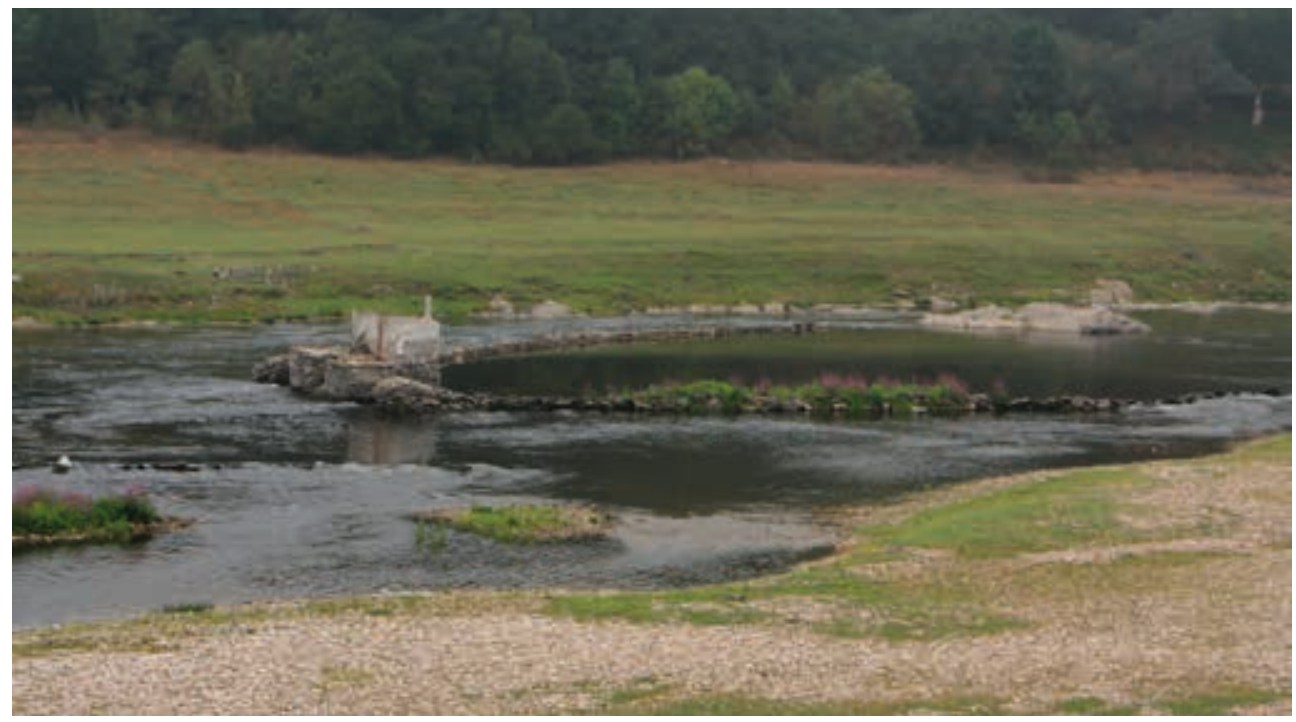

Fig. 12. O encoro de Belesar mergullou unha parte importante do patrimonio cultural e etnográfico vinculado ao río Miño. Coa baixada estival do nivel, na cola do encoro agroman temporalmente os restos de antigos caneiros entre Francos e San Mamede

As outras estruturas de pesca (máis estudadas) son as pesqueiras ou piscos do Baixo Miño, utilizadas para a captura da lamprea de febreiro a maio. Estaban formadas por elementos de pedra parcialmente transversais á corrente (poios e rabo) e pola rede (buitón). As pesqueiras aparecen citadas en textos do século XI co nome de piscarias e, como curiosidade, as situadas en Arbo eran propiedade do mosteiro de Melón. Como mostra da súa importancia económica, a principios do século XX estaban censadas máis de 700 pesqueiras en $25 \mathrm{~km}$ de río entre Crecente e Arbo.

O final desta actividade económica veu derivado da entrada en vigor da Lei do 20 de febreiro de 1942, pola que se regulaba o fomento e conservación da pesca fluvial. No seu artigo 21 prohibíase a construción de muros, paredes, estacadas, palizadas, tabiques, caneiros, canaveiras ou pesqueiros que servisen como medio 
de pesca, e establecíase que se debían destruír os existentes sen que se puidese alegar dereito ningún sobre eles, dado o seu «carácter abusivo».

\subsection{O patrimonio inmaterial}

Á parte dos bens mobles e inmobles que forman parte do patrimonio cultural, non é menos relevante e sobranceiro o patrimonio cultural inmaterial de Galicia vinculado ás augas, constituído por usos, coñecementos, expresións orais, a hidronimia e a toponimia, as danzas e músicas xeradas na contorna dos muínos, usos sociais, rituais e técnicas tradicionais.

O patrimonio cultural inmaterial é unha das manifestacións máis senlleiras da singularidade cultural da nosa terra e é consecuencia da interacción dos nosos devanceiros coa natureza e outras culturas a través da historia. Asemade, en Galicia son comúns topónimos vinculados ás augas (fonte, fontela, fontella, fontalón...) e os seus usos (levada, torneiros, mazo, barco...), e mesmo os hidrónimos/topónimos expresan a importancia do río ou os temores que xera (Riobó/Ríomao).

Con todo, se algo caracteriza a nosa tradición popular é a preservación de crenzas, mitos e lendas asociadas ás augas. En palabras de Fermín Bouza-Brey, "apenas hay corriente sin encanto en nuestra tierra». E é que o culto á auga en Galicia ten as súas raíces na Prehistoria, se cadra derivado do compoñente misterioso da auga que abrolla da terra e se está a renovar seguido. Tense constancia da abondosa mitoloxía das augas no substrato prerromano, en paralelo e relación con outras culturas da Europa atlántica.

Malia que moitos destes seres mitolóxicos estaban asociados a ninfas romanas (deidades moradoras de fontes e mananciais), hai constancia dalgúns nomes, entre os que destaca Navia, sobranceira deusa das augas de culto xeneralizado en Galicia que deixou a pegada na hidronimia (Navia, Navea ou Neiva). Son escasas as inscricións de divindades indíxenas de fontes, aínda que coñecemos que Edovius era o deus indíxena das máxicas fontes de augas termais de Caldas de Reis.

É lóxico pensar que o cristianismo tentou pór fin a estas supersticións e con resultados pouco efectivos, como pon de manifesto no século VI a inquedanza de San Martiño de Dumio, personaxe sobranceiro da nosa historia. Preocupado pola preservación dos ritos pagáns, condena, entre outros, o culto ás fontes na súa obra De correctione rusticorum. 
Ende ben, os mouros e as mouras, seres imaxinarios de Galicia que entran na categoría sobrenatural, conseguiron chegar a nós. Trátase de seres singulares que non teñen encaixe nin na familia das divindades nin na dos demos, por moitos intentos infrutuosos do cristianismo por asocialos co diaño. Os mouros e as mouras moran en lugares nos que os humanos non poden vivir, como dentro das pedras ou por baixo da auga. Tamén hai moitos que ocupan as nosas fontes e pozas, que nese caso collen o nome dos seres que habitan nelas. É frecuente atopármonos coa fonte da Moura, a poza da Moura ou derivacións como Aureana, Laureana ou Ana, que se vinculan coa presenza de ouro ou tesouros.

Existen outros seres das augas de Galicia máis ou menos emparentados cos mouros como xacios, lavandeiras, xigantes, homes peixe ou habitantes de cidades asolagadas que amplían a riqueza do noso «panteón» de seres sobrenaturais. Merecen especial mención os xacios do Miño, unha raza de seres mitolóxicos coa metade superior con forma humana e a inferior de peixe que habitaban (en pasado) no Miño á altura de Chantada/Pantón en varias pozas e ao pé do Castro de Marce. Digo «habitaban» porque, coa construción dos encoros dos Peares e Belesar, tiveron que abandonar a súa morada, deixando esquecidos para sempre os tesouros que agochaban xunto coa súa memoria.

No entanto, ademais de fontes máxicas, tamén temos fontes santas (por veces existe unha liña tenue que as separa) con advocación habitual a santas ou virxes, o que manifesta a evolución de elementos precristiáns relacionados con divindades femininas. Neste caso son consideradas milagreiras e son obxecto de devoción, en contraste coas fontes máxicas, frecuentemente asociadas a encantamentos. As fontes de Santa Mariña de Augas Santas (Fig. 13),

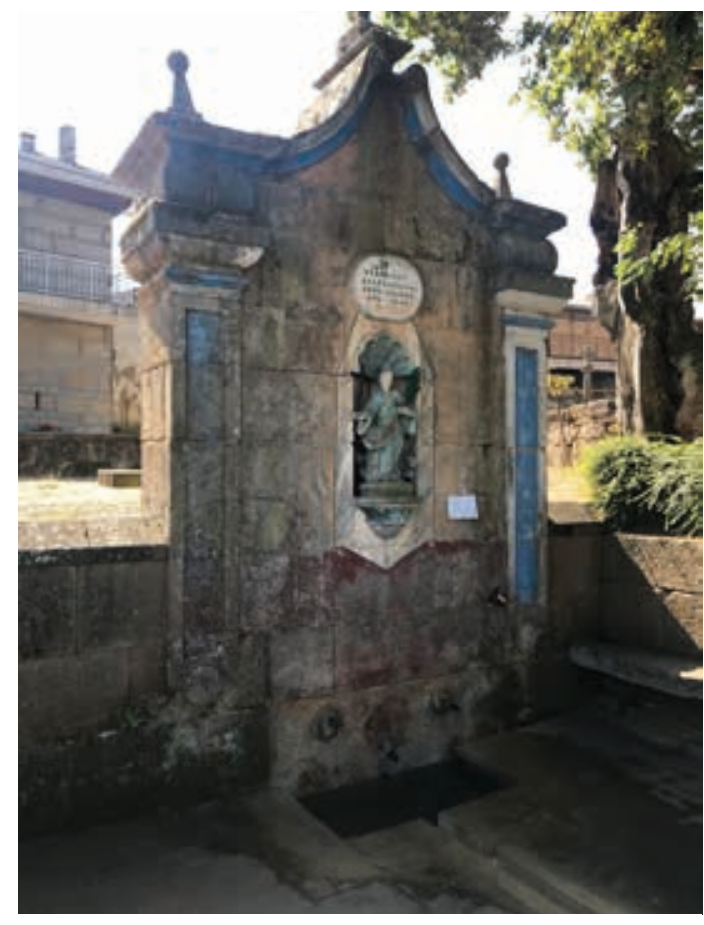

Fig. 13. Fonte de Santa Mariña de Augas Santas en Allariz 
Santa Xusta en Moraña, Santo André de Teixido, Santo Alberte de Guitiriz, San Xil de Casaio e a fonte da Milagrosa Santa Cruz de Aranga son só unha mostra da tradición destas fontes espalladas por toda Galicia onde se mergulla o imaxinario colectivo do pobo galego. E, para amosar unha vez máis a riqueza cultural do noso país, en Narón hai dúas fontes: a de Santa Margarida do Val, con propiedades para mellorar a fertilidade, e a fonte da Moura en Esperón, con propiedades anticonceptivas.

Non quero rematar sen lembrar unha serpe que mora nunha das poucas lagoas naturais que temos en Galicia, na parroquia da Ponte nas serras de Pena Trevinca (Fig. 14). Disque nesta lagoa glaciar vive unha gran serpe que nas noites de lúa chea se transforma nunha fermosa moza presa dun encantamento que agarda a chegada dun mozo que a libere. Coma sempre nestes casos, hai moitas versións sobre intentos fracasados, pero hai quen di que un mozo da Ponte rompeu o encantamento. Segundo a lenda citada por Afonso Vázquez-Monxardín, toda persoa que beba da súa auga morrerá e, se te metes nela, non poderás saír. Sexa como for, esta lenda serve para ilustrar o marabilloso patrimonio inmaterial e é motivo para achegármonos á singular lagoa glaciar situada nos confíns das terras orientais de Galicia.

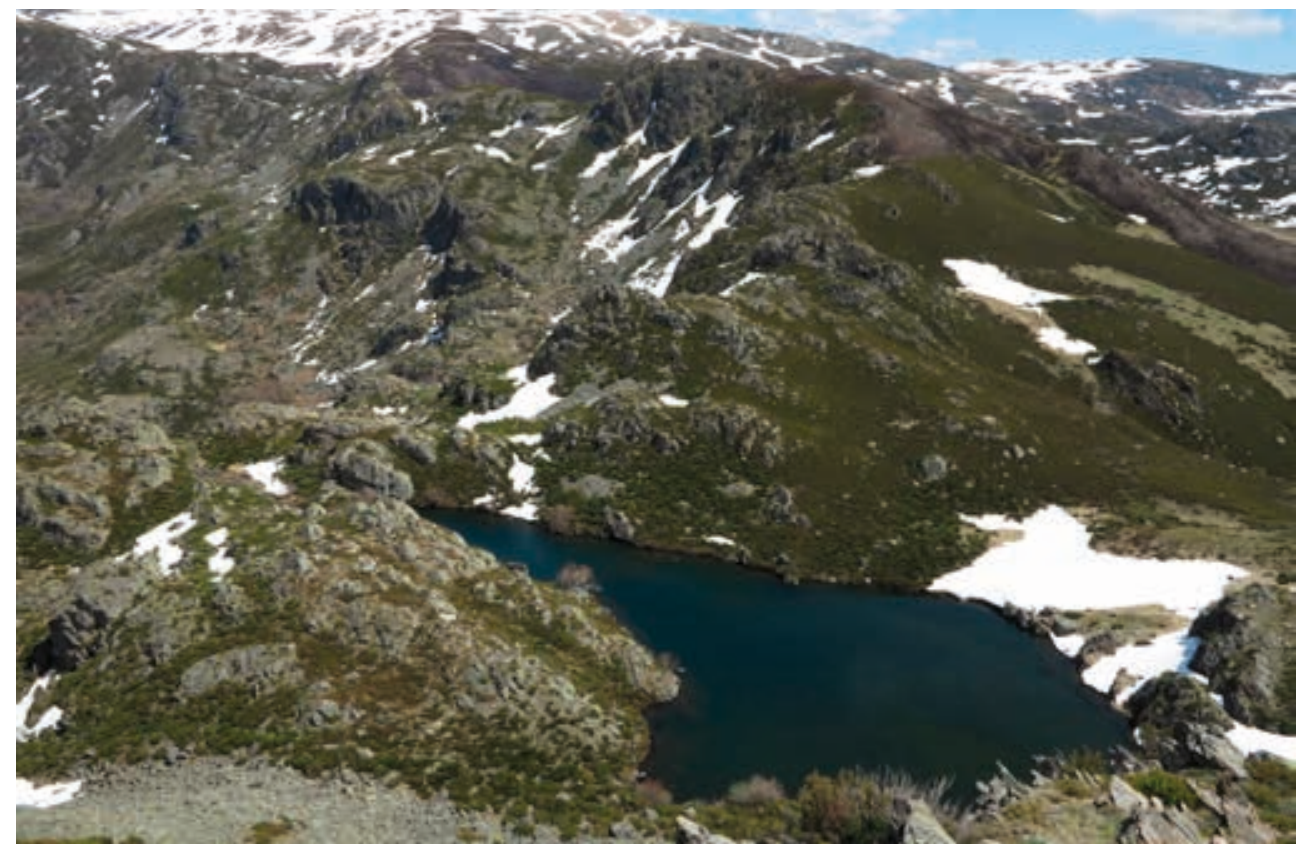

Fig. 14. Lagoa «encantada» da Serpe no macizo de Pena Trevinca 


\section{REFERENCIAS BIBLIOGRÁFICAS}

Bouza-Brey, Fermín (2019): La mitología del agua en el noroeste hispánico. Discurso lido o día 27 de xullo de 1941 no acto da súa recepción, polo ilustrísimo señor don Fermín Bouza-Brey Trillo, A Coruña, Real Academia Galega.

LuCAS Labrada, José (1971 [1804]): Descripción económica del reino de Galicia, Vigo, Editorial Galaxia.

Jové Clols, Rosario (1981): Sermón contra las supersticiones rurales, Barcelona, El Albir. (Tradución moderna de De correctione rusticorum de San Martiño de Braga).

Tenorio, Nicolás (2008): «La aldea gallega. Estudio de derecho consuetudinario y economía popular». [Introdución de Carlos García Martínez]. Galegos 1, 149-188.

VÁzquez-Monxardín Fernández, Afonso (1994): «102 lendas e noticias lendarias», Boletín Auriense, Ourense, tomo 24, 287-336. 


\section{UN RÍO QUE NACE FRADE E MORRE BISPO OU NACE BISPO E MORRE FRADE. APUNTAMENTOS SOBRE O PATRIMONIO CULTURAL HIDRAULICO GALEGO}

Francisco Alonso Toucido Grupo de investigación Síncrisis (USC) Estela Arqueoloxía e Patrimonio S. L. 

No país dos mil ríos, o ser humano condicionou en gran medida, nun momento máis ou menos próximo a nós, a paisaxe que xeralmente entendemos como natural. Os ríos, dada a súa importancia no tocante aos recursos alimentarios, enerxéticos, industriais e de transporte, non son alleos a este feito. Un bo exemplo disto é o condicionamento antrópico en moitos ríos galegos nos que o último punto que acada a auga salgada do mar, na súa desembocadura, é algún tipo de estrutura realizada polo ser humano, como unha represa de pesca, uns pasos ou, no río Lérez, o encoro de captación de auga de Bora.

O uso continuo dos ríos por parte da sociedade ao longo da historia, así como as peculiaridades do seu sistema de poboamento, do seu sistema agrario tradicional e do seu devir histórico, permítenos contar con ríos cheos de patrimonio, tanxible e intanxible.

Se consultamos un visor de planificación urbanística de Galicia como o Plan Básico Autonómico, na súa capa de ríos podemos observar a alta densidade de cursos fluviais que existen, ademais das súas áreas de protección desde a perspectiva da xestión da auga. No entanto, estas áreas agochan tamén un patrimonio rico e singular que esmorece.

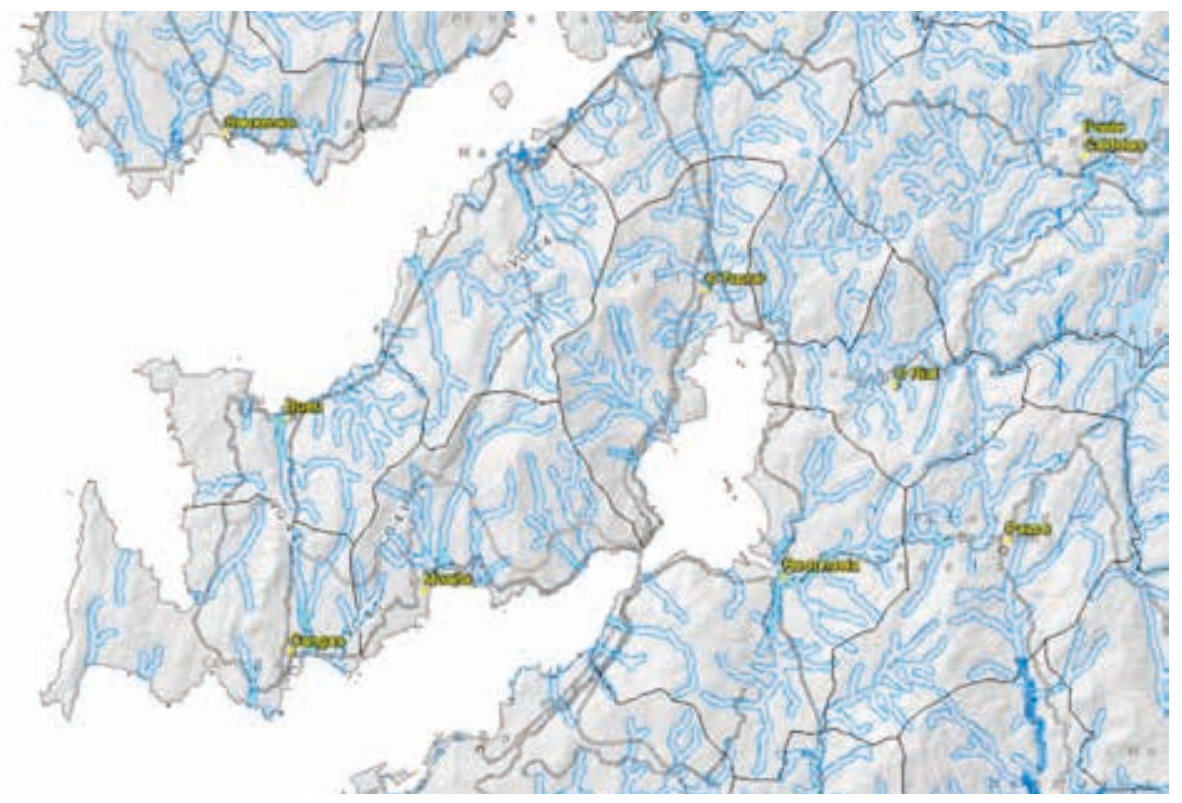

Áreas de protección dos cursos fluviais do Morrazo. Fonte: PBA Xunta de Galicia 
Os ríos son custodios de obras de auténtica enxeñaría popular. Os construtores de pontes tradicionais, canles de rego, levadas e muíños eran auténticos enxeñeiros sen titulación. Poñamos por caso un dos patrimonios hidráulicos máis recorrentes: os muíños. Adoitamos contemplar cada un deles sen ter en conta o seu contexto e as difíciles condicións da contorna nas que foron edificados. Non somos conscientes dos seus sistemas de captación, xa que os muíños acostuman levar a auga desde moitos metros río arriba cunha correcta inclinación e estas levadas aliméntanse de presas necesarias para desviar a auga e devolverlla máis adiante ao río ou ao seguinte muíño a través dos infernos.

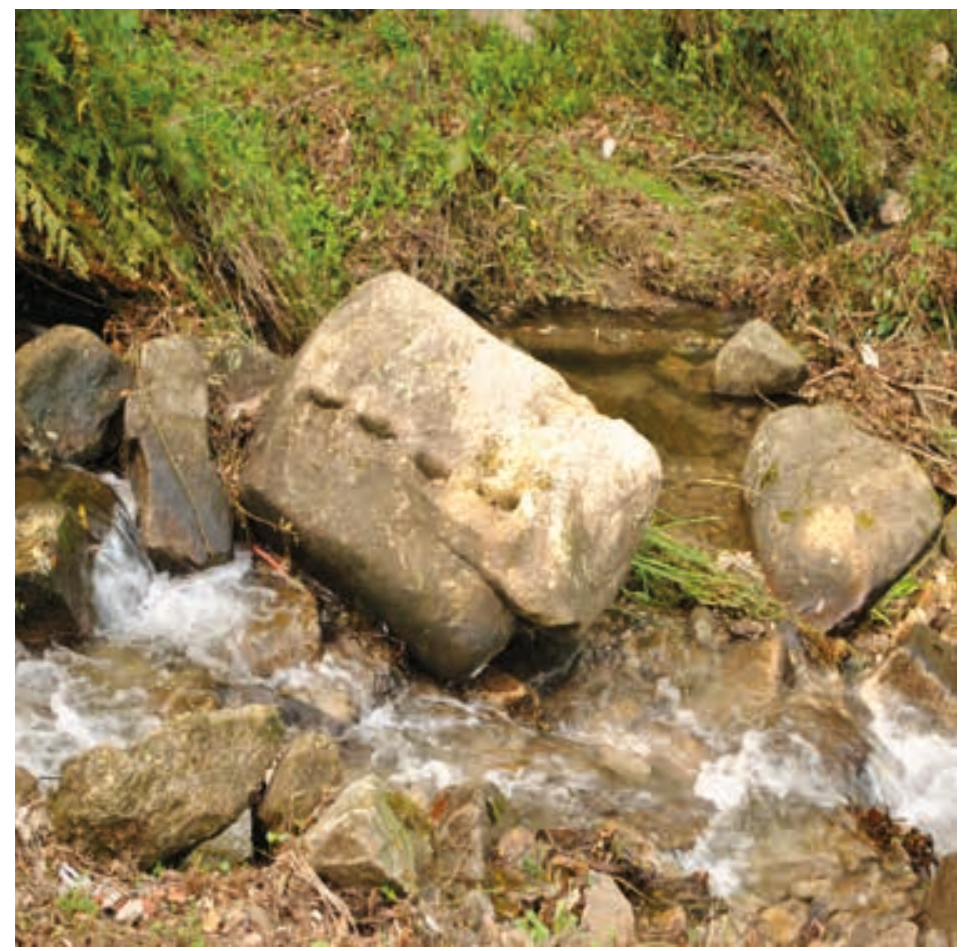

Traballos de cantaría nos muíños do Batán, en Salcedo (Pontevedra)

Estas obras de enxeñaría popular son tanxibles, pero, cando nos achegamos a un río, outro dos aspectos dos cales non adoitamos ser conscientes desde o punto de vista patrimonial é o seu patrimonio inmaterial e o que no río implica, é dicir, a multitude de lendas, anécdotas e vivencias ao redor del. 
O uso intenso ao que eran sometidos os muíños pola necesidade de contar sempre con fariña fresca para facer pan; o sistema de posesión e herdanza de moitos muíños, repartidos entre varias familias; as zonas de lavado e clareo de roupa no río, ou as zonas de tratamento do liño e de pesca converteron os ríos e os seus camiños de servidume en auténticos espazos públicos, percorridos por numerosas persoas ao longo de varias xeracións, tanto durante o día coma á noite, cando moitos muíños debían continuar moendo para dar a suficiente produción aos seus propietarios.

A comprensión do río como un espazo máis da paisaxe tradicional, pero moito máis frecuentado ca outras zonas da propia paisaxe, provoca que se xeren multitude de lendas e tradicións arredor da súa figura. Por exemplo, por mencionar un caso entre milleiros, a tradición da ponte da Senra, en San Cibrán de Ribarteme (As Neves), segundo a cal unha muller cun embarazo difícil debía colocarse baixo a ponte mentres dous familiares facían garda na zona superior para dar conta dos primeiros home e muller que pasasen, que se converterían nos padriños do neno. Se isto se cumpría, o parto iría ben, mais se os familiares non eran quen de controlar o paso dun can ou outro animal pola ponte, a muller abortaría.

Os ríos galegos son espazos de tradición e moito traballo, mais tamén espazos de troula, por mor da cantidade de noites pasadas a moer no muíño. Así o testemuñan numerosas coplas e a máis ca probable orixe da muiñeira, asociada a estas troulas.

Porén, os usos e tradicións que vimos de referir son propios dunhas sociedades cunha realidade agrogandeira e vinculada coa paisaxe dunha maneira moi diferente á sociedade actual. As estampas destes muínos en uso, así como as do río como un dos espazos máis transitados e empregados da parroquia, xa quedaron para o recordo e os libros de historia. Este rico patrimonio esmorece, física e inmaterialmente; fisicamente ante o abandono dos usos agrícolas tradicionais, con multitude de muínos caídos en desuso sen alguén que os traballe e, por tanto, os manteña ou tamén, desde unha perspectiva hidráulica, dadas as numerosas destrucións derivadas da xestión das administracións públicas. Cada vez son menos os lavadoiros en uso, máis os pasos e pontellas destruídos e moitos menos os muínos con capacidade de moer, como tamén cada vez son menos as persoas con recordos dos usos destes espazos hidráulicos tradicionais, das súas lendas, a súa toponimia etc., debido ao proceso de avellentamento e despoboamento do rural. 
Así e todo, co patrimonio hidráulico prodúcese unha situación interesante tendo en conta que as políticas de xestión integral do patrimonio dos concellos, no tocante á conservación e divulgación, son en moitos casos inexistentes. Os muíños e outros elementos hidráulicos coma os lavadoiros sempre tiveron unha posición privilexiada. Son numerosas en toda Galicia as obras de rehabilitación de muíńos, troco de cubertas, restitución de muros, arranxo de pontellas e lavadoiros, creación de sinalética e infraestrutura interpretativa a carón dos ríos etc.

Un exemplo significativo son os múltiples obradoiros de emprego dedicados aos traballos de mellora ou recuperación de muíños, que adoitan deixalos coas cubertas novas e a pedra totalmente limpa. Prima unha hipotética rehabilitación dun elemento que, en estado de ruína, fosiliza o abandono da paisaxe tradicional e os trocos históricos da nosa sociedade, dáse prioridade á súa recuperación óptima fronte a unha consolidación da ruína que podería explicar e evidenciar cambios sociais e históricos complexos e próximos a nós. Ambas as situacións son importantes, tanto o uso dos muíños coma o seu abandono, e non debería primar unha sobre a outra simplemente polo seu valor estético, como aparentemente sucede.

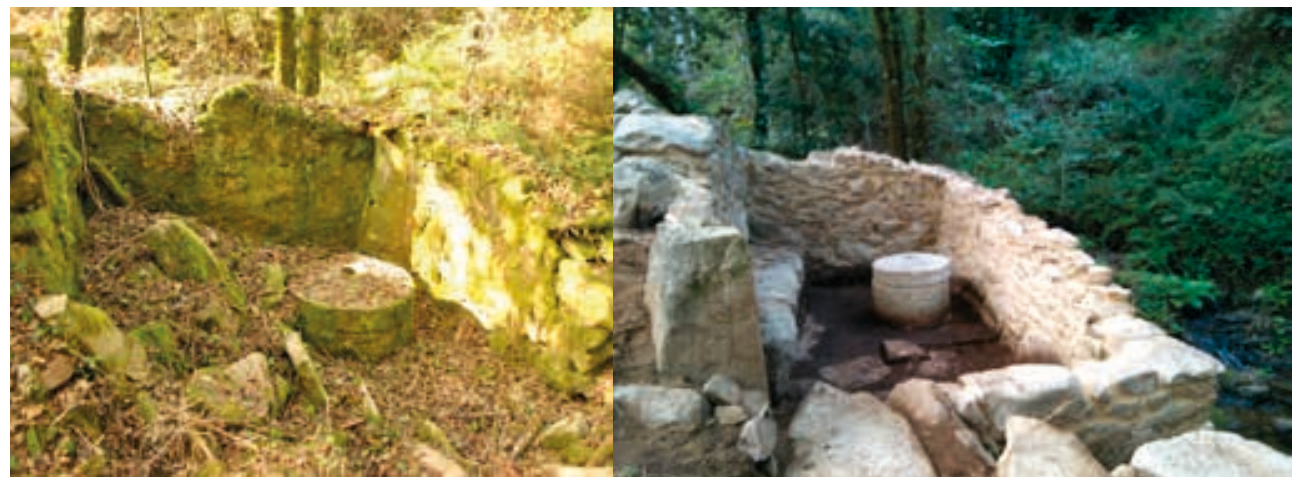

Consolidación de ruína de muíño, Salcedo (Pontevedra)

Os numerosos traballos con intención patrimonial en contextos hidráulicos destacan fronte ao tradicional abandono que adoitan sufrir outros bens do patrimonio coma, por exemplo, algúns elementos arquitectónicos ou arqueolóxicos. Poderiamos achacar esta tendencia das administracións a investiren maiores esforzos e contías económicas na conservación do patrimonio hidráulico ao valor estético que aínda conservan moitos dos nosos ríos, grazas aos seus 
bosques de ribeira, ben preservados. No entanto, este argumento desbotaría o escaso investimento noutros espazos de similares características estéticas e tamén con patrimonio singular. Talvez o feito de que moitas administracións, maioritariamente concellos, invistan nestes espazos se deba á aínda forte vinculación da nosa sociedade cos usos e costumes máis recentes na paisaxe tradicional. A conservación destes espazos é un recordo do valor funcional que, non hai tanto tempo, estas infraestruturas hidráulicas posuían, mais o valor que os espazos vinculados aos ríos teñen na actualidade xa non é tal.

Estes espazos xa non son necesarios desde unha óptica alimenticia, xa non se precisa que os muíños moian día e noite, posto que o millo galego xa non se destina a facer pan. A sociedade xa non precisa que os lavadoiros sexan espazos de aseo e comunicación social debido ás individualizadoras lavadoras. Por tanto, ante a ausencia de políticas que outorguen un novo valor a este patrimonio, son numerosos os casos en que volven ao abandono, incluso despois de cuantiosos investimentos.

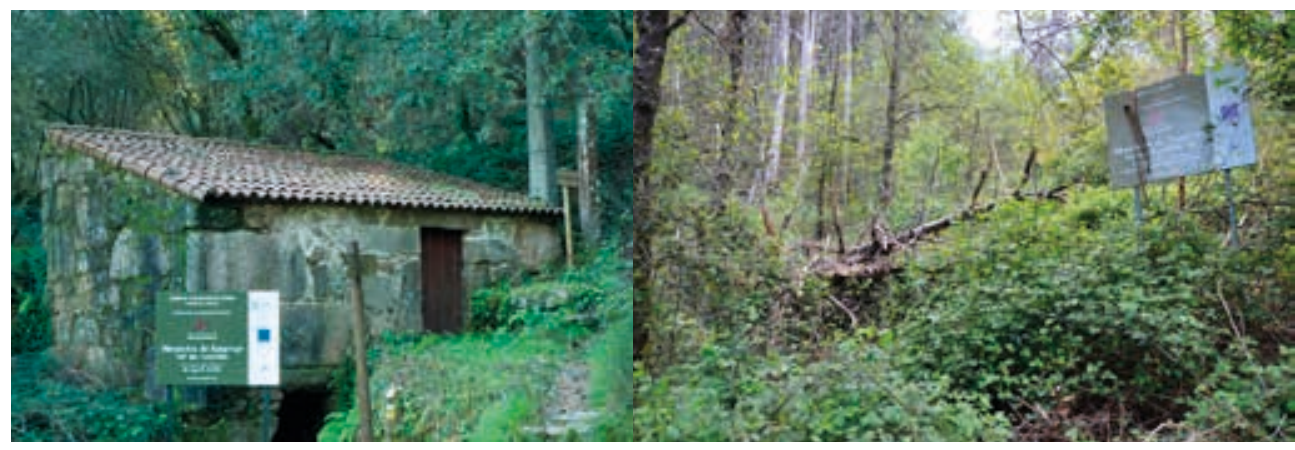

Resultado dos traballos do Obradoiro de emprego Val da Louriña. Imaxe esquerda: Wikiloc. Cartel e muíño abandonado tras o Obradoiro de emprego Val da Louriña II. Imaxe dereita: comarcasnarede.com

$\mathrm{O}$ valor patrimonial destes espazos presúmese, pero isto non significa que a sociedade sexa consciente ou que para mantelo non sexan necesarias políticas con certa constancia no tempo. Por un lado, como punto de partida para a súa conservación, é preciso coñecer en detalle o seu espazo e singularidades históricas. En moitos casos en que se realizaron tarefas de conservación, non existiu un proceso de documentación nin investigación desde unha perspectiva histórica. Adoita pensarse que todos os cursos fluviais se comportan historicamente da mesma 
maneira e esta afirmación utilízase como xustificación para a escasa investigación nesta temática. Por outro lado, faltan tamén obras de conxunto que poñan en común as ricas realidades de Galicia a respecto do patrimonio cultural hidráulico; obras que aglutinen investigacións locais excelentes, coma, por exemplo, a de Ramiro Barros Justo (2005) sobre os muíños das terras de Pontevedra, e fornezan unha perspectiva global galega.

Unha vez dado o primeiro paso de documentación e investigación histórica, cómpre divulgar o coñecemento adquirido a través dunha perspectiva vinculada á interpretación do patrimonio, unha disciplina comunicativa que busca transmitir ao visitante, sexa turista ou non, uns conceptos e significados do patrimonio cultural e natural co obxectivo de xerar nel sensacións e emocións que fomenten a apreciación e singularización dos bens en cuestión (Sam Ham e Jorge Morales, $\left.\mathrm{AIP}^{1}\right)$. Tanto a través de intérpretes do patrimonio coma por medio das infraestruturas de interpretación axeitadas, pódese conseguir o fin de vincular as comunidades locais co seu patrimonio, para que exerzan de primeiros custodios del.

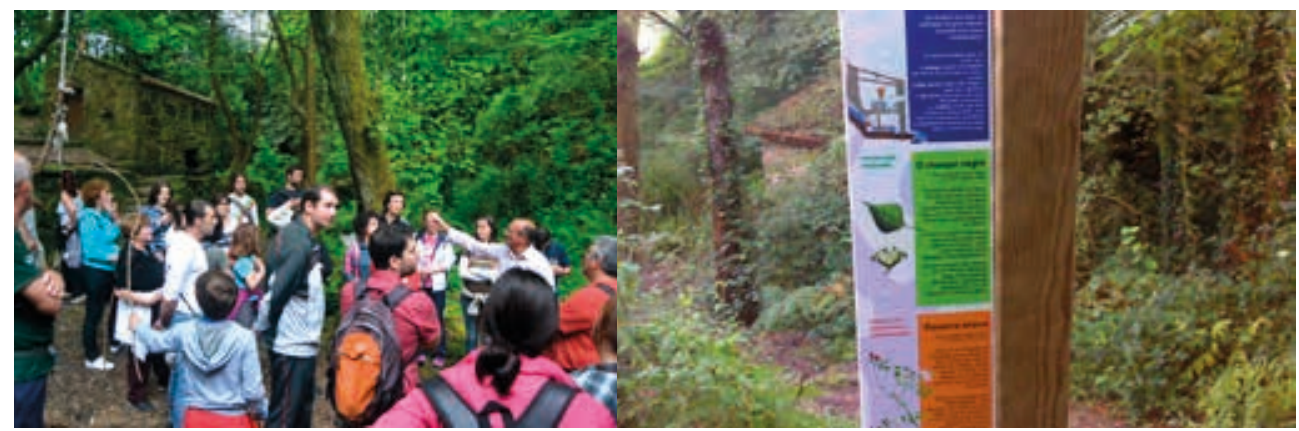

Visita guiada no río Frade (Bueu) e infraestrutura de interpretación do río Eifonso (Vigo)

As comunidades locais garanten a estabilidade de eventos vinculados aos usos tradicionais do río e do seu patrimonio, coma por exemplo o Encontro-Degustación do Millo Corvo, en Bueu, que xa vai pola súa XXI edición e divulga os valores da agricultura tradicional na figura dunha das variantes negras do millo americano, así como con exemplos de moenda no río Frade, en Meiro. Trátase dunha Festa de Interese Turístico de Galicia.

1 https://www.interpretaciondelpatrimonio.com/es/definiciones 


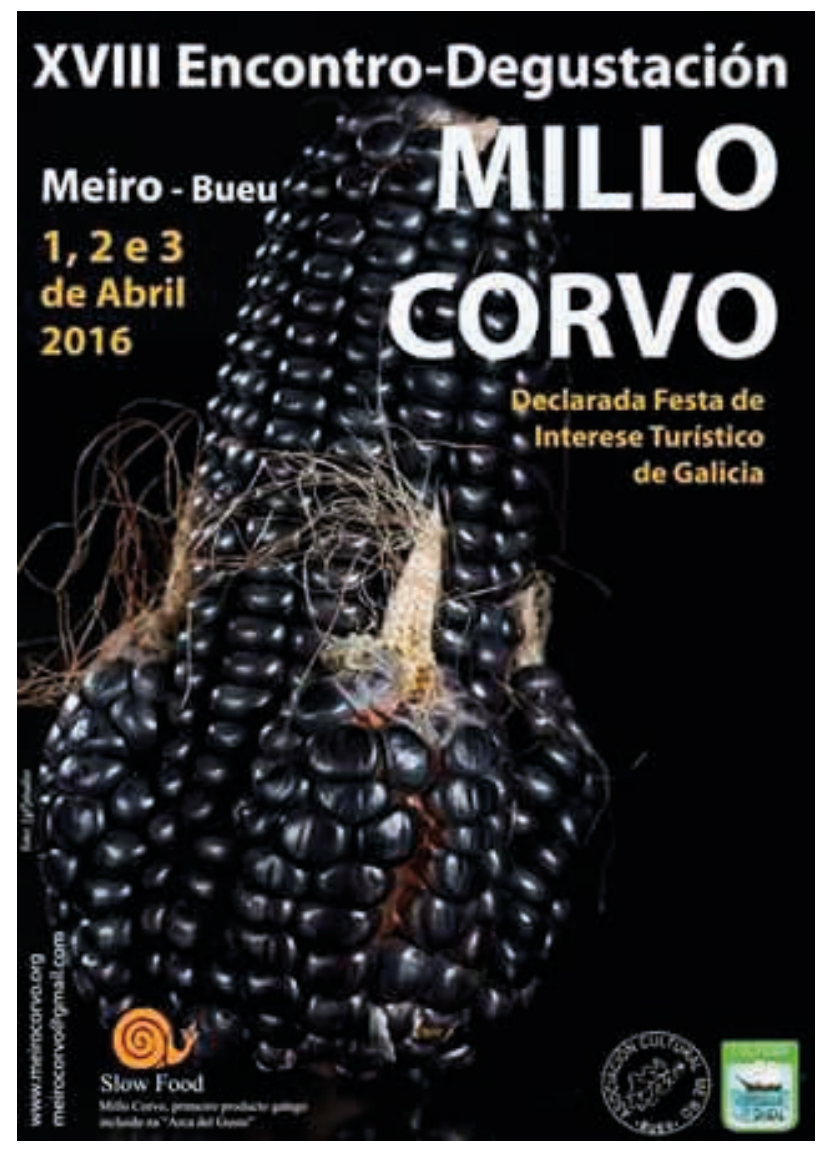

Cartel do XVIII Encontro-Degustación do Millo Corvo

A través do tipo de políticas anteriormente referidas, pódense fornecer valores que fomenten o aprecio e preocupación pola conservación do patrimonio, así como o lecer e a educación nestes espazos, xerando valores patrimoniais de tipo identitario, social ou económico.

Nunha sociedade para a cal os valores de uso do patrimonio cultural hidráulico xa están perdidos, pódense fornecer novos valores máis aló do estritamente patrimonial co obxectivo de garantir unha conservación e usos axeitados deste patrimonio. Existe a posibilidade de empregar actividades de corte máis clásico coma a divulgación e o uso destes espazos para lecer público, así como o emprego dalgún deles como establecementos de hostalaría, conservando as súas 
arquitecturas e os elementos tradicionais, que os contextualizan. Ademais, hai outros proxectos (que cómpre que conten coa autorización das administracións competentes) que poderían volver garantir uns ríos nos que os muíños e outros elementos, abandonados non hai moito tempo, recuperasen o seu uso hidráulico. É o caso da recuperación das numerosas pequenas centrais hidroeléctricas que ocupaban os nosos ríos e que incluso non eran máis grandes ca un muíño. A tecnoloxía actual, con pequenas turbinas que permiten xerar até $15 \mathrm{~kW}$, había posibilitar a recuperación de numerosos infernos de muínos desde unha óptica de conservación do patrimonio, pero tamén produtiva. Isto había permitir integrar os valores patrimoniais dos nosos ríos xunto cos valores ecolóxicos e económicos da sociedade actual, camiñando cara á preservación conxunta do patrimonio cultural e do natural, co obxectivo de conseguir ríos que nazan frades e morran bispos, non ao revés. 
UN RÍO QUE NACE FRADE E MORRE BISPO OU NACE BISPO E MORRE FRADE. APUNTAMENTOS SOBRE O PATRIMONIO CULTURAL HIDRÁULICO GALEGO

\section{REFERENCIAS BIBLIOGRÁFICAS}

Barrart i Hernández, Jospep / Josep Manuel Fullola i Pericot / María dels Ángels Petit i Mendizábal (1996): «El valor del patrimonio histórico», Complutum Extra, 6:2, 215-224.

Barros Justo, Ramiro (2005): Muiños de río das Terras de Pontevedra, Pontevedra, Servizo de Publicacións da Deputación de Pontevedra.

Bas López, Begoña (1991): Muiños de marés e de vento en Galicia, A Coruña, Fundación Pedro Barrié de la Maza.

CAAMAÑo SuÁREZ, Manuel (2003): As construccións da arquitectura popular: patrimonio etnográfico de Galicia, Santiago de Compostela, Consello Galego de Colexios de Aparelladores e Arquitectos Técnicos.

Miró Alaix, Manel (2000): «Construir el territorio museo: una propuesta para la gestión creativa del patrimonio cultural en áreas rurales», Actualidad Leader: Revista de Desarrollo Rural, 12, 8-9. 



\section{A XESTIÓN DO PATRIMONIO CULTURAL DOS RIOS EN GALICIA. PROTECCIÓN E CONSERVACIÓN \\ Teresa Nieto \\ Arquitecta \\ Xunta de Galicia}

DOI: 10.17075/pvpcr.2021.008 

O contido das xornadas «A posta en valor do patrimonio cultural dos ríos: Galicia e outros exemplos» responde a unha consideración territorial do patrimonio cultural non só porque se establece unha relación entre patrimonio natural e cultural, senón porque se trata de bens, materiais e inmateriais, considerados conxunta e diacronicamente, que son manifestación da propia e particular forma de relacionarse co medio, do aproveitamento dos seus recursos, das sociedades que habitaron un territorio. En Galicia, os ríos son omnipresentes e están directamente relacionados coa ocupación do territorio, como nos describe Miguel Anxo Murado en Outra idea de Galicia:

O nome poético de Galicia, «país dos dez mil ríos», queda curto; son moitos máis. No mapa, eses ríos forman un labirinto intricado, unha especie de rede neuronal. Non son só a consecuencia do ceo e as súas chuvias, tamén o son da terra. Durante o pregamento alpino, o pedestal de granito que é Galicia fracturouse nun sen fin de valiñas, e non hai ningunha delas, por pequena que sexa, que non estea percorrida por un curso de auga. Galicia sempre foi así, unha maraña de pequenos núcleos de poboación repartidos arredor doutra maraña previa de ríos e regatos.

Esta proximidade e relación entre a poboación e os ríos que forman parte do seu contorno territorial fai que se localicen neses espazos, con especial intensidade, manifestacións do que a Lei do patrimonio cultural de Galicia define como «a interacción e interpretación que a comunidade fai do medio natural que o sustenta e que constitúe o soporte material da súa identidade».

\section{A PROTECCIÓN DO PATRIMONIO CULTURAL DOS RÍOS EN GALICIA}

Malia que o Estatuto de autonomía de 1981 atribuíu á Xunta de Galicia a competencia exclusiva sobre o patrimonio histórico, artístico, arquitectónico e arqueolóxico de interese de Galicia, até a aprobación da Lei do patrimonio cultural de Galicia (LPC) do ano 1995 Galicia non se dota dunha norma propia de protección do patrimonio cultural axeitada á realidade de Galicia, como sinala a súa exposición de motivos. 
Até ese momento, o patrimonio protexido en Galicia compúñano aqueles bens que foran declarados histórico-artísticos ou incluídos no Inventario de Patrimonio Artístico e Arqueolóxico de España, e que pasaran a ter a consideración de Bens de Interese Cultural recoñecida pola Lei do patrimonio histórico español (LPHE) na súa disposición adicional primeira. Teñen esta condición de Bens de Interese Cultural unicamente catro bens vinculados aos ríos: a ponte Bibei, a ponte Pedriña, a ponte Vella de Ourense e o muíño de San Mamede de Moldes, aos que unicamente se engadiron, xa desde a Xunta de Galicia, os muíños de Folón e Picón como lugar de interese etnográfico e a ponte de Pontevea, declarada recentemente.

Nese período de ausencia dunha norma propia de protección do patrimonio en Galicia, acudiuse a unha figura urbanística: as Normas Subsidiarias Provinciais de Planeamento, para ampliar a protección patrimonial a unha serie de bens inmobles que se recolleron no seu Inventario do Patrimonio Histórico-Artístico por Concellos. Inaugurábase así unha técnica protectora apoiada no planeamento urbanístico que, como veremos, aínda se mantén en gran medida. Esa protección, semellante á que máis tarde establecerá a Lei do patrimonio cultural, baseábase no control administrativo das intervencións sometidas á autorización urbanística, tanto se eran directas sobre os bens protexidos coma sobre as franxas xenéricas de protección que as propias Normas Subsidiarias establecían.

No Inventario desas Normas Subsidiarias incluíase a maior parte das pontes máis relevantes e un número importante de muíños, aínda que é certo que cunha distribución totalmente irregular, como evidencia o feito de que, dos pouco máis de 80 muíños recollidos nese inventario, case 50 estean situados no concello de Lugo.

A Lei do patrimonio cultural de Galicia do ano 1995 mantén a consideración de bens de interese cultural a aqueles bens que xa a tiñan recoñecida pola LPHE e incorpora a outra das categorías que se crean nesta lei, a de bens inventariados, todos os bens recollidos no Inventario de Patrimonio Histórico Artístico das Normas Subsidiarias de Planeamento referidos previamente, ademais daqueles bens incluídos no catálogo de calquera outra figura de planeamento urbanístico.

Esta última incorporación, se ben aumentou en gran número os bens protexidos, tamén incrementou a dispersión respecto da localización xeográfica dos bens por dúas razóns: a inexistencia de planeamento e de catálogos en gran número de concellos, e a insuficiente catalogación do patrimonio rural naqueloutros onde 
si se elaboraran catálogos. A modo de exemplo para ilustrar esta situación, o catálogo do PXOM de Vigo do ano 1993 incluía máis de 100 muíños, pontes e algunhas presas, mentres que o de Pontevedra do ano 1994 incluía, ademais das pontes, unicamente tres conxuntos de muíños e outro illado. A esa ausencia de bens nalgúns concellos engádese o feito de que o tipo de bens protexidos relacionados cos ríos estea limitado case exclusivamente ás pontes e aos muínos. A incorporación nos planeamentos doutro tipo de elementos é puntual e realízase alí onde existe algún cunha especial singularidade ou recoñecemento patrimonial, coma o caso das pesqueiras do río Miño de Arbo, que se recollen no catálogo de planeamento deste concello, pero non no doutros concellos onde existen.

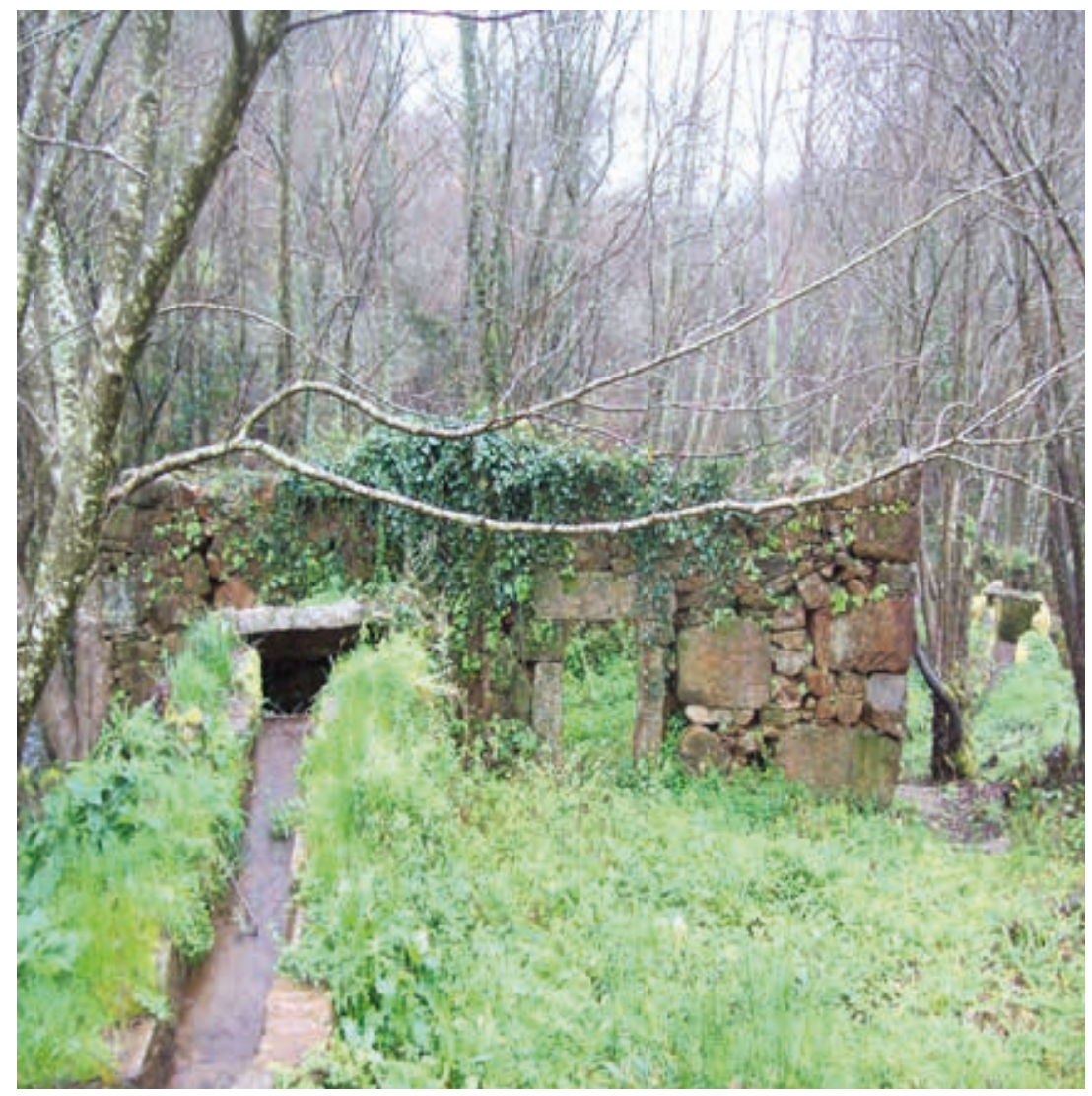

Imaxe 1. Dous muíños do conxunto de Soloeido, no río Vilaza, na parroquia de Zamáns en Vigo, antes da súa restauración 
A identificación e protección refírese principalmente ás edificacións, obviando no caso dos muíños as infraestruturas hidráulicas, que por veces teñen gran complexidade e extensión; elementos menores coma pasais e pontellas nos ríos, ou elementos coma os relacionados co patrimonio industrial de recoñecemento patrimonial máis recente.

A Lei do patrimonio cultural, malia incluír dentro das categorías de bens de interese cultural algúns de ámbito territorial coma os conxuntos históricos, os lugares de interese etnográfico ou os sitios ou territorios históricos, non tiña unha consideración territorial do patrimonio cultural. A protección centrábase nos elementos illados e nas zonas delimitadas, na maior parte dos casos como contornos xenéricos de protección fixados por distancia, mais sen unha visión integrada do patrimonio cultural no territorio.

O concepto de patrimonio da Lei de 1995 comprendía tanto os bens mobles e inmobles coma os aspectos inmateriais, aínda que tratados como categorías separadas, lonxe dun tratamento integral do patrimonio cultural. Esa protección dos bens inmateriais tiña especial relevancia no título que a lei dedicaba ao patrimonio etnográfico, onde se protexían xenericamente os coñecementos, actividades, prácticas, saberes e calquera outra expresión de modelos, técnicas, funcións e crenzas propias da vida tradicional galega, e que instaba a Administración a promover e adoptar medidas para o seu estudo e documentación científica, a fin de garantir a súa transmisión e posta en valor. Porén, a protección do patrimonio inmaterial foi (e aínda é) practicamente inexistente e apenas se realizaron inventarios ou traballos de recollida, nin en relación cos ríos, nin de carácter xeral ${ }^{1}$. Así, coa extinción da vella sociedade agraria e o abandono que sofre o territorio rural en Galicia, non só se foron perdendo lendas e mitos, senón tamén usos, tradicións e técnicas ligadas á intensa utilización dos ríos e dos seus recursos.

En relación cos bens materiais de carácter etnográfico, o artigo 66 da Lei do patrimonio cultural de 1995 acollía dúas consideracións relevantes: un reco-

1 Como recolle Xerardo Pereiro Pérez en «La concepción del patrimonio etnoantropológico en Galicia: visiones legales y practicas institucionales", publicado na Revista Andaluza de Antropología n. ${ }^{\circ} 2$, de marzo de 2012: «No período 1992-1994 desde a Sección de Etnografía da Dirección Xeral de Patrimonio Histórico e Documental desenvolvéronse tres convocatorias de axudas á investigación do patrimonio etnográfico, que comprenderon fundamentalmente traballos de inventario e clasificación». 
ñecemento nesa categoría dos restos físicos do pasado tecnolóxico, produtivo e industrial galego, ampliando ao carácter industrial os valores recoñecidos a ese patrimonio cultural, e a posibilidade de que eses bens fosen estudados cunha metodoloxía arqueolóxica. Incluía así os restos do patrimonio preindustrial e industrial, de especial relevancia no territorio dos ríos, e a consideración deses restos físicos como fonte de estudo e coñecemento da sociedade e da cultura que os creou, é dicir, a consideración dos bens materiais como documento.

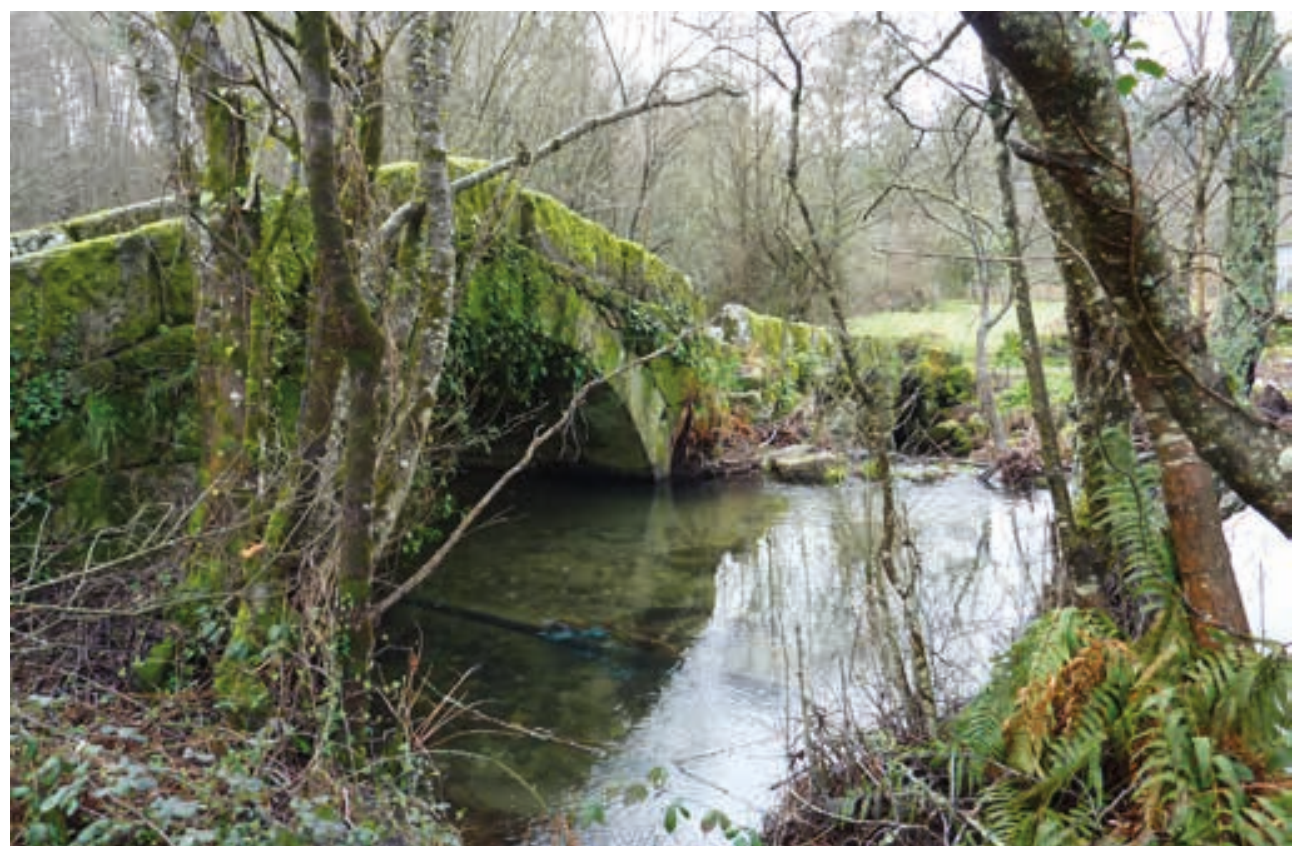

Imaxe 2. Ponte Noceifas sobre o río Ribadil, na parroquia do Couto (A Cañiza), catalogada no ano 2003

A entrada en vigor de dúas normas sectoriais: a Lei 5/2006, do 30 de xuño, para a protección, a conservación e a mellora dos ríos galegos, e as Directrices de Ordenación do Territorio de Galicia, tiveron especial relevancia na protección do patrimonio cultural dos ríos.

A Lei 5/2006 estableceu, no seu artigo 1, como prioridade de interese xeral da Comunidade Autónoma de Galicia a conservación do patrimonio natural fluvial que inclúe o patrimonio etnográfico e histórico-cultural relacionado, e declarou que era obriga das administracións públicas galegas garantir a súa 
protección, conservación e mellora. A partir da entrada en vigor desta norma, a Dirección Xeral de Patrimonio vén requirindo aos planeamentos urbanísticos, nos informes que emite, a localización e identificación dos bens do patrimonio cultural relacionados cos ríos e a súa protección, unha protección que até entón se consideraba discrecional e quedaba á vontade do Concello que elaboraba o plan.

As Directrices de Ordenación do Territorio aprobadas en 2011 recoñecen a existencia de moitos elementos patrimoniais esquecidos, carentes de protección, polo que consideran prioritario desenvolver o coñecemento do territorio para identificalos, caracterizalos e posibilitar a súa protección, ademais da súa valorización e uso. Para conseguir este obxectivo establecen nas súas determinacións a obrigatoriedade de desenvolver unha prospección, entendida como a exploración e recoñecemento sistemático do ámbito de estudo para a detección de elementos do patrimonio cultural non-identificados no Inventario de Patrimonio Cultural de Galicia, con especial incidencia sobre o patrimonio etnográfico e arqueolóxico. Esta disposición dálle carácter normativo a unha esixencia da Consellería de Cultura que, no ámbito dos plans, programas e proxectos con incidencia sobre o territorio que se debían someter ao seu informe, establecía dentro das medidas protectoras e correctoras do patrimonio cultural a obriga de desenvolver esas prospeccións, inicialmente limitadas ao patrimonio arqueolóxico, pero máis tarde ampliadas a calquera clase de bens.

Estas prospeccións permitiron identificar un gran número de bens, tamén entre os vinculados aos ríos, mais esa identificación unicamente veu seguida da súa protección naqueles localizados no procedemento de tramitación dos planeamentos municipais que os incorporaron aos seus catálogos, xa que para os bens que se identificaron nos procedementos de avaliación de impacto ou efecto ambiental ou na tramitación de proxectos sectoriais non se tramitaron procedementos de inclusión no Inventario Xeral do Patrimonio Cultural de Galicia.

Ao longo desas décadas, mantívose a carencia dun inventario e dunha catalogación completa que asegurase o coñecemento e a protección preventiva dos bens do patrimonio cultural, moitos localizados mais non protexidos, e que corrixise as carencias ás que daba lugar a recompilación dos bens dos catálogos municipais coa súa heteroxeneidade e concentración de datos en determinadas áreas. Esta falta de protección foi especialmente grave para moitos dos bens vinculados aos 
ríos, onde o desuso e o abandono levaron moitos deles á ruína e incluso á perda da memoria da súa existencia.

A vixente Lei do patrimonio cultural, do ano 2016, establece unha categorización do patrimonio cultural en patrimonios específicos. Esta categorización, malia a manifestación que se fai na súa exposición de motivos de non ignorar a profunda unidade do patrimonio cultural, non contribúe a unha visión integrada dos valores culturais do patrimonio como a que dunha maneira indiciaria apuntaba a regulación do patrimonio etnográfico na anterior lei. Deste xeito, os bens do patrimonio cultural dos ríos son acollidos na categoría de patrimonio etnolóxico, coma os batáns e os muíños de río, as pontellas tradicionais ou as embarcacións tradicionais dos ríos de Galicia; no patrimonio industrial, coma os lugares, instalacións, fábricas, edificios e obras de enxeñaría destinadas á produción e transporte da enerxía e coma as mostras singulares da arquitectura de ferro, incluídos os mercados, pontes e viadutos, ou no patrimonio arquitectónico, coma as construcións propias das obras públicas e a enxeñaría histórica nas que se inclúen as pontes, as presas, as canles e os abastecementos. A dimensión arqueolóxica deses bens desaparece xa que, aínda que a lei mantén na definición do patrimonio arqueolóxico a referencia á metodoloxía arqueolóxica, o seu estudo agora vese limitado aos restos da antigüidade.

Esta distribución e os diferentes réximes de protección establecidos para cada patrimonio específico non contribúen á visión unitaria do patrimonio cultural; pola contra, a definición na lei de bens de dimensión territorial que acollan o conxunto dos elementos incluídos nas diferentes categorías está no camiño do recoñecemento territorial do patrimonio que apreciamos nesta xornada e que pode contrapesar a deriva sinalada.

Destas clases de bens de dimensión territorial, dúas son de singular importancia: a de lugar de valor etnolóxico que xa contemplaba a lei anterior e que foi na que se incluíu a declaración do conxunto dos muínos do Folón-Picón, no concello do Rosal, como ben de interese cultural, e a da paisaxe cultural que corresponde ao territorio da Ribeira Sacra, que vén de ser declarado tamén ben de interese cultural, e que ten os ríos Miño e Sil como os elementos xeográficos que relacionan e cos que se relaciona o territorio que se declara. 


\section{AS ACTUACIÓNS SOBRE O PATRIMONIO CULTURAL DOS RÍOS DE GALICIA}

Se limitada foi, e segue sendo, a protección do patrimonio dos ríos, tamén o foron as políticas públicas destinadas á súa conservación e recuperación. En dous períodos, na década de 1990 e máis recentemente entre os anos 2007 e 2009, a Consellería de Cultura convocou axudas destinadas a actividades de fomento para a conservación e a restauración de bens do patrimonio etnográfico de Galicia. Entre estes bens incluíanse os muíños que ou ben estivesen recollidos no catálogo dun instrumento urbanístico, e por tanto formasen parte do Inventario de Patrimonio Cultural de Galicia, ou ben estivesen situados dentro do contorno doutro ben protexido ou no territorio histórico do Camiño Francés. Outras actuacións, aquelas promovidas directamente pola Consellería de Cultura, tiveron por obxecto principalmente a restauración das pontes históricas.

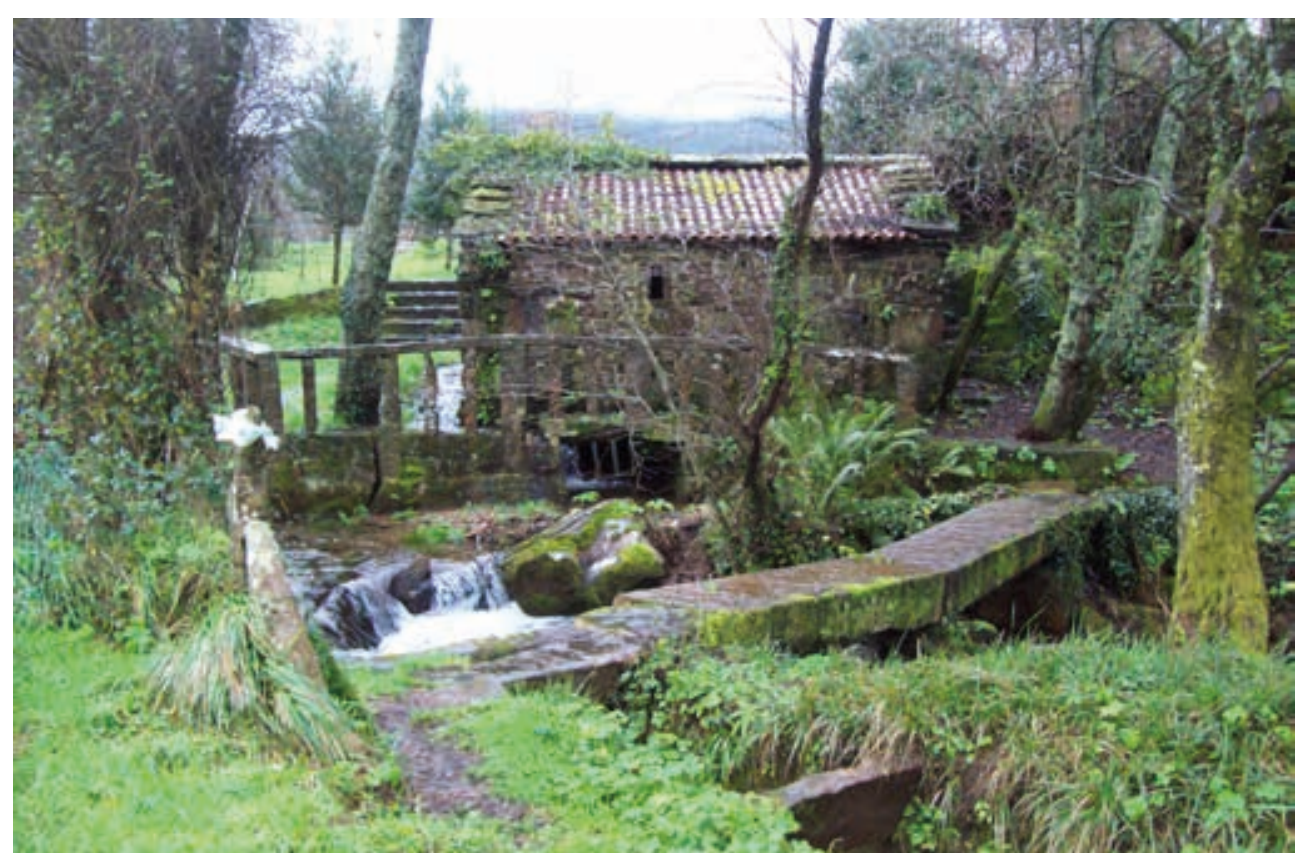

Imaxe 3. Un dos muíños restaurados en Zamáns (Vigo) 
Desde o ámbito local, desenvolvéronse actuacións relacionadas co uso recreativo dos espazos naturais dos ríos. Son numerosas as áreas de baño e ocio que se acondicionaron, aproveitando as zonas naturais aptas para iso, pero tamén, en moitos casos, pequenas presas creadas para o aproveitamento da auga en sistemas de rega ou nos muíños. Moitos deses acondicionamentos realizáronse a través de escolas-obradoiros ou de axudas relacionadas co desenvolvemento rural. Aínda que a maior parte comprenden, ademais das presas xa citadas, muíños, pontellas ou pasais e elementos semellantes, as actuacións de recuperación destes bens do patrimonio cultural non foron nin o motor nin o obxecto principal destas actuacións. Cando se realizaron, limitáronse principalmente ás construcións dos muíños e non incorporaron unha recuperación integral dos sistemas hidráulicos nin dos mecanismos. Estas actuacións foron tamén en moitos casos creadoras de fortes impactos sobre os espazos naturais e o patrimonio cultural debido ás infraestruturas e servizos que as acompañaron: accesos e estacionamentos, construcións para aseos, servizos, locais de hostalaría, tratamento urbano dos espazos de ribeira, plantacións e axardinamentos.

Promovéronse tamén diversas rutas de sendeirismo e sendas fluviais ao abeiro do mesmo tipo de financiamento e dos fondos europeos que financiaban a creación de rutas e sendeiros naturais e a súa sinalización, e que consideraron prioritarios, entre outros, aqueles proxectos que contribuísen á promoción do patrimonio natural e cultural. Non podemos cualificar estas actuacións de auténticos itinerarios de coñecemento e apreciación do patrimonio do territorio, dos ríos en particular, pois

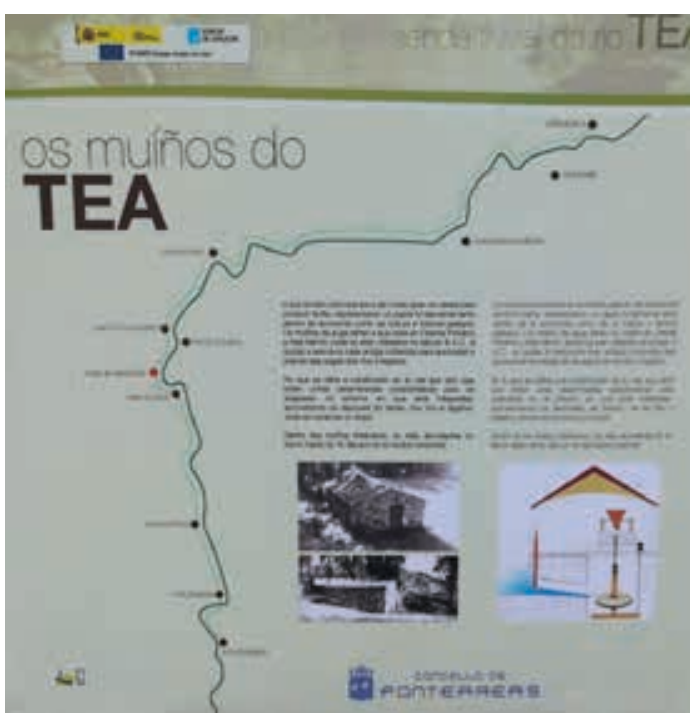

Imaxe 4. Cartel da senda fluvial do río Tea non foron deseñadas como tales, senón como rutas para o gozo do medio natural e da paisaxe ás que 
se suman os elementos patrimoniais que se localizan no seu percorrido como unha plusvalía. En moitos casos, nin sequera se realizan traballos de recuperación destes elementos, mantendo o romanticismo das ruínas tan apreciado no caso dos muíños, e noutros casos nos que si se efectúa, coma en pontes e pontellas, as intervencións con pavimentacións e proteccións que se levan a cabo non sempre son acertadas.

A recuperación dos muíños adoita estar limitada tamén ao volume, á restitución de cubertas das construcións e, nalgún caso, ás canles, e case nunca comprende o conxunto hidráulico nin os mecanismos interiores. As técnicas e materiais construtivos que se empregan responden á recuperación dunha «imaxe» que non sempre se corresponde coa autenticidade, ao introducir rexuntados, madeiras laminadas e carpintarías.

Un aspecto importante destas rutas pode estar relacionado coa recuperación do patrimonio inmaterial. A sinalización recupera a toponimia, os nomes dos lugares e tamén o nome daqueles bens desaparecidos e conservados na memoria neses nomes, como é o caso de muínos, pesqueiras, canais e presas.

Non debo esquecer mencionar as actuacións singulares que tiveron outro carácter, coma as levadas a cabo en Allariz para a recuperación paisaxística e medioambiental do río Arnoia e dos seus muínos e fábricas de curtidos (unhas para uso museístico etnográfico, outras destinadas a outros usos relacionados co ocio e a hostalaría, que se sumaron ao proceso de rehabilitación do seu casco histórico), que acadaron recoñecemento internacional, pero que lamentablemente non foron imitadas.

Vou describir, de maneira sucinta e a modo de exemplo, dúas actuacións (unha xa realizada e a outra aínda en fase de proxecto) nas que están presentes a multidimensionalidade do patrimonio cultural e a consideración territorial do patrimonio, dous factores aos que fixen referencia no inicio deste artigo.

\section{AS PESQUEIRAS DO MIÑO}

Existen referencias documentais do século XII da existencia de pesqueiras no río Miño, probablemente vencelladas a mosteiros e casas feudais, e algúns estudos apuntan incluso que a orixe desas estruturas é romana. 
Tradicionalmente, as obras de conservación das pesqueiras realizáronse periodicamente e de maneira solidaria, moitas veces empregando materiais e técnicas construtivas modernas, non-orixinais, primando mantelas en uso, xa que nunca se abandonaron.

Os concellos de Salvaterra e Arbo asumiron nos seus tramos do río cadansúa actuación de limpeza, restauración e consolidación de parte das pesqueiras con financiamento da Administración de Turismo, que as inclúe nos itinerarios da Ruta da Lamprea.

A Dirección Xeral de Patrimonio Cultural, na autorización das actuacións, considerou que intervencións coma as proxectadas aconsellaban que as desmontaxes nas zonas nas que se chega ao apoio sobre a rocha natu-

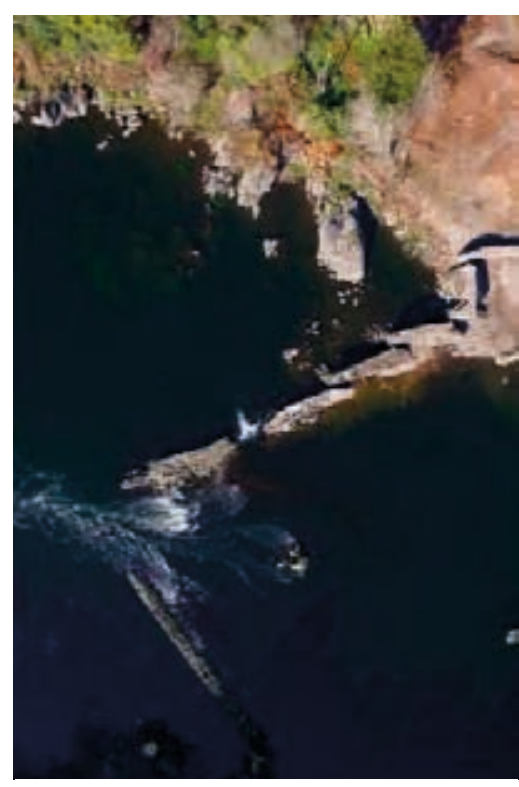

Imaxe 5. As pesqueiras do Miño, en Sela (Arbo) ral se realizasen seguindo unha metodoloxía arqueolóxica; documentando a composición das fábricas, a técnica construtiva e o tipo de material empregado; realizando previamente un estudo dos paramentos, e documentando e identificando elementos coma marcos, bancais na cabeza, antigos poios ou caneiros, niveis anteriores de soleira ou buracos para o peixe que documentasen a orixe e transformación destes elementos.

Por tanto, os traballos realizáronse en dúas fases: unha de limpeza e desmontaxe na que se desenvolveu o estudo e seguimento arqueolóxico, e unha segunda fase de reconstrución apoiada na documentación técnica precisa e detallada elaborada a partir do coñecemento e da documentación gráfica realizada na primeira fase, que permitiron definir con maior precisión e rigor a técnica construtiva que se vai empregar e o tipo de reforzos para garantir a solidez das estruturas.

Daquela, seguiuse unha metodoloxía propia da restauración monumental e da arqueoloxía da arquitectura, considerando o valor histórico documental destas estruturas, non unicamente o seu carácter de ben etnolóxico. 


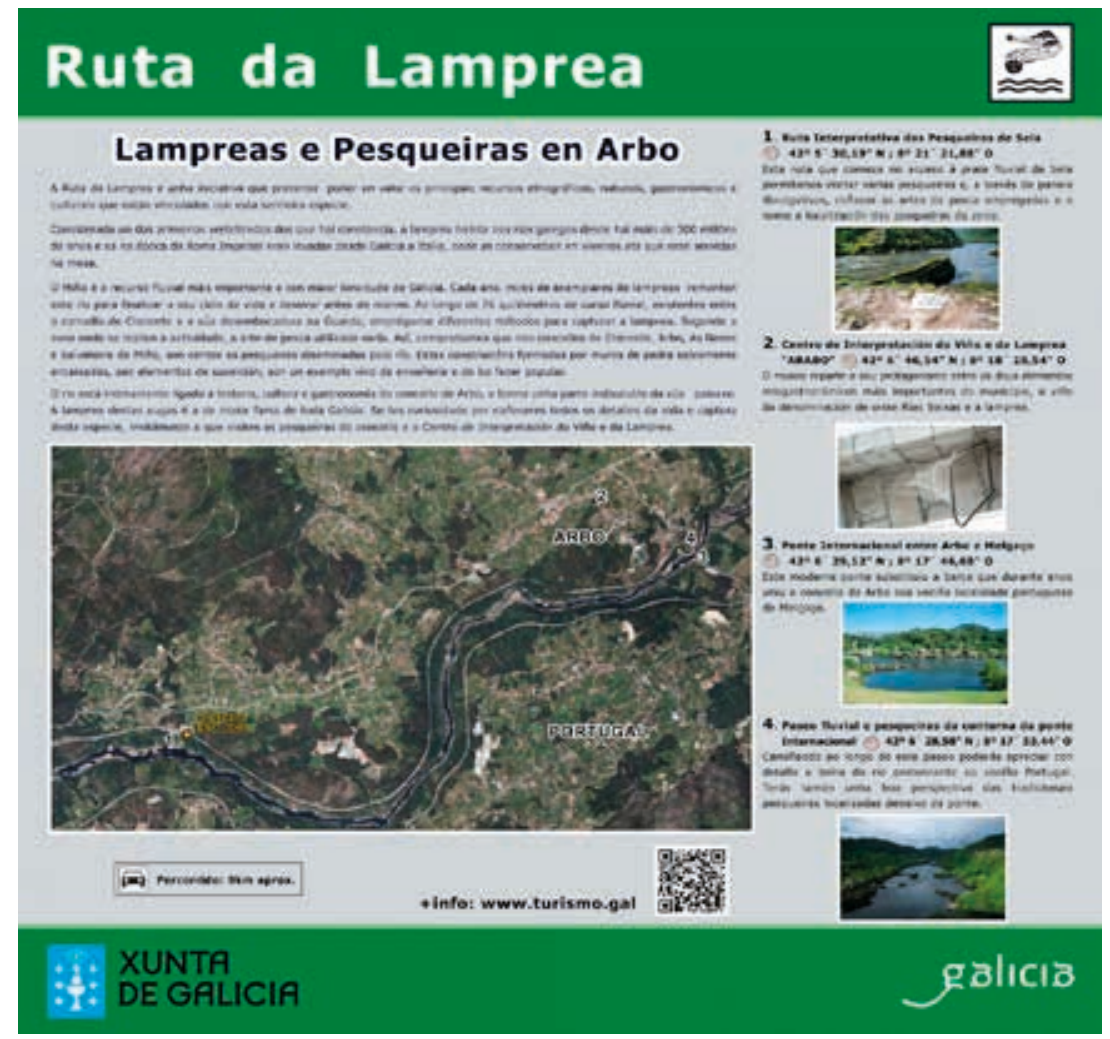

Imaxe 6. Cartel da Ruta da Lamprea que recolle as pesqueiras do Miño, en Sela (Arbo)

\section{OS BAÑOS DE SAN XUSTO NO RÍO LÉREZ, EN COTOBADE}

Cando, no ano 2013, o Concello de Cotobade elaborou o seu PXOM, non incluíu no seu catálogo ningún dos elementos situados na zona de San Xusto, a carón do río Lérez, onde o século Xx se iniciou coa posta en funcionamento da central hidroeléctrica promovida polo marqués de Riestra para mellorar a iluminación da cidade de Pontevedra, que até entón se realizaba desde unha central de vapor instalada na praza da Verdura. Ademais da propia central e a súa infraestrutura, canle e depósitos, existiu nas súas inmediacións, nesa marxe do río Lérez, unha zona de baños termais con bañeiras exteriores coñecida como «Os Baños de San Xusto» e tamén se conservan varios muíños na beira do río. 


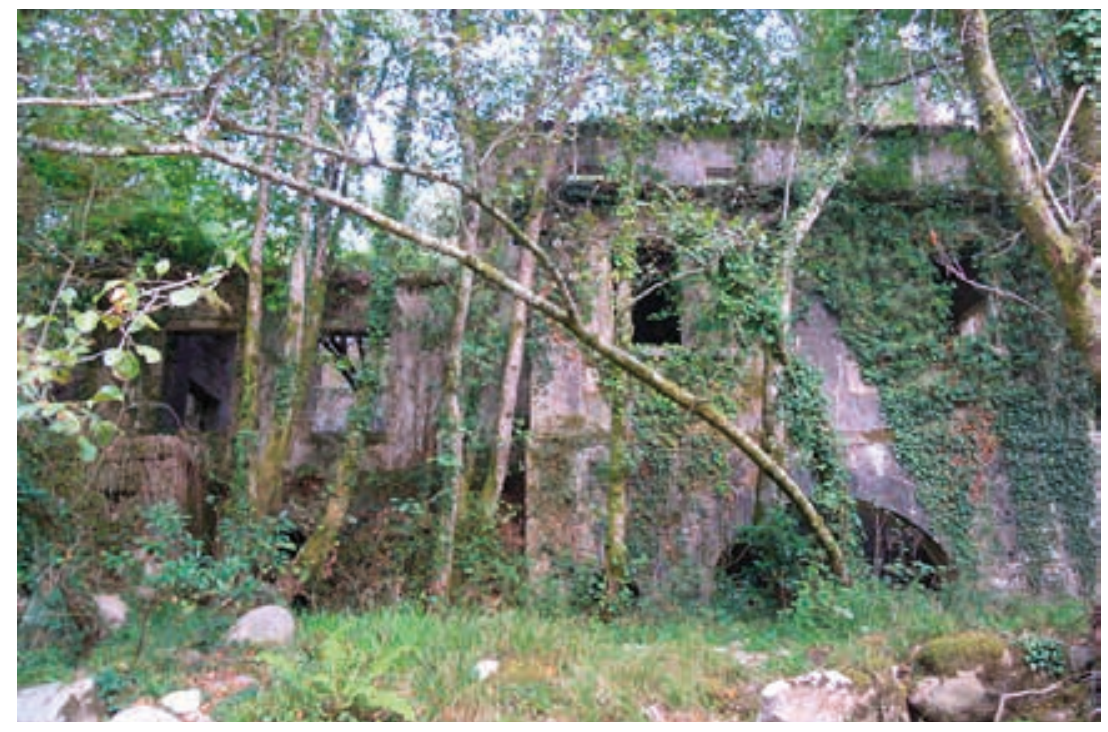

Imaxe 7. Hidroeléctrica de San Xusto no río Lérez, en Cotobade

Este conxunto de elementos patrimoniais está situado augas arriba da ponte nova de San Xusto, na marxe esquerda do río Lérez, dentro do LIC Río Lérez e da Comarca Paisaxística Baixo Lérez identificada no Catálogo das Paisaxes de Galicia. O lugar está dominado desde o alto pola carballeira e capela de San Xusto, e forma parte dun territorio no que se manifestan as pegadas das distintas fases de ocupación humana nos petróglifos do Lombo da Costa, no castro da Cividá, nos núcleos rurais e igrexas parroquiais, nos pazos e casas grandes e os seus dominios, na rede de camiños, e entre eles, na calzada empedrada que leva á ponte medieval e atravesa o Lérez.

No ano 2016, o Concello de Cerdedo-Cotobade e a Consellería de Medio Ambiente acordaron colaborar na recuperación patrimonial, etnográfica e paisaxística do conxunto que denominan Os Baños de San Xusto e a consellería redactou un proxecto desa actuación.

Sen entrar na análise do proxecto, que non é o obxecto deste comentario, é importante resaltar o cambio de enfoque que supón o tratamento conxunto dun espazo natural e dos bens patrimoniais que alberga, é dicir, o feito de pasar de ignorar o valor patrimonial deses bens a convertelos no elemento principal dun proxecto de recuperación patrimonial e paisaxística. 
Este proxecto está no camiño do obxectivo de tratar o territorio como unha paisaxe cultural, como un sistema complexo de compoñentes físicas e antrópicas dinámicas, entre as que atopamos os bens materiais que identificamos como parte do patrimonio cultural, as relacións entre eles e coas outras compoñentes materiais do territorio. Un camiño no que o territorio non só é, senón que debe seguir sendo na medida en que a sociedade constrúe, transforma ou destrúe a súa relación cos lugares. 


\section{AS FORTIFICACIÓNS MODERNAS DO RÍO MIÑO. REFLEXIÓNS SOBRE DIFERENTES ESTRATEXIAS PARA A SÚA POSTA EN VALOR}

Rebeca Blanco-Rotea

Grupo de investigación Síncrisis

(Universidade de Santiago de Compostela)

DOI: 10.17075/pvpcr.2021.009 



\section{INTRODUCIÓN. O RÍO, UNHA GUERRA, UNHA PAISAXE CULTURAL}

O río Miño é o río mais importante de Galicia. Nace no Pedregal de Irimia, na serra de Meira, no nordeste da provincia de Lugo, e desemboca no océano Atlántico, entre as poboacións da Guarda (en Galicia) e Caminha (en Portugal), percorrendo, polo tanto, practicamente toda a xeografía da comunidade galega. $\mathrm{O}$ interese por este río no presente texto vén da súa condición de fronteira natural nos seus últimos $76 \mathrm{~km}$ entre España e Portugal, un espazo coñecido como Baixo Miño en Galicia e Alto Minho no país veciño. Nós referirémonos a el cando falemos do espazo común como o val do Miño ou a fronteira miñota.

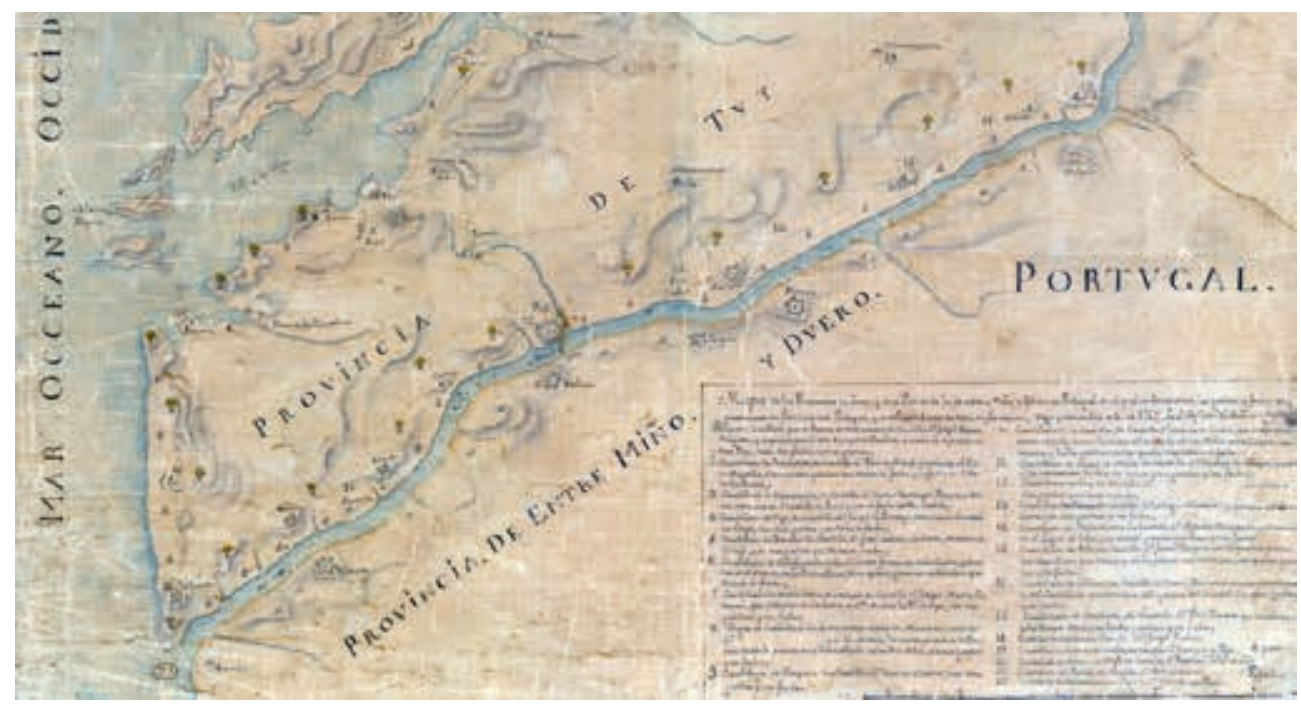

Figura 1. Mapa da antiga provincia de Tui, entre o Douro e o Miño, onde veñen sinaladas as garitas e fachos. D. Alexandro de Anglés, 1762, (C) Centro Geográfico del Ejército

Esta fronteira tivo un especial interese durante o período transcorrido entre 1640 e 1668, momento no que tivo lugar a Guerra da Restauración entre o Reino de Portugal e a Coroa de Castela, tras a proclamación como rei João IV (1640-1656) do duque de Bragança, cabeza dunha antiga familia nobre portuguesa e descendente de João I de Portugal. Con motivo deste proceso bélico, o espazo localizado no último tramo do río Miño, que contaba cunha serie de castelos e torres medievais localizadas estratexicamente nas zonas de pasos sobre 
o río, foi transformado durante a guerra e con posterioridade a ela, o que deu lugar a unha paisaxe fortificada á moderna, cuxo elemento máis significativo será a realización dunha serie de fortificacións de planta abaluartada tanto de carácter permanente coma de campaña, que, ao longo destes $76 \mathrm{~km}$, interactúa co río Miño, cos seus pasos, coas vilas e cidades que se atopan na súa beira, e coas serras que pechan o val polo norte e polo sur (figura 1). Hoxe, esta paisaxe e os elementos que a conforman constitúen un dos conxuntos patrimoniais fronteirizos máis ricos e interesantes que temos en Galicia. Neste texto, que se corresponde co relatorio impartido o día 7 de novembro de 2018 nas xornadas "A posta en valor do patrimonio cultural dos ríos: Galicia e outros exemplos», organizadas polo Consello da Cultura Galega, reflexionaremos sobre a súa relación co río, sobre a súa condución como elemento patrimonial e sobre a súa posta en valor.

\section{O ESPAZO FRONTEIRIZO DO RÍO MIÑO}

O último tramo do río Miño constitúe a fronteira hispano-portuguesa nun espazo denominado A Raia Húmida, que abarca, ademais do propio val a ambos os dous lados do Miño constituído por unha planicie aluvial, unha zona de ascenso cara a unha serie de bandas montañosas que pechan este espazo polo leste (a serra do Suído, en Galicia, e da Peneda-Gerês, en Portugal), o norte (serra do Suído, montes da Paradanta, serra do Galiñeiro, serra do Galleiro, serra do Argalo e serra da Groba), o sur (serra da Peneda, serra da Boulhosa, serra Pequena, serras da Gávea, Salgosa e Covas, e serra da Arga) e o oeste (a serra da Groba, en Galicia, e a serra da Arga, en Portugal); estas serras coinciden topograficamente coas alturas elevadas da dorsal meridiana (Santos e Santos, 1996: 385) (figura 2). O río desemboca no océano Atlántico e a súa desembocadura é un lugar de acceso cara ao interior deste espazo. Desde un punto de vista xeográfico, hai aspectos relevantes, como a topografía, que terán unha importante repercusión na conformación da paisaxe fortificada que se analiza neste texto, pois deles dependerá a selección da localización das fortificacións, a visibilidade e a visibilización entre entidades ou a facilidade de tránsito a través deste territorio. A pesar da existencia dunha división tanto física coma administrativa neste espazo, as características xeográficas presentan bastantes similitudes a ambos os lados da fronteira. Tanto 
para Galicia coma para Portugal, o río Miño constitúe o eixe vertebrador da vida neste territorio. Neste traballo, é importante a análise da relación entre o espazo físico e os elementos que se construíron durante o proceso de fortificación, pois a paisaxe non deixa de ser a interrelación entre dous fenómenos: por un lado, o puramente natural que corresponde á propia estrutura do medio e, por outro lado, o eminentemente antrópico que contribúe á transformación dese medio.

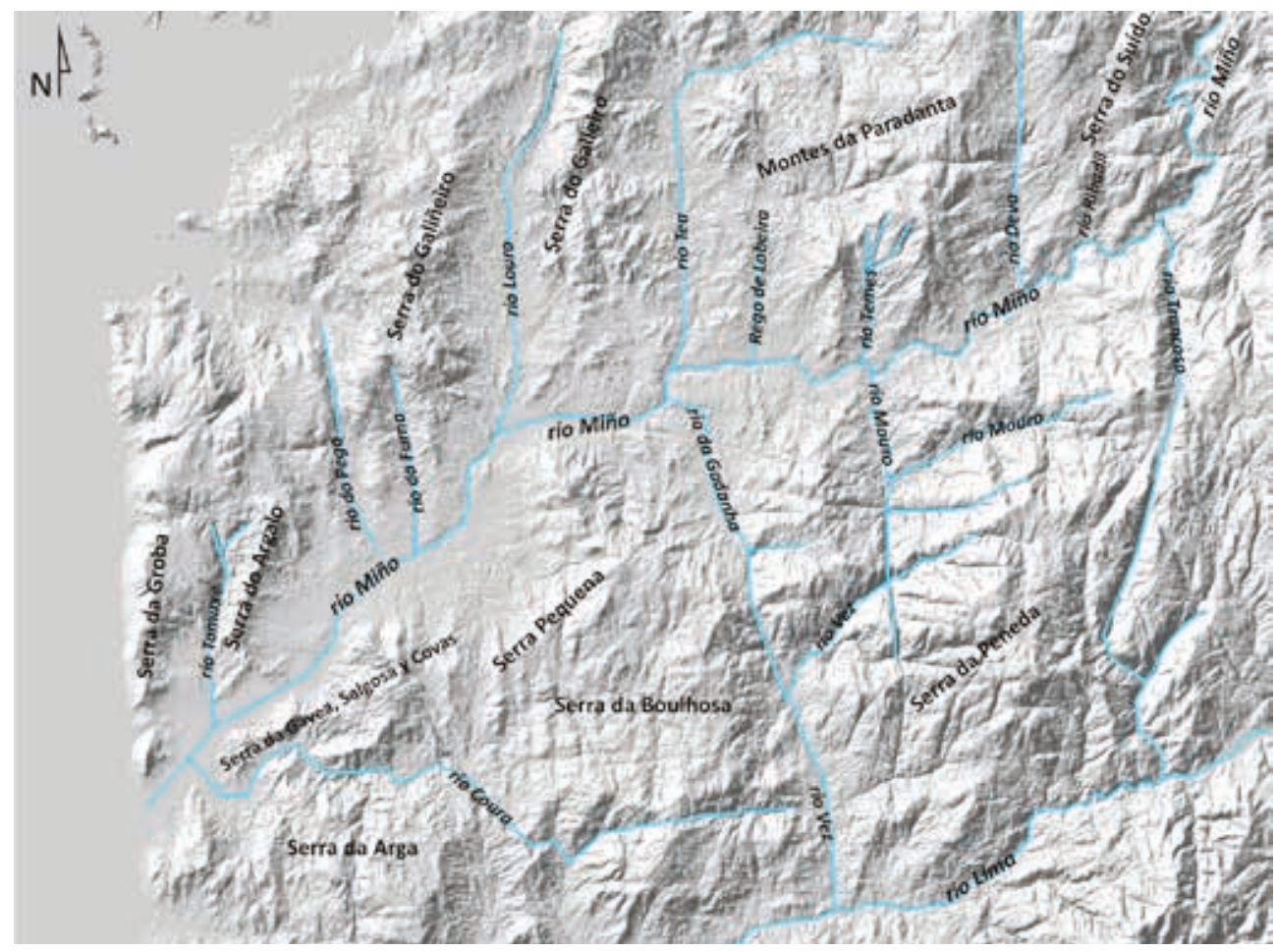

Figura 2. Modelo Dixital de Elevacións (MDE) da área de estudo Raia Húmida, coa localización das zonas montañosas e de serra, e da rede hidrográfica principal

O río Miño desemboca entre as poboacións de Caminha e A Guarda formando un amplo estuario que se caracteriza por unha importante presenza de areais que, co tempo, acaban formando pequenas illas; chama a atención a diferenza que constatamos ao comparar as cartas náuticas doutras épocas coas imaxes satélite actuais deste tramo do Miño pola variabilidade que se documenta nestas illas, aspecto que debe terse en conta xa que puido influír na variación dos pasos ao 
longo do curso baixo do río e, en consecuencia, das zonas que se debían controlar dentro del (figura 3). Este espazo conta con diversas áreas de grande importancia ecolóxica que están actualmente protexidas ${ }^{1}$. Os últimos $80 \mathrm{~km}$ do Miño, desde o embalse de Frieira, en Crecente, até a desembocadura, e algúns afluentes, como o Tea e o Tamuxe (en Galicia) e o Coura (en Portugal), están amparados en ambas as marxes dentro dun espazo transfronteirizo que pertence á Rede Natura. A orografía da zona fai que existan ademais unha serie de atalaias naturais que serviron para o control do territorio, coma o monte Santa Trega ou o Aloia, que é Parque Natural (en Galicia), e os montes Espiga, San Paio ou Gois (en Portugal), que foron ocupados como fachos desde os que prender luminarias que formarán parte da paisaxe fortificada que nos interesa.

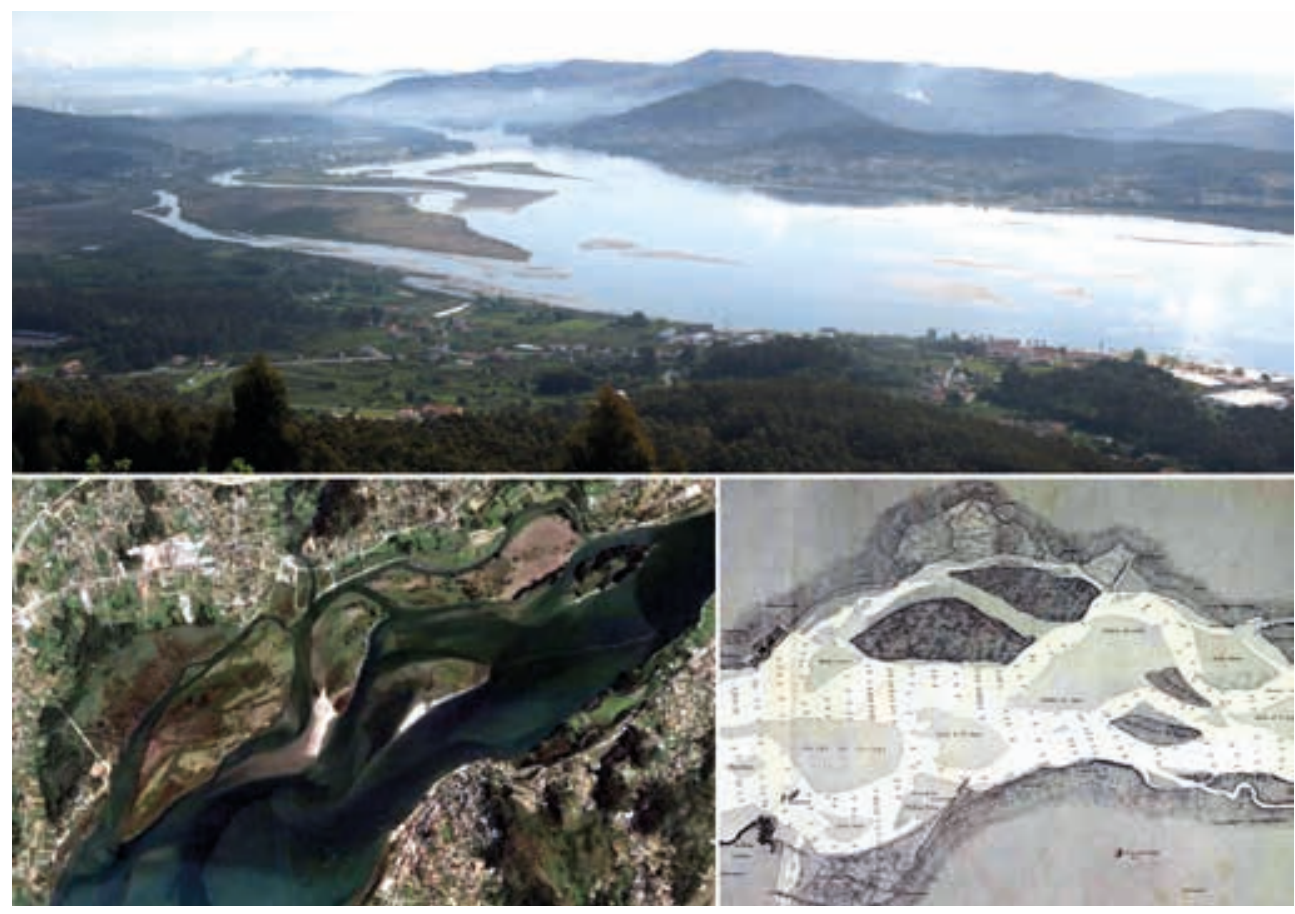

Figura 3. Areais que se forman na desembocadura do río Miño: arriba vistos desde o monte Santa Trega; abaixo á esquerda, imaxe satélite da misma zona (Google Earth 2013); á dereita, parte da Carta Náutica del Río Miño de 1885 de Rafael Sociats y Arricant (Sala Goya. Cartografía, Sede Recoletos, MR/22 H. 0901). Nestas dúas últimas imaxes, pódese observar a variación dos areais entre finais do século XIX e a actualidade

1 http://fortalezas.valedominho.pt/gl/enquadramento_ambiental.html, consulta de maio de 2011. 
O río é navegable até Valença do Minho-Tui, aínda que tamén pode chegarse a Salvaterra-Monção, como mostran as representacións de embarcacións subindo polo Miño xa desde a época baixomedieval, pero tamén as cartas náuticas que se conservan. A partir destas dúas últimas poboacións, o río estréitase e proliferan os afloramentos rochosos, ademais das pesqueiras ${ }^{2}$, discorre máis encaixado e aumentan os meandros, o que dificulta a navegabilidade. Este aspecto hai que relacionalo co cambio da orografía no tramo máis oriental do curso baixo do Miño.

O relevo do último tramo do río Miño presenta unha gran variedade e está caracterizado pola diversidade e a fragmentación (Santos e Santos, 1996: 382); é un sector no que se combinan o val do Miño, que ten unha orientación nordeste-suroeste, e os vales perpendiculares a el dos ríos Deva, Temes, Tea, Louro e Tamuxe (en Galicia), e Trancoso, Mouro, Gadanha ou Coura (en Portugal), que aproveitan precisamente esas intensas fracturas do terreo e descenden dunha serie de serras (Pérez Alberti, 1986b: 404). Neste último tramo alternan sectores que superan os 1000 metros de altitude con outros que se localizan ao nivel do mar. Pechando o val do Miño polo norte e o sur localízanse senllas bandas montañosas que corresponden a distintas serras (Pérez Alberti, 1986b: 386): no caso galego, os montes da Paradanta e as serras do Galleiro, Argalo ou Galiñeiro e, no portugués, as serras da Peneda, Boulhosa, Gávea, da Salgosa, da Cova ou da Arga; esta disposición entre cadeas montañosas fai que esta zona teña unha alta pluviosidade e nebulosidade. Ao mesmo tempo, de leste a oeste está conformada por unha sucesión de interfluvios montañosos e vales fluviais profundos ${ }^{3}$. Os primeiros teñen unha dirección norte-sur no caso galego, e sur-norte e leste-oeste no portugués, e presentan orografías elevadas con vertentes raídas que culminan en planicies descontinuas en Galicia (ib.) e en practicamente unha única planicie en Portugal, situada entre a liña de ruptura cara ao Miño das serras e o río Lima.

2 Grandes muros construídos en pedra que penetran no río desde os que se pesca a lamprea. Este tipo de construcións remóntanse polo menos á época altomedieval (Viveen, Sanjurjo-Sánchez, Goy-Diz, Veldkamp e Schoorl, 2014). Na zona estudada en Chan de Vide (As Neves), no contorno da Outal de Medáns, os sedimentos formados polas pesqueiras remóntanse ao século VIII.

3 Este tipo de relevo é característico en Galicia, onde se produce unha combinación de horizontalidade, superficie de aplanamento, e verticalidade, representada polos vales fluviais, orixinando multitude de paisaxes diferentes (Pérez Alberti, 1986a: 22). 
Os vales fluviais, aínda que profundos, son anchos co fondo aplanado (ib.); cara á zona máis oriental, os vales son cada vez máis encaixados, coma no caso do río Mouro (en Portugal). Este espazo será ocupado polos sistemas defensivos que veremos máis adiante. De feito, esta sucesión de montañas e vales van condicionar historicamente a disposición dos distintos núcleos de poboación no val do Miño, pero tamén constituirán un elemento chave na elección e distribución das fortificacións ao longo deste territorio. Estes aspectos, entre outros, serán o xermolo da construción na época moderna dunha serie de conxuntos fortificados que responden a aspectos que están moi relacionados coa existencia desta rede de poboamento previa, duns sistemas defensivos precedentes ou da propia articulación do territorio, como veremos.

\section{O ESPAZO DA GUERRA}

A fronteira histórica hispano-portuguesa deseñouse ao longo dos séculos XII e XIII, e quedou practicamente configurada desde 1297 co Tratado de Alcañices. Desde época temperá, a realeza buscou puntos de apoio para a súa estratexia de empoderamento político-administrativo (Andrade, 1998), incentivando a construción de núcleos de poboación nas marxes do río Miño, que constituía unha importante vía fluvial de penetración cara ao interior de ambos os dous reinos desde o océano (en sentido oeste-leste), do mesmo modo que, en paralelo a este por ambas as súas marxes, circulaba unha vía terrestre que unía as principais poboacións agora consolidadas. Pola súa vez, existen outras vías que atravesan o territorio en sentido norte-sur salvando o río Miño a través dos pasos de barcas (Almeida, 1968; Almeida, 1984; Andrade, 1994: 271-274). É precisamente nas zonas nas que se localizan estes pasos xa históricos (Ferreira, 1988; Andrade, 1994: 274) onde foron xurdindo os núcleos de poboación máis importantes da fronteira ao longo da Idade Media, que foron fortificados nos séculos XII e XIII. De aí a presenza de poboacións enfrontadas a un e outro lado da fronteira que se irán consolidando co tempo, amurallándose ou construíndo nelas un castelo propiedade do monarca, ou dominando a rede viaria que ordenaba a rexión (Andrade, 1994: 329). Iníciase así a fortificación da Raia. A este momento pertencen núcleos como Caminha, Valença ou Melgaço (en Portugal) ou Tui e Salvaterra 
(en Galicia) (Pallares, 1987; Pallares e Portela, 2015: 140). Esta paisaxe defensiva concentrábase nos núcleos de poboación situados en zonas de paso sobre o río Miño, condicionando a estrutura defensiva que se desenvolveu en época moderna, cando a fortificación anterior era insuficiente ante os avances da artillaría e a nova articulación dos exércitos da época (Parker, 2002).

A Guerra da Restauração ten lugar entre o 1 de decembro de 1640, cando o duque de Bragança é proclamado en Lisboa rei de Portugal como João IV, e o ano 1668, cando se firma o Tratado de Lisboa, que supuxo a independencia de Portugal, reino anexionado ao Imperio Hispánico desde 1580 por Filipe II. O 1 de decembro, devolve a nación lusitana a estado primitivo e restáurase a súa condición de reino per se (Silva, 1862: 3; Bouza, 1991, 1993; Almeida, 2013).

Entre 1640 e 1668, as campañas de guerra foron descontinuas espacial e temporalmente, e dependían das dispoñibilidades loxísticas de persoal e material. Foi unha guerra con escasos medios e especialistas, cunha grande importancia táctica da artillaría, as armas de infantaría e os enxeñeiros, na que exerceu un especial papel a construción dunha serie de fortificacións abaluartadas sobre todo de campaña (Costa, 2005; CADIVAFOR, 2008: 8; Almeida, 2013). A actividade bélica foi acompañada dunha importante actividade construtiva grazas á modernización das defensas de ambas as dúas frontes, a toma de posicións no país contrario e a importante transformación da arquitectura e a paisaxe precedentes. Se ben é certo que, nos grandes núcleos urbanos que xa contaban cunhas defensas previas, a actividade é case constante desde o inicio da guerra, naqueles lugares onde as fortificacións se realizan ex novo neste momento, a actividade construtiva coincide con episodios concretos da contenda que afectan a zonas determinadas. Por exemplo, os galegos ocupan o contorno de Salvaterra con fortificacións de campaña unha vez conquistada a vila polos portugueses e iniciada por eles a súa modernización: neste caso teriamos un castelo medieval que se abaluartúa neste momento e a construción ex novo dunha defensa de campaña por parte do exército galego para cortarlles o paso aos portugueses de cara a Tui.

Cando, en 1668, se firma o Tratado de Paz de Lisboa, Portugal alcanza a súa independencia e establécense as fronteiras que se manteñen practicamente intactas até a actualidade. Cada país devolve ao outro as prazas conquistadas no territorio veciño, pero a modernización defensiva das cidades continúa e as fortificacións permanentes finalízanse ao longo dos séculos XVII e XVIII. 


\section{A PAISAXE FORTIFICADA}

O concepto de paisaxe manexado neste texto compréndea como a interrelación entre dous fenómenos, un puramente natural que corresponde á propia estrutura do medio e outro eminentemente antrópico que contribúe á transformación e obxectivación dese medio (Criado-Boado, 1999: 5). Este concepto recolle as recomendacións do Convenio Europeo da Paisaxe que a entende como «calquera parte do territorio tal como a percibe a poboación, cuxo carácter sexa o resultado da acción e a interacción de factores naturais e/ou humanos». O debate sobre a evolución deste concepto desde a arqueoloxía foi amplamente tratado por outros autores (Wittlesey, 1997; Knapp e Ashmore, 1999: 8-13; Criado-Boado, 1999: 5-6; Anschuetz, Wilshusen e Scheick, 2001: 160-168; Heilen, 2005: 14-39). No noso caso, propuxemos unha tripla conceptualización, entendendo a paisaxe como a materialización dun concepto resultado dun proceso e recurso do pasado no presente (Blanco-Rotea, 2017). Esta conceptualización está baseada na matriz empregada por Criado-Boado que representa a ontoloxía do Patrimonio Arqueolóxico nas súas tres dimensións como documento (do pasado), como obxecto (do pasado no presente) e como recurso (no presente) (Criado-Boado, 2012: 193-194), pero tamén no paradigma de paisaxe de Anschuetz, Wilshusen e Scheick (2001) rexido por catro premisas:

1. Landscapes are not synonymous with natural environments. [...] 2. Landscapes are worlds of cultural product. [...] 3. Landscapes are the arena for all of a community's activities. [...] 4. Landscapes are dynamic constructions, with each community and each generation imposing its own cognitive map on an anthropogenic world of interconnected morphology, arrangement, and coherent meaning. (Anschuetz, Wilshusen e Scheick, 2001: 160-161)

A partir deste marco teórico, determináronse aqueles conceptos que serán a base da nosa investigación sobre a paisaxe fortificada da fronteira en época moderna ${ }^{4}$.

4 Estes conceptos foron definidos na tese de doutoramento da autora (Blanco-Rotea 2015) e recollidos en Blanco-Rotea, 2017. 
A paisaxe fortificada defínese como unha paisaxe cultural na que se insire algún tipo de arquitectura cuxa organización responde a unha estratexia defensiva concreta, polo que se organiza ou articula nun ou varios sistemas defensivos. O Plan Nacional de Arquitectura Defensiva Español ${ }^{5}$ considera que «A arquitectura defensiva forma parte indisoluble da paisaxe cultural na que se insire e á que caracteriza. Os elementos que compoñen esta arquitectura están relacionados entre si dentro desa paisaxe e, en consecuencia, deberán ser tratados como agrupacións completas de sistemas xerais defensivos, con metodoloxía similar». Segundo esta definición, paisaxe fortificada e arquitectura defensiva deben entenderse de forma conxunta e analizarse de forma conxunta, sendo necesario desenvolver programas de investigación e propostas metodolóxicas que atendan ambas como parte dunha mesma realidade.

A arquitectura implántase nun espazo físico ao que articula, conformando unha paisaxe na que se materializan as formas de pensamento da sociedade que executa esa arquitectura, no noso caso, os principios da fortificación abaluartada ${ }^{6}$ e a lóxica barroca. No entanto, pola súa vez, a arquitectura debe adaptarse ao medio físico. Os principios da fortificación abaluartada deberán adaptarse ao lugar no que se implanta cada fortificación, serán tidos en conta na relación que se establece entre a fortificación e o espazo físico, e entre a fortificación e outras arquitecturas que poden formar parte do mesmo sistema defensivo (Matos, 2016: 35-36).

O sistema defensivo analizado nesta investigación baséase na articulación e control de distintas unidades territoriais (figura 4) denominadas subsistemas ou conxuntos defensivos ${ }^{7}$ (Blanco-Rotea, 2011b). A nosa formulación parte da hipótese de que nelas a defensa funciona como un organismo autónomo pero conectado a través de determinados mecanismos ${ }^{8}$ cos subsistemas contiguos, de maneira que os subsistemas acaban formando parte dunha estrutura maior: o

\footnotetext{
http://www.mecd.gob.es/planes-nacionales/eu/enlaces/plan-nacional-arquitectura-defensiva.html

6 Fernández de Medrano, 1700; Lucuze, 1772.

7 Sobre os conceptos de sistema e subsistema xa argumentamos en Blanco-Rotea, 2011b: 148-149. Para ampliar o modelo conceptual da paisaxe fortificada do Miño no que se explican e definen todas as entidades arqueolóxicas que o conforman, véxase Blanco-Rotea, 2015: 146-157. Sobre outras definicións e conceptualizacións de sistemas defensivos, véxase Cobos, 2005 e Cobos-Guerra, 2011.

8 Como as estructuras de relación, aquelas que comunican dúas entidades arqueolóxicas (fortificacións el ou subsistemas) entre as que non existe unha relación de visibilidade directa. Unha estrutura de relación sería, por exemplo, un facho (Blanco-Rotea, 2015: 149-150).
} 
sistema defensivo do río Miño, que formaría parte dun sistema defensivo máis complexo que engloba toda a fronteira hispano-portuguesa. Con todo, a zona que nos ocupa presenta as súas propias características, motivadas pola presenza do río Miño, a configuración xeográfica do val e a articulación histórica das poboacións da fronteira, situadas onde se localizan os pasos de barca.

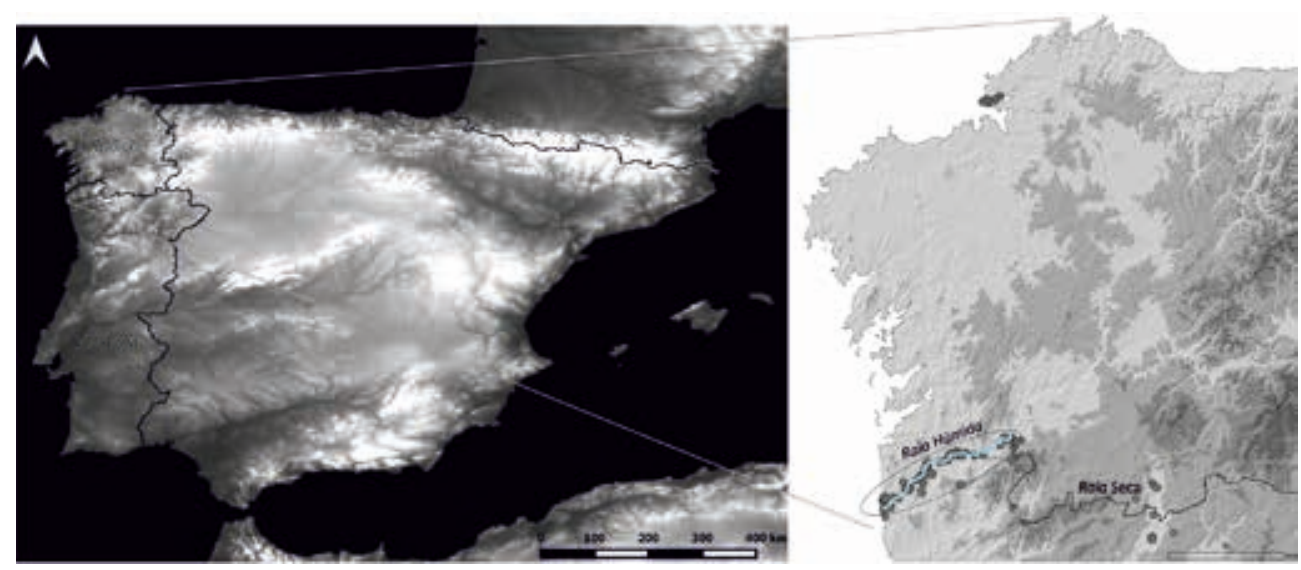

Figura 4. Localización da zona analizada neste texto. Á esquerda, mapa da Península Ibérica (STRM 90 CGIAR-CSI, elaborado por José Costa), no que se destacan Portugal e Galicia. Á dereita, mapa de Galicia coa diferenciación da fronteira galaico-portuguesa; marcouse a zona miñota en azul

En concreto, a paisaxe fortificada miñota confórmase como a suma de oito conxuntos defensivos (figura 5) que aglutinan unha serie de fortificacións, vías de tránsito, pasos de barcas e estruturas de control do territorio, e do espazo físico cruzado polo río Miño. Este río é un elemento transversal á paisaxe analizada co que se relacionan todos os conxuntos ou subsistemas de forma directa excepto o de Extremo (Arcos de Valdevez), situado entre as serras da Boulhosa e da Peneda, que se relaciona con eles de forma indirecta 9 . A maior parte dos conxuntos articúlanse con base en dúas poboacións enfrontadas, situadas en ambas as marxes

9 Esta configuración resulta do estudo realizado pola autora con motivo do desenvolvemento da súa tese de doutoramento. Hoxe en día, grazas aos traballos desenvolvidos a través dunha Axuda de apoio á etapa de formación posdoutoral do Sistema de I+D+i galego (Modalidade A, Convocatoria 2016), dentro do Grupo de Investigación Síncrisis da USC, sabemos que este sistema é mais complexo aínda e que, no caso de Extremo, existe un maior número de elementos que forman parte deste subsistema e que posibilitan esta interconexión con outros subsistemas e co propio río Miño. 
do río. Ademais, localízanse en nós viarios, en relación coa vía fluvial que supón o Miño, as vías terrestres que discorren paralelas a este e os pasos de barca, pero tamén as vías terrestres perpendiculares ao Miño que o comunican co interior dos respectivos países, coma no caso do conxunto de Extremo.

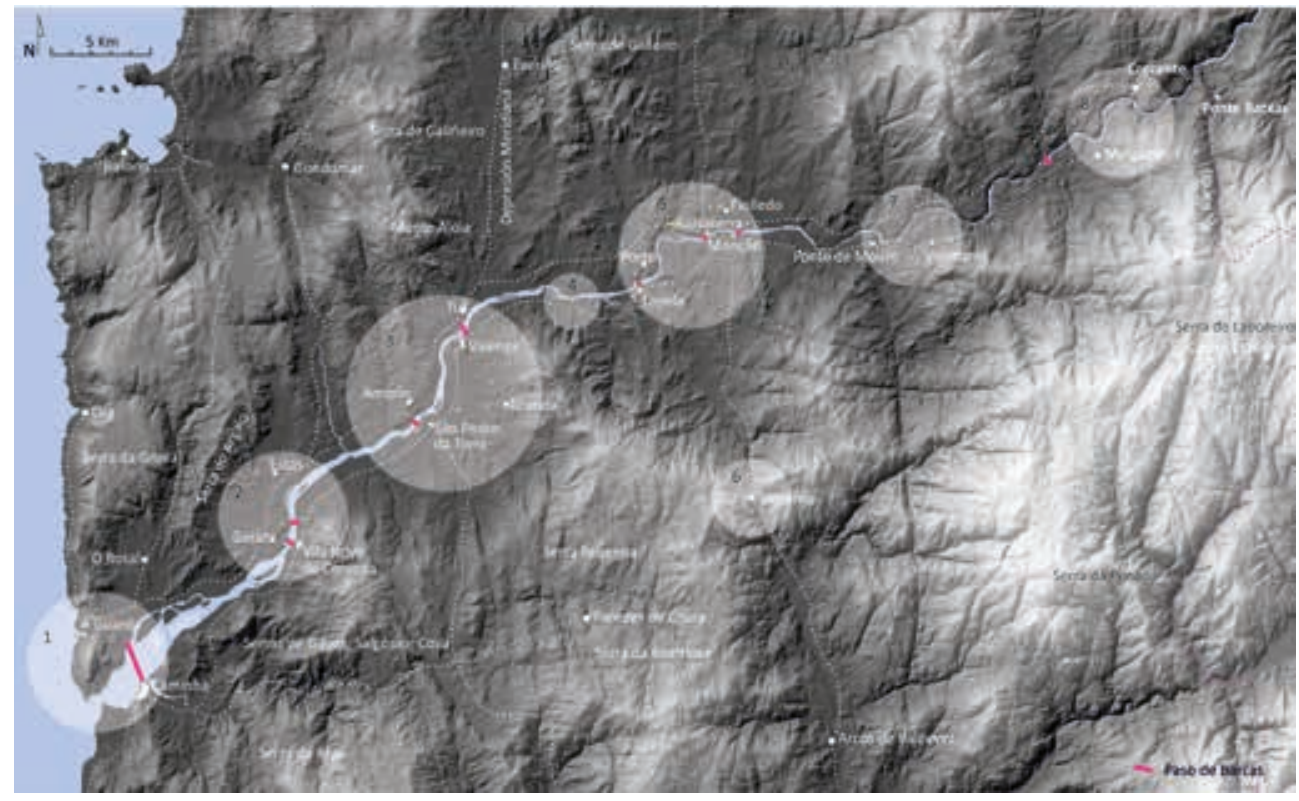

Figura 5. MDE da fronteira miñota ou Raia Húmida. Nesta imaxe, pódese observar a estrutura do territorio, percorrido polo río Miño de nordeste a suroeste formando unha planicie aluvial en ambas as dúas marxes pechada polas cadeas montañosas polo norte e o sur. En liña de puntos de cor branco, marcáronse as principais vías de tránsito terrestres. En maxenta, os pasos de barcas. Dentro dos círculos, sitúanse os subsistemas identificados: 1. Subsistema A Guarda-A Ínsua-Caminha; 2. Subsistema Goián-Vila Nova de Cerveira-Estás; 3. Subsistema Amorín-Tui-São Pedro da Torre-Valença; 4. Subsistema de Verdoejo; 5. Subsistema Salvaterra de Miño-Monção; 6. Subsistema de Extremo; 7. Subsistema de Ponte de Mouro-Valadares; 8. Subsistema Melgaço-Crecente

Cada subsistema, pola súa vez, relaciónase coa unidade territorial na que se sitúa. Na figura 6 , podemos observar a cunca fisiográfica na que se localizan as poboacións de Goián, Vila Nova de Cerveira e Estás, pechada ao norte pola serra do Argalo e ao leste-suroeste polas serras de Gávea, Salgosa e Cova, de xeito que o conxunto que conforman as fortificacións das poboacións e as súas contornas se sitúa de tal maneira que controla todo este espazo. Por outra parte, os conxuntos manteñen unha relación visual e espacial co conxunto precedente e o seguinte 
mediante fachos ou pequenos postos de vixilancia situados en altura, de forma que o control do territorio se estende á totalidade da paisaxe.

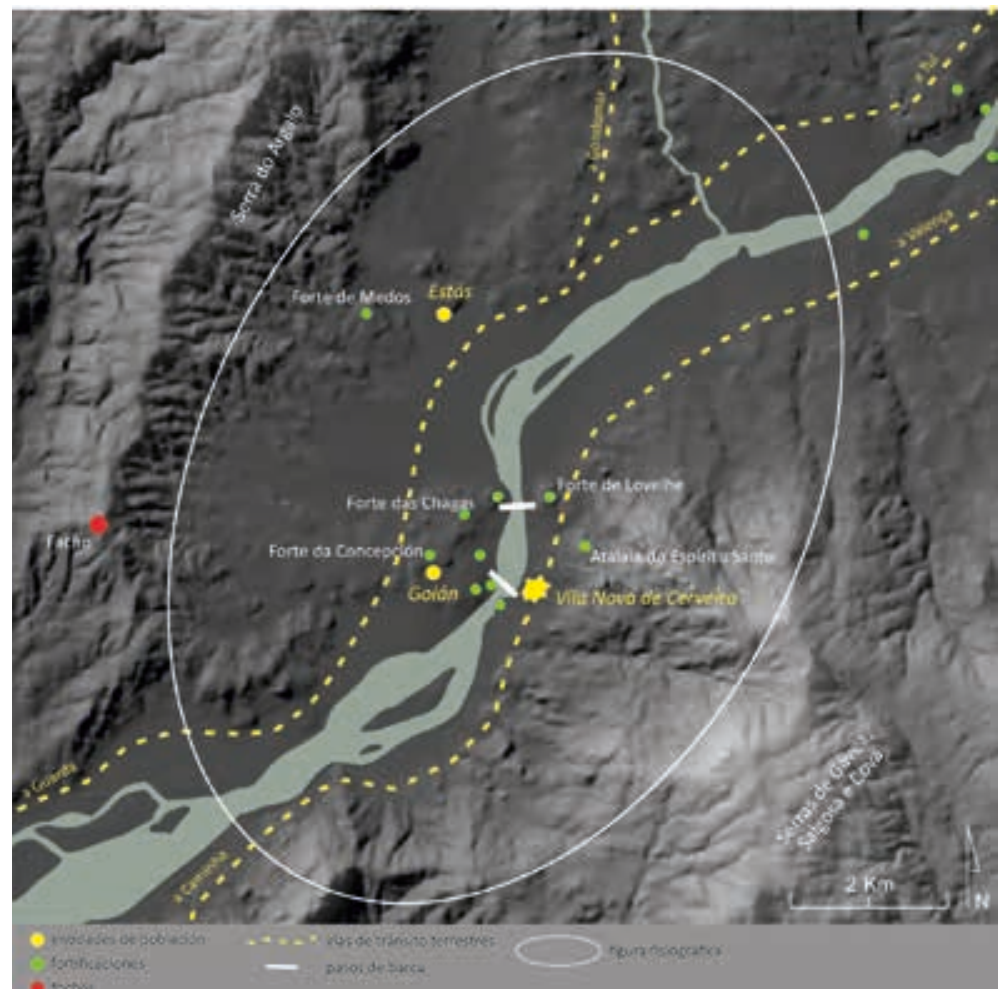

Figura 6. MDE da zona na que se localiza o subsistema Goián-Vila Nova de Cerveira-Estás. O facho situado na serra do Argalo permite comunicar visualmente este sistema e o da Guarda-A Ínsua-Caminha, situado ao OSO. As poboacións de Goián e Vila Nova de Cerveira sitúanse nunha zona de paso, tanto terrestre coma fluvial

En definitiva, os aspectos que caracterizan a paisaxe defensiva miñota son:

- $\mathrm{Na}$ fronteira galego-portuguesa conviven dous modelos de fortificación, un medieval e outro de época moderna, que se conservan de maneira moi diferente nos distintos espazos analizados, sobre todo os núcleos urbanos.

- Os conxuntos defensivos modernos situados na Raia organízanse arredor dunha poboación principal localizada a cada lado da fronteira que adoita ter unha estrutura urbana encerrada, envolta e protexida por un sistema defensivo. 
- Existen outros conxuntos que defenden as vías de comunicación que enlazan os espazos de fronteira co interior de cada un dos países que forman parte do sistema defensivo global.

- Todos estes conxuntos forman parte dun sistema defensivo moi complexo que aínda non coñecemos na súa totalidade e que se foi construíndo a medida que avanzaba a Guerra da Restauração.

\section{A POSTA EN VALOR DA PAISAXE FORTIFICADA MODERNA DO RÍO MIÑO}

As xornadas "A posta en valor do patrimonio cultural dos ríos: Galicia e outros exemplos», organizadas polo Consello da Cultura Galega, tiñan un dobre obxectivo: por unha parte, pór a mirada sobre o patrimonio cultural que está asociado aos ríos e, por outra, recoller unha lectura ecolóxica do territorio a partir dos espazos naturais e a súa conexión por corredores fluviais e infraestruturas verdes, que introduciu unha nova dimensión precisamente a ese patrimonio cultural dos ríos, onde se veñen levando a cabo interesantes experiencias necesarias para a protección e rehabilitación deste patrimonio cultural, e que contribúen á súa posta en valor desde distintas iniciativas. Precisamente, o caso do estudo da paisaxe defensiva do Miño fronteirizo, dos elementos que integran esa paisaxe e da súa interrelación co patrimonio constitúen unha destas experiencias levadas a cabo, neste caso nun espazo internacional. Para mostrar os principios desta posta en valor no caso que nos ocupa, por unha parte, empregamos o concepto de Cadea de Valor do Patrimonio Cultural (en diante, CVPC), por outra, partimos de tres preguntas.

\section{A CADEA DE VALOR DO PATRIMONIO CULTURAL APLICADA Á PAISAXE FORTIFICADA MODERNA DO RÍO MIÑO}

A Cadea de Valor do Patrimonio Cultural aplicada á arqueoloxía foi desenvolvida inicialmente por Felipe Criado-Boado (Criado-Boado, 1996a: 27-30 e 1996b) baixo o concepto de cadea interpretativa e recollida posteriormente por Matilde González Méndez na súa tese de doutoramento (González, 1999: 17-23). 
Será posteriormente cando se lle outorgue esta nova denominación como CVPC (Amado, Barreiro, Criado-Boado e Martínez López, 2002) porque se considera que «é máis acertado o concepto de cadea valorativa ou cadea de valor porque no proceso [...] entran en xogo diferentes estratexias para a produción de coñecemento, non só a interpretación» (Barreiro, 2009: 10).

A aplicación da CVPC xorde ante a necesidade de deseñar unha estratexia de revalorización do patrimonio que tome posicións «a favor da súa conversión nun recurso para o desenvolvemento económico e cultural» (Barreiro, 2009: 10) sen perder os valores que durante o proceso de revalorización se van engadindo sobre o patrimonio e van evitando que se «cousifique».

Articúlase nunha serie de fases ou instancias valorativas que constitúen os distintos elos da cadea: identificación, documentación, significación, valoración, conservación, posta en valor e recepción (figura 7). En cada unha destas instancias valorativas, aplícanse distintas estratexias de produción de coñecemento que van xerando un efecto de incremento na seguinte instancia e un valor engadido (Barreiro, 2009: 10). Este proceso de revalorización aplicado de forma sistemática fai que, en todas as fases da cadea, incluso nas últimas que implican a reversión social do patrimonio, os bens manteñan todos os seus valores.

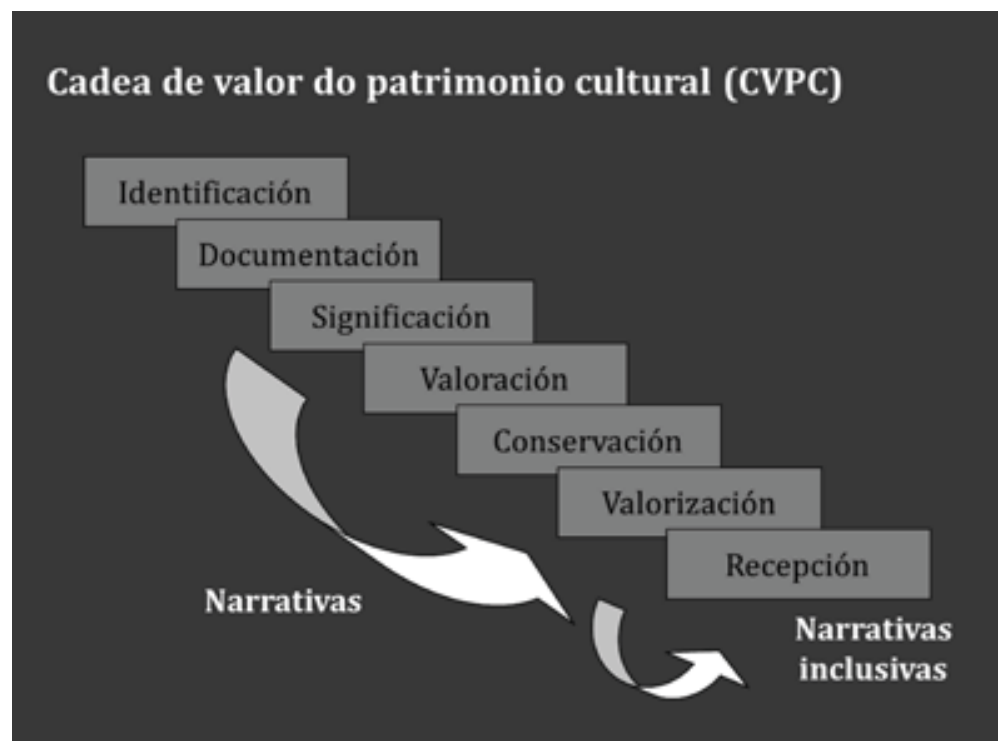

Figura 7. Representación das distintas instancias da CVPC (fonte orixinal: Felipe Criado-Boado) 
Poderiamos dicir que a CVPC consta de tres grandes fases nas que se aglutinan estas instancias: a valoración, a avaliación e a revalorización (Criado-Boado, 1996b: 76-77). A primeira delas é a práctica interpretativa que intenta estimar o valor orixinal dun elemento histórico; é unha práctica teórica que xera unha representación do modelo descritivo e interpretativo sobre unha entidade ou grupo de entidades (Criado-Boado, 1996b: 76). No caso das entidades arqueolóxicas, unha valoración arqueolóxica é dúas cousas ao mesmo tempo: unha reconstrución do valor orixinal e un recoñecemento do seu valor actual. A segunda, a avaliación ou valoración patrimonial, é a práctica interpretativa que intenta calcular o valor patrimonial dun elemento histórico desde un punto de vista patrimonial; é unha práctica teórica que xera un modelo de xestión, protección e/ou revalorización da entidade ou grupo de entidades analizados. Converte o documento histórico en patrimonio histórico, a entidade arqueolóxica en patrimonio arqueolóxico (Criado-Boado, 1996b: 76). Finalmente, a revalorización é unha práctica interpretativa que converte o patrimonio histórico en bens; constitúe unha práctica teórica que xera unha alternativa que posibilita unha rendibilidade sociocultural dese elemento. Os seus resultados poden ser de tipo material (unha actuación física sobre un obxecto) e inmaterial (un argumento que dote de sentido un obxecto) (Criado-Boado, 1996b: 76-77). En relación con estes resultados, Criado-Boado diferencia dous tipos distintos de prácticas de revalorización: a rendibilidade, que sería a forma de revalorizar un elemento arqueolóxico a través dunha acción intanxible dotando meramente ese elemento dun argumento (no noso caso, a construción dun discurso histórico a través da valorización dos elementos que forman parte da paisaxe fortificada da Raia miñota, e que recupere a súa memoria esquecida), e a rehabilitación, que sería a acción física sobre el (unha vez valorizados e avaliados os bens, serán revalorizados mediante unha acción que os recupere fisicamente, por exemplo mediante a limpeza, escavación e restauración deses mesmos bens). 


\section{TRES PREGUNTAS}

\section{Canto tempo é necesario para que perdamos a memoria histórica do noso patrimonio?}

Cando comezamos a traballar no ano 2003 no contexto da redacción do plan director (en diante, PD) FORTRANS (Cobos e Hoyuela, 2005; Vecoña, 2006) na zona do Baixo Miño, a situación do forte de Santa Cruz, na vila da Guarda, era a que reflicte a imaxe que mostramos na figura 8 , un elemento practicamente oculto aos ollos da veciñanza, cuberto de árbores, no que se comezaba a rozar o exterior do cuadrante O-N-E con motivo dun plan urbanístico aprobado na súa contorna. Resultaba de especial interese para o noso proxecto descubrir para os que eramos foráneos da vila a presenza dunha fortificación que fora practicamente invisibilizada e eliminada da memoria de moitos veciños e veciñas, e que, non obstante, era unha das de maior envergadura deste lado da fronteira, de carácter permanente (realizado en pedra) e nun estado de conservación en bastante mellor situación ca noutros casos analizados.

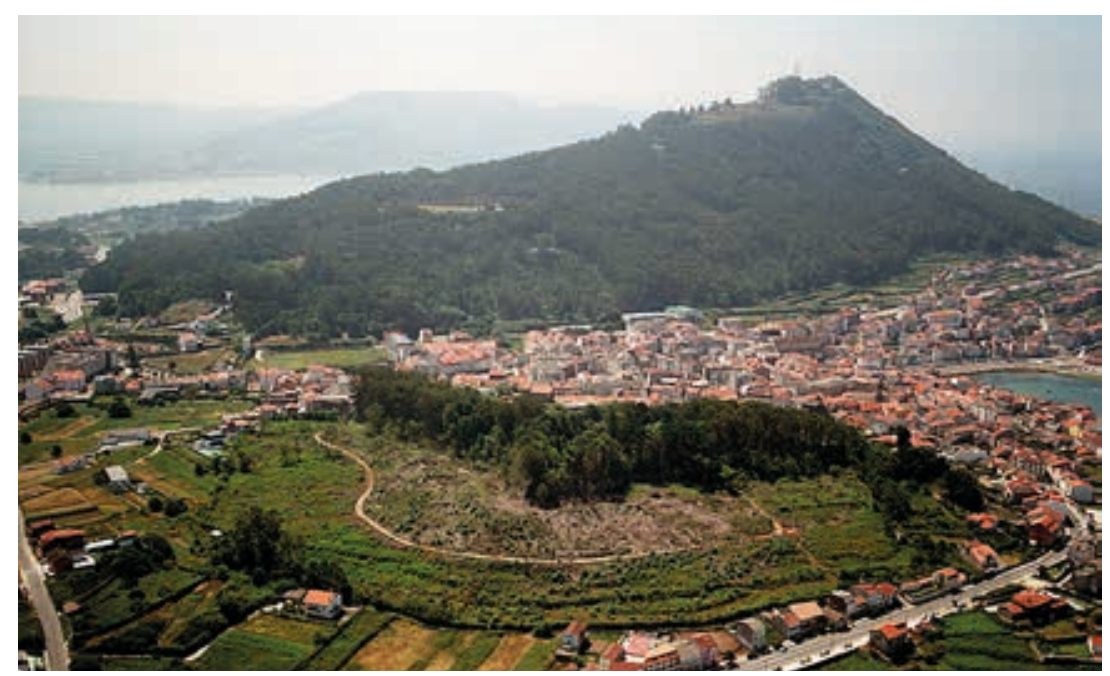

Figura 8. Vista aérea da vila da Guarda (Fonte: Paisajes Españoles S. A., 2001). Na parte central da imaxe, nun pequeno outeiro que domina a vila construída ao redor dunha pequena enseada, localízase o forte de Santa Cruz ${ }^{10}$

${ }^{10}$ Coñecido popularmente como castelo de Santa Cruz. 
Porén, a imaxe que existía dela a través das fotografías históricas que conservaba, entre outros, o veciño Antonio Martínez Vicente, perdérase na memoria en menos dun século, cando, a partir da venda por parcelas do forte de Santa Cruz a distintos propietarios en 1860, se inicia a súa transformación: un dos novos donos, Ángel González Sobrino, restaura as murallas e destina parte do recinto a recreo e cultivo; tamén se construirá, pegada á súa muralla polo exterior, unha fábrica de embutidos e, no interior, a fábrica de cerámica Santa Cruz, provedora da Casa Real, propiedade de D. Juan A. Lomba Álvarez (Garrido, 2004).

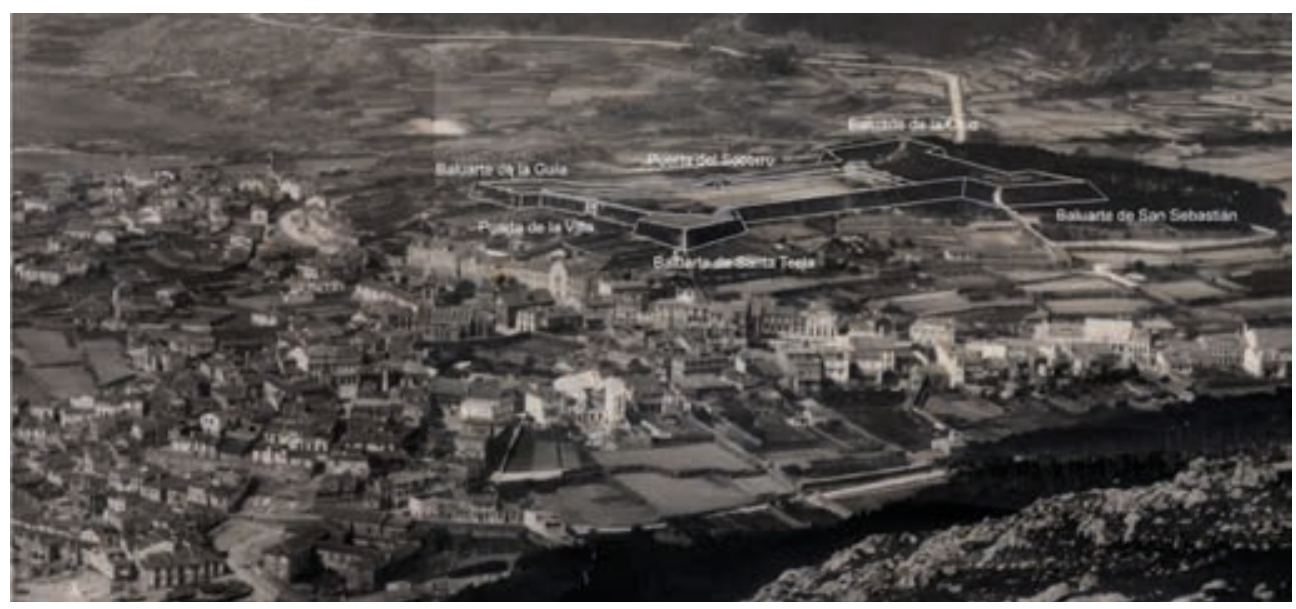

Figura 9. Forte de Santa Cruz na primeira metade do século xx (fotografía propiedade de Antonio Martínez Vicente). Nela, debuxamos o volume do forte e indicamos as súas partes principais

Como resultado desta transformación, engadíronse ao longo das seguintes décadas unha serie de predios particulares na fronte suroeste que ocultaban parte do perímetro do forte. Unicamente o acceso á Porta da Vila, principal entrada á fortificación, se respectou deixando un camiño que discorre entre predios particulares e os seus muros de peche. $\mathrm{O}$ mesmo sucedeu na súa fronte sueste, ocupada por grandes predios particulares. Os muros que as delimitan morren, respectivamente, no ángulo capital dos baluartes de Santa Trega e San Sebastián. O seu interior foi ocupado por unha gran cantidade de vexetación arbustiva que oculta este fronte á vista. O mesmo fenómeno sucedeu no interior do castelo, onde tamén se desenvolvera un frondoso xardín con abundante vexetación e se construíran varias estruturas. Todos estes elementos facían que esta peza da fortifi- 
cación abaluartada fronteiriza fose pouco a pouco ocultándose no pasado recente da vila até chegar a invisibilizarse na súa memoria. Ese proceso, en certo modo, foi revertido cos traballos vencellados á redacción do PD (figura 9).
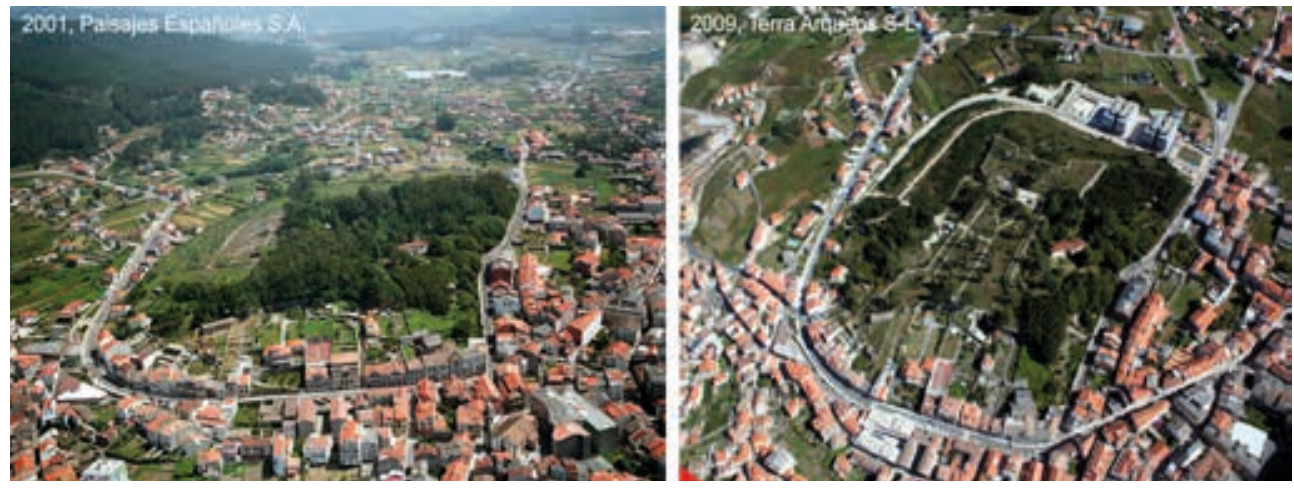

Figura 10. Nos últimos anos, levouse a cabo un proxecto de recuperación do forte que incluía a adquisición por parte das administracións públicas, a corta da vexetación interior e exterior, a restauración dos elementos construtivos e a recuperación dunha das edificacións interiores como lugar expositivo. Porén, xorde tamén un novo proceso de invisibilización parcial da fortaleza a raíz da urbanización da súa contorna. Na imaxe da dereita, pódense ver as torres construídas

Cando comezou o desenvolvemento do PD FORTRANS, existía, como comentamos, un plan urbanístico xa aprobado para a contorna do forte, que suporía a súa urbanización coa construción de pistas e varios edificios de vivenda de gran porte sobre a súa explanada exterior, elemento que forma parte del e ten un papel fundamental para a súa comprensión. A pesar dos resultados dos estudos previos, este plan seguiu adiante. Hoxe levouse a cabo parcialmente e construíronse dúas das torres de vivendas proxectadas, o que motivou unha nova invisibilización parcial do castelo, que, en función da localización da persoa que o mira, pode quedar totalmente oculto se observamos, por exemplo, A Guarda desde o río Miño ou cando se accede á vila desde o nordeste (figura 9).

\section{Como podemos recuperar esa memoria?}

O traballo arqueolóxico realizado, primeiro, no contexto do estudo do PD FORTRANS (Blanco-Rotea, 2009) e, logo, na elaboración da tese de doutoramento da autora (Blanco-Rotea, 2015) está baseado no emprego da CVPC como ferramenta hermenéutica. Desde ela, preténdese converter o patrimonio 
arqueolóxico nun recurso para o desenvolvemento económico e cultural, pero antes haberá que dotalo de contido, sendo tres, como vimos, as grandes fases para conseguilo: a valoración do ben (proceso de identificación, documentación, significación e valoración dos bens que integran a paisaxe fortificada miñota), a avaliación (proceso de conservación e valoración desa paisaxe) e a revalorización (proceso de posta en valor e recepción desa paisaxe). Para desenvolver estas fases, deseñamos un método de traballo que pasa por analizar as paisaxes nas súas distintas escalas de significación (microespacial, semi-microespacial e macroespacial), intentando identificar, documentar e comprender a materialidade e, con ela, os valores que están detrás de cada un dos elementos que durante a Guerra da Restauração portuguesa se construíron no territorio miñoto, como fortalezas, plataformas, baterías, atalaias, fachos, pasos de barcas, vías... (escala microespacial); as relacións que estes elementos gardan entre si formando conxuntos defensivos ou subsistemas (escala semi-microespacial), e, finalmente, as relacións entre estes e o territorio, o que deu lugar a unha paisaxe fortificada complexa (escala macroespacial). Así, podiamos reconstruír aquela paisaxe esquecida, valorizala e logo socializala mediante mecanismos que integrasen as comunidades locais.

Aínda que xa temos comentado esa metodoloxía en traballos anteriores (Blanco-Rotea, 2008, 2011a, 2018), expoñemos aquí os seus pasos principais ${ }^{11}$ :

- Estudo das fontes documentais e bibliográficas.

- Análise de documentos gráficos e superposición destes documentos sobre fotografías aéreas e satélite actuais.

- Identificación de elementos fortificados:

- Prospección aérea mediante fotointerpretación e análises de datos LiDAR (Light Detection and Ranging) (Jones, 2010).

- Prospección arqueolóxica dos cascos históricos e as súas contornas (Blanco-Rotea, 2011a: 187-190), así como das marxes do río Miño, especialmente nas zonas onde se localizaban os pasos de barca históricos.

- Caracterización dos elementos fortificados:

○ No caso dos espazos urbanos e das fortificacións permanentes:

11 Se se quere revisar a súa aplicación a unha paisaxe fortificada urbana, véxase Blanco-Rotea, 2018, concretamente a figura 4 , onde se mostra o proceso de análise da paisaxe urbana fortificada da cidade de Tui. 
- Análise de corpos de fábrica (Quirós e Gobbato, 2004: 193): diferenciación de grandes volumes con homoxeneidade funcional e estratigráfica.

- Lectura das fábricas (Caballero, 1995): diferenciación de fases construtivas.

- No caso dos espazos non urbanos e das fortificacións de campaña:

- Análise formal dos elementos identificados.

- Definición e caracterización da planta.

- Xeorreferenciación dos datos no Google Earth e baleirado nun SIX (sistema de información xeográfica) (Lock e Stancic, 1995).

- Construción dos MDE (modelos dixitais de elevacións) (Wheatley e Gillings, 1999).

- Análise de visibilidade (Wheatley, 1995) e de mobilidade (Llobera, Fábrega-Álvarez e Parcero-Oubiña, 2011).

- Caracterización da paisaxe (sistema).

- Clasificación dos elementos que compoñen a paisaxe (subsistemas).

- Construción de modelos teóricos.

- Procesos de posta en valor da paisaxe e dos elementos que a integran.

- Análise da recepción desta paisaxe por parte das comunidades locais.

\section{Por que é importante recuperar esa memoria e, con ela, o patrimonio?}

Reflexión sobre as consecuencias da perda dese patrimonio. Seguindo a matriz empregada por Criado-Boado que representa a ontoloxía do patrimonio arqueolóxico (en diante, PA) (Criado-Boado, 2012: 193-194), este represéntase con tres dimensións: como documento (do pasado), como obxecto (do pasado no presente) e como recurso (no presente). Neste último caso, no que o PA está composto por obxectos e documentos, temos a obriga de estudalo e xestionalo no presente. Isto é extensible a calquera elemento que forme parte dese PA, especialmente no caso da arquitectura, onde a súa conservación e mantemento está ligada ao seu uso. $\mathrm{O}$ uso que lle deamos a esta arquitectura dependerá de moitos factores; en primeiro lugar, das políticas patrimoniais, pero tamén do seu réxime de propiedade, do seu estado de conservación e, ante todo, do seu recoñecemento social. O PA que non se coñece e non se valora socialmente dificilmente pode ser estudado, conservado e usado. 


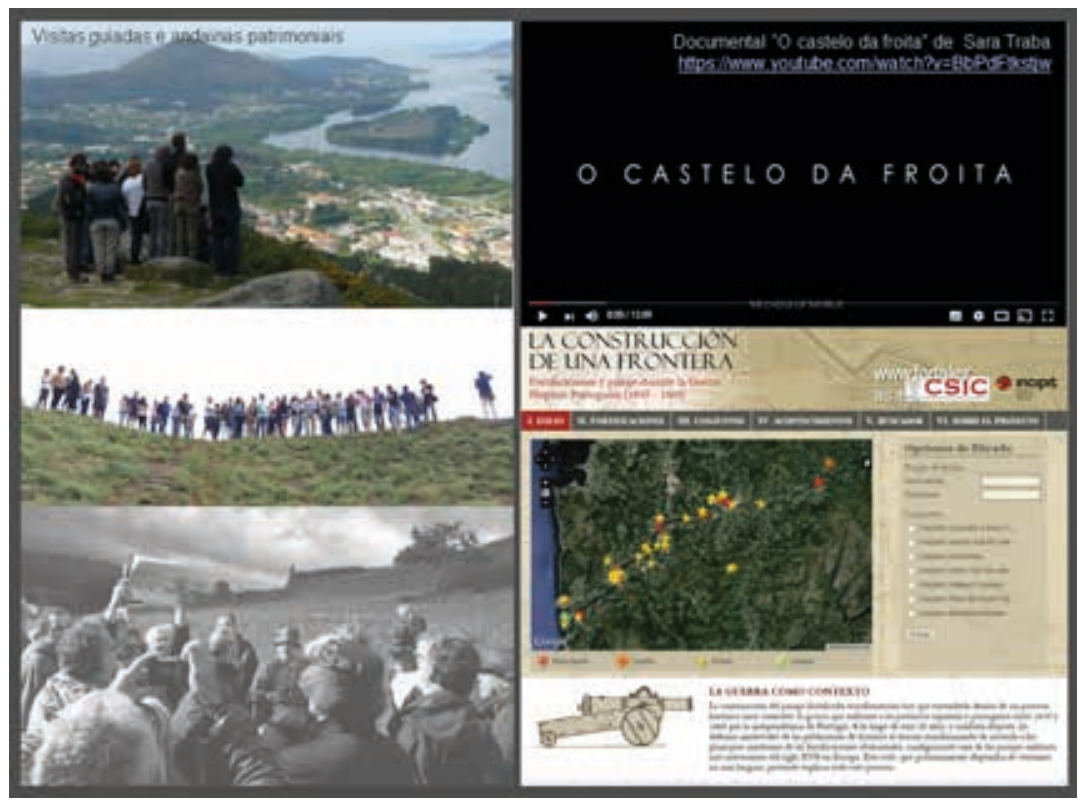

Figura 11. Estratexia 1: pór en valor o patrimonio. No proceso de recuperación da memoria desta paisaxe o relato foise dotando de contido e comezou un proceso de reencontro con estes espazos, de posta en valor que abrangueu distintas accións

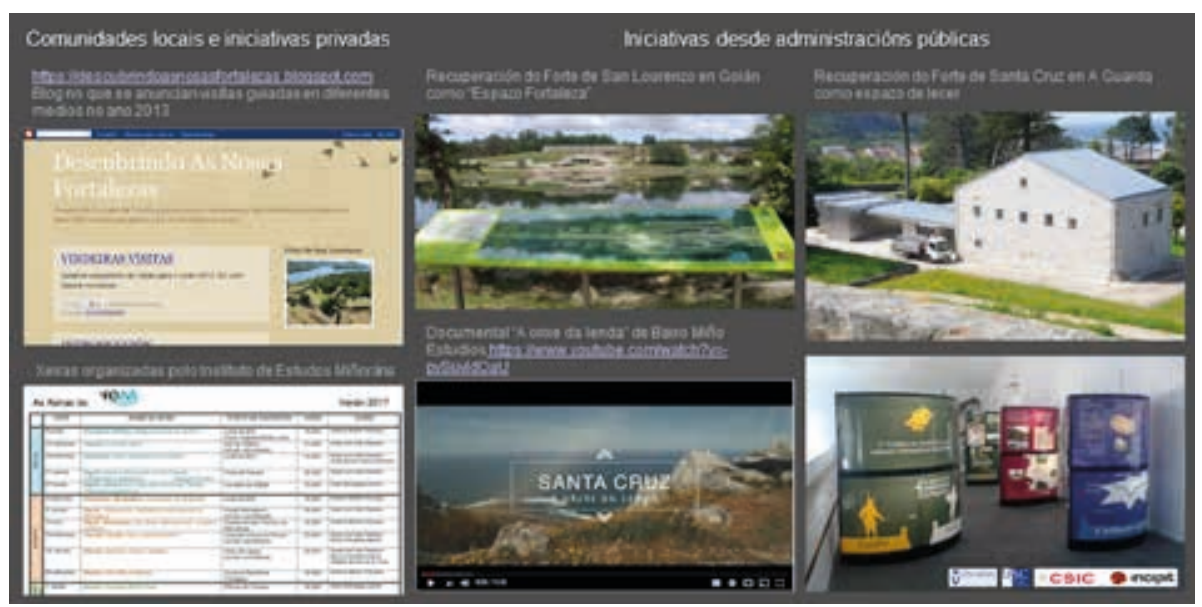

Figura 12. Estratexia 2: converter o patrimonio nun recurso cultural. Xa con posterioridade, leváronse a cabo diferentes iniciativas por parte tanto de particulares coma de asociacións locais ou de administracións públicas, encamiñadas a dotar esta paisaxe e os seus elementos nun recurso cultural. Este aspecto aínda está por acabar de ser definido e de «explotar», patrimonialmente falando, en toda a Raia Húmida. Porén, para chegar até aquí, era necesario desenvolver todos as fases da CVPC 


\section{MATERIALIDADES E PATRIMONIOS}

Durante o proceso de análise de toda esta paisaxe identificouse unha serie de materialidades de natureza homoxénea, mais todas elas parecían ter unha relación entre si que podiamos identificar a través das propias crónicas e fontes históricas que narraban os feitos da guerra (i. e., Ávila y La Cueva, 1895; Ericeira, 1945, ou Gándara, 1677) e como, no seu devir, se ían modernizando as defensas medievais das vilas e cidades da Raia ou se construían novas fortificacións nas súas contornas para protexer a poboación dos ataques do exército inimigo con novas armas de fogo para as que as torres e os castelos medievais non estaban preparados mentres non se remataban as novas defensas. Identificar estas materialidades, caracterizalas e valorizalas foi o proceso que levou a converter cada un destes elementos e o conxunto que conforman, a paisaxe fortificada miñota, en patrimonio.

Actualmente, dous son os conxuntos defensivos nos que se levou a cabo unha maior actividade encamiñada á súa posta en valor, coa importante (pero irregular e insuficiente) intervención por parte das administracións públicas na recuperación dos seus espazos, tal e como recollemos na figura 12. Para ilustrar apenas unha parte desta materialidade, retomamos a figura 6 , onde se mostra un dos conxuntos defensivos analizados na Raia, o de Goián-Vila Nova de Cerveira-Medos.

As fortificacións que compoñen este sistema son, en Portugal, a Praça Forte de Vila Nova de Cerveira, os fortes de Lovelhe e de São Francisco, e a batería da Mata ou Atalaia do Espírito Santo. En Galicia, estarían, en Goián, o forte da Barca, a fortaleza de Nosa Sra. da Concepción, o forte das Chagas, a torre dos Ratos e a torre dos Correa e, en Estás, o castelo de Medos e forte de Santiago Carrillo.

Existían tanto no lugar da Barca coma en Vila Nova unha poboación en época medieval. No caso da Barca, estaba defendida por unha pequena torre. Tras as primeiras incursións na vila en 1643 por parte dos portugueses, levántanse unhas trincheiras no lugar da Barca, no porto, e constrúese un pequeno forte de catro baluartes «que rodeabam uma torre antiga» (Ericeira, 1945, vol. IV: 170) en 1644 denominado forte da Barca. 

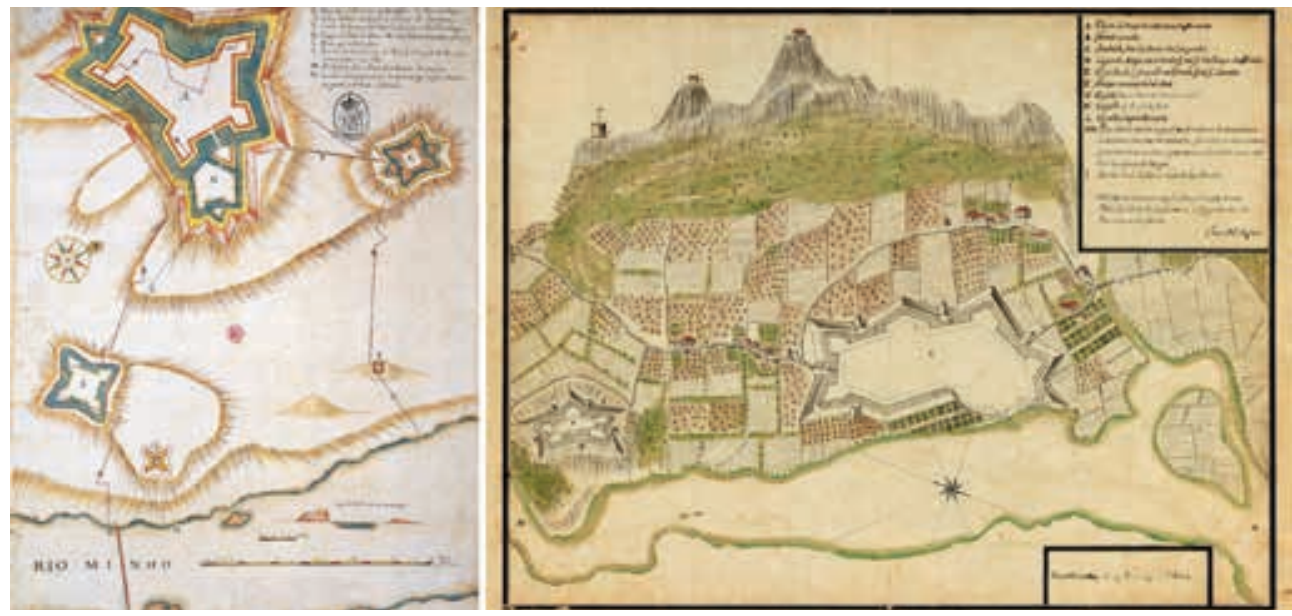

Figura 13. Á esquerda, plano histórico da fortaleza de Nosa Sra. da Concepción, en Goián, e as fortificacións que a rodean, ademais das trincheiras que as unen. Está atribuído por Garrido a Miguel de Lescol (aprox. 1664) (Garrido, 2004: 17) ${ }^{12}$. Á dereita, planta de Vila Nova de Cerveira e fortificacións próximas de Joze Miz.s da Cruz (1759) (GEAM 2145, Lisboa, copia no Arquivo privado de Jaime Garrido)

No lugar de Vila Nova (anteriormente, Cerveira) existía un castelo polo menos desde o século XIII que aínda se conserva, mais que foi obxecto dalgunhas reformas posteriores. Ten unha planta ovalada rodeada dunha muralla con varias torres cuadrangulares no seu perímetro (figura 14). Contaba con dúas portas, unha ao leste, denominada Porta da Vila, e outra ao oeste, cara ao río, denominada Porta da Traição. En 1320, pasa a denominarse Vila Nova de Cerveira cando D. Dinis lle outorga a Carta Foral. A barbacá constrúese nos séculos XIV e XV. Existen ademais referencias a outras reformas nas defensas tanto no século XV coma no XVI. En 1641, o gobernador de armas de Entre Douro e Minho mandou atrincheirar a vila.

${ }^{12}$ Existen informacións contraditorias sobre este plano conservado na Biblioteca Nacional de Lisboa (http:// purl.pt/25504). O plano non está datado nin firmado, pero na ficha correspondente da Biblioteca Nacional de Portugal atribúese a Manuel Pinto de Vilalobos e dátase en 1713. Se analizamos en detalle o plano e o comparamos con outros do mesmo autor realizados entón, veremos que difiren a grafía, a forma de representar as fortificacións, os trazos da topografía ou as cores. Por outra parte, con respecto ao forte de San Lourenzo, no plano especifícase o seguinte: «Forte que se ha de facer». Este forte iníciase en 1672 e remátase 1673, como sabemos, polo que en 1713 xa debería estar construído. Pola contra, Jaime Garrido considera que foi elaborado por Miguel de Lescol arredor de 1664, quen estaba traballando nesa data nas fortificacións portuguesas da fronteira do Minho ás ordes do conde de Prado (Garrido, 2004: 17). Nós, tendo en conta as diferenzas cos planos de Vilalobos e a data de construción do forte de San Lourenzo, decantámonos pola hipótese de Garrido. 


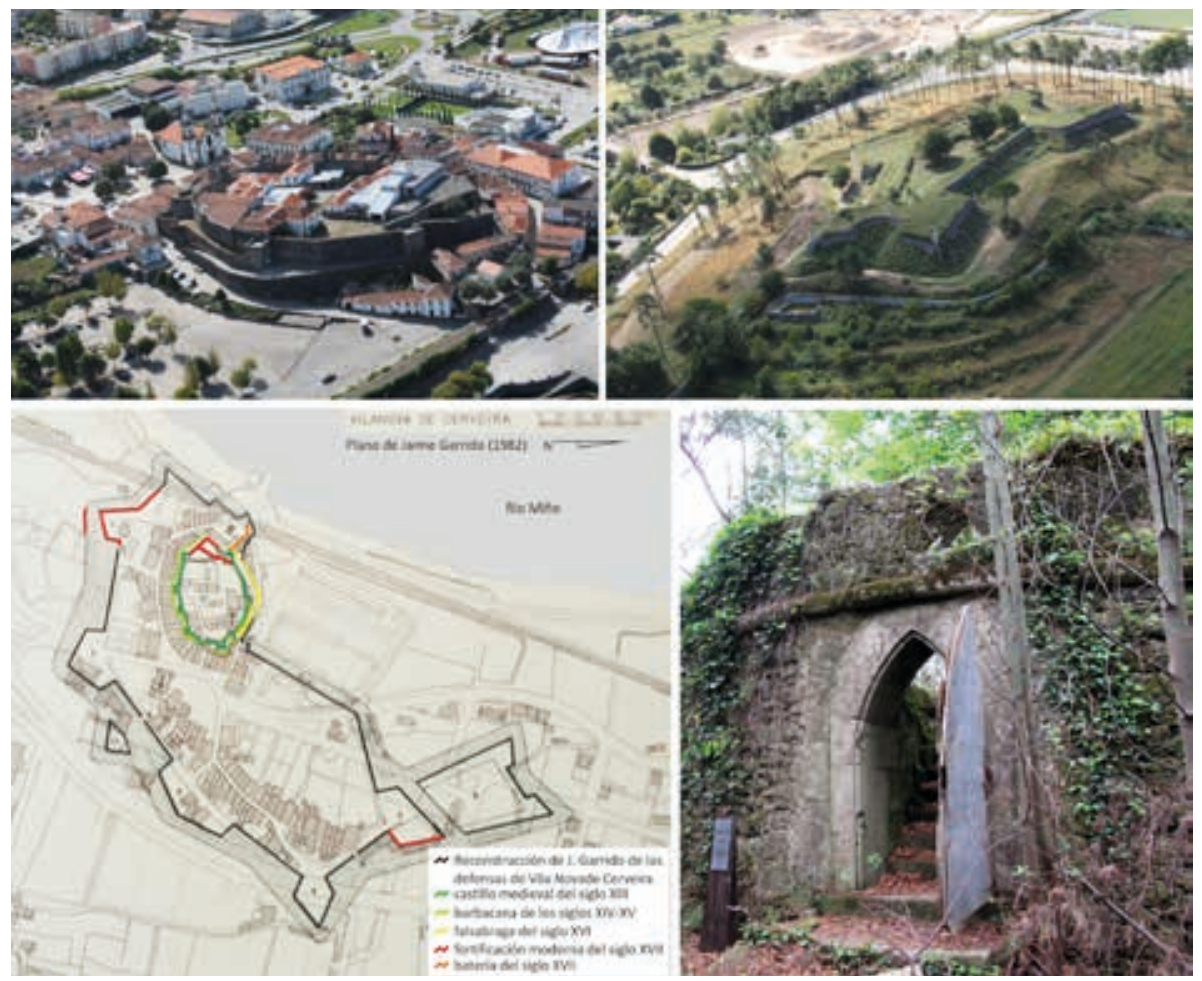

Figura 14. Arriba, vistas aéreas do castelo de Vila Nova de Cerveira (esquerda) e do forte de Lovelhe de 2009 (dereita) (proporcionadas por Terra Arqueos S. L.). Abaixo, á dereita, fotografía da porta de acceso á Atalaia do Espírito Santo do 2009; á esquerda, plano coa delimitación das estruturas fortificadas conservadas en Vila Nova de Cerveira

A actividade construtora comeza de maneira máis intensa no lado portugués, xa que será necesaria como apoio loxístico á toma da súa veciña A Barca. En 1642, comézase o forte de São Francisco, situado na poboación de Lovelhe, a $1 \mathrm{~km}$ ao norte de Vila Nova nunha eminencia desde a que se domina esta vila e o lugar da Barca. Non se concluirá até 1663 , pero en «1643 asiste ao asedio das tropas galegas a Vila Nova, mais aínda estaba ao inicio dos traballos» (CADIVAFOR, 2008: 141). Trátase dun forte de planta pentagonal con cinco baluartes, tres cortinas, foso, camiño cuberto e unha única porta polo sueste. É unha obra permanente coas defensas exteriores de terra. Actualmente, é un dos fortes que mellor se conservan na zona (figura 14). 
Descoñecemos o momento de construción da Atalaia do Espírito Santo (figura 14), pero as súas características tipolóxicas e construtivas responden ao tipo de fortificación que nos ocupa. Esta batería localízase no último chanzo cara ao río Miño da serra da Gávea, que, xunto coas de Salgosa e Coba, forman un arco que rodea a rexión de Vila Nova de Cerveira achegándose case até o río Miño. Nun alto, dominando Lovelhe, Vila Nova e Goián, disponse un pequeno reduto de planta rectangular, coas esquinas moi saíntes pero sen chegaren a formar baluartes, realizado en cachotaría irregular. Está rodeado dun foso cortado na rocha e sobre o reduto consérvase unha torre de planta circular con catro troneiras na parte superior. As representacións que se conservan dela son de planos xerais (Blanco-Rotea, 2015: 475-478). Desde este posto controlaba, ademais das poboacións xa comentadas, o paso cara ao seguinte subsistema de Valença-Tui.

Existiu tamén un proxecto para a construción dun pequeno fortín nun illote situado ao suroeste de Vila Nova, enfrontado ao forte de San Lourenzo (e antes ao forte da Barca), pero non conservamos evidencias da súa construción (Blanco-Rotea, 2015: 469-471).

A fortaleza moderna de Vila Nova de Cerveira levantouse entre 1660 e 1667 segundo o proxecto de Francisco de Acevedo. A súa construción abordouse en paralelo coa da Nosa Sra. da Concepción, en Goián. A praza envolveu o castelo medieval e o casarío que se fora construíndo extra muros polo sur, o leste e o norte. Contaba con catro baluartes, dous semi-baluartes e tres redutos virados ao río, e estaba rodeado dun foso. Ademais, na zona norte tiña un hornaveque e un revelín protexendo unha das cortinas ao leste (pódese ver a planta na figura 13). Actualmente consérvanse apenas restos deste trazado moderno, como se pode ver na figura 14.

Xa no lado galego, a excepción do forte da Barca, toda a defensa se constrúe a partir da toma do lugar polos portugueses en 1663 e é de autoría lusa (figura 15). En primeiro lugar, levántase, nunha eminencia ao NNO do forte da Barca a Fortaleza de Nosa Sra. da Concepción, un forte terreiro de grandes dimensións, de planta irregular con cinco baluartes e un hornaveque con dous semi-baluartes cara ao leste. Na gola do hornaveque localizábase un revelín que protexía o acceso ao recinto (Blanco-Rotea, 2015: 332-338). Iniciouse en 1663 e pronto se rematou. Aínda que os planos que se conservan da fortificación non están firmados (figura 13), algúns autores consideran que a súa autoría é do enxeñeiro Manuel 
Pintos de Villalobos (http://www.cieform.org/detalle.cis?id=10, consulta de xuño de 2010) mentres que outros lla atribúen a Miguel de Lescol (Garrido, 2004: 17). A fortaleza atópase moi arrasada, tanto pola afección do crecemento urbano, coma pola concentración parcelaria, a construción dunha posta e unha areeira, a repoboación etc., xa no remate da guerra foi destruída parcialmente cando se devolveron as prazas ao país contrario.

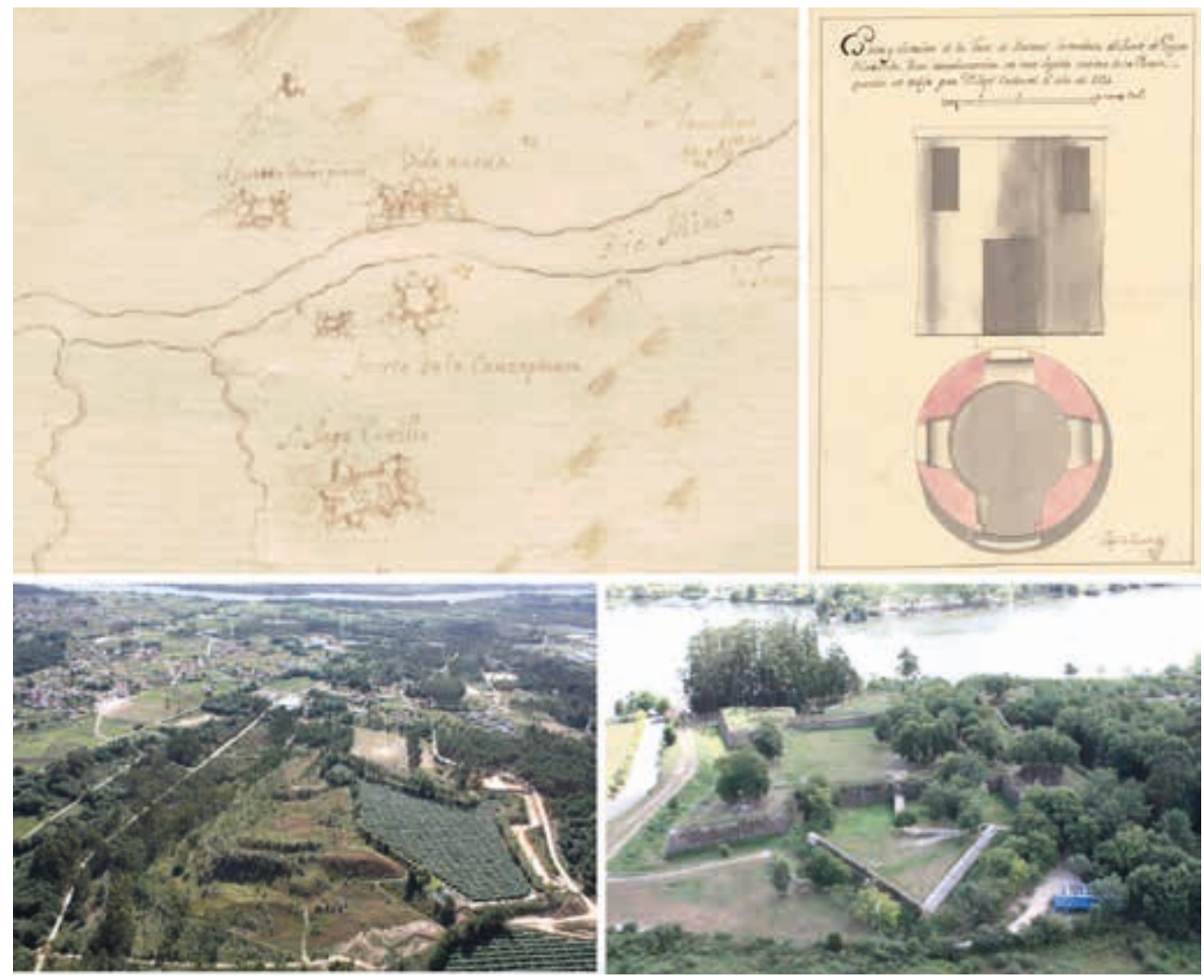

Figura 15. Arriba á esquerda, recorte do Mapa y diseño de la Frontera de Galicia (Arquivo do Museo Naval de Madrid —Signatura: MN-E-19-22; http://bibliotecavirtualdefensa.es/BVMDefensa/i18n/consulta/ resultados ocr. cmd? buscar cabecera=Buscar\&id=717\&tipoResultados=BIB\&posicion=69\&forma=ficha, consulta de 13/11/2018); á dereita, Plano, y elevación de la Torre de ratones inmediata del Fuerte de Goyan, de Josef La Fuente, recollido na Relación topográfica de las plazas, y puestos Fortificados del Reyno de Galicia de Miguel de Hermosilla, de 1800 (Biblioteca Central Militar — Localización: GF — Signatura: GF-MS-1/1; http://bibliotecavirtualdefensa.es/BVMDefensa/i18n/consulta/registro.cmd?id=16674, consulta de 05/04/2018). Abaixo á esquerda: forte de Medos, en Estás, e á dereita, forte de San Lourenzo, en Goián (proporcionadas por Terra Arqueos S. L.) 
Esta fortificación completábase co forte das Chagas, do cal se pensaba que non se conservaba nada; porén, grazas á análise dos datos LiDAR, púidose documentar a súa planta, baixo o arboredo de repoboación, practicamente enteira. Está situado a medio quilómetro cara ao norte, completando o dominio visual por este flanco cara ao río da fortaleza principal da Concepción. A planta corresponde a un cadrado con catro baluartes e dous revelíns ou medias lúas (figura 16).

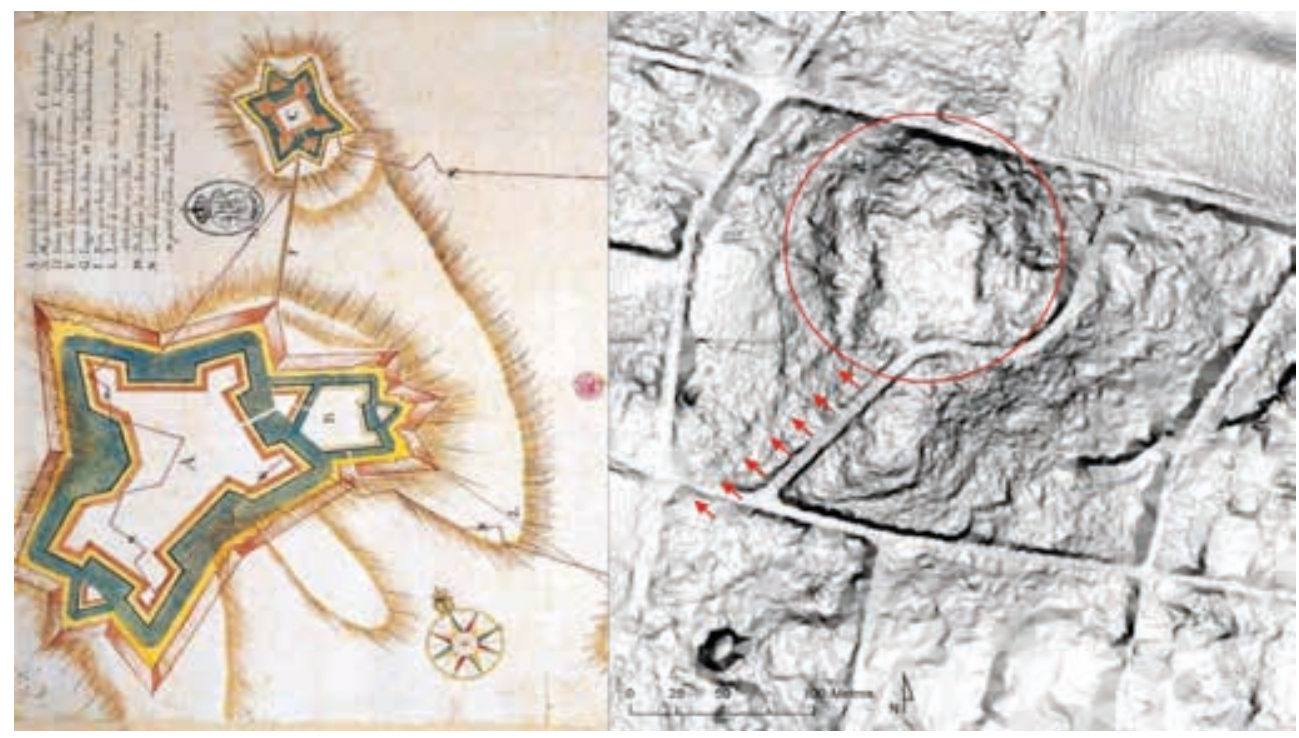

Figura 16. Á esquerda, recorte do plano histórico da Fortaleza de Nosa Sra. da Concepción, en Goián, atribuído por Garrido a Miguel de Lescol (aprox. 1664); á dereita, mapa de pendentes obtido a partir dos datos LiDAR da área na que se sitúa o forte das Chagas. Marcouse a liña de comunicación coa fortaleza de Nosa Sra. da Concepción cunhas frechas

Nunha eminencia situada en fronte do forte de Lovelhe denominada A Atalaia, sobre un xacemento romano, constrúese unha torre coñecida como torre dos Ratos, da cal conservamos unicamente a rocha cortada para a súa disposición na localización e o foso que rodeaba a eminencia. Non coñecemos a data de construción nin a súa autoría, pero varios autores apuntan a que se trataba dunha torre de vixilancia en relación co forte de San Lourenzo e o control do paso sobre o río Miño á altura de Lovelhe. Polo debuxo que se conserva de Joséf La Fuente na obra de Miguel de Hermosilla (figura 15), trataríase dunha torre de planta circular con tres ventás e unha porta, e estaría realizada en pedra con cantaría nos vans. 
Ademais de todas estas construcións, habería que engadir a torre dos Correa, que tampouco se conserva e sería de época anterior, e un sistema de trincheiras que comunicaba as fortificacións entre si, como se pode apreciar na figura 13. Aínda hoxe se observan parte destas trincheiras, que se dirixían directamente desde A Concepción e a torre dos Ratos até o río, de maneira que se podía acceder por elas desde os pasos de barcas cara á terra.

Fronte a este complexo sistema portugués con enclave en ambos os dous reinos (comunicados polos pasos de barcas), o exército español decide fortificarse a $3 \mathrm{~km}$ ao norte no lugar de Estás, cortando o paso cara a Tui. Constrúese alí o forte de Medos ou de Santiago Carrillo. Trátase dunha fortificación de campaña de grandes dimensións, formada por dous recintos (figura 15, imaxe inferior esquerda). O recinto norte é un reduto de planta irregular, con dous baluartes ao sur e cunha entrada defendida por unha media lúa. $O$ reduto sur é unha coroa con dous baluartes e un semi-baluarte polo lado sur. Estaba ademais rodeado por fosos e camiños cubertos. $\mathrm{Na}$ figura 15, pódese apreciar como desde o forte se dominan Vila Nova e Goián, que se localizarían no extremo superior dereito da fotografía, á altura da ponte internacional que cruza o río Miño.

Unha vez devoltas as prazas ao remate da guerra coa firma do Tratado de Lisboa en 1668, decídese desmantelar algunhas das construcións en terra, como sucedería aquí coas Chagas, A Barca ou Nosa Sra. da Concepción, e construír un novo forte de construción permanente máis próximo ao río que permita manter o control do paso fronteirizo. Levántase así o forte de San Lourenzo (figura 15, imaxe inferior dereita):

Que el fuerte de Goyan letra D donde antes estaba la Atalaya se haga todo de nuevo por ser puesto mas inmediato vatir con artillería y mosquetería a Villanueva, y que en el interin que se hace, se mantenga el fuerte letra B que llaman de las llagas y se desmantelará después que esté acabado el de Goyán, y para la fabrica de este puesto se podrá valer de los materiales del fuerte de la Concepción que se desara luego. 13 de agosto de 1688. Yo la Reina. (Soraluce, 1985: 179)

Os planos foron revisados polos enxeñeiros Carlos e Fernando Grunnenberg; a construción comezou en 1691 e finalizou en 1693. Trátase dun forte de planta 
cadrada con catro baluartes, tres revelíns protexendo as cortinas noroeste, suroeste e sueste, e foso que rodea o reduto e os revelíns.

$\mathrm{Na}$ figura 6, pode observarse como queda configurado o mapa do subsistema de Goián-Vila Nova de Cerveira-Medos. Coa ocupación desta zona, os portugueses dominan un dos accesos cara ao interior de Galicia e cara aos subsistemas veciños, ao SSO o da Guarda-Caminha e cara ao nordeste o de Tui-Valença. Cara a Tui, aínda que se levaron a cabo algunhas incursións por parte do exército portugués, os avances eran freados entre o forte de Medos e o de Amorín. No entanto, conseguiron penetrar polo val do Rosal para acabar ocupando A Guarda. Ademais, a serra de Argalo en Galicia e as da Gávea, Salgosa e Coba envolven este pequeno espazo, como se dunha comarca natural se tratase, que acaba permitindo a creación deste subsistema no que os portugueses dominan o lado sur da vía de tránsito e os galegos, o norte (véxase tamén a figura 17).

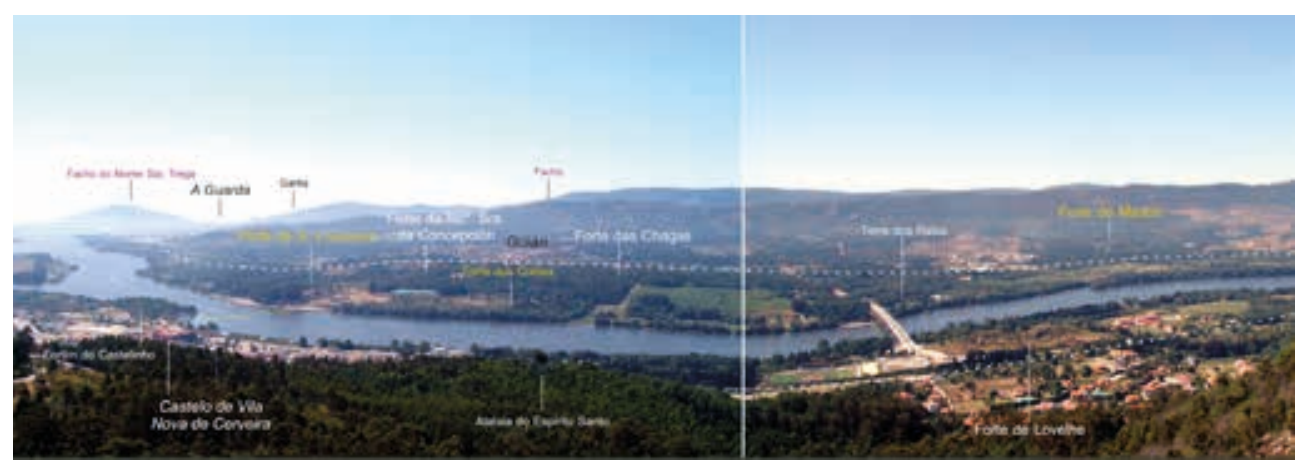

Figura 17. Desde o conxunto ou subsistema de Goián-Vila Nova de Cerveira-Medos, exércese un control directo dos pasos de barca sobre o Miño e das vías que descorren en paralelo ao río por ambos os territorios. O exército portugués entra por Goián, aséntanse e fai diversas incursións en Galicia, coma no caso da Guarda

\section{REVERSIÓN/RECEPCIÓN/INCLUSIÓN}

A raíz do traballo que teño a sorte de desenvolver desde hai anos na fronteira miñota, xorden varias reflexións na liña do impacto do que facemos como investigadoras e investigadores, que non sempre ten en conta as propias comunidades locais e os seus intereses. Como pouco, lévanos a pensar na dificultade entre a necesidade de conciliar a xestión patrimonial, con todo o que este concepto 
implica (e máis se o facemos desde a CVPC), como xa vimos, e os intereses das comunidades que conviven con ese (e viven ás veces dese) patrimonio. Por unha banda, temos a obriga desde a nosa profesión, mais tamén como sociedade, de coñecer e conservar o noso legado, e mantelo para as xeracións futuras, pero tamén de acrecentalo. Por outra, temos a obriga de contar coas comunidades locais, herdeiras directas, cando facemos isto.

Levo anos visitando e vivindo o Baixo Miño. Unha parte das miñas orixes vén do Rosal. En varias ocasións, asistín á conmemoración da toma de Goián por parte de Vila Nova de Cerveira. Eu percibina así como vou describir. Hai que dicir que esta vivencia é anterior á última gran reforma do forte de San Lourenzo (a creación do Espazo Fortaleza), cando este, escondido tras unha cortiña de árbores, lle daba as costas ao río. A finais de agosto, reproducindo o momento da toma de 1663, pola noite os nosos veciños e veciñas portugueses lanzan fogos artificiais desde Vila Nova e desde unha barca situada diante do Castelinho. Escóitase música ao lonxe, o estoupar dos fogos, as voces e os aplausos ao outro lado do río. Na beira galega, o silencio, apenas uns murmurios da xente. Situabámonos en fila empolicados ao muro que delimitaba a observar os fogos. Ao rematar a tirada, tamén en fila e nun silencio apenas roto de cando en vez por algún murmurio, iámonos ás nosas casas. Sempre me chamou a atención observar aquela escena; observar o contraste entre ambas as percepcións, a pesar da distancia de máis de tres séculos entre o feito histórico e a súa recuperación por parte das comunidades locais. En Galicia, ademais, a escena ocorría de costas á materialidade do conflito, o forte de San Lourenzo estaba oculto tras a pantalla de árbores e maleza e nin sequera asistía como espectador ao que alí pasaba; os seus veciños, Concepción, As Chagas, A Barca... estaban destruídos ou esquecidos nun curruncho da memoria. A re-significación desta paisaxe e os seus compoñentes, a recuperación do forte de San Lourenzo e a súa contorna, a súa apertura ao río e a construción dunha bancada no seu glacis iniciaron un novo proceso de patrimonialización, recuperaron a memoria esquecida e revertérona socialmente. Hoxe, haberá que comprobar se as percepcións dos asistentes mudaron tras o proceso de re-significación deste patrimonio e a xeración dun novo espazo para o diálogo, ou se, a pesar do esforzo, continúan sendo as mesmas.

Nos dous últimos anos, tiven a oportunidade de asistir a varias actividades centradas neste patrimonio que xa non xurdían desde os axentes implicados neste 
proceso de investigación, senón que proviñan desde comunidades locais coma o Instituto de Estudos Miñoráns ou a Asociación Sociocultural Senraia, ou os colexios CEIP de Sobrada (Tomiño) e CEIP Pintor Antonio Fernández de Goián. Son iniciativas moi distintas, pero cun obxectivo común: coñecer, valorizar e dar relevancia social ao patrimonio. Nestes casos, creo que estabamos no bo camiño.

Aínda así, cada vez que dotamos dun relato estes elementos e que recuperamos a súa memoria e iniciamos eses procesos de reversión social (que non sempre de inclusión social), os resultados poden ser moi variables. Igual ca en Goián, na vila da Guarda houbo un proceso, en certo modo parello ao de San Lourenzo, no forte de Santa Cruz. A historiadora da arte e directora de cine Sara Traba realizou no ano 2016 a curtametraxe $O$ castelo da froita (https://www.youtube.com/ watch?v=BbPdFtkstjw), baseada na fortaleza de Santa Cruz na Guarda e que foi presentada ao I Festival de Curtametraxes sobre o Patrimonio Arqueolóxico da Provincia de Pontevedra Telearqueoloxía 2016. Esta curtametraxe non se centraba tanto no forte coma na percepción que cinco personaxes reais (veciños e veciñas da Guarda) teñen del e, sobre todo, da súa recuperación unha vez que volveu a mans públicas e foi sometido a un proceso de restauración e rehabilitación. Cada un deles ten unha vinculación co castelo, normalmente indirecta (o avó, a nai, a avoa, a costureira...). Porén, todos eles o recordan por un elemento en común: a froita. E non todos teñen a mesma percepción, interese e sensación ante este proceso. Creo que o mellor peche ao que quería transmitir neste texto é recomendarvos que o vexades e, logo, reflexionedes sobre el, os personaxes e o que facemos na xestión patrimonial. A curta pecha moitas lecturas. Sobre todo, que non hai unha única lectura. Ao final, o patrimonio é multivocal e nós somos diversas e diversos. 


\section{REFERENCIAS BIBLIOGRÁFICAS}

Almeida, Carlos A. F. de (1968): Vias Medievais. I. Entre-Douro-e-Minho, Porto, ed. autor.

AlmeIDA, Ernesto Iglesias (1984): Los antiguos «portos» de Tuy y las barcas de pasaje a Portugal, Tui, ed. autor. ALMEIDA, Ernesto Iglesias (2013): «La Guerra de Independencia de Portugal en la frontera galaico portuguesa», Diversarum Rerum. Revista de los Archivos Catedralicio y Diocesano de Ourense, 8, 393-402.

Amado Reino, Xesús / David Barreiro / Felipe Criado-Boado / María del Carmen Martínez López (2002): «Especificaciones para una gestión integral del impacto desde la Arqueología del Paisaje», TAPA (Traballos de Arqueoloxía e Patrimonio), 26, Santiago de Compostela, Laboratorio de Patrimonio, Paleoambiente e Paisaxe.

ANDRADE, Amélia A. (1994): Vilas, poder régio e fronteira: o exemplo de Entre Lima e Minho medieval, tese de doutoramento en Historia da Idade Media, policopiada, Lisboa, Faculdade de Ciências Sociais e Humanas, Universidade Nova de Lisboa.

Andrade, Amélia A. (1998): «A estratégia dionisina na fronteira noroeste», Revista da Facultade de Letras. História, 15:1, 163-176.

Anschuetz, Kurt F. / Richard H. Wilshusen / Cherie L. Scheick (2001): «An Archaeology of Landscapes: Perspectives and Directions", Journal of Archaeological Research, 9:2, 157-211.

Ávila y La Cueva, Francisco A. (1852; ed. fac. 1995): Historia Civil y Eclesiástica de la Ciudad de Tuy y su Obispado. vols. 1-2, Santiago de Compostela, Consello da Cultura Galega.

Barreiro Martínez, David (2009): «Arqueología aplicada: la revalorización del patrimonio arqueológico», en III Seminario Internacional Municipio de Envigado. Gestión del Patrimonio Arqueológico, Envigado (Colombia), 4 de agosto de 2009 (comunicación, inédita).

Blanco-Rotea, Rebeca (2008): «El Castillo de la Palma (Mugardos, A Coruña). Un enclave defensivo en la Ría de Ferrol», TAPA (Traballos de Arqueoloxía e Patrimonio), 40, Santiago de Compostela, Instituto de Estudos Galegos Padre Sarmiento, CSIC.

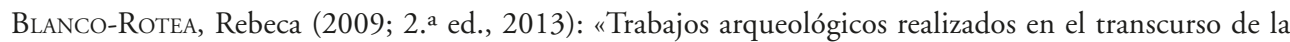
redacción del Plan Director de las Fortalezas Transfronterizas del Tramo Bajo del Río Miño", CAPA (Cadernos de Arqueoloxía e Patrimonio), 22, Santiago de Compostela, Grupo de Investigación en Arqueología del Paisaje, Universidade de Santiago de Compostela.

Blanco-Rotea, Rebeca (2011a): «Herramientas metodológicas aplicadas al estudio de un paisaje urbano fortificado: el caso de la villa de Verín (Monterrei, Ourense)», en María Domingo Fominaya / Antonio J. Sánchez Luengo (dirs. e coords.), Arqueología aplicada al estudio e interpretación de edificios históricos. Últimas tendencias metodológicas, Madrid, Ministerio de Cultura, 179-197.

Blanco-Rotea, Rebeca (2011b): «Las fortificaciones de Goián-Vila Nova de Cerveira-Medos en el territorio fortificado transfronterizo galaico-portugués», Revista Castillos de España, 58 (164-165-166), 139-145.

Blanco-Rotea, Rebeca (2015): Arquitectura y paisaje. Fortificaciones de frontera en el sur de Galicia y norte de Portugal, tese de doutoramento, Vitoria-Gasteiz, Universidad del País Vasco.

Blanco-Rotea, Rebeca (2017): «Arquitectura y paisaje. Aproximaciones desde la arqueología», Arqueología de la Arquitectura, 14: e051 (doi: http://dx.doi.org/10.3989/arq.arqt.2017.007).

BLANCO-RotEA, Rebeca (2018): «Paisajes urbanos modernos de la frontera galaico-portuguesa. La fortificación de las villas y ciudades en el siglo XVII», Monográfico «Cidade (in)defesa», Revista de História da Arte, 13, $10-35$. 
BouzA, Fernando Jesús (1991): «Primero de diciembre de 1640: ¿̨una revolución desprevenida?», Manuscrits. Revista d Història Moderna, 9, 205-225.

BouZA, Fernando Jesús (1993): «1640 perante o Estatuto de Tomar. Memória e Juízo do Portugal dos Filipes», Penélope. Fazer e desfazer história, 9/10, 17-27.

Caballero Zoreda, Luis (1995): «Método para el análisis estratigráfico de construcciones históricas o "lectura de paramentos" ", Informes de la Construcción, 46:435, 37-46.

CADIVAFOR (2008): Catalogación, Digitalización y Valoración de las Fortalezas Defensivas de la Frontera de Galicia Norte de Portugal, Ferrol, CIEFAL, CIS Galicia, E. S. Gallaecia.

Cobos-Guerra, Fernando (2005): «Los sistemas de fortificación como patrimonio heredado», en Alicia Cámara (coord.), Los ingenieros militares de la monarquía hispánica en los siglos XVII y XVIII, Madrid, Ministerio de Defensa / Asociación Española de Amigos de los Castillos / Centro de Estudios Europa Hispánica, 271-291.

Cobos-Guerra, Fernando (2011): «El sistema de fortificaciones abaluartadas de la raya hispano portuguesa como patrimonio de la humanidad. Caracterización y valoración del sistema. Estado de la cuestión», Castillos de España, 58 (164-165-166), 155-166.

Cobos-Guerra, Fernando / Antonio Hoyuela Jayo (2005): «Metodología de estudio e intervención del Plan Director de las fortalezas fronterizas del Bajo Miño», en Alfredo González Ruibal (coord.), Actas del III Congreso de Castellología Ibérica (28 de octubre-1 de noviembre, Guadalajara), Madrid, Asociación Española de Amigos de los Castillos / Diputación de Guadalajara, 695-715.

CostA, Fernando Dores (2005): «Interpreting the Portuguese War of Restoration (1641-1668) in a European Context», e-JPH, 3:1, 1-14.

Criado-Boado, Felipe (1996a): «El futuro de la arqueología, ¿la arqueología del futuro?», Trabajos de Prehistoria, 53:1, 13-26.

Criado-Boado, Felipe (1996b): «Hacia un modelo integrado de gestión de investigación y gestión del Patrimonio Histórico: la cadena interpretativa como propuesta», Boletín del Instituto Andaluz del Patrimonio Histórico, 16, 73-78.

CRIADO-BOADO, Felipe (1999): «Del terreno al espacio: planteamientos y perspectivas para la arqueología del paisaje», CAPA (Cadernos de Arqueoloxía e Patrimonio), 6, Santiago de Compostela, Grupo de Investigación en Arqueología del Paisaje, Universidade de Santiago de Compostela.

Criado-Boado, Felipe (2012): Arqueológicas. La razón perdida, Barcelona, Edicións Bellaterra S. L.

Ericeira, Conde da (1945): História de Portugal Restaurado, Porto, Livraria Civilização.

Fernández de Medrano, Sebastián (1700; ed. fac. 2001): El arquitecto perfecto en el arte militar, Bruxelas, Casa de Lamberto Marchant (ed. fac., Valladolid, Editorial MAXTOR).

Ferreira Priegue, Elisa (1988): «Los caminos medievales de Galicia», Boletín Auriense, Anexo 9.

GÁNDARA, Felipe de la (1677): Nobiliario, armas, y triunfos de Galicia, hechos heroicos de sus hijos, y elogios de su nobleza, y de la mayor de España y Europa, Madrid, Julián de Paredes.

Garrido Rodríguez, Jesús (2004): Fortificaciones del río Miño, memoria histórica inédita realizada durante os traballos de redacción do Plan Director Fortrans, Vigo.

González Méndez, Matilde (1999): Investigación y puesta en valor del Patrimonio Histórico. Planteamientos y Propuestas desde la Arqueología del Paisaje, tese de doutoramento da área de Humanidades e Ciencias Sociais, inédita/cd-rom, Santiago de Compostela, Universidade de Santiago de Compostela.

Heilen, Michael P. (2005): An Archeological Theory of Landscapes, Arizona, The University of Arizona. 
Jones, David M. (2010): The Light Fantastic. Using airborne lidar in archaeological survey, Swindon, English Heritage, Customer Services Department.

Knapp, A. Bernard / Wendy Ashmore (1999): «Archaeological Landscapes: Constructed, Conceptualized, Ideational», en Wendy Ashmore / A. Bernard Knapp (eds.), Archaeologies of Landscape. Contemporary Perspectives, Malden (Massachusetts), Blackwell, 1-30.

Llobera, Marcos / Pastor Fábrega-Álvarez / César Parcero-Oubiña (2011): «Order in Movement: a GIS approach to accessibility", Journal of Archaeological Sciences, 38, 843-851.

Lock, Gary R. I Zoran STANCIC (1995): Archaeology And Geographic Information Systems: A European Perspective, London, Taylor \& Francis.

LuCuZE, Pedro de (1772): Principios de fortificación, que contienen las definiciones de los terminos principales de las obras de Plaza, y de Campaña, con una idea de la conducta regularmente observada en el Ataque, y Defensa de las Fortalezas, Barcelona, Thomas Piferrer.

Matos, João Barros (2016): «As fortalezas abaluartadas de Mazagão, Ceuta e Diu. Implantação e relação com o território", en Francisco J. Rogado Contente Domingues (ed.), Actas do XXIV Colóquio de Histórica Militar "Nos 600 Anos da Conquista de Ceuta - Portugal e a Criação do Primeiro Sistema Mundial», Lisboa, Comissão Portuguesa de História Militar, 27-39.

Pallares, María del Carmen (1987): «Sistema feudal y proceso de urbanización: algunas reflexiones a propósito del caso gallego en los siglos XII y XIII", en Jubilatio-Homenaje de la Facultad de Geografía e Historia a los Profesores D. Manuel Lucas Álvarez y D. Ángel Rodríguez González, Santiago de Compostela, Universidade de Santiago de Compostela, t. I, 95-105.

PAllares, María del Carmen / Ermelindo Portela (2015): «Para una lectura histórica del paisaje. La impronta medieval», en Gerardo Pereira Menaut / Ermelindo Portela Silva (eds.), El territorio en la historia de Galicia. Organización y control. Siglos I-XXI, Santiago de Compostela, USC / Editora Académica, 97-151.

PARKER, Geoffrey (2002): La revolución militar. Innovación militar y apogeo de occidente 1500-1800, Madrid, Alianza Editorial, S. A.

Pérez Alberti, Augusto (1986a): «El relieve», en María Pilar de Torres Luna (dir.), Geografía de Galicia. Volumen I: El medio fisico, A Coruña, Xuntanza Editorial, 19-197.

Pérez Alberti, Augusto (1986b): «La red fluvial. Su importancia en el modelado», en María Pilar de Torres Luna (dir.), Geografia de Galicia. Volumen I: El medio fisico, A Coruña, Xuntanza Editorial, 349-421.

Quirós, Juan Antonio / Sonia GobBato (2004): «Prospección y arqueología de la arquitectura», Arqueología Espacial, 24-5, 185-215.

SAntos Solla, Isabel / Xosé Manuel Santos Solla (1996): «O Baixo Miño», en Francisco Rodríguez Iglesias (ed.), Galicia Xeografía. Tomo XIX, Vales do Tambre e do Ulla, Rías Baixas pontevedresas e Baixo Miño, A Coruña, Hércules de Ediciones, 381-513.

Soraluce Blond, José R. (1985): Castillos y fortificaciones de Galicia: la arquitectura en los siglos XVI-XVIII, A Coruña, Fundación Pedro Barrié de la Maza.

SILVA, Luís Augusto Rebello da (1860): Historia de Portugal nos séculos XVII e XVIII, tomos I, II e III, Lisboa, Imprensa Nacional.

Vecoña, María (2006): Descubrir a historia. Plan director das fortalezas transfronteirizas do Baixo Miño, Santiago de Compostela, Xunta de Galicia, Consellería de Cultura e Deporte, Dirección Xeral de Patrimonio. 
Viveen, Willem / Jorge Sanjurjo-Sánchez / Ana Goy-Diz / Antonie Veldkamp / Jeroen M. Schoorl (2014): «Paleofloods and ancient fishing weirs in NW Iberian rivers», Quaternary Research, 82, 56-65.

Wheatley, David (1995): "Cumulative Viewshed Analysis: a GIS-based method for investigating intervisibility, and its archaeological application», en Gary Lock / Zoran Stancic (eds.), Archaeology and GIS: A European Perspective, London, Routlege, 171-185.

Wheatley, David / Mark Gillings (1999): «Vision, Perception and GIS: some notes on the development approaches to the study of archaeological visibility", en Gary Lock / Zoran Stancic (eds.), Beyond the map. Archaeology and Spatial Technologies, Amsterdam, IOS Press, 1-27.

Whittlesey, Stephanie M. (1997): «Archaeological landscapes: A methodological and theoretical discussion», en Stephanie Whittlesey / Richard Ciolek-Torrello / Jeffrey H. Altschul (eds.), Vanishing River: Landscapes and Lives of the Lower Verde Valley. The Lower Verde Valley Archaeological Project: Overview, Synthesis, and Conclusions, Tucson, SRI Press, 17-28. 
Os ríos forman parte do patrimonio natural de Galicia, sen eles non se recoñecería esta terra, a pesar das transformacións que tiveron, especialmente no século xx, coa construción de presas e encoros ou coa propia canalización en áreas urbanas e periurbanas.

Galicia dispón dun inventario do patrimonio cultural dos ríos (máis por consideracións hidráulicas que patrimoniais), que non é suficientemente coñecido e do que o Consello da Cultura Galega se fai eco nesta publicación, ao tratarse dun patrimonio ameazado.

Neste libro, o patrimonio cultural dos ríos en Galicia compleméntase coa análise do patrimonio doutros ríos como as beiras do Texo en Estremadura, o Pisuerga en Valladolid, o Eresma en Segovia, o Tyne en Newcastle, incluíndo as marxes, coma no caso das fortificacións do río Miño.

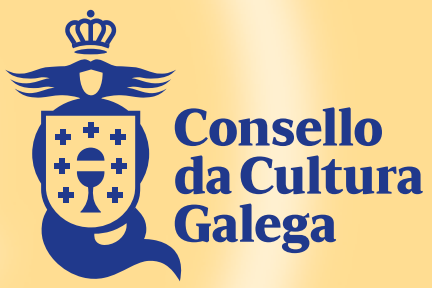

